UNIVERSIDADE DE SÃO PAULO

INSTITUTO DE GEOCIÊNCIAS

\title{
TECTONIC COMPARTIMENTATION OF AN AREA IN THE RIBEIRA BELT, BETWEEN ITAPEVA AND RIBEIRÃO BRANCO (SP): ITAIACOCA GROUP AND BAIRRO DOS PRESTES FORMATION
}

\section{ANNY JULIETH FORERO ORTEGA}

Orientador: Prof. Dr. Ginaldo Ademar da Cruz Campanha

Dissertação de Mestrado

№ 788

COMISSÃO JULGADORA

Dr. Ginaldo Ademar da Cruz Campanha

Dr. Leonardo Fadel Cury

Dr. Sérgio Wilians de Oliveira Rodrigues

Dr. Miguel Angelo Stipp Basei

SÃO PAULO

2018 
UNIVERSIDADE DE SÃO PAULO

INSTITUTO DE GEOCIÊNCIAS

\section{TECTONIC COMPARTIMENTATION OF AN AREA IN THE RIBEIRA BELT, BETWEEN ITAPEVA AND RIBEIRÃO BRANCO (SP): ITAIACOCA GROUP AND BAIRRO DOS PRESTES FORMATION}

Anny Julieth Forero Ortega

Dissertação apresentada ao Programa de PósGraduação em Geoquímica e Geotectônica do Instituto de Geociências da Universidade de São Paulo como requisito parcial para a obtenção do título de Mestre em Ciências.

Área de Concentração: Geotectônica

Orientador: Prof. Dr. Ginaldo Ademar da Cruz Campanha

São Paulo 
Autorizo a reprodução e divulgação total ou parcial deste trabalho, por qualquer meio convencional ou eletrônico, para fins de estudo e pesquisa, desde que citada a fonte.

Serviço de Biblioteca e Documentação do IGc/USP

Ficha catalográfica gerada automaticamente com dados fornecidos pelo(a) autor(a) via programa desenvolvido pela Seção Técnica de Informática do ICMC/USP

Bibliotecários responsáveis pela estrutura de catalogação da publicação: Sonia Regina Yole Guerra - CRB-8/4208 | Anderson de Santana - CRB-8/6658

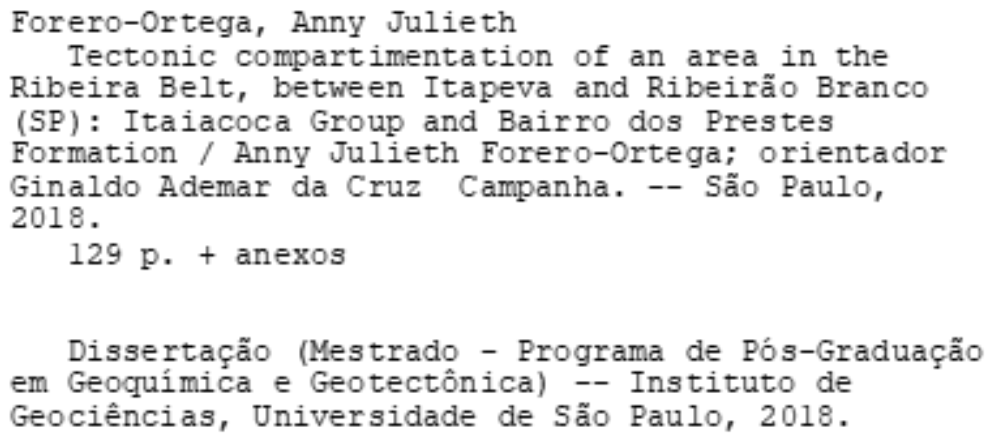

1. Geocronologia. 2. Geoquímica. 3.

Microestrutural. 4. Terreno Apiaí. I. Campanha,

Ginaldo Ademar da Cruz, orient. II. Título. 
E foste um difícil começo Afasta o que não conheço E quem vem de outro sonho feliz de cidade Aprende depressa a chamar-te de realidade Porque és o avesso do avesso do avesso do avesso

Sampa - Caetano Veloso

Vengo de una tierra Que le sobra corazón y voluntad Sueño con el día En que le sobre la razón para cantar

Confesión - Marta Gómez

Manos que tiemblan, manos que sudan Manos de tierra, maíz y sal Manos que tocan dejando el alma Manos de sangre, de viento y mar

Manos de mujeres - Marta Gómez

And though the seas are raging You will speak and tame them In You I find my rest You are in control

In control - Hillsong

To Anjobeli 


\section{AGRADECIMENTOS}

É incalculável e inestimável o crescimento acadêmico e pessoal que obtive em minha estadia no Brasil, este foi possível graças a muitas pessoas e instituições.

Agradeço ao Professor Doutor Ginaldo Campanha pela confiança, contínua orientação, inumeráveis discussões acadêmicas, liberdade científica no desenvolvimento do projeto e inesgotáveis correções que incluem um pouco de ortografía portuguesa. O senhor é um grande exemplo de pesquisador e ser humano!

Ao Professor Doutor Fredeiro Meira Faleiros, pelo apoio fornecido no desenvolvimento do projeto, por ter me ensinado a técnica de orientação cristalográfica de eixos-c do quartzo, e pelas sugestões e orientações nas análises microestruturaies e geoquímicas.

Aos professores Renato Paes, Renato de Moraes, Gergely Szabó, Rogério Guitarrari e Patricio Montecinos, pela orientação nas dúvidas que surgiram no desenvolvimento das técnicas usadas no projeto. E ao geólogo André Pires pela ajuda em campo.

Ao pessoal técnico e administrativo do Instituto de Geociências da USP, especialmente a Vasco Loios, Katherine Kutsumbos e Alexandre Blumer, pelo apoio dado.

À CAPES pela bolsa de mestrado, com a qual mantive os passos deste caminhar, assim como à FAPESP (2015/04487-7) pelo apoio nas jornadas de campo e análises realizadas.

Não posso deixar de agradecer as pessoas que fizeram mais linda minha moradia no Brasil, às Vilãs Dorgadas (Lari, Dori, Naza, Maria e Helena), Carlos, Cristiano, Julio, Nicholas e Renato, por abrir não só as portas das suas casas mas também dos seus corações. Ao Alberto e Ale, por me fazer parte da sua família, pelos inumeráveis jantares e momentos compartilhados, saibam que na Colômbia há uma casa lhes esperando. À Eliza, Ana e Amanda pelo meu lindo lar em São Paulo.

À minha "Colombia chiquita" (Ana, Astrid, Vero, Caro, Luzk, Maria Isabel, Dani, Paula, Cristian e Sebas) pelas lembrancinhas que ficaram semeadas no meu coração. Especialmente à Lina, por mais de nove anos de apoio, sinceridade, brigas e valiosa amizade, e ao Marcelo (meu amigo 33.3\% Japonês), pelas ininteligíveis discussões acadêmicas, sessões de terapia, acompanhamento em campo e pela amizade inapreciável.

E a Carlos Pachón, pelo amor, apoio, respeto e confiança desde o dia em que decidi fazer esta bela jornada. "Seja lá quem você se tornou, onde quer que você esteja no mundo, estou te mandando amor". 


\section{RESUMO}

A partir de mapeamento geológico, análises petrográficas, geoquímicas, geocronológicas e microestruturais em rochas metavulcânicas e metassedimentares, foi possível reconhecer duas sucessões de rochas metassedimentares - metavulcânicas de fácies xisto verde no sudoeste do Terreno Apiaí no cinturão Ribeira (entre Itapeva e Ribeirão Branco, SP): o Grupo Itaiacoca e a Formação Bairro dos Prestes. O Grupo Itaiacoca, datado pelo método U-Pb em zircão, apresentou idades neoproterozoicas entre 602,7 \pm 24 (metabasito) e 613,4 \pm 9,6 Ma (metatufo). É constituído por uma sucessão de metargilitos, filitos e quartzitos de granulação fina (Formação Água Nova), intercalados com metacalcários calcíticos e dolomíticos com estruturas estromatolíticas e pequenas camadas de tufo metavulcânico (Formação Bairro dos Campos) em contato transicional com rochas metabásicas, metadolomitos, e talco xisto e clorita xisto (Suíte Metabásica da Fazenda Velha) com quartzitos maciços (Formação Serra dos Macacos) sobrepondo todas as unidades. Com base na caracterização geoquímica, as metabásicas com assinaturas toleíticas e calci-alcalinas possuem padrões de manto tipo MORB com contribuição de componentes de subdução típicos de basaltos de bacias de retroarco. A Formação Bairro dos Prestes foi depositada entre $1761 \pm 14$ e $\sim 1800 \mathrm{Ma}$ (datada pelo metodo U-Pb SHRIMP em zircão de metariodacito e metavulcanossedimentar, respectivamente). A formação é composta por filitos, localmente com estruturas amigdaloides, em contato transicional com quartzitos de granulação fina a média, com camadas subordinadas de metaconglomerados e rohas metavulcânicas félsicas com assinatura calci-alcalina de alto $\mathrm{K}$.

$\mathrm{Na}$ área de estudo também estão presentes as rochas sedimentares paleozoicas do Grupo Itararé, os metarenitos quartzo-feldspáticos ediacaranos de granulação grossa da margem direita do rio Apiaí-Guaçu, a suite granítica ediacarana Três Córregos e o Complexo paleoproterozoico Apiaí Mirim. O Complexo Apiaí Miriam compreende paragnaisses e quartzitos micáceos de granulação média a grossa afetados por metamorfismo de fácies anfibolito, enquanto a Suite Granítica Três Córregos é constituída por monzogranitos porfiríticos e sienogranitos subordinados. A idade máxima de deposição obtida pelo método U-Pb LA-ICP-MS em zircões detríticos do Metarenito Apiaí-Guaçu foi de 588,4 \pm 1,8 Ma, o que permite correlacioná-la com as bacias da fase de transição do ciclo Brasiliano.

$\mathrm{O}$ arranjo estrutural compreende acamamento sedimentar $\left(\mathrm{S}_{\mathrm{o}}\right)$ e três foliações tectônicas $\left(\mathrm{S}_{\mathrm{n}}\right.$, $\mathrm{S}_{\mathrm{n}+1}$ e $\left.\mathrm{S}_{\mathrm{n}+2}\right)$. A foliação principal $\left(\mathrm{S}_{\mathrm{n}}\right)$ é caracterizada por xistosidade ou clivagem ardosiana, geralmente paralelas a $S_{o}$, apresentando direções NE-SW e mergulhos elevados. Os planos $S_{n}$ 
são deformados pelas clivagens de crenulação $S_{n+1}$ e $S_{n+2}$. A foliação $S_{n+1}$ está associada a dobras apertadas com planos axiais com direção NW desenvolvidas nos quartzitos, nas sequências metavulcanossedimentares e rochas pelíticas, enquanto a folição $S_{n+2}$ associa-se como dobras abertas com planos axiais com direção NE nos quartzitos e filitos. A área de estudo também é afetada por falhas NNW-SSE e NNE-SSW.

A análise microestrutural realizada em amostras da Formação Bairro dos Prestes e do Complexo Apiaí Mirim através de técnicas de Orientação Preferencial de Forma (OPF) e Orientação Cristalográfica Preferencial (OCP), indica uma forma oblata para o elipsoide de deformação finita com planos XY na direção NE-SW e X-direções com alta obliquidade, correlacionadas com os dados estruturais medidos em campo. As temperaturas de deformação calculadas a partir do ângulo de abertura das estruturas dos eixos-c variam de $531^{\circ} \mathrm{C}-593^{\circ} \mathrm{C}$ a $613^{\circ} \mathrm{C}-703^{\circ}$ C. Foram influenciadas pela presençia de água e pelos processos de dissolução, sendo por vezes maior que as temperaturas indicadas pelas associações minerais metamórficas (fácies xisto verde). As temperaturas de deformação também exibem um gradiente regional, com as temperaturas mais altas a sul e mais baixas a norte.

Um regime transpressivo com predominância de cisalhamento puro é sugerido com base na forma oblata e nas altas obliquidades dos eixos $\mathrm{X}$ do elipsoide de deformação finita.

O contexto geológico, os dados geocronológicos e geoquímicos sugerem que o Grupo Itaiacoca e a Formação Bairro dos Prestes podem ser correlacionados às formações Pirapora do Bom Jesus e Boturuna do Grupo São Roque. O Grupo Itaiacoca é interpretado como depositado em uma bacia de retroarco associada ao oceano Adamastor, provavelmente representando uma sutura ediacarana entre o Terreno Apiaí e o Craton Paranapanema.

Palavras chave: Grupo Itaiacoca, Formação Bairro dos Prestes, Terreno Apiaí, Geocronologia, Geoquímica, Microestrutural 


\begin{abstract}
Field geological mapping, petrographic, geochemical, geochronological and microestrutural analysis obtained from metavolcanic and metasedimentary rocks led to the recognition of two greenschist facies metasedimentary-metavolcanic rock successions in Southwest of Apiaí Terrane in Ribeira belt (between Itapeva and Ribeirão Branco, SP): the Itaiacoca Group and Bairro dos Prestes Formation. The Itaiacoca Group dated by U-Pb method in zircon yield Neoproterozoic ages of $602.7 \pm 24$ (metabasite) and 613.5 $\pm 9.6 \mathrm{Ma}$ (metatuff), it is constitute by a succession of metamudstone, phyllites and fine-grained quartzites (Água Nova Formation), intercalated with calcitic and dolomitic metalimestone with stromatolite structures and small beds of metatuff (Bairro dos Campos Formation) in transition contact with metabasites, metadolomites, talc schists and chlorite schists (Fazenda Velha Metabasic Suite), and massive quartzites (Serra dos Macacos Formation) overlapping all the units. Based on geochemistry characterization, the metabasites with tholeiitic and calc-alkaline signatures have patterns of MORB-type mantle with contribution of subduction components typically of back-arc basin basalts. The Bairro dos Prestes Formation was deposited between $1761 \pm 14$ and $\sim 1800 \mathrm{Ma}$ (Zircon SHRIMP U-Pb data of metarhyodacite and metavolcanosedimentary rock, respectively), it is composed of phyllites sometimes with amygdaloid structures in transitional contact with fine to medium grained-quartzites and restricted metaconglomerate and felsic metavolcanic rocks with high-K calc-alkaline signature.

In the study area is also present the flat-lying sedimentary rocks of the Paleozoic Itarare Group, the Ediacaran fine to coarse-grained feldspathic quartz metasandstones of the Apiaí-Guaçu metasandstone, the Três Córregos Granitic Suite and the Paleoproterozoic Apiaí Mirim Complex. The Apiaí Miriam Complex comprises paragneiss and medium to coarse grained micaceous quartzite affected by amphibolite facies metamorphism, while the Três Córregos Granitic Suite consists of porphyritic monzogranite and subordinate sienogranite. The maximum depositional age calculated by U-Pb ICPMS- LA of detrital zircons of the ApiaíGuaçu metasandstone was 588.4 \pm 1.8 Ma which allows to correlate it with the transition stage basins of the Brasiliano Cycle.

The structural arrangement comprises relict bedding $\left(\mathrm{S}_{\mathrm{o}}\right)$, and three tectonic foliations $\left(\mathrm{S}_{\mathrm{n}}, \mathrm{Sn}_{+1}\right.$ and $\left.\mathrm{Sn}_{+2}\right)$. The main foliation $\left(\mathrm{S}_{\mathrm{n}}\right)$ is characterized as a schistosity or slaty cleavage, generally parallel to $S_{o}$, presenting NE-SW strikes and steep dips, and it is deformed by $S_{n+1}$ and $S_{n+2}$ crenulation cleavages. The $\mathrm{S}_{\mathrm{n}+1}$ is associated with tight folds with NW axial-planes in quartzite,
\end{abstract}


metavolcanosedimentary and pelitic sequence, and the $S_{n+2}$ with open folds with NE axialplanes in quartzite and phyllite rocks. The study area is also affected by NNW-SSE and NNESSW faults.

The microstructural analysis was performed in samples of Bairro dos Prestes Formation and Apiaí Mirim Complex through Shape Preferential Orientation (SPO) and Lattice Preferred Orientation (LPO) techniques, determinate an oblate shape for the finite strain ellipsoid with XY planes with NE-SW strike and X-directions with high rake, correlated with the structural data measured in field. The deformation temperatures calculated from opening-angle of c-axis structures vary from $531^{\circ} \mathrm{C}-593^{\circ} \mathrm{C}$ to $613^{\circ} \mathrm{C}-703^{\circ} \mathrm{C}$, they were influenced by water weakling and solution-transfer process, being sometimes higher that the temperatures indicated by the metamorphic mineral assemblages (facies greenschists). The deformation temperatures also display a spatial gradient, in the south the highest temperatures are present, while in the north, the lowest temperatures were calculated.

A transpressive regime with predominance of pure shear is suggested based on the oblate shape and high rake $\mathrm{X}$ axis of the finite strain ellipsoid.

The geological context, geochronological and geochemical data suggest that the Itaiacoca Group and Bairro dos Prestes Formation can be correlated with Pirapora do Bom Jesus and Boturuna formations of São Roque Group. The Itaiacoca Group is interpreted as arc-back-arc basin system is associated with the large Adamastor Ocean, and probably represents an Ediacaran suture zone between the Apiaí Terrane and the Paranapanema Craton.

Keywords: Itaiacoca Group, Bairro dos Prestes Formation, Apiaí Terrane, Geochronology, Geochemistry, Microstructural. 
TABLE OF CONTENTS

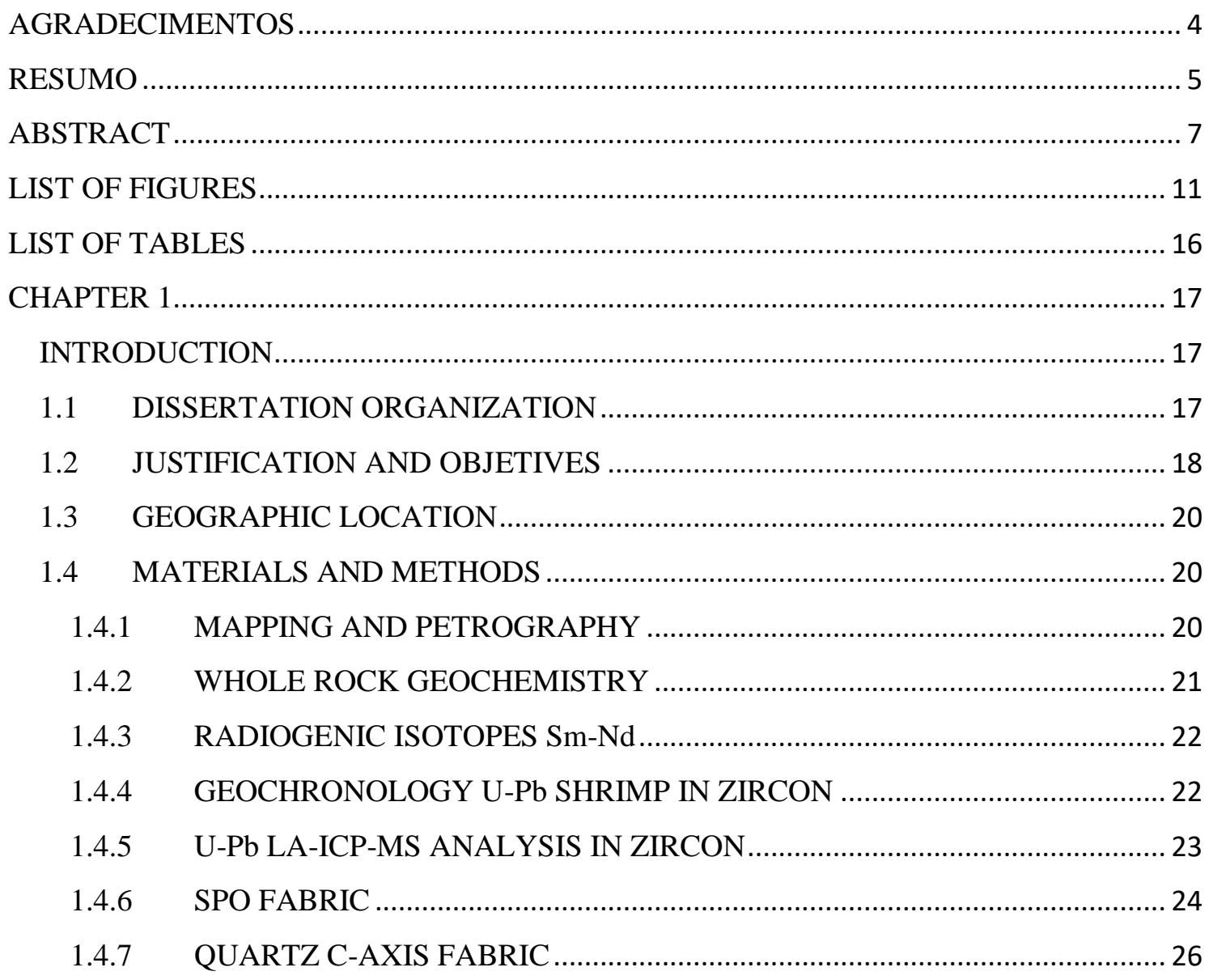

CHAPTER 2. Geological map of Itaiacoca Group and Bairro dos Prestes Formation, between Itapeva

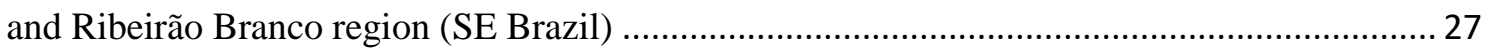

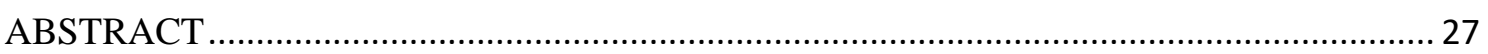

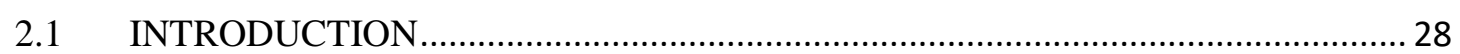

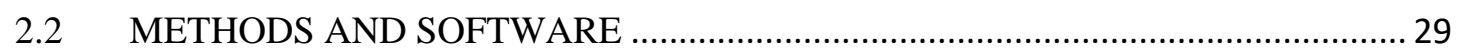

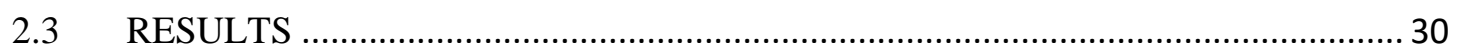

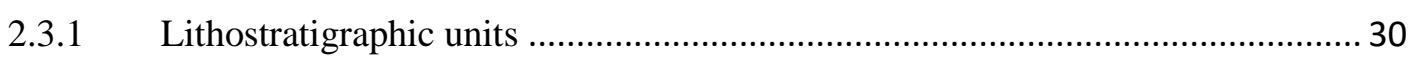

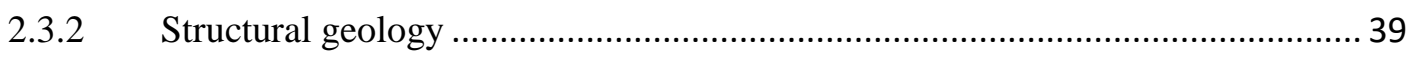

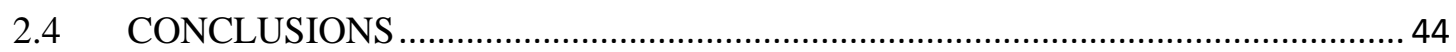

CHAPTER 3. Ediacaran (570-615 Ma) back-arc basin basaltic volcanism in the Itaiacoca Group, Ribeira Belt, Brazil: a remnant of the Adamastor Ocean ............................................................ 45

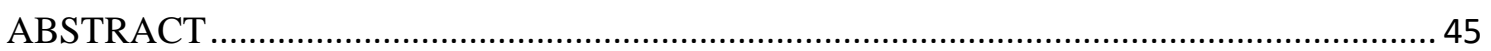

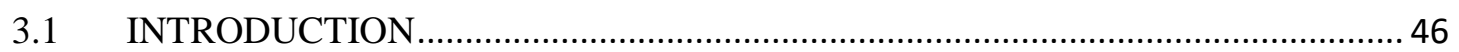

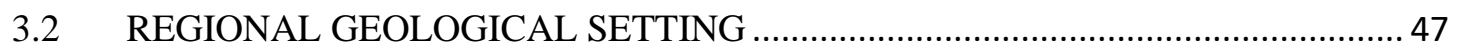

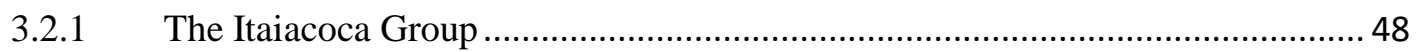

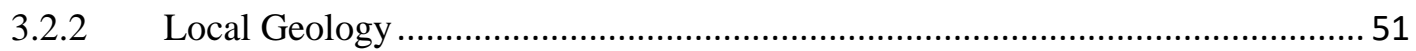




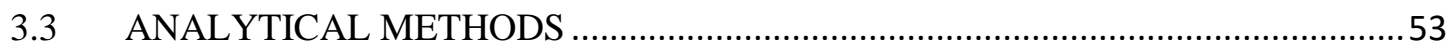

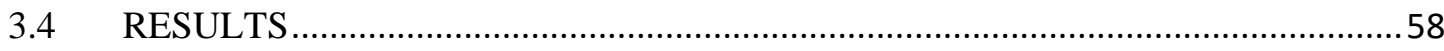

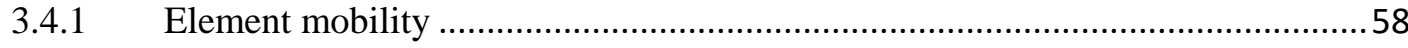

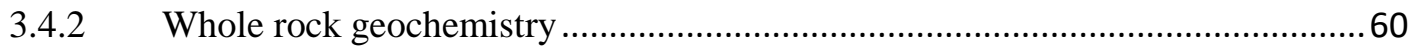

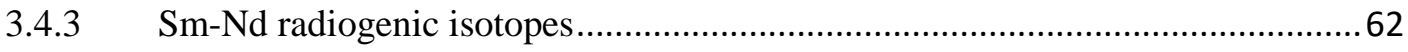

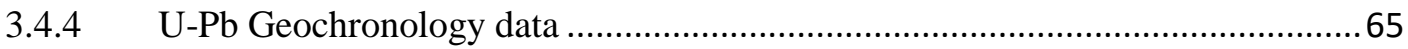

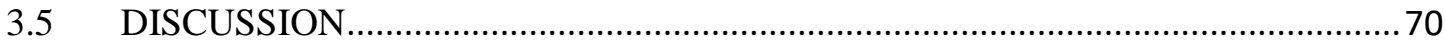

3.5.1 Tectonic setting of basic magmatism ............................................................. 70

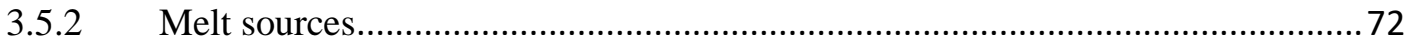

3.5.3 Ages of igneous crystallization, depositional and hydrothermal events ..............73

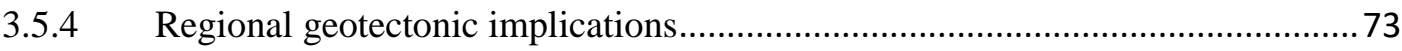

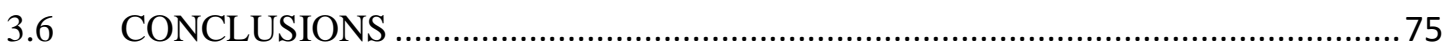

CHAPTER 4. Pure shear-dominated transpression in the southern Ribeira Belt, Brazil: finite strain and quartz c-axis fabric constraints from the Bairro dos Prestes Formation .......................................83

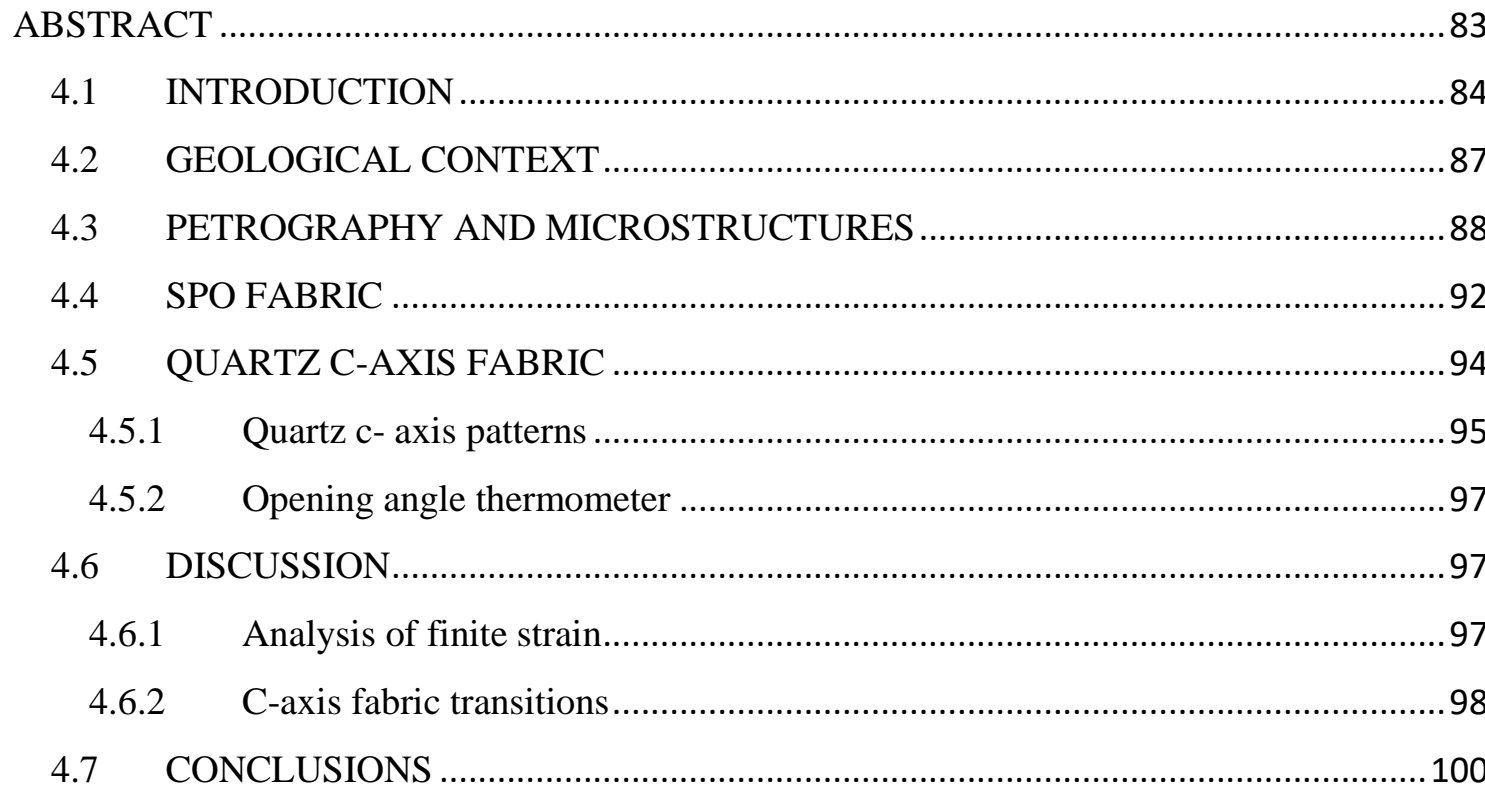

CHAPTER 5. New occurrence of a Late Ediacaran metasandstone deposit located on the Apiaí-Guaçu

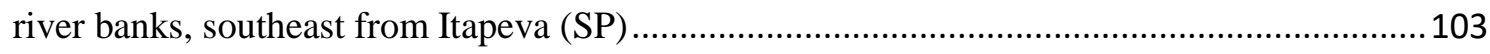

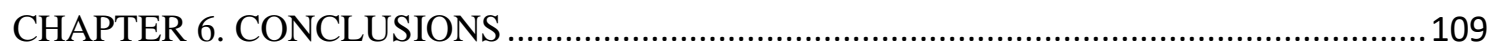

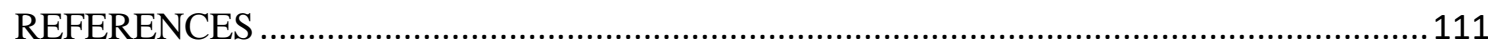

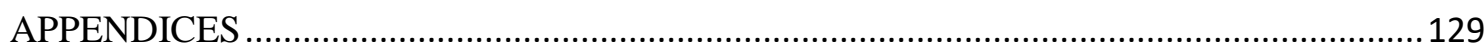

APPENDIX 1. Map of outcrop points

APPENDIX 2. Geological map

APPENDIX 3. Geological cross-sections 


\section{LIST OF FIGURES}

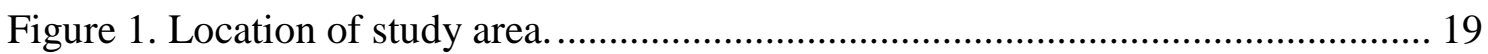

Figure 2. 1. Simplified geotectonic map of the Southwestern portion of the Ribeira Belt with location of study area Figure 2.2. (From Campanha et al., 2015) ......................... 28

Figure 2. 2. Thin-section of Jurassic-Cretaceous basic rock in cross-polarised light. ... 31

Figure 2. 3. Outcrops of sedimentary rocks of Paraná basin (Itararé Group), in which is possible to identify: (a) cross bedding of fine sandstone, (b) syn-sedimentary fold of the layers of reddish sandstone and (c) ripple marks developed in coarse sandstone... 32

Figure 2. 4. Apiaí-Guaçu metasandstone with primary structures (bedding), recognizable by the color alternation of the laminations.

Figure 2. 5. Thin section of Três Córregos granite sample: (a) Plane-polarised and (b) crosspolarised light. 33

Figure 2. 6. Outcrop of quartzite from the Serra dos Macacos Formation 33

Figure 2. 7. Thin section of metabasic rock from Fazenda Velha Metabasic Suite in which are possible to observe: reliquiar subophitic texture under plane-polarised (a) and crosspolarised light (b), pseudomorphs of with chemical zoning under plane-polarised (c) and cross-polarised light (d). 34

Figure 2. 8. Outcrop of Água Nova Formation, phyllites overlained in a discordant contact by the flat sedimentary rocks of the Itarare Group. 35

Figure 2. 9. Cross polarized light optical photomicrographs of tuff intercalation, Bairro dos Campos Formation 36

Figure 2. 10. Photomicrographies in plane-polarised light of (a) quartz-biotite phyllite and (b) quartz-feldspar-biotite phyllite, Bairro dos Prestes Formation. 36

Figure 2. 11. Abandoned quartzite quarry, Bairro dos Prestes Formation. 37

Figure 2. 12. Thin section of a metarhyodacite sample, Bairro dos Prestes Formation: (a) Plane-polarised and (b) cross-polarised light.

Figure 2. 13. Outcrop of metaconglomerate from Bairro dos Prestes Formation showing (a) parallel to chaotic orientation of the black phyllites clasts and (b) metavolcanosedimentary pebbles 38

Figure 2. 14. Thin section of paragneiss sample, Apiaí-Mirim Complex: (a) Plane-polarised and (b) cross-polarised light. 
Figure 2. 15. Some of the sedimentary structures in Itaiacoca Group: (a) bedding in the metamudstone rock.

Figure 2. 16. Stereographic projection of the poles concentration of Sn (Schmidt-Lambert projection lower hemisphere, mean plane in dip direction / dip). 40

Figure 2. 17. Stereographic projection of the poles concentration of Sn+1 (Schmidt-Lambert projection lower hemisphere, mean plane in dip direction / dip). 40

Figure 2. 18. Stereographic projection of the poles concentration of Sn+2 (Schmidt-Lambert projection lower hemisphere, mean plane in dip direction / dip). 41

Figure 2. 19. Examples of macro and micro folding of the $S n$ planes from the $D_{n+1}$ deformational event and generation of $S_{n+1}$ cleavage: (a) Amygdales in a metavolcanosedimentary rock stretched parallel to the $S_{n}$ planes. (b) Tight fold deforming the $S_{n}$ and with a axial-plane $S_{n+1}$. (c) Tight fold with subhorizontal axis in quartzite with axial plane defined by $S_{n+1}$. (d) Open fold with axial plane delineating by $S_{n+2}$. (e) Tight fold with axial plane subvertical and subhorizontal axis affecting the $S_{\mathrm{n}}$ and with a axialplane $S_{n+1}$ and (f) open folds in pelitic sequence with axial plane $S_{n+2}$ 42

Figure 2. 20. Outcrop of gray phyllite located some meters of a NE-SW fault trace, showing dextral shear sense from kinematic indicators as the S-C structures and synthetic microfaults present in the quartz vein 43

Figure 2. 21. Dextral shear sense determinate from: (a) microfaults in quartz crystals and (b) $\mathrm{C}^{\prime}$-type shear bands in quartzites and of sinistral movement suggested by $\sigma$ porphyroclasts developed in: (c) Quartz crystal and (d) aggregates of quartz and biotite.

Figure 3. 1. Simplified geotectonic map of the Southwestern portion of the Ribeira Belt with location of study area Figure 3.2. (From Campanha et al., 2015). 47

Figure 3. 2. Geological map of the studied area. Itararé Group (C2P1i), Apiaí-Guaçu metasandstone ( $\varnothing 1 \mathrm{ag}$ ), Ribeirão Branco granite (NP3tcrb); Itaiacoca Group: Serra dos Macacos Formation (NP 3itsm), Fazenda Velha Metabasic Suite (NP 3itfv), Água Nova Formation (NP3itan) and Bairro dos Campos Formation (NP3itbc), Bairro dos Prestes Formation: phyllite (PP3bdpr) with intercalations of quartzites (PP3bdq) and Apiaí Mirim Complex (PP3amp). The analyzed samples are georeferenced to Universal Transverse Mercator coordinate system (WGS 84 Horizontal Datum, 22S zone). 50

Figure 3. 3. Photomicrography under cross and plane polarized light optical of (a) flow and brechoid textures of the metatuff rocks and (b) metabasite sample showing pseudomorphs of pyroxene. 51

Figure 3. 4. Thin sections of phyllite exhibit (a) millimetric vacuoles and (b) metarhyodacite sample (under plane-polarised light). 
Figure 3. 5. Diagrams of the ratios of molecular proportions for metabasites from the Fazenda Velha Metabasic Suite of the Itaiacoca Group. In red, the CA1 sample.

Figure 3. 6. Binary plots of $\mathrm{Nb}$ vs. $\mathrm{Rb}, \mathrm{U}, \mathrm{K} 2 \mathrm{O}, \mathrm{Sm}, \mathrm{Al} 2 \mathrm{O} 3, \mathrm{Ta}, \mathrm{Sr}, \mathrm{TiO} 2, \mathrm{Ba}, \mathrm{La}, \mathrm{Zr}, \mathrm{Y}$, Th, $\mathrm{Ce}, \mathrm{Hf}$ and $\mathrm{Yb}$ from metabasites. In red, the CA1 sample. 58

Figure 3. 7. Diagrams for the classification of metabasites from the Fazenda Velha Metabasic Suite of the Itaiacoca Group and metarhyodacite of Bairro dos Prestes Formation. (a) $\mathrm{Nb} / \mathrm{Y}-\mathrm{Zr} / \mathrm{TiO} 2$ plot (Winchester and Floyd, 1977), (b) AFM plot (Irvine and Barragar, 1971), (c) Co-Th plot (Hastie et al., 2007) and (d) A/CNK-A/NK diagram (Shand, 1943). In red and yellow, the CA1 and CA39 sample, respectively. 59

Figure 3. 8. (a) Rare earth element and (b) spidergrams from metabasites of Itaiacoca Group and metarhyodacite of Bairro dos Prestes Formation. Normalizing values with respect to Boynton (1984) for chondrite and Sun and McDonough (1989) for MORB. 61

Figure 3. 9. Sm-Nd isochrone of the mebasites samples of the Fazenda Velha Metabasic Suite of the Itaiacoca Group. 62

Figure 3. 10. CL images of zircon crystals from (a) metabasite - F135, (b) metabasite - P13 and (c) metatuff - CA13 samples of Itaiacoca Group and (d) metavolcanosedimentary CA38 and (e) metarhyodacite -CA39 rock of Bairro dos Prestes Formation. In the pictures are indicated the spot analyses number and the ${ }^{206} \mathrm{~Pb} /{ }^{238} \mathrm{U}$ age for $<1300 \mathrm{Ma}$ and ${ }^{206} \mathrm{~Pb} /{ }^{207} \mathrm{~Pb}$ age for $>1300 \mathrm{Ma}$. 65

Figure 3. 11. Concordia diagram of: (a) ${ }^{207} \mathrm{~Pb} /{ }^{206} \mathrm{U}$ versus ${ }^{238} \mathrm{U} /{ }^{206} \mathrm{~Pb}$ of $\mathrm{F} 135$ sample with the concordia age and weighted average age for the first and second group, respectively (b) ${ }^{206} \mathrm{~Pb} /{ }^{238} \mathrm{U}$ versus ${ }^{207} \mathrm{~Pb} /{ }^{235} \mathrm{~Pb}$ of $\mathrm{P} 13$ metabasite with probability density plot of the data, (c) ${ }^{206} \mathrm{~Pb} /{ }^{238} \mathrm{U}$ versus ${ }^{207} \mathrm{~Pb} /{ }^{235} \mathrm{~Pb}$ of CA13 metatuff, (d) ${ }^{206} \mathrm{~Pb} /{ }^{238} \mathrm{U}$ versus ${ }^{207} \mathrm{~Pb} /{ }^{235} \mathrm{~Pb}$ of CA38 metavolcanosedimentary with probability density plot of the chosen spots and (e) ${ }^{207} \mathrm{~Pb} /{ }^{206} \mathrm{U}$ versus ${ }^{238} \mathrm{U} /{ }^{206} \mathrm{~Pb}$ of CA39 metarhyodacite rock. 68

Figure 3. 12. Tectonic discrimination diagrams of metabasites. (a) $\mathrm{Zr} / 4-2 \mathrm{Nb}-\mathrm{Y}$ plot (Meschede, 1986), (b) Zr-Zr/Y plot (Pearce and Norry, 1979), (c) Nb/Yb-Th/Yb plot (Pearce, 2008) and (d) V(ppm)/Ti(ppm) plot (Shervais, 1982). In red, the CA1 sample.

Figure 3. 13. Tectonomagmatic discrimination diagrams of metarhyodacite rocks. (a) Ta (ppm) vs $\mathrm{Yb}(\mathrm{ppm})$ of Pearce et al. (1984), (b) Th/Hf - Ta/Hf plots of Schandle and Gorton (2002), and (c) Y-Nb-3*Ga triangular diagrams of Eby (1992). 71

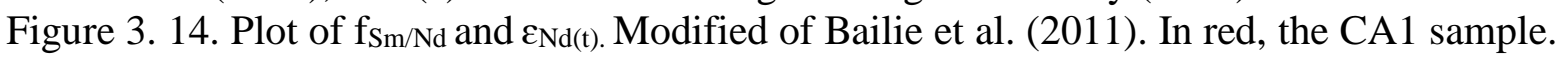
72

Figure 4. 1. Simplified geotectonic map of the Southern and central portions of the Ribeira Belt with location of study area Figure 4.2. (From Campanha et al., 2015).... 84 
Figure 4. 2. Geological map of the studied area. Itararé Group (C2P1i), Apiaí-Guaçu metasandstone ( $₫ 1 \mathrm{ag})$, Ribeirão Branco granite (NP3tcrb); Itaiacoca Group: Serra dos Macacos formation (NP 3itsm), Fazenda Velha Metabasic Suit (NP 3itfv), Água Nova Formation (NP3itan) and Bairro dos Campos Formation (NP3itbc), Bairro dos Prestes Formation: phyllite (MP1bdpr) with intercalations of quartzites (MP1bdq), and Apiaí Mirim Complex (PP3amp). (Taken from Forero-Ortega et al., 2018). Structural attitudes in black were measured in the field, and in white calculated by SPO. 86

Figure 4. 3. Stereographic projection of the poles concentration of (a) $S_{n}$, (b) $S_{n+1}$ and (c) $S_{n+2}$ planes (Schmidt-Lambert projection lower hemisphere, mean plane in dip direction / dip).

Figure 4.4. P-T diagram for paragneiss sample with grey pentagon representing the stability field delimited by the reactions two and eight and red line corresponding to the deformation temperature calculated from quartz c-axis fabric opening-angles. Adapted from Spear et al. (1999). 89

Figure 4. 5. Cross-polarized light optical photomicrographs of dynamic recrystallization mechanisms of quartz aggregates: (a) Sample CA09b: quartz and feldspar porphyroclasts with irregular and elongated shape alternating with fine matrix of sericite and quartz microcrystals. (b) Sample CA10c: quartz porphyroclasts with irregular shape and strain shadow of recrystallized quartz with lobate boundaries. (c) Sample CA39.2: plagioclase porphyroclasts with strain shadow of straight recrystallized quartz and fine matrix of mica and feldspar microcrystals. (d) Sample CA74c: quartz porphyroclasts with cuspate shape and boundaries with mica and lobate recrystallized material. (e) Sample CA85: quartz porphyroclasts with deformation lamellae and polygonal shapes of recrystallized quartz. (f) Sample CA125: quartz porphyroclasts with lobated boundaries and recrystallized quartz with pinning structure. (g) Sample P33: quartz porphyroclasts with straight boundaries and with pinning and window structures. (h) Cross polarized light optical photomicrographs under compensator plate showing optic continuity of the quartz porphyroclasts with ondulose extinction and recrystallized quartz. (i) Cross-polarized light optical photomicrographs of vein in the plagioclase porphyroclast filled with previously dissolved silica. (j) Inclusion trails parallel and perpendicular to quartz porphyroclast boundaries highlighting the host grain growth Photomicrography under cross polarized light of $(\mathrm{k})$ paragneiss displaying (l) fibrolite and feldspar as peritectic minerals and $(\mathrm{m})$ quartz, potassic feldspar and plagioclase constituting the leucosome fraction. 91

Figure 4. 6. Principal direction orientations of the strain ellipsoid (X, Y and $\mathrm{Z}$ axes in red, green and blue respectively) and shape parameters. Jelinek (1981) parameters are $\mathrm{P}^{\prime}=\exp [2((\operatorname{lnk} 1 \mathrm{k} \text { mean }+\operatorname{lnk} 2 \mathrm{k} \text { mean }+\operatorname{lnk} 3 \mathrm{k} \text { mean }))]^{1 / 2}, \mathrm{~T}=\left[2\left(\ln \mathrm{K}_{2}-\ln \mathrm{K}_{3}\right) /\left(\ln \mathrm{K}_{1}-\ln \mathrm{K}_{3}\right)\right]-$ 1 , with $\mathrm{k}_{\text {mean }}=\mathrm{k} 1+\mathrm{k} 2+\mathrm{k} 33$. The $\mathrm{K}_{1}$ axis represents the lineation while $\mathrm{K}_{3}$ is the pole of the foliation (with principal axes $\mathrm{K}_{1}>\mathrm{K}_{2}>\mathrm{K}_{3}$ ). 93

Figure 4. 7. Flinn diagram with the $\mathrm{X}, \mathrm{Y}, \mathrm{Z}$ axes of the strain ellipsoid determinate by SPO analysis.

Figure 4. 8. Lower hemisphere equal-area projections of optically measured quartz c-axis fabrics; foliation oriented left-right and vertical and stretching lineation horizontal; it is 
also presented the opening-angles (OA) and the respective calculated deformation temperatures.

Figure 5. 1. Concordia diagram of ${ }^{206} \mathrm{~Pb} /{ }^{238} \mathrm{U}$ versus ${ }^{207} \mathrm{~Pb} /{ }^{235} \mathrm{~Pb}$ of $\mathrm{CA} 75$ metasandstone. 104

Figure 5. 2. CL images of zircon crystals from metasandstone - CA75. 


\section{LIST OF TABLES}

Table 3. 1. Studied samples in the geochemical analysis.

Table 3. 2. Major and trace element geochemical data for metabasites from the Fazenda Velha Metabasic Suite of the Itaiacoca Group and metarhyodacite of Bairro dos Prestes Formation. Oxides in wt.\%, trace elements in ppm and geographical coordinates in decimal degrees (WGS-84 datum).... 55

Table 3. 3. Sm/Nd analytical results for metabasites from the Fazenda Velha Metabasic Suite of the Itaiacoca Group and metarhyodacite of Bairro dos Prestes Formation. 57

Table 4. 1. Mineralogy, deformation mechanism (Subgrain rotation SGR, grain boundary migration GBM and pressure solution PS), opening angle of quartz c-axis structures and the calculated deformation temperature. 88

Table 4. 2. Strain ellipsoids obtained by the inertia tensor method. Orientation data of plane $\mathrm{XY}$ and main axes in strike and dip (right-hand rule), $\mathrm{X} / \mathrm{Z}$ maximum deformation, $\mathrm{T}$ shape and $\mathrm{K}$ style of strain parameter (with $\mathrm{K}=(\mathrm{X} / \mathrm{Y}-1)(\mathrm{Y} / \mathrm{Z}-1)$ ), and $\sqrt{\mathrm{F}} \%$ incompatibility index.

Table $S_{1}$. Analytical SHRIMP results for metabasite sample F135 of the Fazenda Velha Metabasic Suite of the Itaiacoca Group.

Table $\mathrm{S}_{2}$. Analytical SHRIMP results for metabasite sample P13 of the Fazenda Velha Metabasic Suite of the Itaiacoca Group. 78

Table $S_{3}$. Analytical SHRIMP results for metatuff sample CA13 of the Bairro dos Campos Formation of the Itaiacoca Group. 79

Table $\mathrm{S}_{4}$. U-Pb isotopic data results for metavolcanosedimentar sample CA38 of the Bairro dos Prestes Formation. 80

Table $\mathrm{S}_{5}$. U-Pb isotopic data results for metarhyodacite sample CA39 of the Bairro dos Prestes Formation

Table $\mathrm{S}_{6}$. Analytical LA-ICP-MS results for metasandstone CA75 of the Apiaí-Guaçu metasandstone. 


\section{CHAPTER 1}

\section{INTRODUCTION}

The Proterozoic metasedimentary and metavolcanic successions present in the South of Ribeira belt, in São Paulo and Paraná states, have been subject to a continuous debate about their ages, correlations, tectonic and paleogeographic environments (Soares, 1987; Campanha et al., 1987; Reis Neto, 1994; Campanha and Sadowski, 1999; Prazeres Filho, 2005; Salazar et al., 2013; Henrique-Pinto et al., 2015; Siga et al., 2009, 2011a, 2011b, 2011c; Faleiros et al., 2010, 2011a, 2016).

Especially the discussions about the tectonic and paleoenvironmental meaning of the Itaiacoca Group (Almeida, 1956; Petri and Suguiu, 1969; Souza, 1990, 1992) and its associated volcanic sucessions, like that in the Abapã region, Paraná state (Trein et al., 1985; Reis Neto, 1994; Siga Jr. et al., 2003, 2009) have occupied much of the technical literature about the region.

In the São Paulo state on the northern continuity Itaiacoca Group, metasedimentarymetavolcanic successions have been recognized in the Itapeva and Ribeirão Branco region by regional geological mapping (Theodorovicz et al., 1986, 1988; Theodorovicz and Câmara, 1988; Takahashi et al., 1984) but until the moment poorly characterized in their petrographic, structural, geochemical and geochronological aspects.

This contribution characterizes the metasedimentary-metavolcanic rock units present between Itapeva and Ribeirao Branco (SP), from 1:25,000 geological mapping-scaled, petrographic and

microstructural descriptions, and geochemical and geochronological analyses. It is also proposed the dismemberment of Bairro dos Prestes Formation from the Itaiacoca Group based on volcanic ages, and include a discussion of the possible tectonic settings and stratigraphic correlations of the units. The results, presented in the form of manuscripts of scientific papers, intended to be submitted to indexed journals.

\subsection{DISSERTATION ORGANIZATION}

This dissertation is organized in six chapters and three appendices. The current Chapter 1 introduces the problem, objectives, the area and a general view of the materials and methods. The chapters 2 to 5 are presented in the format of manuscripts of papers to be submitted to 
scientific journals. The chapter 6 summarizes the main conclusions. The appendix 1 present the map of outcrop points, the appendix 2 the geological map and the appendix 3 the geological cross-sections.

The Chapter 2 is about the 1:25,000 geological cartography done, the methods and software used, the lithostratigraphic units recognized and the structural arrangement present in the area. It is reported in the manuscript denominated "Geological map of Itaiacoca Group and Bairro dos Prestes Formation, between Itapeva and Ribeirão Branco region (SE Brazil)”.

The Chapter 3 includes the article "Ediacaran (570-615 Ma) back-arc basin basaltic volcanism in the Itaiacoca Group, Ribeira Belt, Brazil: a remnant of the Adamastor Ocean”. It deals with field, petrographic, geochemical and geochronological characterization of the Itaiacoca Group and Bairro dos Prestes Formation and the interpretation of their tectonic environment, depositional and volcanic ages.

The Chapter 4 presents the quantification and characterization of SPO and LPO microstructure fabrics, the deformation temperatures calculated from LPO opening-angles and their comparison withstructural data measured in field and temperatures indicated by metamorphic mineral assemblages. They are described in the article "Pure shear-dominated transpression in the southern Ribeira Belt, Brazil: finite strain and quartz c-axis fabric constraints from the Bairro dos Prestes Formation".

The chapter 5 corresponds to a short note of an Upper Neoproterozoic metarenite deposit located on the Apiaí-Guaçu river banks, in which the geochronologic data and petrographic description of the unit is stated.

\subsection{JUSTIFICATION AND OBJETIVES}

The Itaiacoca Group presents uncertainties in its stratigraphic organization, structural geology, age and sedimentation environment, which must be studied from local studies, that allow a better characterization of the units. With the current study, we intend:

- Identify and describe macro and microscopically the lithostratigraphic units and structures present in the study area. 

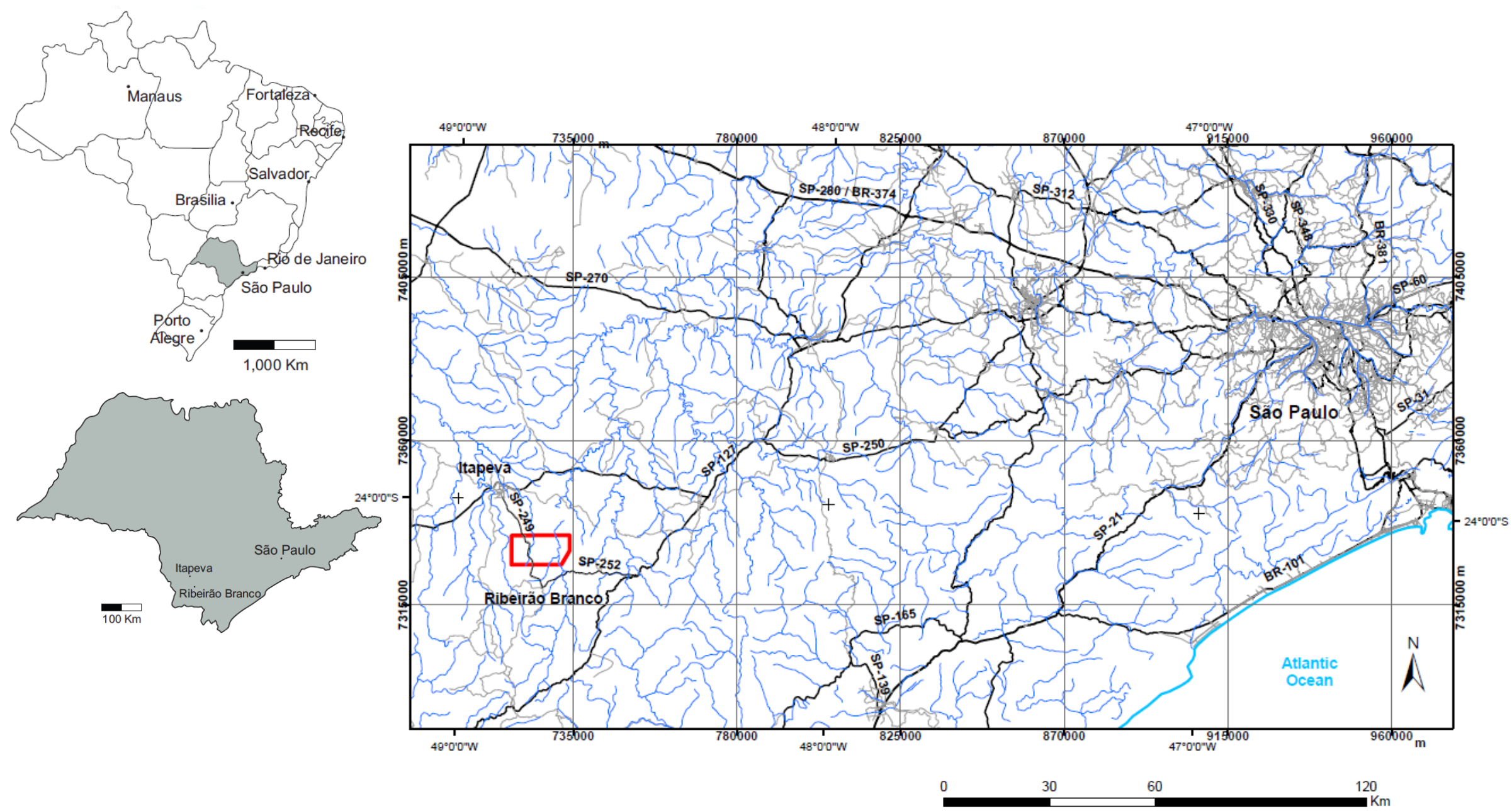

Figure 1. Location of study area. 
- Perform a microstructural analysis through the description and interpretation of deformation mechanisms and Shape Preferential Orientation (SPO) and Lattice Preferred Orientation (LPO) microstructures fabrics of the rocks.

- Interpret the tectonic setting and melt sources of the metavolcanic rocks from geochemistry analyses in bulk rock and $\mathrm{Sm}$ and $\mathrm{Nd}$ isotopic system

- Determine the age of the metasedimentary-metavolcanic rock successions using the U$\mathrm{Pb}$ method (SHRIMP and LA-ICP-MS) in zircon.

- Establish the regional geotectonic implications of the units through stratigraphic and geochronological correlations.

\subsection{GEOGRAPHIC LOCATION}

The study area is located in São Paulo state, approximately $240 \mathrm{~km}$ from the São Paulo city (Figure 1). Its limits are given by the UTM coordinates $\mathrm{x}=178,000-734,000 \mathrm{~m}$ and $\mathrm{y}=7,326,000-7,334,000 \mathrm{~m}$ (Universal Transverse Mercator projection, WGS 84 Horizontal Datum, 22S zone). It is covered by part of the Ribeirão Branco (22-X-B-II-1) and Guapiara (22X-B-II-2) 1:50,000 topographic sheets.

\subsection{MATERIALS AND METHODS}

The methods used for the project development include geological mapping and sample collection, petrographic, whole rock geochemistry, Sm-Nd isotopic, U-Pb SHRIMP and LAICP-MS geochronology in zircon analyzes, and structural microanalysis by SPO and LPO techniques.

\subsubsection{MAPPING AND PETROGRAPHY}

The cartography work was made in four steps of 25 days in total, in which 139 outcrop sites were registered with geological and structural information as well, photographic record and inventory of samples collected for posterior analyses. The field tracks were done preferably orthogonally to the regional structural trend but due the scarcity of outcrops in some areas all roads and paths were covered. In field, geometric and kinematic analyzes were performed on the structures when was possible, and for the collected samples (76 in total) mostly oriented, 
their mineral composition, texture and structure were described. The procedure of map digitalization, which is based on the geological information taken in field is described in the chapter 2 .

The petrographic analyses were carried out through 65 thin sections, 31 of them oriented (cut parallel to the lineation and perpendicular to the cleavage plane), they were elaborated in the thin section laboratory of the Institute of Geosciences of the University of São Paulo (USP). The thin sections were observed through the Zeiss Axioplan El-Einsatz petrographic microscope of the microscopy laboratory for postgraduate student of the Institute of Geosciences, with the purpose of classify petrographically the rocks based on the mineral composition and describe textures, recrystallization mechanisms, microstructures and kinematic indicators present in the samples.

\subsubsection{WHOLE ROCK GEOCHEMISTRY}

The interpretation of rock petrogenesis were made using petrographic data and tools geochemistry as radiogenic and stable isotope compositions and major elements (reported in term of wt. \% oxides) and trace concentrations, that, plotted in classification and discrimination diagrams, help to understand the compositional variation, origin, tectonic setting, geological variations record and evolution of igneous system (Best, 2003; Wilson, 2007).

The chemical analyses of fourteen samples previously crushed and sprayed with an agate mill in the laboratory of samples preparation of the Institute of Geosciences (USP), and the analyses were performed at Activation Laboratories Ltda (Actlabs, Canada). The major and minor oxides were determinate by lithium metaborate/tetraborate fusion (ICP/WRA), in which the samples were mixture with lithium metaborate/ lithium tetraborate solution and subsequently fused in an induction furnace. The molten melt was aggregate in 5\% nitric acid until obtained a homogeneous mixture, which through Thermo Jarrell-Ash ENVIRO II ICP or a Varian Vista 735 ICP, the principal oxides were read. The trace elements were deduced by inductively coupled plasma mass spectrometry (ICP-MS). For dilution process was used the same methodology for principal oxides, but they were analyzed by Perkin Elmer Sciex ELAN 6000, 6100 or 9000 ICP/MS. The detection limit of each element can be find in actlabs website.

The analytical data were processed in the GCDkit program version 4.1 (Janousek et al., 2006, 2011), in which molecular reason, binary plot, classification (Winchester and Floyd, 1977; A/CNK-A/NK; Irvine and Barragar, 1971 and Hastie et al.,2007), rare earth element 
(normalized to chondrite) (Boynton, 1984), spidergrams (compared to MORB) (Sun and McDonough, 1989) and discrimination diagrams (Meschede, 1986; Pearce and Norry, 1979; Pearce, 2008; Pearce et al., 1984; Th/Hf - Ta/Hf plots of Schandl and Gorton, 2002 and Y-Nb$3 *$ Ga triangular diagrams of Eby, 1992) were generated.

\subsubsection{RADIOGENIC ISOTOPES Sm-Nd}

The unstable isotopes are excellent petrogenetic tracer given their contrast chemical behavior and mobility in the evolution of magma process, especially in mantle-basaltic systems, in which the most incompatible element is concentrated in partial melt and solidify in crust, while, the compatible remains in the magma source (Best, 2003). The Sm and Nd isotopes present similar ionic radii, characterizing a system immobile and resists to posterior alteration or hydrotermal events. The initial ratio $\left({ }^{143} \mathrm{Nd} /{ }^{144} \mathrm{Nd}\right)_{0}$, is used as petrogenetic indicator, it displays higher ratios in conditions with light REE-depleted and lower ratios in rocks present in the continental crust with low Sm/Nd ratios (Best, 2003). The ${ }^{143} \mathrm{Nd} /{ }^{144} \mathrm{Nd}$ can also be compared with CHUR (DePaolo and Wasserburg, 1976), through the $\varepsilon_{\mathrm{Nd}}$ parameter, positive values indicate shortlived juveniles sources, while negative valuesimply rocks produced by reworking of long-lived crustal materials (Wilson, 2007; Gladkochub et al., 2009).

The fourteen samples for isotopic geochemistry Sm-Nd were crushed and sprayed with an agate mill in the laboratory of samples preparation of the IGc (USP), and they were analyzed at the CPGeo-USP, by a TRITON thermionization mass spectrometer. The Sm and Nd concentrations were obtained by isotopic dilution (Henderson and Pankhurst, 1984), based on the addition of an isotopic tracer with isotopic composition and concentration known that, mixture with amount of sample established, allow to calculate the element concentrations (Rollinson, 1993). After mixing, the samples were leaching with nitric $\left(\mathrm{HNO}_{3}\right)$ and hydrochloric $(\mathrm{HCl})$ acids, the lanthanide elements were separated using ion exchange columns with RE and Ln Resins of EIChroM Industries, and the rations were reading by TRITON mass spectrometer (TIMS). The uncertainties for the ${ }^{147} \mathrm{Sm} /{ }^{144} \mathrm{Nd}$ and ${ }^{143} \mathrm{Nd} /{ }^{144} \mathrm{Nd}$ ratios were less than $\pm 0.0014 \%(2 \sigma)$ and \pm $0.000013 \%(2 \sigma)$, respectively, based on repeated analyzes with international standards JNdi- 1 .

\subsubsection{GEOCHRONOLOGY U-Pb SHRIMP IN ZIRCON}

The chemistry characteristics of the zircon, make it resistant to magmatic, metamorphic and subsequent hydrothermal and erosional processes, in which the internal textures preserved reflect episodes of formation or consumption of zircon (Corfu, 2003). Generally, the uranium- 
bearing in the zircon is behaves as close geochemistry system, related with the different chemical behavior of $\mathrm{U}$ and $\mathrm{Pb}$, this condition yields concordant ages and establishes that the $\mathrm{Pb}$ content measured is related with the radioactive decay of $\mathrm{U}$, however, some zircon crystals generate discordant ages, due the Pb loss in the system (Misra, 2012). The U-Pb SHRIMP technique was used to determinate the crystallization age of mafic and acid samples, as well as the deposition age of metavolcanosedimentary rocks Four samples were prepared according to the procedure established in the Geochronology Research Center of the University of São Paulo (CPGeo-USP) in order to obtain the zircons from each sample. The methodology includes crushing with disk mill, sieving, hydraulic process with Wiffley table, removing of magnetic from nonmagnetic fraction using hand magnet and an electromagnetic device (FRANTZ) and density (bromoform-density=2.85 and metilene-density=3.32) separation. In the resulting fraction, the zircons were handpicking trying to catch all grains without preferential selection to certain typology. The select crystals were mounted in an epoxy disk and polished with diamond compound to show cross sections, subsequently, reflected and transmitted light images were taken. The epoxy disk was cover by gold and cathodoluminescence were acquired by FEI Quanta 250 Scanning Electron Microscope (SEM) and XMAX CL detector (Oxford Instruments) (Sato et al., 2014).

The data geochronology was measured in the Laboratory of High Resolution Geochronology of the Institute of Geoscienses of the University of São Paulo (GeoLab-IGc-USP) using the mass spectrometer model SHRIMP IIe/MC second generation with multicollector detector system with five multi-ion counting, one electron multiplier and one Faraday cup (Sato et al., 2014). The acquisition of the U-Pb data in SHRIMP II was taken through 5 analytical cycles per crystal, with $\sim 30 \mu \mathrm{m}$ diameter spot and 1 standard (Temora 2) to 4 zircon grains. The ${ }^{206} \mathrm{~Pb}^{+} / 238 \mathrm{U}^{+}$measured was adjusted with calibration line of know age (416.78 Ma for Temora 2) (Black et al., 2004), and reduced with ${ }^{207} \mathrm{~Pb}$ and ${ }^{208} \mathrm{~Pb}$ corrections using SQUID 1.06 (Sato et al., 2014). The U-Pb SHRIMP data were processed in ISOPLOT 4 program (Ludwing, 2003).

\subsubsection{U-Pb LA-ICP-MS ANALYSIS IN ZIRCON}

The U-Pb geochronology was used for stablish the maximum deposition age of a metarenite sample, this method like the U-Pb SHRIMP is based on in the transformation of $\mathrm{U}$ into $\mathrm{Pb}$ by radioactive decay in the zircon crystal lattice. Detrital zircons were obtained after crushing and sieving one metarenite sample, the fractions retained were separated using heavy liquid and magnetic techniques. The zircons selected by handpicking were mounted in $2 \mathrm{~cm}$ diameter epoxy resin and polished to generated reflected and cathodoluminescense (CL) images in order 
to know the internal complexities of the zircons and choose the better location for the analysis spot.

The U-Pb LA-ICP-MS in zircon was performed at the Institute of Geosciences of the University of São Paulo, using Thermo-Fisher Neptune Laser-ablation multi-collector inductively coupled plasma mass spectrometer (LA-ICP-MS) equipped with a $193 \mathrm{~nm}$ ArF Photon laser system. The $29 \mu \mathrm{m}$-diameter spot, work with a frequency of $6 \mathrm{~Hz}$ and intensity of $6 \mu \mathrm{J}$ and. The ablated was carried by $\operatorname{Ar}(\sim 0.7 \mathrm{~L} / \mathrm{min})$ and $\mathrm{He}(\sim 0.6 \mathrm{~L} / \mathrm{min})$ in analyses of 60 cycles of $1 \mathrm{~s}$ (more details of the technique, can find in Sato et al., 2010). The ${ }^{207} \mathrm{~Pb} /{ }^{206} \mathrm{~Pb}$ ratio was used to normalize both the NIST and external standards. The GJ standard (602 $\pm 4.4 \mathrm{Ma}$; Elhlou et al., 2006) was used following the routine of 2 blanks, 3 standards, 13 unknowns, 2 blanks and 2 standards. The residual common $\mathrm{Pb}$ and instrumental discrimination were corrected using the known terrestrial composition (Stacey and Kramer, 1975) and the reference zircon standard (GJ-1) (Jackson et al., 2004), respectively. The data are portrayed in Concordia diagram generated in the ISOPLOT 4 program (Ludwing, 2003).

\subsubsection{SPO FABRIC}

The Shape Preferential Orientation (SPO) analyses were carried out in four samples with the purpose of characterize the planar and linear fabrics from directional (preferential orientation) and scalar (magnitude and shape) parameters; the methods used were: inertia tensor and the calculation of strain ellipsoid (3D) of three planes from quadratic shape tensor.

\section{- Inertia tensor}

The technique measures the shape ratio, $r$, and long-axis orientation, $\phi$, of each individually digitized grain, with which the mean ratio, $S R_{t}$, and average orientation, $\phi_{t}$, for the grain populations is calculated (Launeau and Cruden, 1998). The process is performed in raster images of thin sections or rock faces conformed by pixels of grains $(j)$. The pixels have $(x i)$ and $(y i)$ coordinates and surface area $(A)$, equivalent to the number of pixels. The inertia tensor $\left(M_{j}\right)$ of shape is:

$$
M_{j}=\left[\begin{array}{ll}
m_{x x j} & m_{x y j} \\
m_{x x j} & m_{y y j}
\end{array}\right]
$$

With:

$$
m_{x x j}=\frac{1}{A} \sum i(x i-x c)^{2} ; \quad m_{x y j}=\frac{1}{A} \sum i(x i-x c)^{2}(y i-y c) ; m_{y y j}=\frac{1}{A} \sum i(x y-y c)^{2}
$$


Where (xc, yc) are the coordinates of the grain centroid, calculated from the average of (xi, yi) of each grain.

The shape ratio, $r$, is defined as: $r=\left(\frac{\lambda_{1}}{\lambda_{2}}\right)^{\frac{1}{2}}$, where $\lambda_{1} \wedge \lambda_{2}$ correspond with the eigenvalues of $M_{j}$, and the long-axis orientation, $\phi$, is correlate with the higher eigenvalue.

$$
\phi_{j}=\frac{1}{2} \arctan \frac{m_{x y}}{m_{x x}-m_{x y}}
$$

The size of the semi-major $(a)$ and semi-minor $(b)$ axis of grain ellipse is calculated from the expression: $a=\left(\lambda_{1}\right)^{\frac{1}{2}}$ and $b=\left(\lambda_{2}\right)^{\frac{1}{2}}$. The total preferential orientation of the grains population is determinate with the average inertia tensor $(\mathbf{M})$ of $N$ variable irregular shape grains, $\mathrm{j}=1$ to $\mathrm{N}$ (Launeau et al., 1990).

$$
M=\frac{1}{N} \sum_{j} M_{j}=\frac{1}{N}\left[\begin{array}{ll}
\sum_{j} m_{x x j} & \sum_{j} m_{x y j} \\
\sum_{j} m_{x y j} & \sum_{j} m_{y y j}
\end{array}\right]
$$

The mean ratio, $S R_{t}=\left(\frac{\lambda_{1}}{\lambda_{2}}\right)^{\frac{1}{2}}$, and the average orientation, $\phi_{t}$, are given by the eigenvalue and autovectors maximum, respectively. The semi-major $(a)$ and semi-minor $(b)$ axis total are deduced in the same way, $a=\left(\lambda_{1}\right)^{\frac{1}{2}}$ and $b=\left(\lambda_{2}\right)^{\frac{1}{2}}$.

- Strain ellipsoid (3D)

The method consists in established the best ellipsoid solution from sectional ellipses determinate in perpendicular sections or with random orientation (Robin, 2002). The technique was implement in the ELLIPSOID program (Launeau and Robin, 2003), in which each sectional ellipse and the ellipsoid solution are define as two-dimensional quadratic tensor and three-dimensional quadratic tensor, respectively, and the ellipsoid principal axes are determinate by its eigenvalues and eigenvectors.

The two-dimensional quadratic tensor is calculated from the long $(a)$ and short $(b)$ axis magnitude and the long-axis orientation $(\varphi)$, measured in relation to the $x$ direction in the $x y$ plane:

$$
\left[\begin{array}{cc}
\cos \varphi_{x y} & -\sin \varphi_{x y} \\
\sin \varphi_{x y} & \cos \varphi_{x y}
\end{array}\right] \times\left[\begin{array}{cc}
\frac{1}{a_{x y}^{2}} & 0 \\
0 & \frac{1}{b_{x y}^{2}}
\end{array}\right] \times\left[\begin{array}{cc}
\cos \varphi_{x y} & \sin \varphi_{x y} \\
-\sin \varphi_{x y} & \cos \varphi_{x y}
\end{array}\right]=S_{x y}
$$




$$
\left[\begin{array}{ll}
X X_{x y} & X Y_{x y} \\
X Y_{x y} & Y Y_{x y}
\end{array}\right]=\left[\begin{array}{ll}
S_{x x} & S_{x y} \\
S_{x y} & S_{y y}
\end{array}\right]=S_{x y}
$$

The same process is use to calculated the two-dimensional quadratic in the $y z$ and $x z$ orthogonal planes. The three-dimensional quadratic tensor is deduced from:

$S=\left[\begin{array}{lll}S_{x x} & S_{x y} & S_{x z} \\ S_{x y} & S_{y y} & S_{y z} \\ S_{x z} & S_{y z} & S_{z z}\end{array}\right]=\left[\begin{array}{ccc}\cos \alpha \cos \varphi-\sin \alpha \cos \theta \cos \varphi & -\cos \alpha \sin \varphi-\sin \alpha \cos \theta \cos \varphi & \sin \alpha \sin \theta \\ \sin \alpha \cos \varphi-\cos \alpha \cos \theta \cos \varphi & -\sin \alpha \sin \varphi+\cos \alpha \cos \theta \cos \varphi & -\cos \alpha \sin \theta \\ \sin \theta \sin \varphi & \sin \theta \cos \varphi & \cos \theta\end{array}\right]$

In the shape matrix of ellipsoid $(S)$, the values of $\alpha, \theta \wedge \varphi$ correspond with the azimuth, direction and dip of ellipsoid, and the $\mathrm{A} \geq \mathrm{B} \geq \mathrm{C}$ axes are determinate by the eigenvalues and eigenvectors of $S$.

\subsubsection{QUARTZ C-AXIS FABRIC}

The Lattice Preferred Orientation (LPO) is related with the orientation of the crystallographic axes of the constituent minerals (Passchier and Trouw, 2005). In the universal stage optical microscopy accesory (U-Stage), the thin section is mounted between two glass hemispheres and is surrounded by external axes (N-S axis, inner ring axis, E-W axis). According with the methodology described by Santoro (1998), the thin section is rotated in a particular orientation with respect the external axes, until the orientation and inclination of c-axes are obtained. In seven samples (cut along XZ planes), recrystallized quartz c-axes were measured through universal stage of four-axis. The data taken (horizontalized or verticalized) were converted into standard annotations with north or south reference azimuth and subsequently projected by isofrequence curves in Stereo32 program version 1.0.3 (Röller and Trepmann, 2011), with the purpose of analyze the quartz c- axis patterns and measure the opening-angle. 


\title{
CHAPTER 2
}

\section{Geological map of Itaiacoca Group and Bairro dos Prestes Formation, between Itapeva and Ribeirão Branco region (SE Brazil $)^{1}$}

\begin{abstract}
We present a new 1:25,000-scale geological map from the region between Itapeva and Ribeirão Branco belonging to the Neoproterozoic Ribeira Belt in Southeast Brazil near the border of the Paleozoic Paraná sedimentary basin. The mapping was carried out through field geological methodologies, with the help of aerial photographs, digital elevation model and aerogeophysical survey data, as will the reinterpretation of former geological cartography. The cartographic products were prepared with GIS and assisted drawing software. Eleven lithostratigraphic units were identified: Quaternary alluvial deposits, Jurassic-Cretaceous basic dykes (associated with the Paraná-Etendeka volcanism), the Carboniferous-Permian Itararé Group (from the Paraná Sedimentary basin), a Late Ediacaran metasedimentary unity located on the eastern flank of the Apiaí-Guaçu river, the Neoproterozoic Ribeirão Grande Granite, three formations (Serra dos Macacos, Água Nova, Bairro dos Campos) and one magmatic suite (Fazenda Velha Metabasic Suite Formation) from the Neoproterozoic Itaiacoca Group, the Statherian Bairro dos Prestes Formation and Apiaí Mirim Complex. The Proterozoic units were affected by three folding phases and NE-SE and NNE-SSW to NNW-SSE strike-slip faults. This detailed cartography work, allowed to perform petrography, geochronology and geochemistry characterization of the lithostratigraphic units, useful information for the interpretation of the geotectonic context of the Ribeira belt, as well can be used for applied works.
\end{abstract}

Key-words: Geological map; Itaiacoca Group; Bairro dos Prestes Formation; Ribeira Belt; Itapeva, Ribeirão Branco

${ }^{1}$ Forero-Ortega, A.J., Campanha, G.A.C., Faleiros F.M. 


\subsection{INTRODUCTION}

The mapping area is located in the south of Ribeira belt (Almeida et al., 1973; Hasui et al., 1975) (Figure 2.1), a Neoproterozoic Pan African - Brasiliano orogen in the Southeast Brazil, affected by the extensional events of the Rodinia supercontinent and fusion of the Godwana Supercontinent (Brito Neves et al., 1999; Brito Neves, 2002; Cordani et al., 2003; Basei et al., 2005; Silva et al., 2008). It belongs to the so called Apiaí terrane of the Ribeira belt (Campanha and Sadowski, 1999; Campos Neto, 2000).

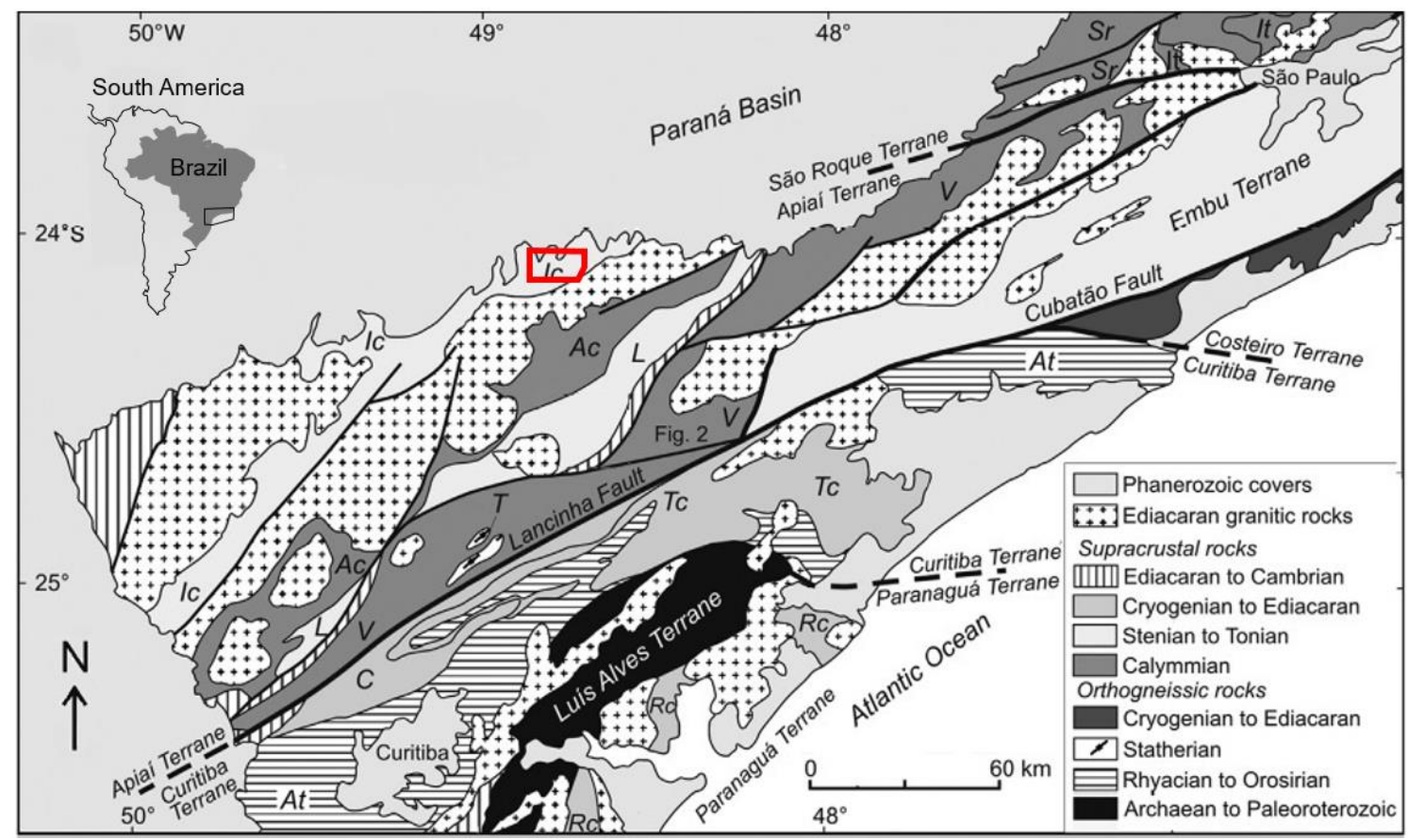

Figure 2. 1. Simplified geotectonic map of the Southwestern portion of the Ribeira Belt with location of study area Figure 2.2. (From Campanha et al., 2015)

The area is situated in the border of the Paleozoic Paraná sedimentary basin, locally represented by the Itarare Group. It covers unconformably Proterozoic units comprising the Ediacaran Itaiacoca Group (Almeida, 1956; Forero-Ortega et al., 2018), the Statherian Bairro dos Prestes Formation (Forero-Ortega et al., 2018), and the Apiaí-Mirim Complex (Prazeres Filho, 2005; Siga Jr, 2010), as well an Ediacaran intrusive granite pluton (Ribeirão Branco granite), the Apiaí-Guaçu metasandstone, Mesozoic intrusive diabase dikes and Quaternary alluvial deposits.

The Itaiacoca Group was defined originally by Almeida (1956) and has been studied by several authors as Petri and Suguio (1969), Chiodi Filho et al. (1983, 1984), Bistrichi et al. (1985), Trein et al. (1985), Soares (1987a, 1987b), Santoro and Frascá (1989), Souza (1990, 1992), 
Gimenez Filho, (1993), Reis Neto (1994), Fassbinder (1996), Prazeres Filho et al. (1998), Sallun Filho (1999), Sallun Filho and Fairchild (2004, 2005) and Siga Jr. et al (2003, 2009). The Itaiacoca Group constitutes a narrow and long belt of folded and deformed metasedimentary rocks bounded to the east by the Itapirapuã Fault. Its structural framework is characterized for the most authors by three deformational events, the first created isoclinal and asymmetric folds, developing sub-parallel cleavage to the contacts and pelitic intercalations, the second generated isoclinal folds, with slaty and crenulation cleavage as axial planes, and the third event is responsible for the open regional folds and the steep dip of the mean foliation caused by the transcurrent fault (Takahashi et al., 1984; Soares, 1987a; Theodorovicz et al., 1988; Lima, 1993b).

Following the latest publications (e.g., Caltabellotta et al., 2016) we adopt here with modifications the stratigraphic scheme of Souza $(1990,1992)$ for the Neoproterozoic Itaiacoca Group, divided it in three formations: Serra dos Macacos, Bairro dos Campos and Água Nova. The Bairro da Estiva Formation (Souza, op.cit.) is not outcropping in the studied area. We defined the Fazenda Velha Metabasic Suite, separated from the Água Nova Formation, due its extension and mappable character. The Bairro dos Prestes Formation, following an informal name of Theodorovicz et al., (1988), and due to recent geochronological data (Forero et al., 2018), is defined here as a Mesoproterozoic metasedimentary-metavolcanic unit, detached from the Itaiacoca Group.

Former semi-detailed geologic maps (1:50.000) encompassing the studied area were presented by Takahashi et al. (1984), Theodorovicz et al. $(1986,1988)$ and Vieira (2017).

The objective of this paper is to present a detail cartography and description of the stratigraphy and structural geology of the area in order to contribute to the understanding of the geotectonic setting of these units and can be used for applied works.

\subsection{METHODS AND SOFTWARE}

We mapped an area of $128 \mathrm{Km}^{2}$ at 1:25,000-scale, in the region between Itapeva and Ribeirão Branco, recording 134 outcrop sites with geological and structural information as well samples were collected for petrographic, microstructural, geochronological and geochemical analyzes. The field tracks were done preferably orthogonally to the regional structural trend but due the scarcity of outcrops in some areas all roads and paths were covered. The geological mapping and interpretation were assisted with 1:25,000 and 1:60.000 scale aerial photographs, former 1:50.000 scale cartographic and geological maps, digital elevation model (STRM 1 Arc-second 
global) and aerogeophysical (gamma and magnetometric) maps (CPRM, 2011). The former cartographic information was carried in the field with the mobile map app Avenza Maps® and outcrop positions and tracks recorded with a GPS Garmin.

The Map digitalization was performed with the Esri ArcGIS 10.4 software, using an elevation model (STRM 1 Arc-second global, U.S. Geological Survey), as background and the hillshade tool for to highlight the structures. Maps, outcrop points and images were georeferenced to the Universal Transverse Mercator (UTM) coordinate system (WGS 84 Horizontal Datum, 22S zone). The geological profiles were draw with the Corel Draw Graphics Suite X5, from the scaled vertical profiles generated in ArcGIS.

The Geological map and cross-sections are available in the appendix 2 and 3.

\subsection{RESULTS}

\subsubsection{Lithostratigraphic units}

In the study area eleven lithostratigraphic units were identified, according to their lithological, metamorphic, structural and chronological characteristics. They are: (1) Quaternary alluvial deposits, (2) Jurassic-Cretaceous basic dykes (associated with the Paraná-Etendeka volcanism), (3) the Carboniferous-Permian Itararé Group (from the Paraná Sedimentary basin), (4) a Late Ediacaran metasedimentary unity located on the eastern flank of the Apiaí-Guaçu river, (5) the Neoproterozoic Ribeirão Grande Granite, (6) three formations (Serra dos Macacos, Água Nova, Bairro dos Campos) and one magmatic suite (Fazenda Velha Metabasic Suite) from the Neoproterozoic Itaiacoca Group, (7) the Statherian Bairro dos Prestes Formation and (8) Apiaí Mirim Complex.

\subsubsection{Quaternary Alluvial Deposits}

The Quaternary alluvial deposits in the study area occur along the banks of the main rivers, forming terraces along the floodplains. They consist of unconsolidated sand banks, with variable granulometry, sometimes developing cross bedding.

\subsubsection{Jurassic-Cretaceous Diabase Dykes}

The Jurassic-Cretaceous basic dykes are related with the Paraná-Etendeka volcanism associated with the rifting and opening of Atlantic Ocean in the Mesozoic. They are present in the study 
area as NW-SE dykes. They are comprised of medium to coarse-grained basic rocks, with subophitic textures, and composed of hornblende, plagioclase, quartz, potassic feldspar, biotite and aggregates of sericite and saussurite (Figure 2.2)

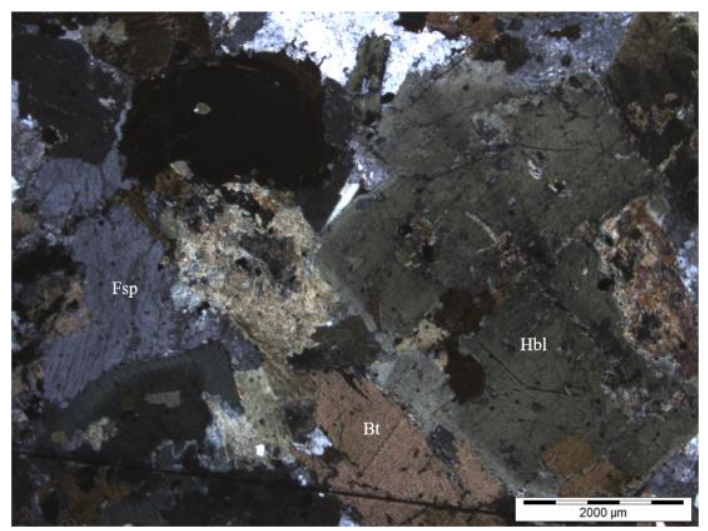

Figure 2. 2. Thin-section of Jurassic-Cretaceous basic rock in cross-polarised light.

2.3.1.3 Itararé Group: poorly selected fine-grained to conglomeratic sandstone and argillite.

The Itararé Group maintain a flat but higher topography expression in the central-west part of the study area, resting in erosive discordance over the Proterozoic units. It is composed by argillites, yellow to reddish feldspathic and micaceous sandstones, varying from fine to very coarse grain (conglomeratic sandstone). The sedimentary rocks present primary structures as parallel and cross bedding (Figure 2.3a), ripple marks (Figure 2.3c), as well syn-sedimentary deformation structures (Figure 2.3b).

a.
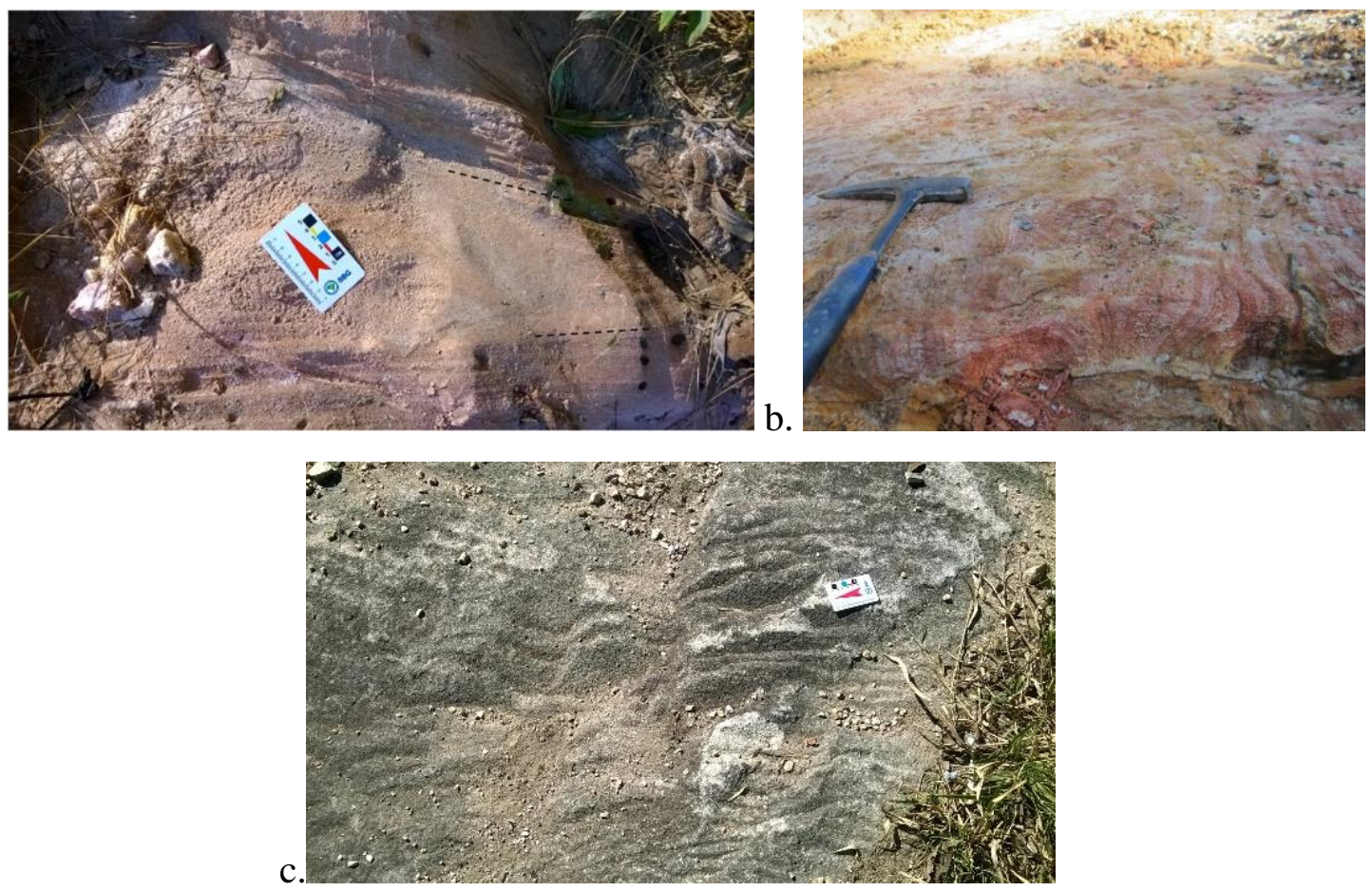
Figure 2. 3. Outcrops of sedimentary rocks of Paraná basin (Itararé Group), in which is possible to identify: (a) cross bedding of fine sandstone, (b) syn-sedimentary fold of the layers of reddish sandstone and (c) ripple marks developed in coarse sandstone.

\subsubsection{Apiaí-Guaçu Metasandstone}

This metasedimentary unit is present on the eastern flank of the Apiaí-Guaçu river. It is comprised of fine to coarse-grained feldspathic quartz metasandstones intercalated with small beds of mudstone. In the unit outcrops are also possible to recognize primary structures (bedding planes, Figure 2.4) and cleavage plane obliquely to them.

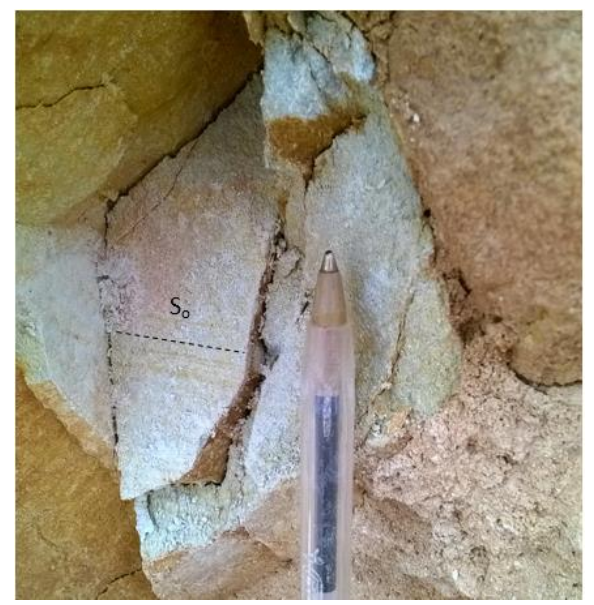

Figure 2. 4. Apiaí-Guaçu metasandstone with primary structures (bedding), recognizable by the color alternation of the laminations.

2.3.1.5 Ribeirão Branco Granite: porphyritic monzogranite and subordinate sienogranite.

Ribeirão Branco Granite is part of Três Córregos Granitic Suite (Caltabellotta, 2016). In the study area, it outcrops as sparse boulders and blocks, irregularly distributed. Microscopically, the granite has granoblastic and holocrystalline texture, consisting mainly of anhedral to subhedral crystals of quartz (Figure 2.5a-b), microcline, plagioclase, biotite, epidote, zircon (as accessory mineral) and aggregates of saussurite.

a.

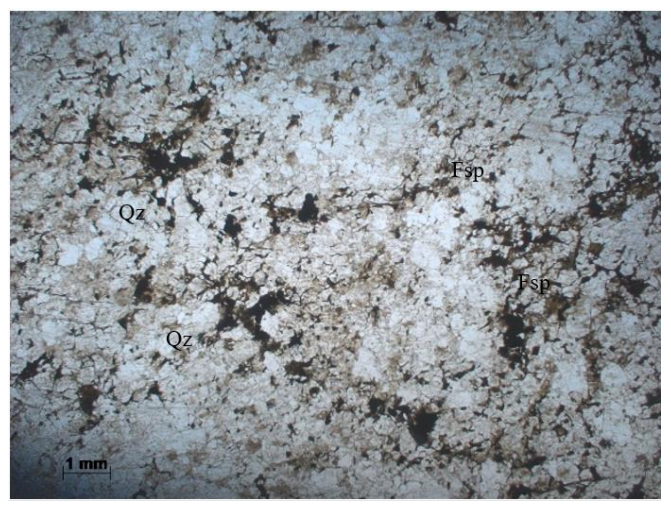

b.

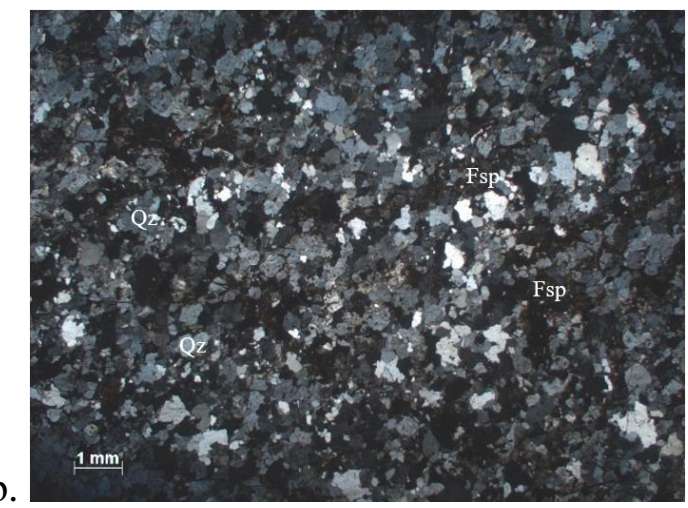


Figure 2. 5. Thin section of Três Córregos granite sample: (a) Plane-polarised and (b) cross-polarised light.

\subsubsection{Itaiacoca Group}

\subsection{Serra dos Macacos Formation: massive quartzites}

Included in the pelitic-chemical sequence of Theodorovicz et al. (1986), this unit has a strong topography expression in the northwest portion of the study area, around the Alta da Brancal village. The outcrops are comprised of massifs quartzites (Figure 2.6), heavily fractured. Based on observation in thin sections, Theodorovicz et al. (1986) describe that the massifs quartzites (metachert, in their work) are composed by fine quartz mass, with development of quartz venules, and small agglomerates of sericite distributed locally. The massif quartzite is in normal contact, overlapping the Bairro dos Campo metalimestone unit.

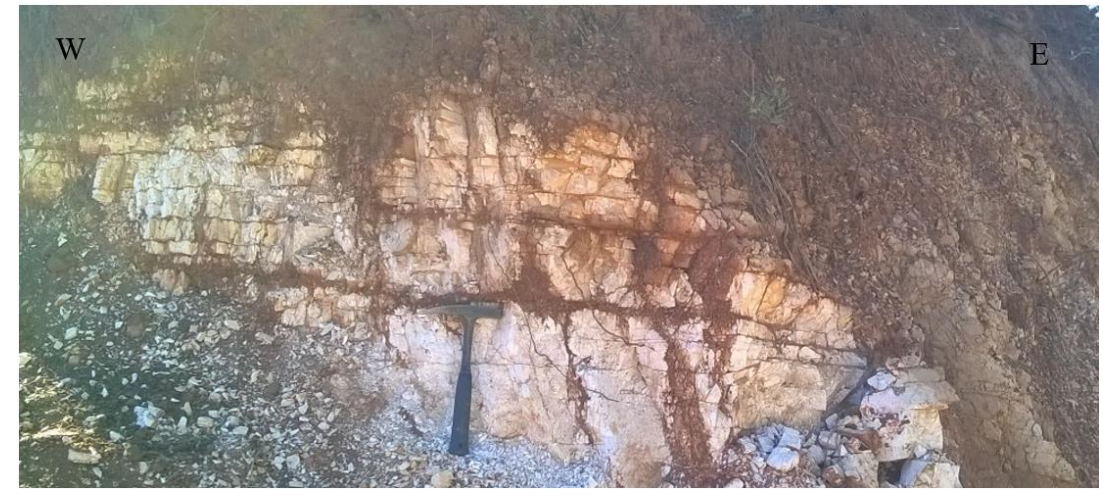

Figure 2. 6. Outcrop of quartzite from the Serra dos Macacos Formation

2.3.1.6.2 Fazenda Velha Metabasic Suite: mainly metabasic rocks, with intercalations of metadolomites, talc schists and chlorite schists.

This unit is comprised of significant amounts of metabasites, with intercalations of metadolomite, talc and chlorite schist and occasionally metarcoses. In the transitional contact with metapelites of Água Nova Formation presents steep dips and increment of the foliation intensity. The representative lithotypes of metamafic rocks are metabasalts and metagabbro with massive structure and green to dark green colors. 
a.

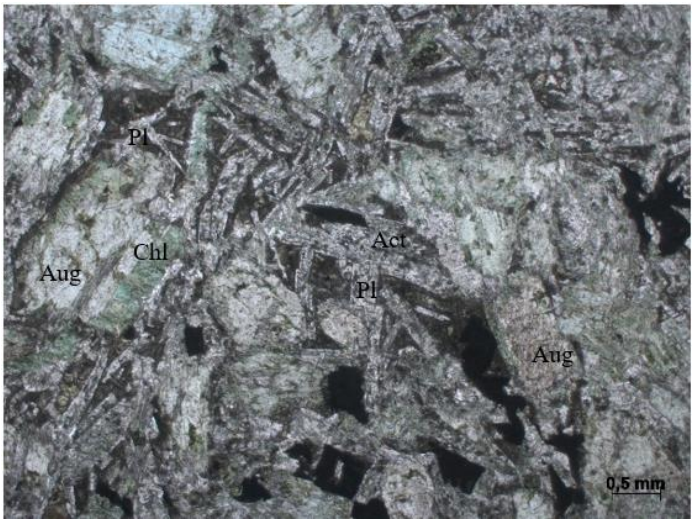

c.

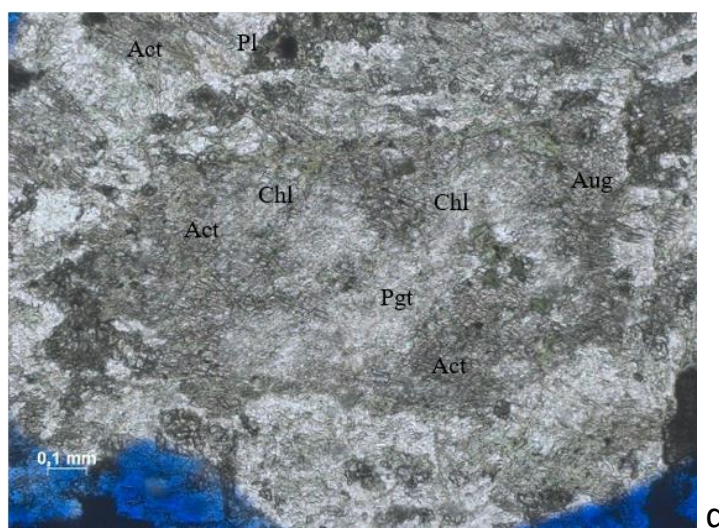

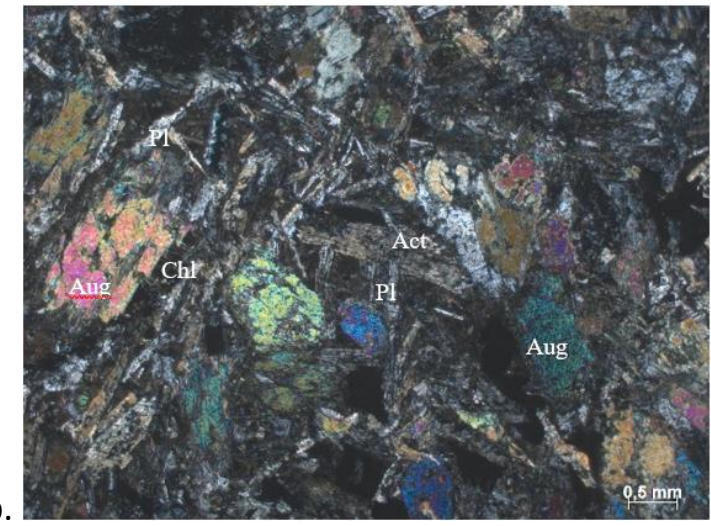

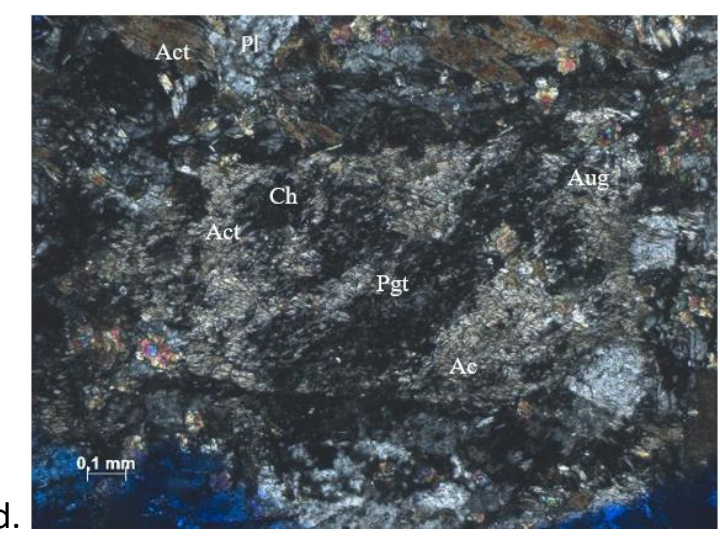

Figure 2. 7. Thin section of metabasic rock from Fazenda Velha Metabasic Suite in which are possible to observe: reliquiar subophitic texture under plane-polarised (a) and cross-polarised light (b), pseudomorphs of with chemical zoning under plane-polarised (c) and cross-polarised light (d).

Microscopically, the metabasites consist of augite, plagioclase, epidote, clinozoisite, quartz, saussurite aggregates, oxides (titanomagnetite, rutile and ilmenite) and opaque minerals. Pseudomorphs of chemically zoned pyroxene show core domains with higher content of $\mathrm{Mg}$ (pigeonite composition) that allows the formation of chlorite, and on the edges the higher $\mathrm{Fe}$ contents facilities the actinolite aggregates nucleating (Figure 2.7c-d). Generally, the plagioclase is affected by saussuritization process. These rocks also preserved reliquiar igneous textures (subophitic and ophitic textures) (Figure 2.7a-b). The metadolomites are formed by tiny grains of dolomite and talc, while the talc schists are developed mainly in the shear planes of the massive metabasites rock, formed from deformational and hydrotermal events, which facilitated the fluid circulation and mineral alteration.

\subsubsection{3 Água Nova Formation: metamudstone and phyllites intercalated with fine-grained quartzites}

The Água Nova Formation outcrops in the northwest sector of the map. It mainly consists of generally deeply weathered intercalations of white metamudstone and yellow phyllites, 
sometimes displaying a parallel banding reflecting a compositional variation, as a relic bedding. Microscopically, the phyllites are comprised of anedric elongate quartz parallel to the main foliation, sericite, kaolinite and opaque minerals. Slaty cleavage and microfolds are common structures. This package presents a transitional contact with the metalimestones and metabasic sequences of Bairros dos Campos Formation and Fazenda Velha Metabasic Suite Formation, and it is unconformatly overlain by the sedimentary rocks of the Itararé Group (Figure 2.8).

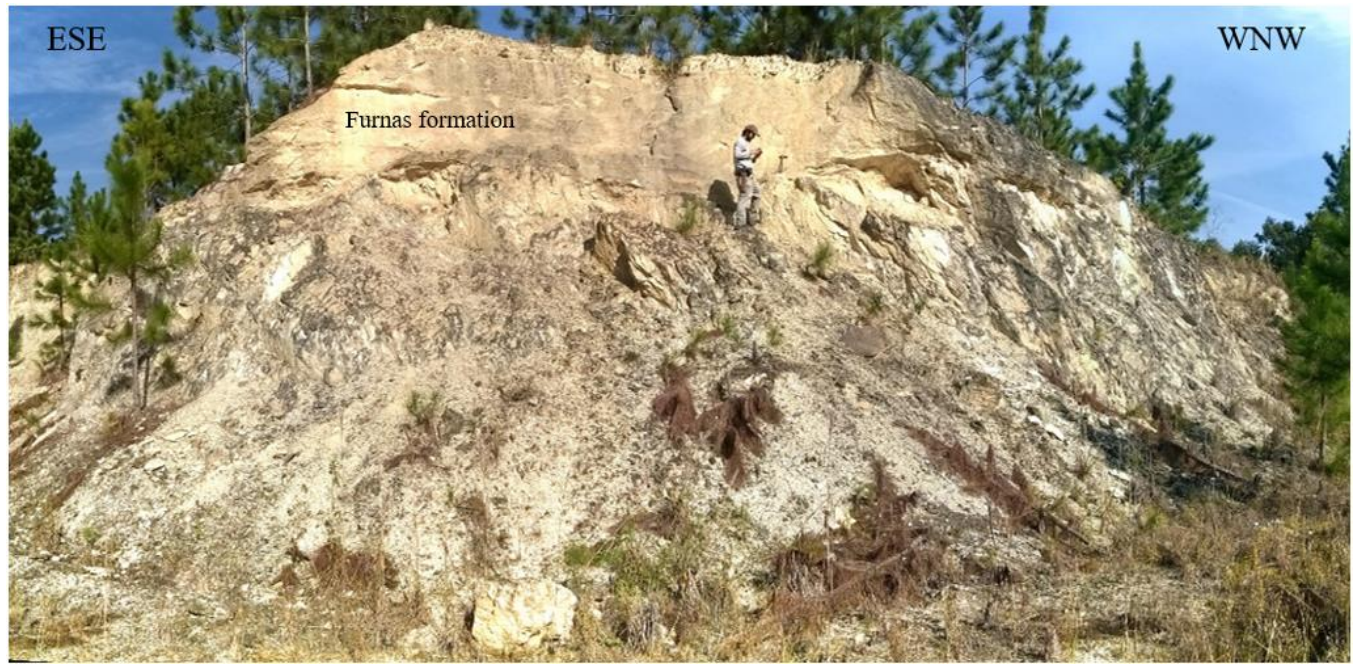

Figure 2. 8. Outcrop of Água Nova Formation, phyllites overlained in a discordant contact by the flat sedimentary rocks of the Itararé Group.

\subsection{Bairro dos Campos Formation: calcitic and dolomitic metalimestones intercalated} with phyllites and small beds of metatuff

It is part of the pelitic-chemical unit of Theodorovicz et al. (1986), comprised of dark-gray calcitic and dolomitic metalimestones, in transition contact with phyllites and with small beds of white tuff. The calcitic metalimestones are quite clayey, interbanded, and sometimes folded, with layers of massive light gray dolomitic metalimestones and marls to the northeast. It is common to find stromatoliths (conophyton) and other nonconical branched forms (Marini and Bigarella, 1967; Sallun Filho 1999; Sallun Filho et al., 2005).

Petrographically, the dolomitic metalimestones are composed of dolomite, quartz and occasionally talc, mica, chlorite and rutile, and the calcitic metalimestones are comprised of calcite, dolomite, quartz, mica, chlorite and talc (Frascá, 1992). A tuff sample presents flow texture with quartz, anhedral feldspar fragments, titanite (Figure 2.9). 


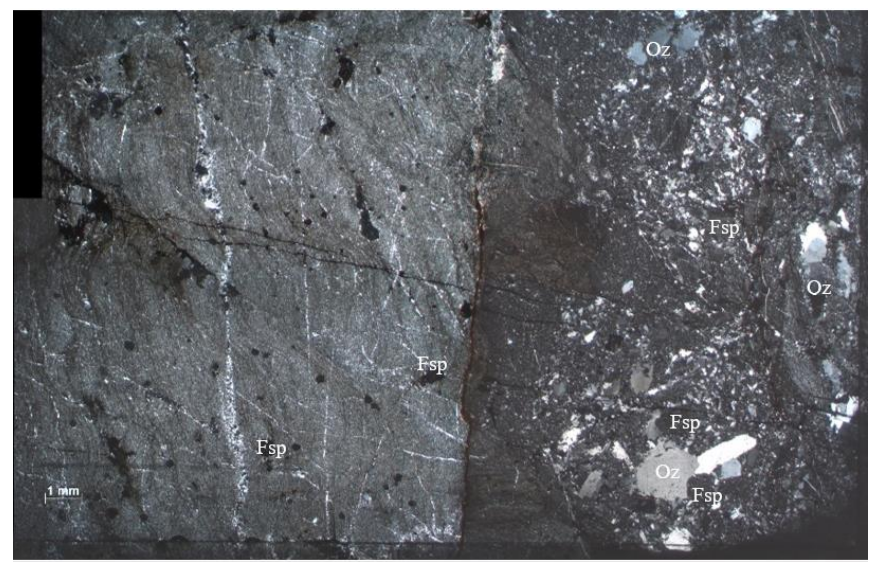

Figure 2. 9. Cross polarized light optical photomicrographs of tuff intercalation, Bairro dos Campos Formation

2.3.1.7 Bairro dos Prestes Formation: phyllite sometimes with amygdaloidal structure and intercalations of fine-grained quartzite and restricted occurrences of metarhyodacite and metaconglomerate.

The Bairro dos Prestes Formation is located at the east sector of the study area, characterized by a smooth and homogeneous topography. Here, we are giving the status of Formation to the informal name of Theodorovicz et al. (1988). It is composed by gray to green phyllites varying to red color according with the weathering degree, with interdigitated to transitional contacts with fine to medium grained quartzites and restricted occurrences of metarhyodacite and metaconglomerate. A fine foliation (slaty cleavage) is pervasive and crenulation cleavages are frequent, mainly in the phyllites.

a.
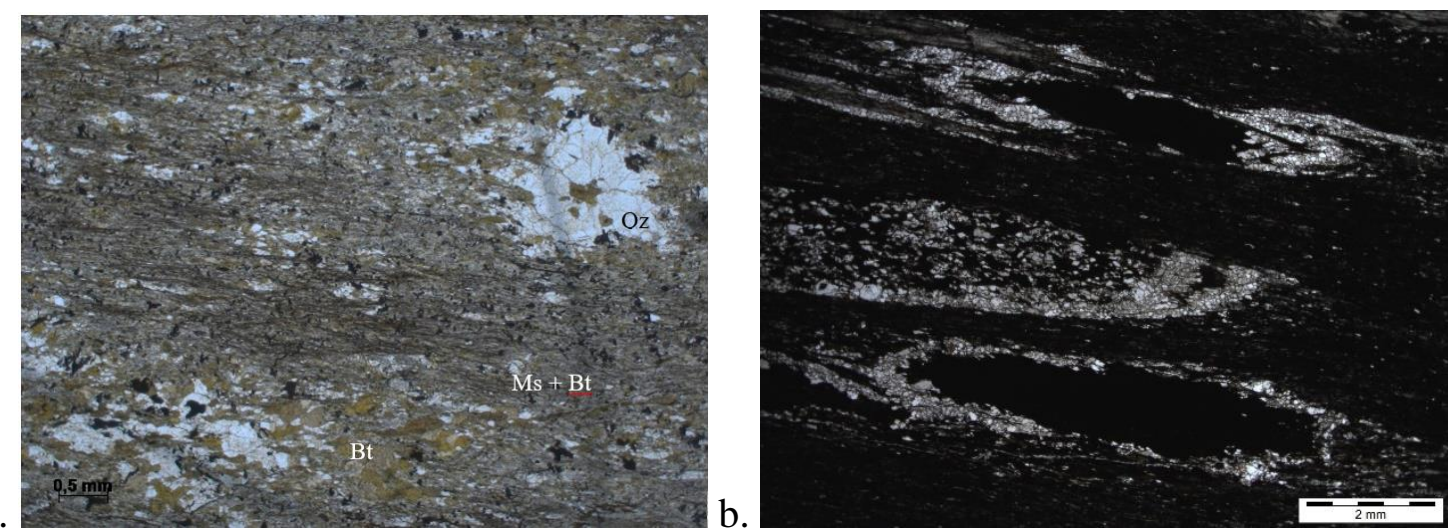

Figure 2. 10. Photomicrographies in plane-polarised light of (a) quartz-biotite phyllite and (b) quartzfeldspar-biotite phyllite, Bairro dos Prestes Formation.

Petrographically, the phyllites are comprised of fine to very fine crystals of quartz, feldspar, biotite, muscovite and tourmaline, with rutile, zircon, apatite as accessories minerals support 
by fine matrix of biotite and sericite, with lepidogranoblastic and amygdaloid textures. These textures allow to interpret at least part of the phyllites as volcanosedimentary rocks. The vacuoles are stretched parallel to the cleavage plane, being comprised of quartz, muscovite, biotite (Figure 2.10a) and oxides (Figure 2.10b).

The quartzites have expressive outcrops (Figure 2.11) with high topographical expression along their distribution, forming open folds with NE-SW axial surface and are affected by NE-SW and NNW-SSE strike-slip faults. The quartzites present a varied granulometry, from conglomeratic to fine-grained, generally silicified with well-defined schistosity planes, in which chlorite schists are interdigitated due to the interaction with hydrothermal fluids.

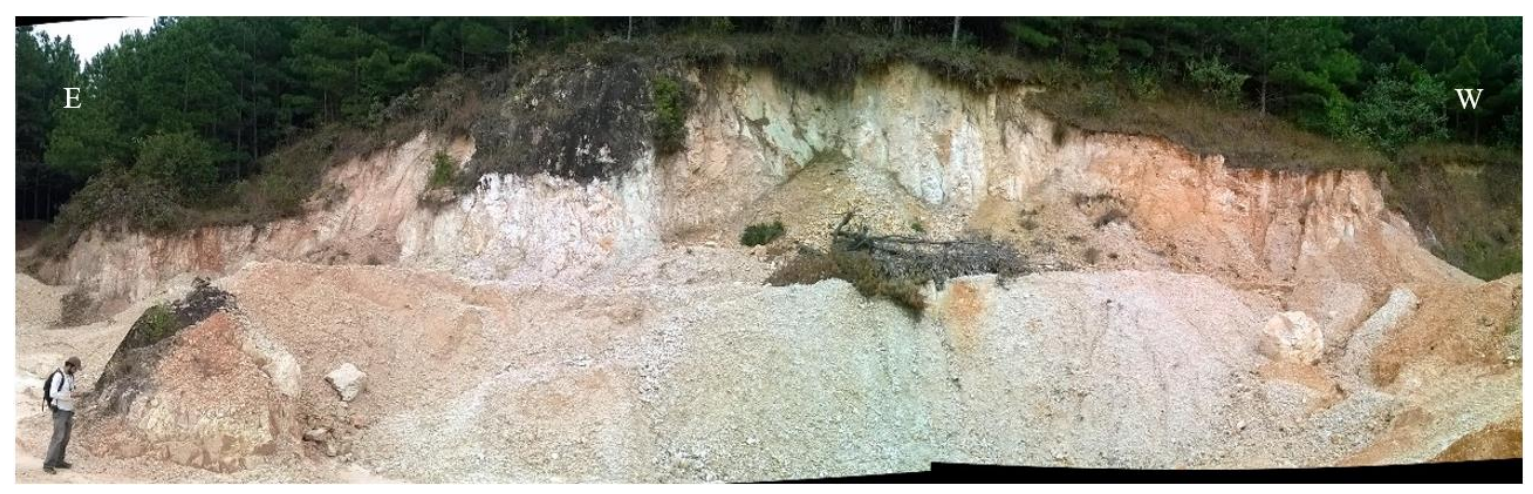

Figure 2. 11. Abandoned quartzite quarry, Bairro dos Prestes Formation.

\subsection{Metarhyodacite}

The metarhyodacite is present in the south center of the study area, as restricted rock bodies, showing a gradational contact with the adjacent phyllites. It presents resorption textures and is comprised of anhedral phenocrysts of quartz, potassic feldspar, plagioclase, biotite and muscovite set in a fine-grained matrix of quartz, biotite, white mica, K-feldspar and plagioclase. Zircon, ilmenite and rutile are the main accessory minerals (Figure 2.12a-b).

a.

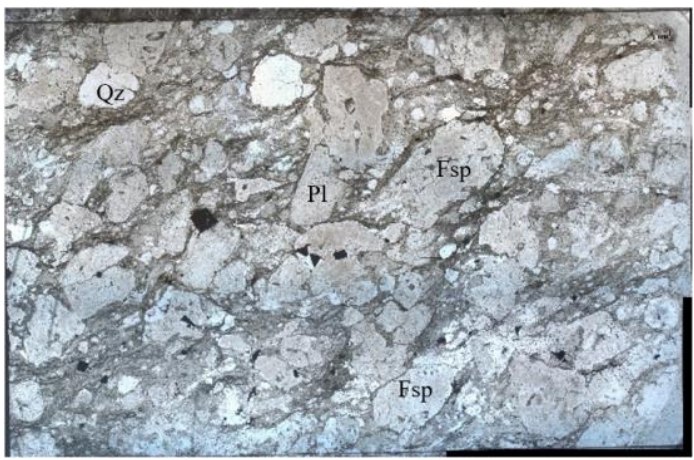

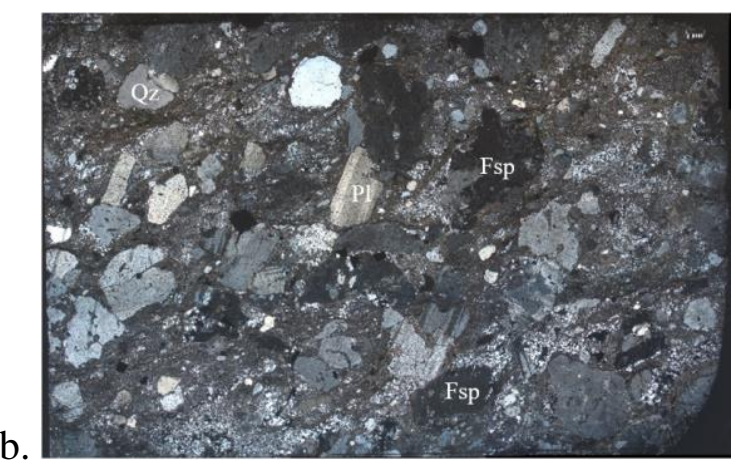

Figure 2. 12. Thin section of a metarhyodacite sample, Bairro dos Prestes Formation: (a) Planepolarised and (b) cross-polarised light. 


\subsection{Metaconglomerate}

The metaconglomerate presents interdigitated to erosive contact with the quartzites and phyllites. It is composed of volcanic (Fg. 13b), quartzite and black phyllite (Figure 2.12b) pebbles supported by a metamudstone matrix. The volcanic pebbles show deformed amygdales filled by quartz, feldspar, muscovite and biotite, supported by fine-grained matrix of sericite, biotite and opaque minerals, classified as quartz-feldspar-biotite phyllite. Some black phyllite pebbles display an internal foliation discordant from the external foliation of the metaconglomerate matrix, suggesting an erosion of a phyllite source unit.

a.
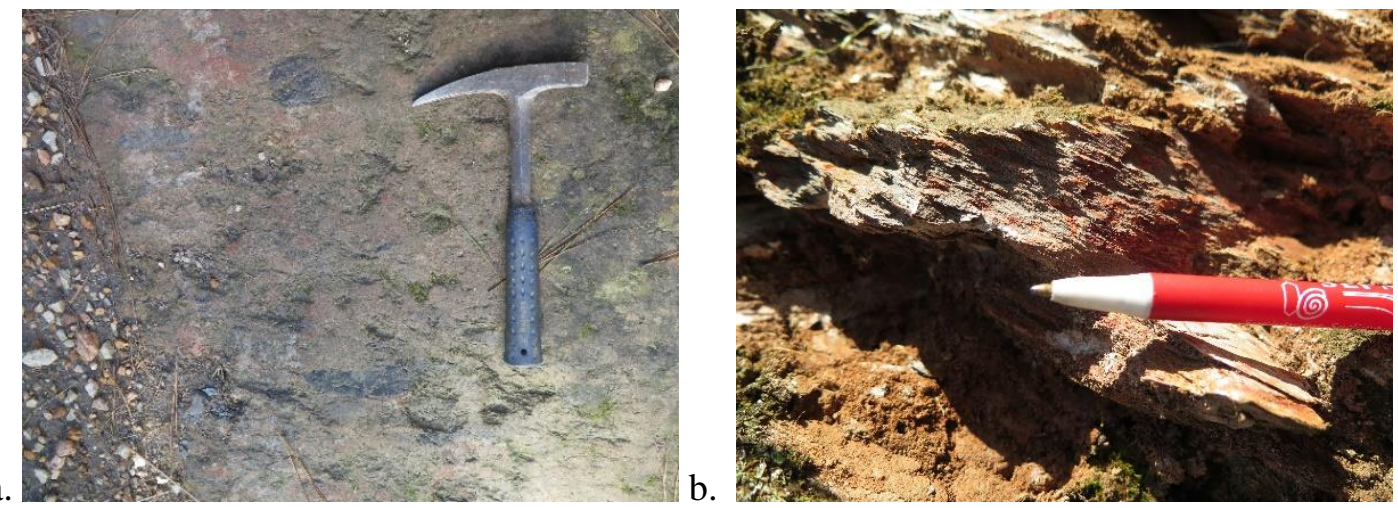

Figure 2. 13. Outcrop of metaconglomerate from Bairro dos Prestes Formation showing (a) parallel to chaotic orientation of the black phyllites clasts and (b) metavolcanosedimentary pebbles.

\subsection{Apiaí Mirim Complex: paragneiss and micaceous quartzite}

The Apiaí-Mirim Complex occurs to the southeast of the study area. The predominant lithotypes are paragneiss and medium to coarse grained micaceous quartzite. Microscopically, the paragneiss has intercalations between the granoblastic and lepidoblastic textures (Figure 2.14ab), it is composed of quartz, potassic feldspar, microcline, plagioclase, biotite, sillimanite (fibrolite), muscovite, zircon and apatite as accessories minerals. The quartzites are comprised of quartz, feldspar and micas.

a.

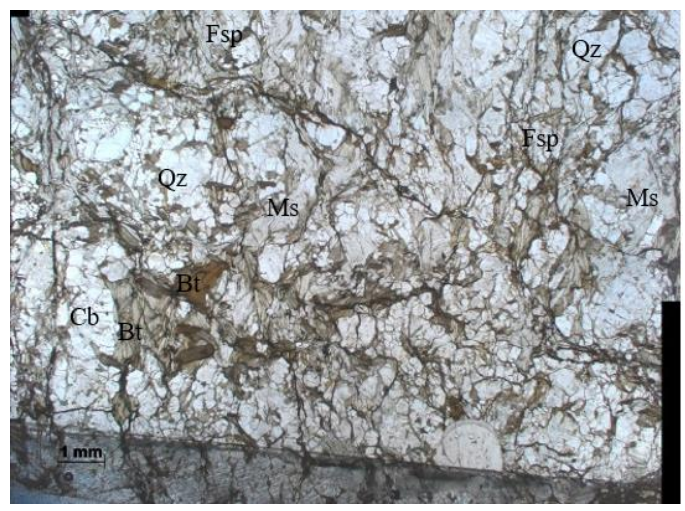

b.

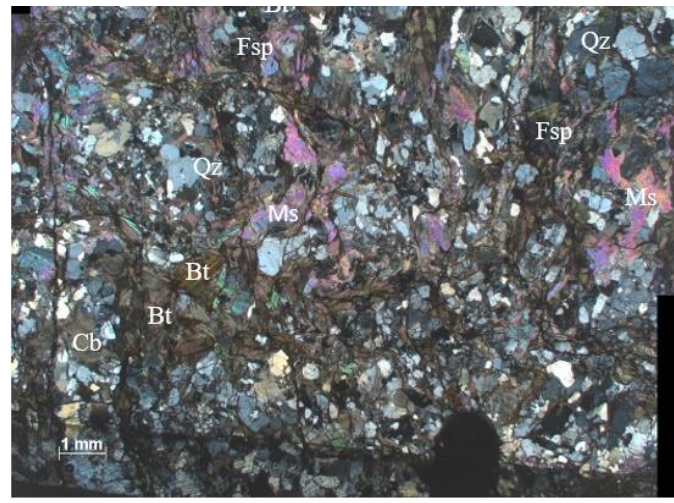


Figure 2. 14. Thin section of paragneiss sample, Apiaí-Mirim Complex: (a) Plane-polarised and (b) cross-polarised light.

\subsubsection{Structural geology}

The study area is mainly affected by NE axial-plane folds and strike-slip faults. In the east, also NNW-SSE and NNE-SSW faults are present. This structural arrangement implies in a complexity in the distribution, orientation and continuity of the rocky bodies. At the mesoscopic and microscopic level, relict structures $\left(\mathrm{S}_{\mathrm{o}}\right)$ and three foliation planes $\left(\mathrm{S}_{\mathrm{n}}, \mathrm{Sn}_{+1}\right.$ and $\left.\mathrm{Sn}_{+2}\right)$ were identified, as well stretching lineation, fold axes, small faults and folds. However, not all these structures are penetrative over the study area, especially in the metadolomite and metabasic rocks of the Itaiacoca Group, the deformational fabric is less intense due their rheological characteristics. While the deformation is more intense in the pelitic rocks and in the higher metamorphic grade rock of Apiaí-Mirim Complex.

\subsubsection{Meso and micro structural analysis}

The primary structures present in the Itaiacoca Group and Bairro dos Prestes Formation are the compositional banding in the metadolomites and metamudstone (Figure 2.15a) and laminations in phyllites rocks, which are interpreted as relic bedding (So).

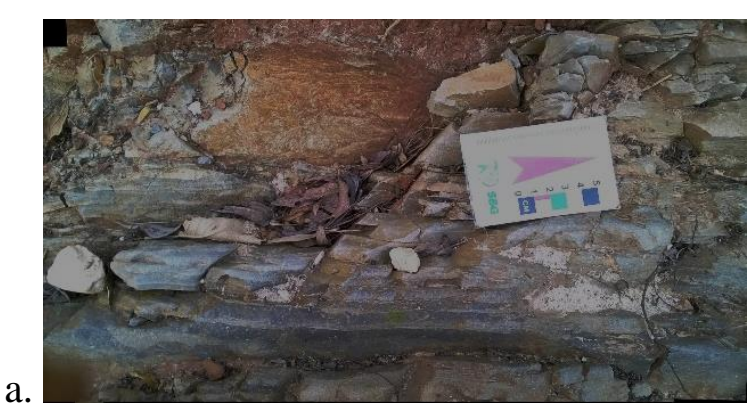

Figure 2. 15. Some of the sedimentary structures in Itaiacoca Group: (a) bedding in the metamudstone rock.

A main foliation $S_{n}$ is developed often parallel to the compositional bands (granulometric and textural variations) and laminations, assigned to the deformational event $D_{n}$. In the lower metamorphic grade rocks of the Itaiacoca Group is characterized as a fine slaty cleavage, while in the Bairro dos Prestes Formation and in Apiaí-Mirim Complex are a schistosity recognized by the size increase of micaceous minerals. 


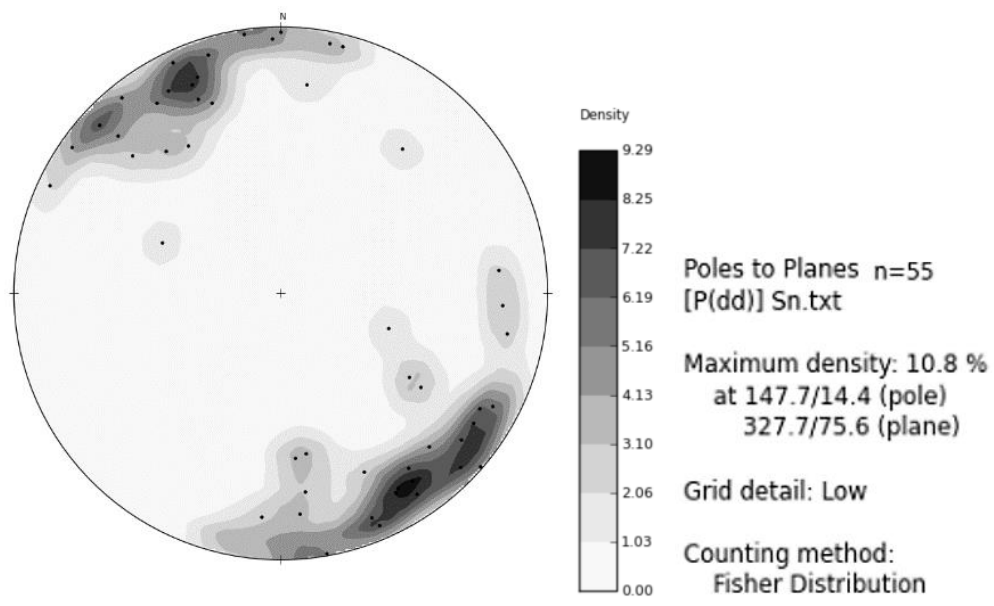

Figure 2. 16. Stereographic projection of the poles concentration of Sn (Schmidt-Lambert projection lower hemisphere, mean plane in dip direction / dip).

The principal foliation plane $\left(S_{n}\right)$ has mainly steep dips and preferential NE-SW strikes (mean attitude $\mathrm{N} 58^{\circ} \mathrm{E} / 76^{\circ} \mathrm{NW}$, Figure 2.16) defining the regional structural trend. It is also defined by the amygdales stretching in the metavolcanosedimentary rocks (Figure 2.19a), and by the preferred orientation of granoblastic crystals in quartzite (Figure 2.19b), metarhyodacite, and paragneiss rocks.

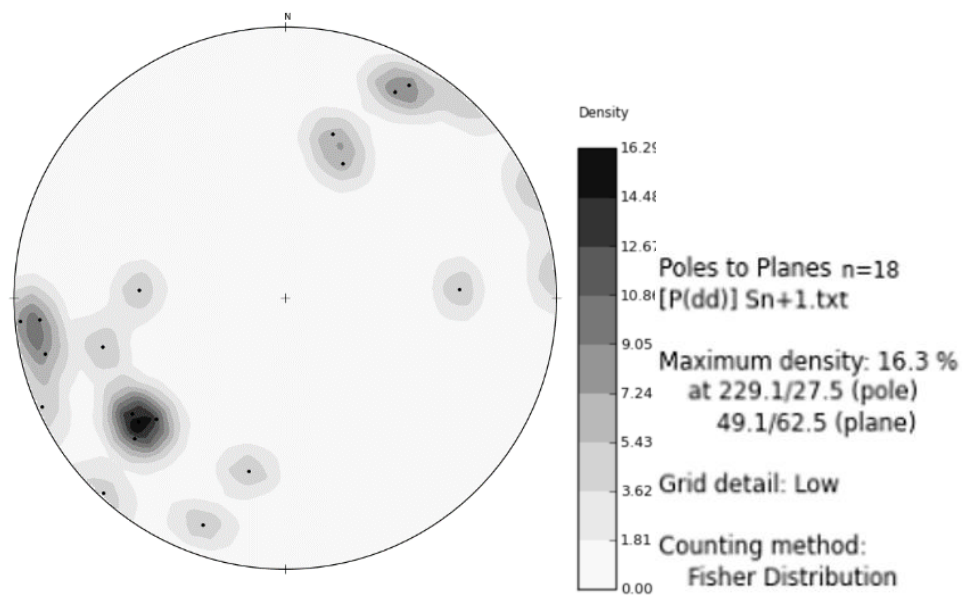

Figure 2. 17. Stereographic projection of the poles concentration of $\mathrm{Sn}+1$ (Schmidt-Lambert projection lower hemisphere, mean plane in dip direction / dip).

The $S_{n+1}$ generated in the deformational event $D_{n+1}$, affects the $S_{n}$ planes and created crenulation cleavages in metavolcanosedimentary and metapelitic rocks. It is associated with tight asymmetric folds $\left(\mathrm{F}_{\mathrm{n}+1}\right)$ with inclined to subvertical $\left(50-80^{\circ}\right) \mathrm{NW}$ axial-plane, development in the quartzite (Figure 2.19b-c), metavolcanosedimentary and metapelitic (Figure 2.19e) rocks. The $\mathrm{S}_{\mathrm{n}+1}$ are predominantly concentrate in the direction $\mathrm{N} 41^{\circ} \mathrm{W} / 63 \mathrm{NE}^{\circ}$ (Figure 2.17). 


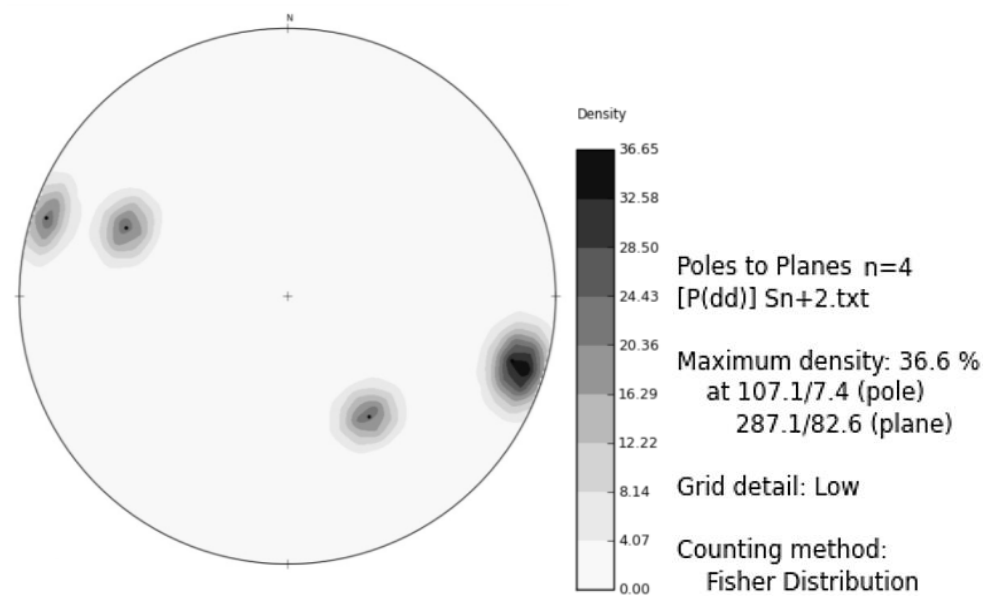

Figure 2. 18. Stereographic projection of the poles concentration of $\mathrm{Sn}+2$ (Schmidt-Lambert projection lower hemisphere, mean plane in dip direction / dip).

The $S_{n+2}$ develops in the deformational event $D_{n+2}$, produces open overfolds $\left(F_{n+2}\right)$ with inclined NE axial-plane in quartzite and phyllite rocks (Figure $2.19 \mathrm{~d}, \mathrm{~g}$ ). The $\mathrm{S}_{\mathrm{n}+2}$ are predominantly concentrate in the direction $\mathrm{N} 17^{\circ} \mathrm{E} / 83 \mathrm{SE}^{\circ}$ (Figure 2.18).

a.

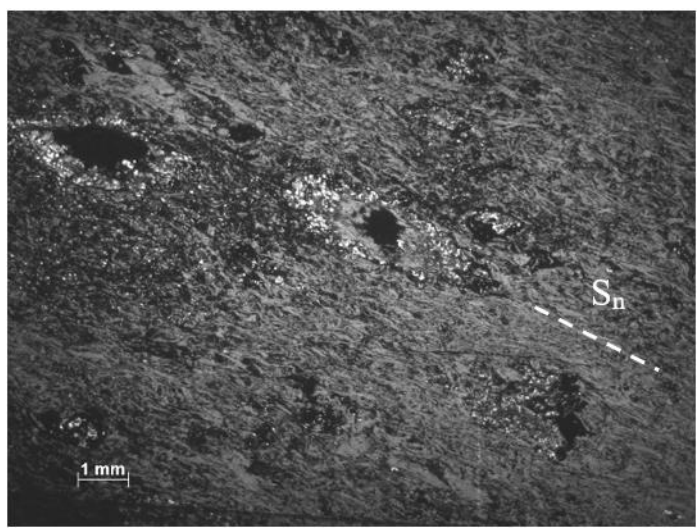

b.
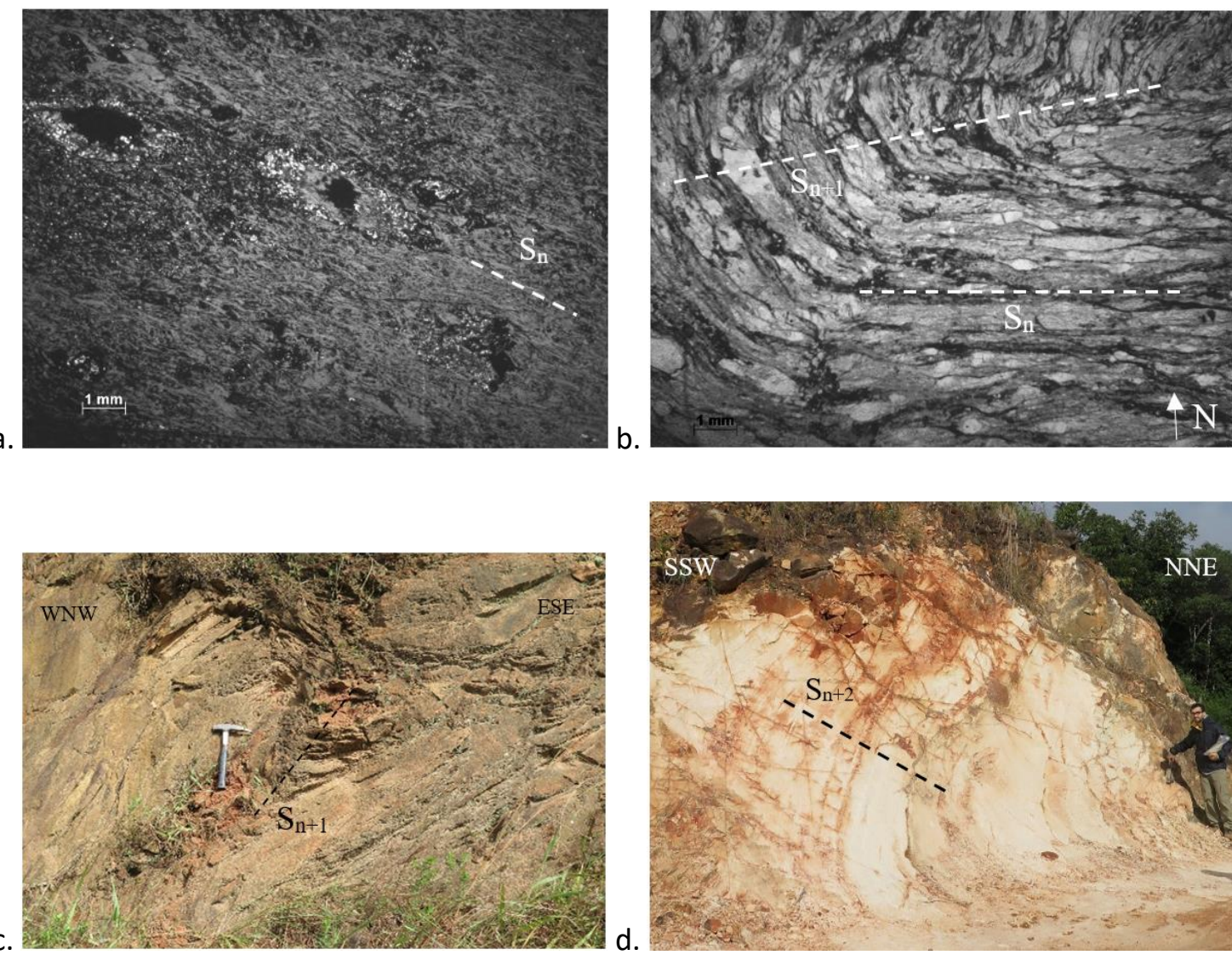

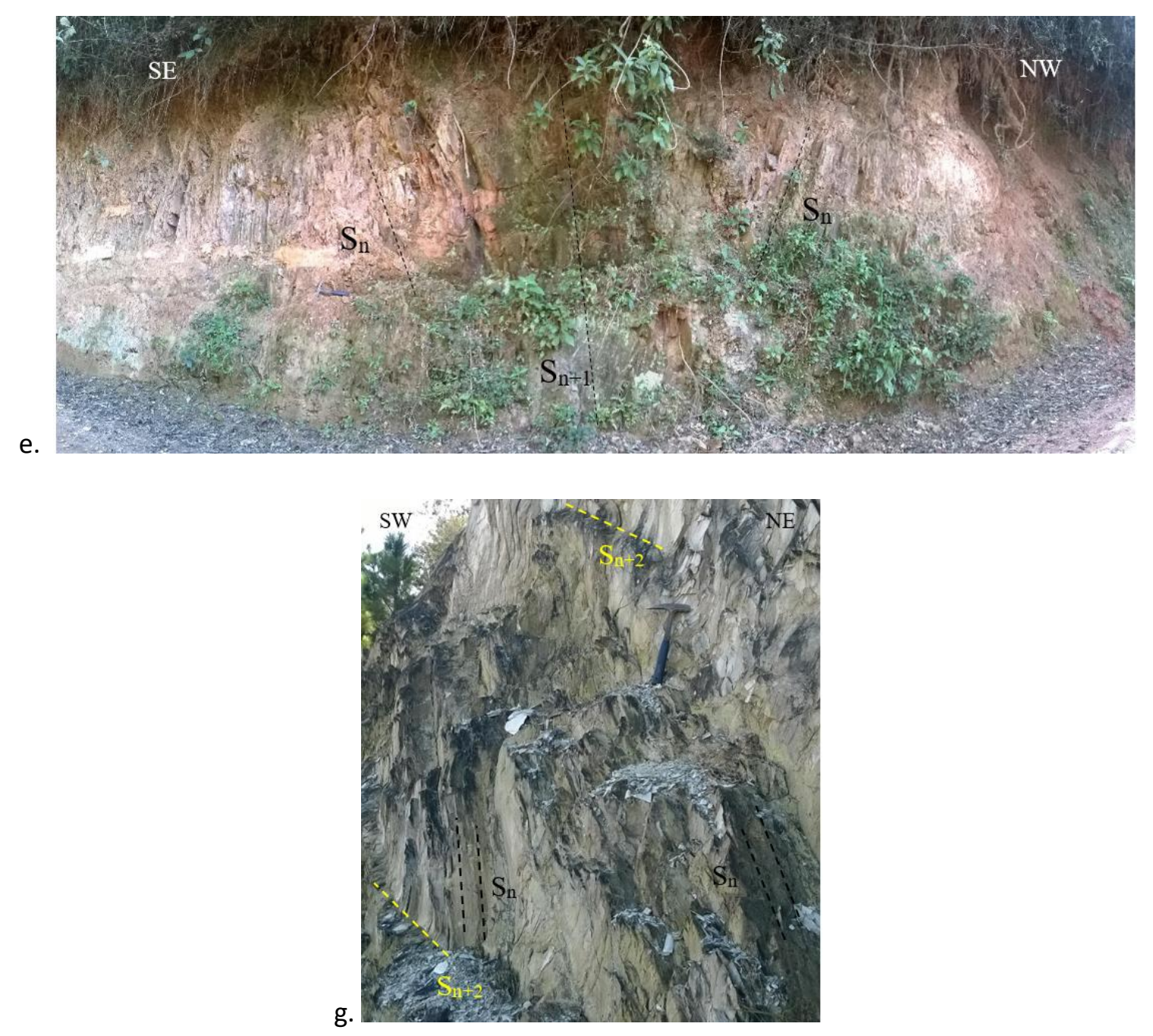

Figure 2. 19. Examples of macro and micro folding of the Sn planes from the $D_{n+1}$ deformational event and generation of $\mathrm{S}_{\mathrm{n}+1}$ cleavage: (a) Amygdales in a metavolcanosedimentary rock stretched parallel to the $S_{n}$ planes. (b) Tight fold deforming the $S_{n}$ and with a axial-plane $S_{n+1}$. (c) Tight fold with subhorizontal axis in quartzite with axial plane defined by $S_{n+1}$. (d) Open fold with axial plane delineating by $S_{n+2}$. (e) Tight fold with axial plane subvertical and subhorizontal axis affecting the $S_{n}$ and with a axial-plane $S_{n+1}$ and (f) open folds in pelitic sequence with axial plane $S_{n+2}$.

\subsubsection{Kinematic indicators}

The NNE-SSE and NNW-SSE faults are responsible for the lateral non-continuity of the rock bodies, mainly of the hills comprised of quartzite. Generally, the foliation dip and intensity increase near these faults, sometimes creating S-C structures in foliation planes and brittle deformation in quartz veins (Figure 2.20). 


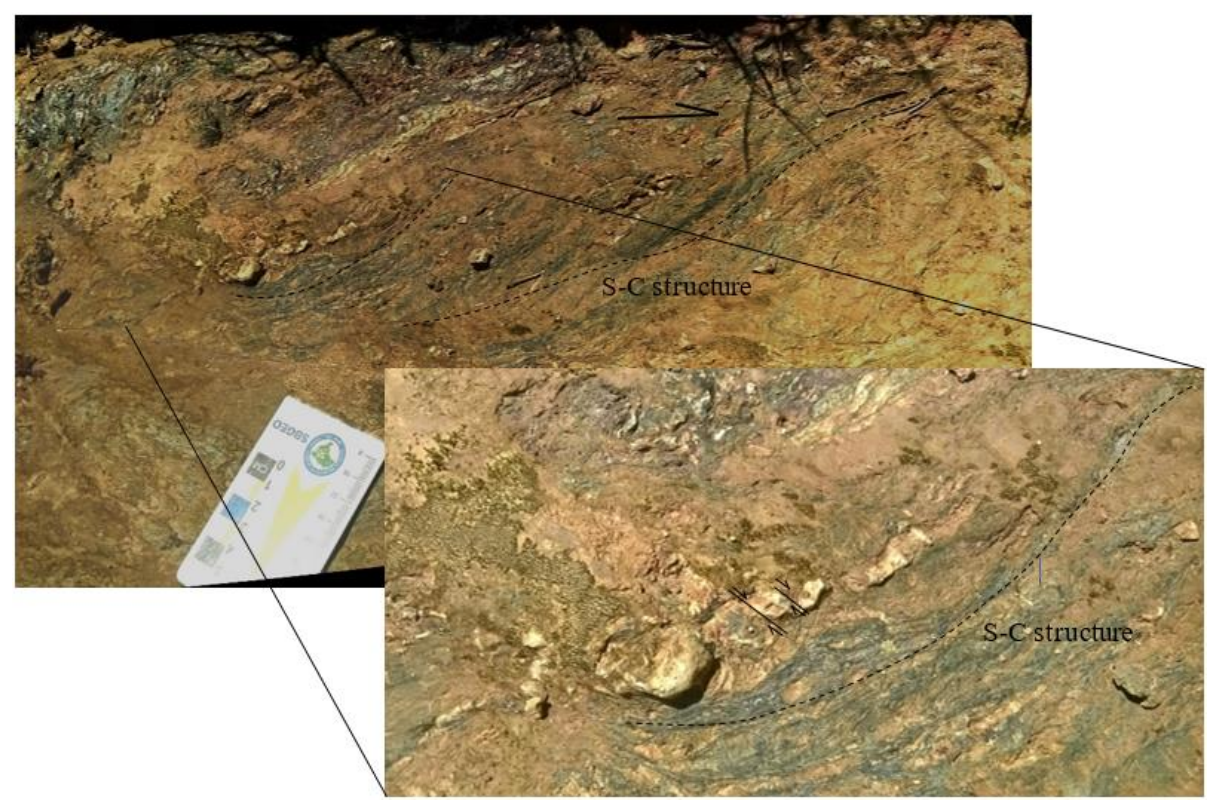

Figure 2. 20. Outcrop of gray phyllite located some meters of a NE-SW fault trace, showing dextral shear sense from kinematic indicators as the S-C structures and synthetic microfaults present in the quartz vein.

The kinematic indicators identified in thin sections subparallel to the $\mathrm{XZ}$ planes are: shear band type fragmented porphyroclasts (Passchier and Trouw, 2005; Figure 2.21a), S-C structures mainly $C^{\prime}$-type shear bands (Figure 2.21b), $\sigma$ and $\delta$ porphyroclasts (Passchier and Trouw, 2005) developed in quartz crystals (Figure 2.21c-d), and some crystal with lattice preferred orientation. They suggest dextral (Figure 2.21a-b) and sinistral shear (Figure 2.21c-d) sense for NNE-SSW and NNW-SSE faults, respectively, concordant with the field observations.

a.

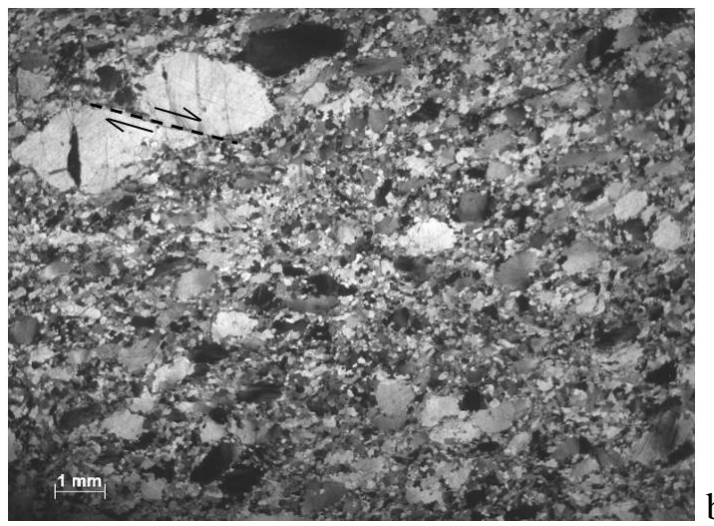

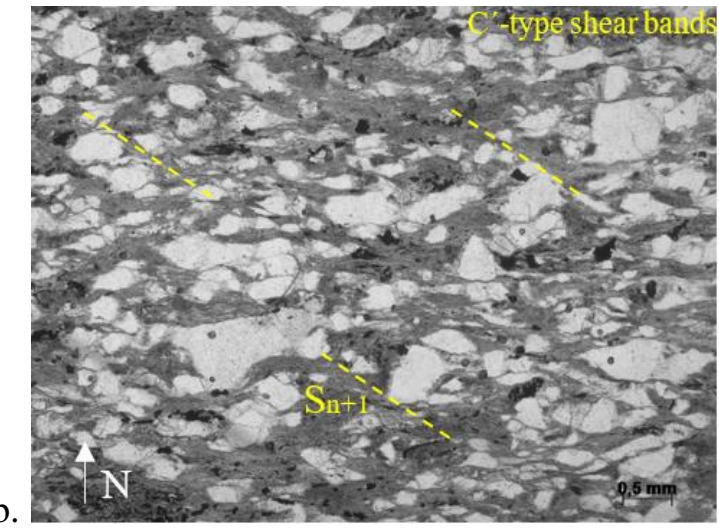



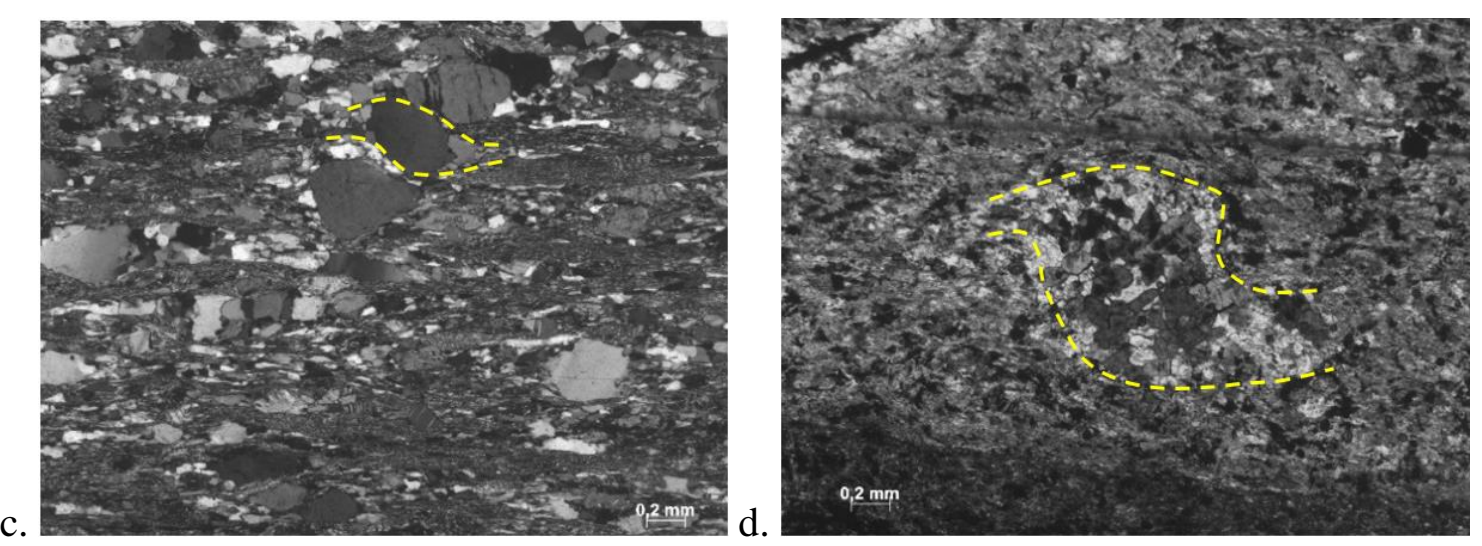

Figure 2. 21. Dextral shear sense determinate from: (a) microfaults in quartz crystals and (b) $C^{\prime}$-type shear bands in quartzites and of sinistral movement suggested by $\sigma$ porphyroclasts developed in: (c) Quartz crystal and (d) aggregates of quartz and biotite.

\subsection{CONCLUSIONS}

The presented Geological Map is the integration result of field work and interpretation of aerial photographs, digital elevation models, aerogeophysical (magnetometric and gamaspectometric) maps and satellite images, as well the reinterpretation of previously published maps.

The new 1:25,000 Geologic Map between Itapeva and Ribeirão Branco region (SP) displays eleven lithostratigraphic units: Quaternary Alluvial deposits, Mesozoic diabase dykes, sedimentary rocks of Paraná Basin (Itararé Group), Apiaí-Guaçu Metasandstone, Três Córregos Granitic Suite (Ribeirão Branco Granite), Itaiacoca Group (that includes the Serra dos Macacos Formation, Fazenda Velha Metabasic Suite, Água Nova Formation and Bairro dos Campos Formation), Bairro dos Prestes Formation and Apiaí Mirim Complex, as well the structural features as the NE-SE and NNE-SSW to NNW-SSE strike-slip faults .

It is hoped that this work will contribute to the understanding of regional geological evolution but also will serve as a base map for a varied range of applications such as mining, land use and occupation, engineering and environmental studies. 


\title{
CHAPTER 3
}

\section{Ediacaran (570-615 Ma) back-arc basin basaltic volcanism in the Itaiacoca Group, Ribeira Belt, Brazil: a remnant of the Adamastor Ocean ${ }^{1}$}

\begin{abstract}
The Itaiacoca Group comprises a metasedimentary-metavolcanic rock succession considered a major constituent of the Apiaí Terrane (southern Ribeira Belt, Brazil), and was involved in the Brasiliano-Pan African Orogeny and Gondwana assembly. Geological data, including bodies of metabasalt covered by stromatolitic dolomite, suggest the existence of oceanic islands and associated shallow water deposits. Magmatic zircon grains extracted from samples of metabasalt and metatuff yield SHRIMP U-Pb ages of $571 \pm 25$ and $613 \pm 10 \mathrm{Ma}$. Based on the chemical composition, the metabasites are classified as basalt and basaltic andesite of tholeiitic and calc-alkaline series. Trace element data indicate a geochemical signature transitional between MORB and island-arc basalts, a characteristic of back-arc basin basalts. These include flat to slightly fractionated REE patterns $\left(\mathrm{La}_{\mathrm{cn}} / \mathrm{Yb}_{\mathrm{cn}}\right.$ of $\left.0.9-1.9\right)$, Ti/V ratios of $16-27$, depletion of HSFE and enrichment in LILE relative to MORB values. $\varepsilon \mathrm{N}_{\mathrm{d}(\mathrm{t})}$ values from +2.3 to +3.2 indicate a dominant juvenile mantle source. Overall geochemical patterns indicate a MORBtype mantle source with contribution of the subduction components. Geological data allowed the recognition of a Statherian unit (Bairro dos Prestes Formation), previously interpreted as a part of the Itaiacoca Group. It comprises a succession of phyllite interbedded with layers of quartzite and restricted metaconglomerate and felsic metavolcanic rocks. Zircon SHRIMP U$\mathrm{Pb}$ data yield a Concordia age of $1761 \pm 14 \mathrm{Ma}$ for a metarhyodacite with high-K calc-alkaline signature, while detrital zircons from a metavolcanosedimentary sample give youngest age of $\sim 1800 \mathrm{Ma}$. Geological and geochronological data suggest that the Itaiacoca Group and Bairro dos Prestes Formation can be correlated with the Pirapora do Bom Jesus and Boturuna Formations of the São Roque Group. The Itaiacoca Group is inferred as a remnant of an arcback-arc basin system associated with the Adamastor Ocean, and an Ediacaran suture zone between the Apiaí Terrane and the Paranapanema Craton.
\end{abstract}

Key words: Itaiacoca Group; Bairro dos Prestes Formation; Geochemistry; Geochronology; Metabasites; Metarhyodacite; Apiaí Terrane; Ribeira Belt

${ }^{1}$ Forero-Ortega, A.J., Campanha, G.A.C., Faleiros F.M. 


\subsection{INTRODUCTION}

Recent works have shown that the tectonic arrangement of the Ribeira Belt is complex, with juxtaposition of several distinct lithotectonic units including Paleoproterozoic orthogneisses of varied geochemical signatures, sedimentary basins with depositional ages varying from the Statherian to the Ediacaran, and Tonian to Ediacaran magmatic rocks of arc and extensional settings, all affected by Ediacaran regional deformation and metamorphism and a late crustalscale transcurrent shear zone system (Soares, 1987; Reis Neto, 1994; Campanha and Sadowski, 1999; Janasi et al., 2001; Prazeres Filho, 2005; Siga Jr et al., 2009, Faleiros et al., 2010, 2011a, 2016; Salazar et al., 2013; Henrique-Pinto et al., 2015). The depositional environments of Neoproterozoic, Mesoproterozoic and Paleoproterozoic successions are contentious, including aulacogen basin, passive margin continental platform, subduction setting, arc island, rifted continental margin, intra-arc basin, fore-arc and back-arc basin (Campanha, 1987; Campanha and Sadowski, 1999; Siga et al.,2009, 2011a, 2011b, 2011c; Faleiros et al., 2011b, 2016). Paleogeographic reconstructions are difficult due to the lack of continuity of units and the superimposed deformational and metamorphic events, and new geochronological and geochemical data are necessary to help to understand the Ribeira belt geological evolution.

The Itaiacoca Group (Almeida, 1956) comprises a succession of metasedimentary and metavolcanic rocks that is considered a major constituent of the Apiaí Terrane in southern Ribeira Belt, south-southeastern Brazil. Its tectonic setting and depositional age has been subject of discussion. Geochronological data obtained in metacarbonatic and metavolcanic succession in the southwestern portion of the Itaiacoca Group (Siga Jr et al., 2003, 2010, 2011c; Siga Jr, 2009) define two lithotectonic units related with extensional (1030-900 Ma) and compressional (645-628 Ma) tectonic environments. On the other hand, Fairchild (1977) suggests from stromatolite structures, Neoproterozoic to Paleoproterozoic ages for the deposition. The possible environment for the sedimentation of Itaiacoca Group has been inferred based on its sedimentary structures and petrographic character of its metavolcanics rocks, mainly contextualized in extensional settings (e.g. Petri and Suguio, 1969; Hasui et al., 1984b; Chiodi Filho, 1983; Takahashi et al., 1984; Theodorovicz et al., 1988; Souza, 1990, 1992; Campanha, 1991; Sallun Filho, 1999; Trein et al., 1985; Reis Neto, 1994), in which the magmatic rocks present tholeiitic, shoshonitic and calc-alkaline signatures (Theodorovicz et al., 1986; Trein et al., 1985; Reis Neto, 1994). 
We present a geochemical and geochronological characterization of metavolcanic rocks from the Itaiacoca Group on a key-area in its north-easternmost portion, through field geological mapping, U-Pb SHRIMP data in zircon, and elemental and Sm-Nd isotope geochemistry. The data are used to (1) determinate the depositional age of the Itaiacoca Group, (2) define the possible setting of rock deposition and emplacement and the regional correlation with other formations, (3) contribute to possible paleogeographic reconstructions for the Ribeira Belt with their implications to the assembly history of Gondwana.

\subsection{REGIONAL GEOLOGICAL SETTING}

The Ribeira Belt is constituted by allochthonous blocks of Archean to Paleoproterozoic basement rocks, Mesoproterozoic to Neoproterozoic metasedimentary rocks and granitoid plutonic rocks with sin to post-tectonic character agglutinated in the Brasiliano/Pan African Orogeny in the Neoproterozoic (e.g., Almeida et al., 1973; Hasui et al., 1975; Brito Neves et al., 1999; Campanha and Sadowski, 1999; Cordani et al., 2003; Heilbron et al., 2004; Campanha et al., 2015, 2016). Its late evolution was tectonically controlled by strike-slip shear zones (Campanha, 2002; Siga Jr, 2010; Faleiros et al., 2010, 2011b, 2016). The southwestern portion of this NE-trending belt subparallel to the southeastern coast of Brazil is divided by the Lanchinha-Cubatão fault zone in two main domains: the Curitiba and Apiaí terranes (Figure $3.1)$.

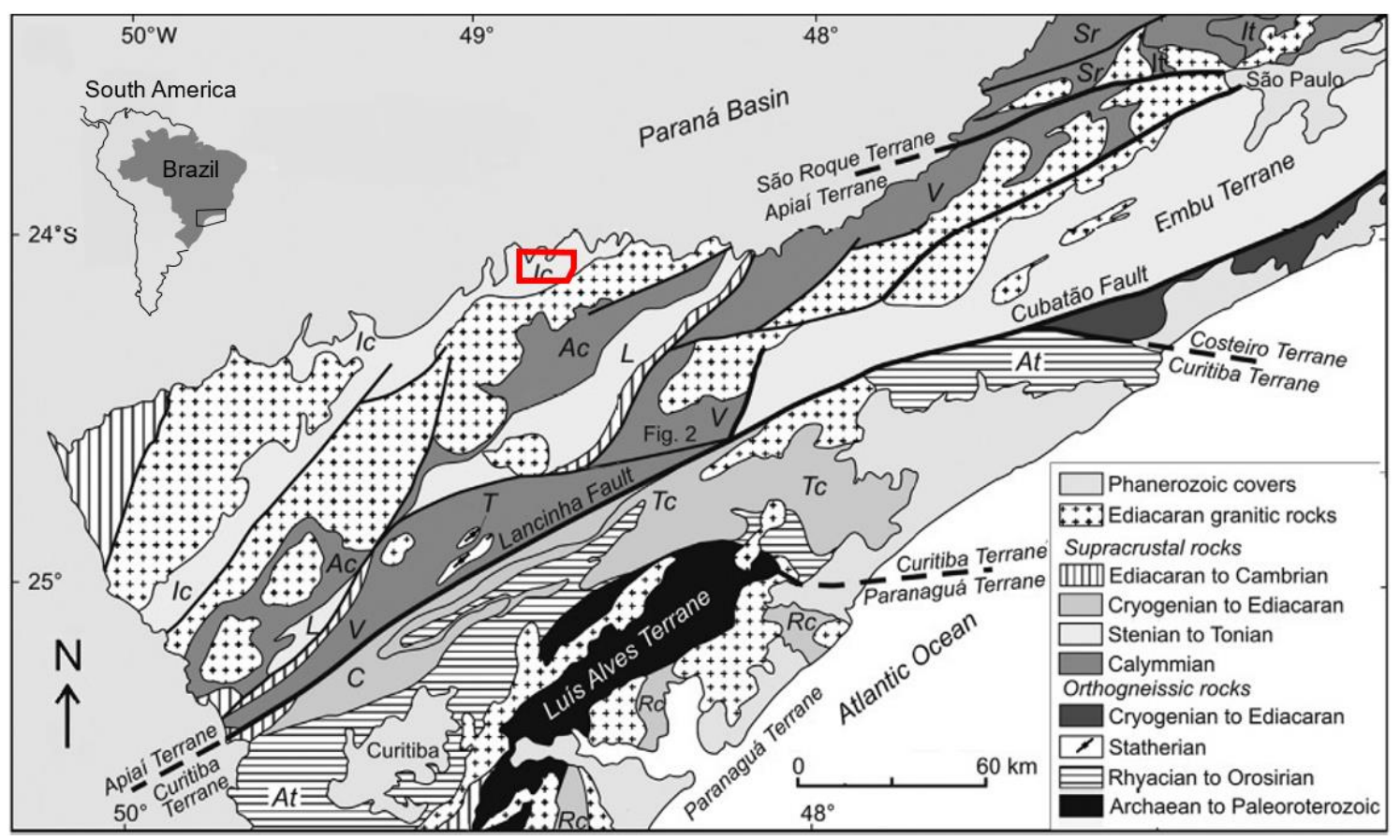

Figure 3. 1. Simplified geotectonic map of the Southwestern portion of the Ribeira Belt with location of study area Figure 3.2. (From Campanha et al., 2015). 
The Apiaí Terrane is a composite terrane inferred as formed by the collage of units of very distinct ages and tectonic settings, including remnants of continental passive margins, carbonatic platforms, flysh-type deposits, ocean floor, island arc, back-arc, intra-arc and subduction zone rocks, which were juxtaposed by the deformation caused by shear zones (Heilbron et al., 2004; Campanha and Faleiros, 2005; Faleiros, 2008; Faleiros et al., 2011b), created sigmoidal lenses and displacement and rupture of the stratigraphic units, hindering their lateral correlations (Faleiros, 2008). Restricted basement orthogneisses present in the Apiaí Terrane are records of magmatic events occurred in the Statherian (1800-1750 Ma; Kaulfuss, 2001; Cury et al., 2002; Prazeres Filho, 2005;), while metasedimentary and metavolcanic rock associations primarily belong to Calymmian units (1600-1450 Ma; Weber et al., 2003; Basei et al., 2008; Campanha et al., 2008a; Siga Jr et al., 2011a, 2011b; Campanha et al., 2015a, 2015b). Compressional regime (sedimentation in restricted basins) are registered in the Tonian (1000900) and Ediacaran (630-573 Ma) (Campanha et al., 2008; Siga Jr et al., 2009). During the Ediacaran, the Apiaí and Curitiba terranes were also intruded by extensive bodies of arc-related magmatic rocks as the granitoid suites Cunhaporanga, Três Córregos and Agudos Grandes (Gimenez Filho, 1993; Gimenez Filho et al., 1995; Reis Neto, 1994; Campanha and Sadowski, 1999; Janasi et al., 2001; Prazeres Filho, 2005).

\subsubsection{The Itaiacoca Group}

The Itaiacoca Group (Figure 3.1) was initially defined by Almeida (1956), and it would be part, according to different authors of the Açungui Group (Hasui et al. 1984; Bistrichi 1985), Itapeva belt (Hasui et al., 1984a), Itaiacoca-Itapeva belt (Chiodi Filho, 1983, 1984) or the Itaiacoca belt (Reis Neto, 1994; Siga Jr et al., 2009). The Itaiacoca belt (sensu lato) is composed of Proterozoic rocks oriented in NE-SW-trend, located between the Cunhaporanga and Três Córregos granitic batholiths from Ponta Grossa city (Paraná State) to Itapeva city (São Paulo State). Geological mapping works performed at regional to semi-detailed scales (Chiodi, 1983, 1984; Takahashi et al., 1984; Bistrichi, 1985; Trein et al., 1985; Theodorovicz et al 1986, 1988; Soares, 1987a, 1987b; Santoro and frascá, 1989; Souza, 1990, 1992; Reis Neto, 1994; Prazeres Filho et al., 1998; Campanha and Sadowski, 1999, Siga Jr 2010) used different nomenclatures the formations that make up the Itaiacoca Group. We assume with some modifications the stratigraphic scheme of Souza $(1990,1992)$ for the division of Itaiacoca Group. He identified four formations: Serra dos Macacos, Bairro dos Campos, Água Nova and Bairro da Estiva, the last is not present in the studied area. 
The deposition of the Itaiacoca Group has been interpreted as related with different tectonic settings, including deposits of tidal plain environment close to the coast (Petri and Suguio, 1969), grabens and rifts with formation of elongated and restricted basins (Hasui et al., 1984b, 1986), aulacogen basins (Chiodi Filho, 1983, 1984), continental shelf developed in a rifted continental margin basin (Takahashi et al., 1984, Theodorovicz et al., 1988; Souza, 1990, 1992; Campanha, 1991; Frascá, 1992; Sallun Filho, 1999), sedimentation in a relatively deep depositional setting, sub-coast and below fair-weather wave base (Sallun Filho and Fairchild, 2000, 2004, 2005), intra arc basin (Soares, 1987a, 1987b), Andean type (Campanha et al., 1987) and B type subduction settings (Theodorovicz and Câmara, 1988), delta systems (Trein et al., 1985), arc island (Campanha, 2002) and passive margin developed on a stable region (Reis Neto, 1994; Campanha and Sadowski, 1999).

The Itaiacoca Group was affected by a greenschist facies regional metamorphism (Trein et al., 1985; Campanha et al., 1987; Soares, 1987a, 1987b; Souza, 1990; Reis Neto, 1994). In addition, the occurrence of talc and serpentine bands in dolomites suggests metasomatic events associated with the intrusion of Mesozoic diabase dykes (Souza, 1990; Frascá, 1992; Reis Neto, 1994; Szabó et al., 2006; Andrade, 2008) or regional fault-related fluid circulation (Saunite et al., 2011).

Geochemical data of the igneous rocks (basic volcanic, ultrabasic and subvolcanic felsic rocks) of the Itaiacoca Group reveal bimodal (Takahashi et al., 1984; Theodorovicz et al., 1988), tholeiitic, calc-alkaline and shoshonitic signature components (Trein et al., 1985; Theodorovicz et al., 1986; Reis Neto, 1994).

Age data for Itaiacoca Group rocks are scarce and ambiguous. Almeida (1956) and Fairchild (1977) recognized Conophyton garganicum type stromatolites, suggesting Tonian to Statherian ages (between 850 to $1700 \mathrm{Ma}$ ) for the Itaiacoca Group. Metabasite and marble samples from the Abapã and Bairro dos Campos formations gave imprecise $\mathrm{Pb}-\mathrm{Pb}, \mathrm{Rb}-\mathrm{Sr}$ and $\mathrm{Sm}-\mathrm{Nd}$ average ages within the interval 1250-1080 Ma (Reis Neto, 1994). Zircon U-Pb data yield ages of 1030$900 \mathrm{Ma}$ for metabasites from the Bairro dos Campos Formation and 645-628 Ma for metarhyolites from the Abapã Formation (Siga Jr et al., 2009). 


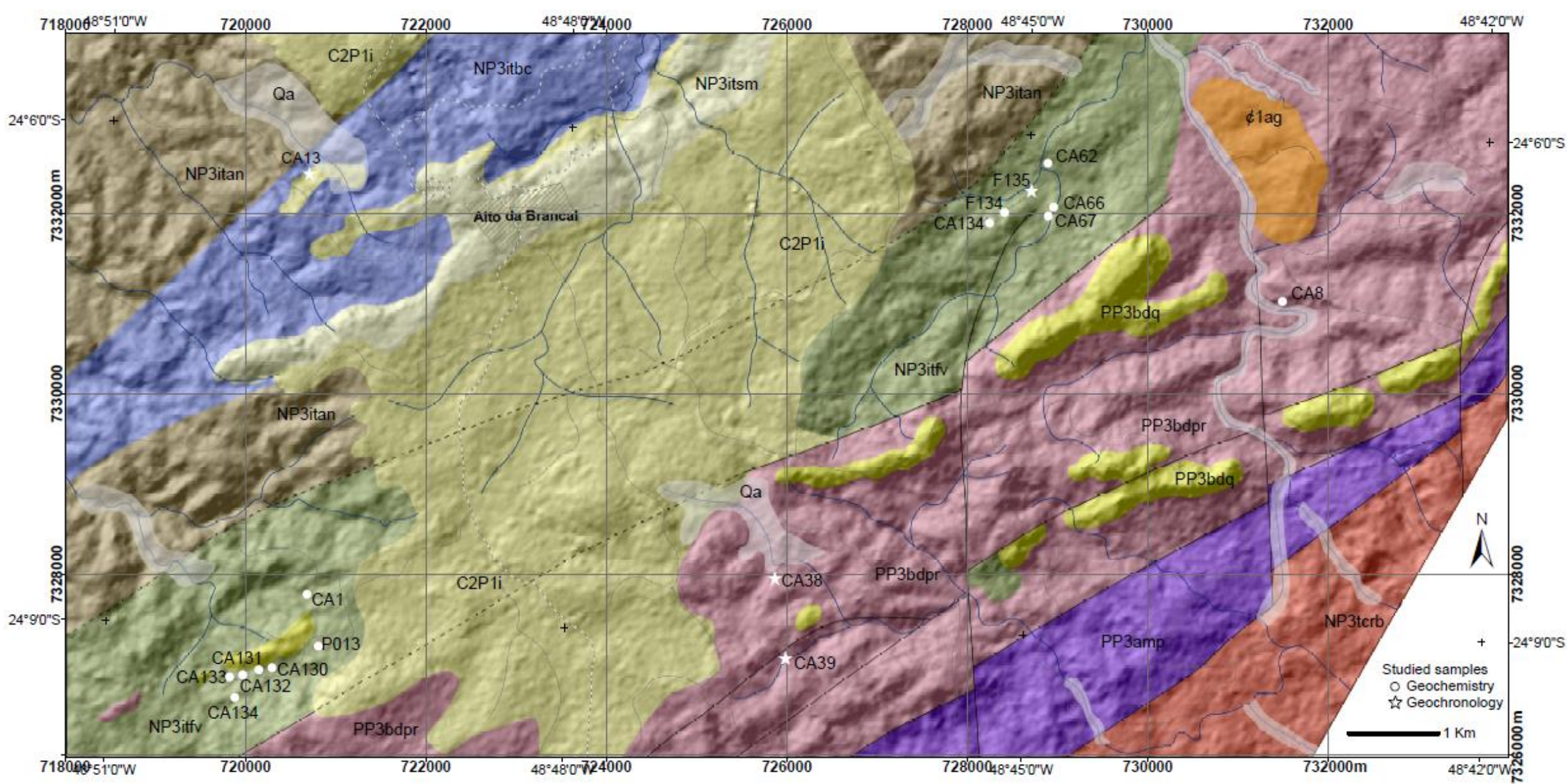

Figure 3. 2. Geological map of the studied area. Itararé Group (C2P1i), Apiaí-Guaçu metasandstone ( $\phi 1$ ag), Ribeirão Branco granite (NP3tcrb); Itaiacoca Group: Serra dos Macacos Formation (NP 3itsm), Fazenda Velha Metabasic Suite (NP 3itfv), Água Nova Formation (NP3itan) and Bairro dos Campos Formation (NP3itbc), Bairro dos Prestes Formation: phyllite (PP3bdpr) with intercalations of quartzites (PP3bdq) and Apiaí Mirim Complex (PP3amp). The analyzed samples are georeferenced to Universal Transverse Mercator coordinate system (WGS 84 Horizontal Datum, 22S zone). 


\subsubsection{Local Geology}

\subsubsection{Itaiacoca Group}

The Itaiacoca Group in the studied area (Figure 3.2) consists in a succession of metamudstone, phyllites and fine-grained quartzites (Água Nova Formation), intercalated with calcitic and dolomitic metalimestone with stromatolite structures and small beds of metatuff (Bairro dos Campos Formation) in transition contact with mainly metabasites, metadolomites, talc schists and chlorite schists (Fazenda Velha Metabasic Suite), and massive quartzites (Serra dos Macacos Formation) overlapping all the units

The Fazenda Velha Metabasic Suite, definition proposed here, is composed of metabasalts and metagabbro with green to dark green colors. These rocks preserve reliquiar igneous textures (subophitic and ophitic textures), and are composed of augite, plagioclase, epidote, clinozoisite, quartz, carbonates, sericite-epidote aggregates, oxides (titanomagnetite, rutile and ilmenite) and other minor opaque minerals. Pseudomorphs of chemically zoned pyroxene were replaced by chlorite aggregates in core domains, reflecting higher content of $\mathrm{Mg}$ (pigeonite), and actinolite aggregates on the edges (augite) (Figure 3.3b).

a.

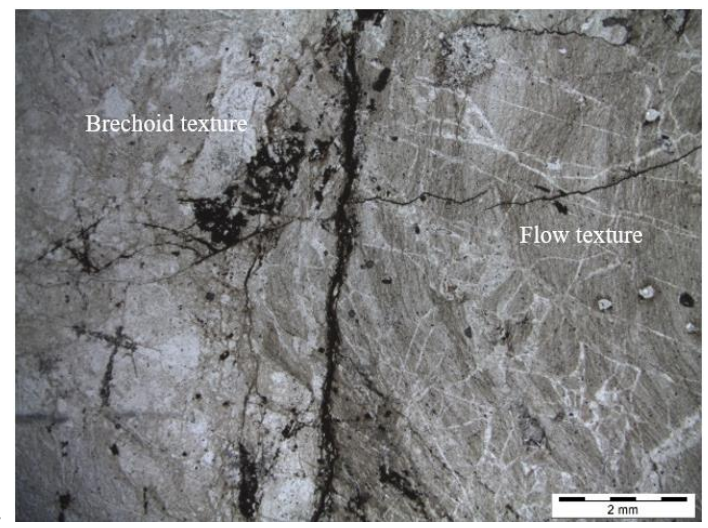

b.

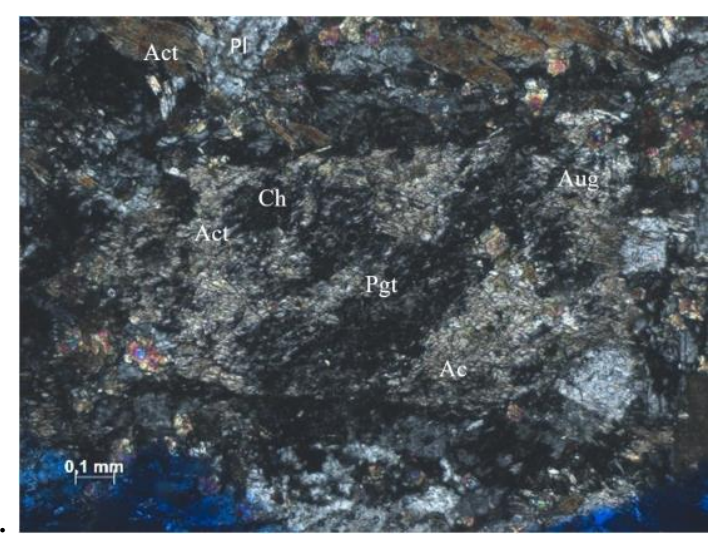

Figure 3. 3. Photomicrography under cross and plane polarized light optical of (a) flow and brechoid textures of the metatuff rocks and (b) metabasite sample showing pseudomorphs of pyroxene.

A metatuff sample was collected at the Água Nova and Bairro dos Campos formations contact. Petrographically, it displays flow texture (Figure 3.3a) with anedric quartz grains, irregular feldspar fragments and titanite, supported by a fine-grained matrix of epidote, chlorite, sericite and opaque minerals. 


\subsubsection{Bairro dos Prestes Formation}

The Bairro dos Prestes Formation was previously considered as an undivided part of the Itaiacoca Group (Takahashi et al., 1984; Theodorovicz et al., 1988), but geological and geochronological (see below) data obtained here supports their dismemberment. The Bairro dos Prestes Formation is composed of phyllites in transitional contact with fine to medium-grained quartzites, with restricted outcrops of metarhyodacite and metaconglomerate.

The phyllites present lepidoblastic textures and are composed of varied amounts of muscovite, biotite, quartz and feldspar, with accessory tourmaline, rutile, zircon and apatite. A slaty cleavage is pervasive over the whole unit and was heterogeneously superposed by a crenulation cleavage associated with open to tight folds. Amygdaloidal textures are locally preserved (Figure 3.4a), suggesting a volcanogenic origin for at least for part of the unit.

The quartzites are composed of quartz with minor plagioclase, muscovite, microcline and biotite contents.
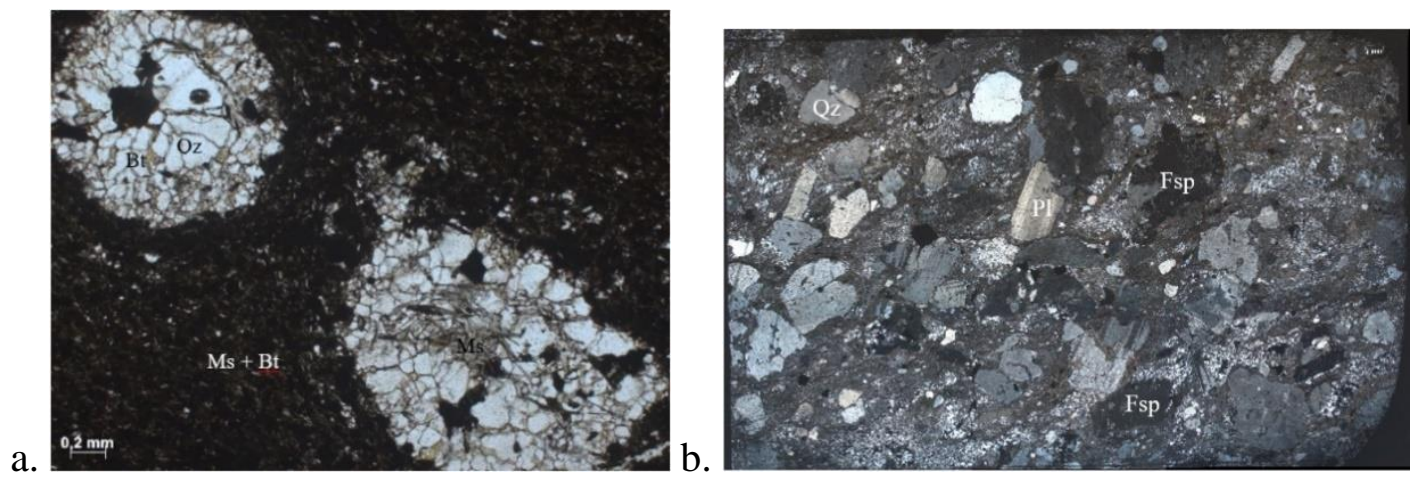

Figure 3. 4. Thin sections of phyllite exhibit (a) millimetric vacuoles and (b) metarhyodacite sample (under plane-polarised light).

A metarhyodacite outcrop was observed as a restricted rock bodies but similar occurrences were also described by Theodorovicz et al. (1988). The rock is heterogeneously foliated, with porphyritic to porphyroclastic texture, and is in a concordant contact with phyllites keeping the foliation constant across the contact. Microscopically, the metarhyodacite show resorption and porphyroclastic structures, with phenocrystals of quartz, K-feldspar and plagioclase (Figure $3.4 \mathrm{~b}$ ) set in a fine-grained matrix of quartz, biotite, white mica, chlorite and titanite. Zircon, ilmenite and rutile are the main accessory minerals.

A metaconglomerate outcrop was observed exhibiting interdigitated contact with quartzite and phyllite intercalations. The metaconglomerate is composed of quartzite, volcanic and phyllite 
pebbles supported by a metapelitic matrix. The volcanic pebbles show deformed amygdales filled by quartz, feldspar, muscovite and biotite, supported by fine-grained matrix of sericite, biotite and opaque minerals, classified as quartz-feldspar-biotite phyllite. Some black phyllite pebbles show an internal foliation discordant from the external foliation of the metaconglomerate matrix, suggesting an erosion of a former and older phyllite source unit.

Table 3. 1. Studied samples in the geochemical analysis.

\begin{tabular}{ccccc}
\hline Sample & Unit & Type of rock & $\begin{array}{c}\text { Preserved igneous } \\
\text { minerals }\end{array}$ & $\begin{array}{c}\text { Metamorphic mineralogical } \\
\text { association }\end{array}$ \\
\hline CA1 & Itaiacoca Group & Metabasalt & & Act, Chl, Cb \\
CA8 & Itaiacoca Group & Metagabbro & Aug, Pl & Act, Chl, Ep, Czo \\
CA62 & Itaiacoca Group & Metabasalt & Pl & Act, Ep \\
CA66 & Itaiacoca Group & Metagabbro & Aug, Pl & Act, Chl, Ep, Czo \\
CA67 & Itaiacoca Group & Metagabbro & $\mathrm{Pl}$ & Act, Ep, Chl, Czo \\
CA130 & Itaiacoca Group & Metabasalt & $\mathrm{Pl}$ & Act, Ep, Chl, Czo \\
CA131 & Itaiacoca Group & Metabasalt & $\mathrm{Pl}$ & Act, Ep, Chl, Czo \\
CA132 & Itaiacoca Group & Metabasalt & $\mathrm{Pl}$ & Act, Ep, Chl, Czo \\
CA133 & Itaiacoca Group & Metagabbro & Aug, Pl & Act, Chl, Ep, Czo \\
CA134 & Itaiacoca Group & Metagabbro & Aug, Pl & Act, Chl, Ep, Czo, Qz \\
F134 & Itaiacoca Group & Metabasalt & Pl & Act, Ep, Chl, Czo \\
F135 & Itaiacoca Group & Metagabbro & Aug, Pl & Act, Chl, Ep, Czo \\
P13 & Itaiacoca Group & Metagabbro & Pl & Act, Chl, Ep, Czo \\
CA39 & Bairro dos Prestes & Metarhyodacite & Qz, Pl, Fsp, Bt, Ms & Qz, Bt, Chl, White micas \\
\hline
\end{tabular}

\subsection{ANALYTICAL METHODS}

Geochemical analyses were done to determinate the major and trace elements concentrations including rare earth elements (REEs) of 13 metabasite samples of the Itaiacoca Group and a metarhyodacite sample of the Bairro dos Prestes Formation (Table 3.1 and 3.2); they were carried out at Activation Laboratories Ltd. (Actlabs, Canada), using lithium metaborate/tetraborate fusion (ICP/WRA) for major and minor oxides, and inductively coupled plasma mass spectrometry (ICP-MS) for trace elements. Most geochemical diagrams were made using the GCDkit program version 4.1 (Janousek et al., 2006, 2011).

$\mathrm{Sm}$ and $\mathrm{Nd}$ concentrations and $\mathrm{Sm}-\mathrm{Nd}$ isotopic rations of 13 metabasite and a metarhyodacite sample (Table 3.3) measured by isotope dilution were performed at the Geochronology Research Center of the University of São Paulo (CPGeo-USP), using a TRITON multi-collector mass spectrometer; details of the analytical procedures are described in Sato et al. (1995) and 
Petronilho (2009). The ${ }^{143} \mathrm{Nd} /{ }^{144} \mathrm{Nd}$ values were normalized with ${ }^{146} \mathrm{Nd} /{ }^{144} \mathrm{Nd}=0.7219$ (De Paolo, 1981), and for $\varepsilon_{\mathrm{Nd}(0)}$ and $\mathrm{f}_{\mathrm{Sm} / \mathrm{Nd}}$ parameters were used ${ }^{143} \mathrm{Nd} /{ }^{144} \mathrm{Nd}$ CHUR $=0.512638$ (Hamilton et al., 1983) and ${ }^{147} \mathrm{Sm} /{ }^{144} \mathrm{Nd}_{\mathrm{CHUR}}=0.1967$ (Hamilton et al.1983), respectively. Calibration of replicate analyses was done with Jndi-1 standard (Tanaka et al., 2000).
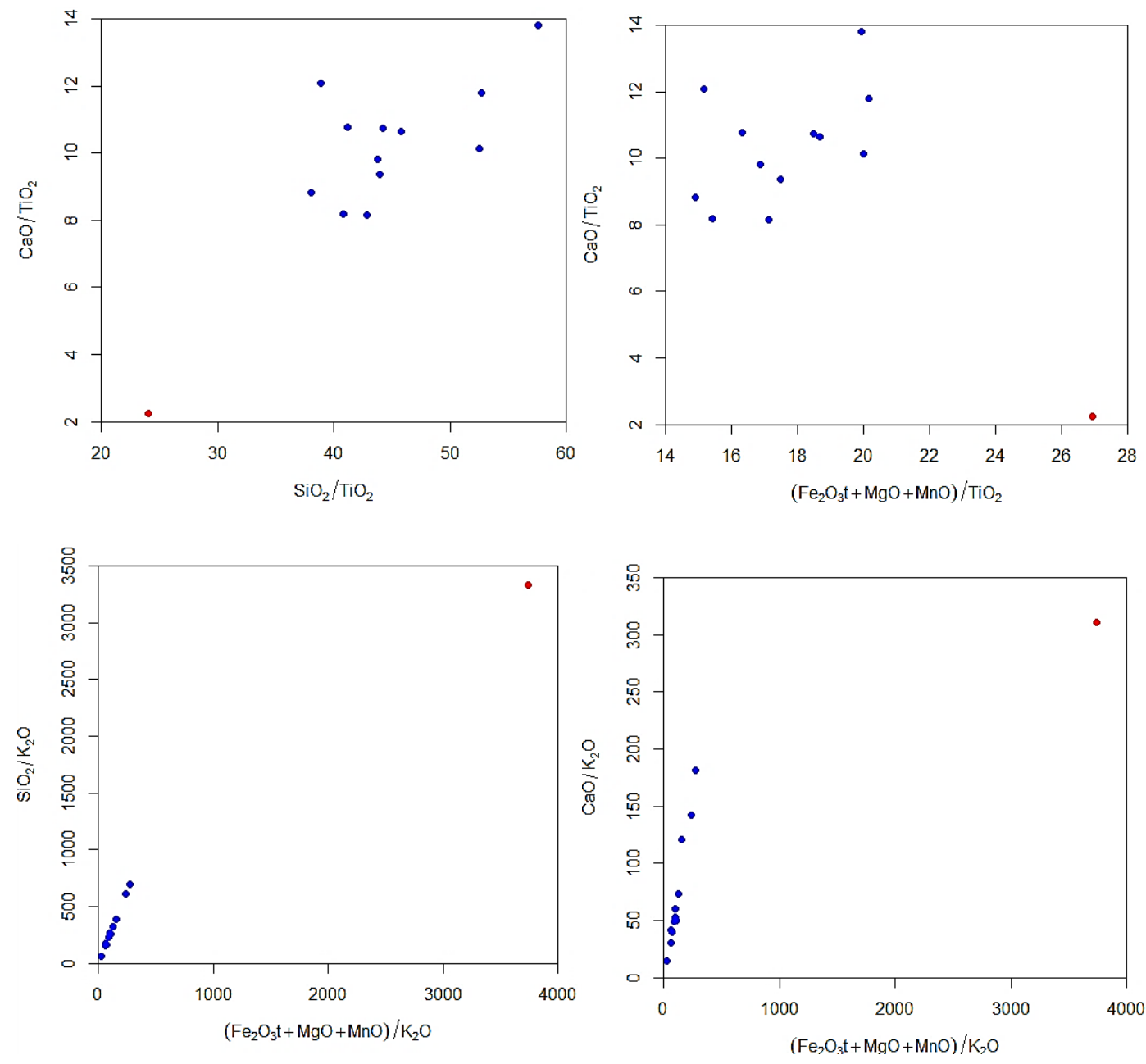

Figure 3. 5. Diagrams of the ratios of molecular proportions for metabasites from the Fazenda Velha Metabasic Suite of the Itaiacoca Group. In red, the CA1 sample.

The zircons grains were analyzed by U-Pb SHRIMP method. They were separated from 100200-mesh fractions following the standards and techniques developed at the CPGeo-USP, which included granulometric reduction, Wiffley table, electromagnetic (FRANTZ) and density (bromoform and methylene iodide dense liquids) separation. Zircon grains preferably without fractures and physical characteristics evidencing $\mathrm{Pb}$ loss were hand-picked using a binocular microscope, and subsequently set with the TEMORA 2 standard in a circular epoxy resin mount, to be polished exposing crystals half-sections. Reflected light and cathodoluminescence (CL) imagens were acquired in order to choose the most suitable position of the zircon (no inclusions or metamict domains) for the $\mathrm{U}-\mathrm{Pb}$ isotopic analysis. 
Table 3. 2. Major and trace element geochemical data for metabasites from the Fazenda Velha Metabasic Suite of the Itaiacoca Group and metarhyodacite of Bairro dos Prestes Formation. Oxides in wt.\%, trace elements in ppm and geographical coordinates in decimal degrees (WGS-84 datum).

\begin{tabular}{lllllllllllllll}
\hline Sample & CA1 & CA8 & CA62 & CA66 & CA67 & CA130 & CA131 & CA132 & CA133 & CA134 & F134 & F135 & P13 & CA39 \\
Longitude (W) & 48.8300 & 48.7240 & 48.7501 & 48.7493 & 48.7499 & 48.8338 & 48.8351 & 48.8371 & 48.8384 & 48.7569 & 48.7547 & 48.7518 & 48.8289 & 48.776 \\
Latitude (S) & 24.1481 & 24.1171 & 24.1034 & 24.1079 & 24.1088 & 24.1554 & 24.1557 & 24.1561 & 24.1563 & 24.1098 & 24.1088 & 24.1065 & 24.1531 & 24.1526 \\
\hline SiO2 & 32.95 & 47.97 & 47.14 & 48.1 & 48.67 & 49.97 & 49.6 & 49.86 & 48.65 & 48.47 & 46.9 & 48.97 & 48.34 & 64.56 \\
Al203 & 14.97 & 13.84 & 14.3 & 14.71 & 13.66 & 14.39 & 13.92 & 14.53 & 14.06 & 16.43 & 15.15 & 13.78 & 13.91 & 13.19 \\
$\mathrm{Fe} 203$ & 14.91 & 11.25 & 12.22 & 10.94 & 12.12 & 12.4 & 12.73 & 12.13 & 11.56 & 9.32 & 11.79 & 12.44 & 11.54 & 4.14 \\
$\mathrm{MnO}$ & 0.226 & 0.19 & 0.168 & 0.148 & 0.158 & 0.179 & 0.18 & 0.166 & 0.161 & 0.154 & 0.151 & 0.16 & 0.182 & 0.04 \\
$\mathrm{MgO}$ & 21.82 & 7.64 & 7.33 & 7.29 & 6.98 & 6.32 & 6.94 & 6.69 & 7.03 & 7.29 & 6.34 & 6.59 & 7.99 & 2.22 \\
$\mathrm{CaO}$ & 3.07 & 10.22 & 11.43 & 10.73 & 12.74 & 10.02 & 9.45 & 9.62 & 10.94 & 11.66 & 14.54 & 11.34 & 11.25 & 2.13 \\
$\mathrm{Na} 20$ & 0.03 & 3.39 & 2.15 & 3.22 & 2 & 3.41 & 3.33 & 3.29 & 3.3 & 3.02 & 2.03 & 2.91 & 2.02 & 2.08 \\
$\mathrm{~K} 20$ & 0.01 & 0.21 & 0.29 & 0.18 & 0.07 & 0.19 & 0.19 & 0.32 & 0.15 & 0.28 & 0.12 & 0.08 & 0.79 & 5.89 \\
$\mathrm{TiO} 2$ & 1.368 & 1.089 & 1.068 & 0.915 & 1.183 & 1.222 & 1.16 & 0.953 & 1.113 & 0.842 & 1.21 & 1.284 & 1.056 & 0.511 \\
$\mathrm{P} 205$ & 0.1 & 0.08 & 0.08 & 0.09 & 0.08 & 0.08 & 0.06 & 0.06 & 0.07 & 0.05 & 0.09 & 0.09 & 0.03 & 0.09 \\
$\mathrm{LOI}$ & 9.29 & 4.21 & 3.56 & 3.34 & 2.45 & 2.24 & 2.31 & 2.4 & 2.29 & 2.69 & 2.19 & 2.15 & 2.51 & 3.77 \\
$\mathrm{Total}$ & 98.75 & 100.1 & 99.73 & 99.66 & 100.1 & 100.4 & 99.88 & 100 & 99.33 & 100.2 & 100.5 & 99.79 & 99.61 & 98.63 \\
$\mathrm{Ba}$ & 3 & 41 & 76 & 42 & 13 & 34 & 31 & 52 & 38 & 35 & 26 & 12 & 134 & 1428 \\
$\mathrm{Rb}$ & $<1$ & 4 & 5 & 3 & $<1$ & 2 & 2 & 4 & 3 & 5 & $<1$ & $<1$ & 11 & 134 \\
$\mathrm{Sr}$ & $<2$ & 156 & 148 & 183 & 166 & 144 & 146 & 162 & 142 & 145 & 162 & 140 & 193 & 46 \\
$\mathrm{Zr}$ & 71 & 57 & 76 & 64 & 65 & 57 & 45 & 39 & 47 & 42 & 60 & 72 & 29 & 471 \\
$\mathrm{Sc}$ & 46 & 40 & 38 & 32 & 37 & 43 & 42 & 39 & 43 & 36 & 39 & 42 & 44 & 8 \\
$\mathrm{Ga}$ & 22 & 18 & 22 & 20 & 20 & 20 & 21 & 20 & 19 & 18 & 26 & 21 & 18 & 22
\end{tabular}




\begin{tabular}{|c|c|c|c|c|c|c|c|c|c|c|c|c|c|c|}
\hline $\mathrm{Ta}$ & 0.24 & 0.17 & 0.32 & 0.32 & 0.29 & 0.25 & 0.15 & 0.14 & 0.24 & 0.15 & 0.24 & 0.48 & 0.07 & 1.8 \\
\hline $\mathrm{Hf}$ & 2.1 & 1.7 & 2.1 & 1.8 & 1.8 & 1.7 & 1.4 & 1.1 & 1.4 & 1.2 & 1.7 & 2 & 0.9 & 14.6 \\
\hline $\mathrm{Nb}$ & 3.5 & 2.5 & 3.7 & 3.3 & 3 & 2.7 & 2.3 & 1.8 & 2.3 & 1.9 & 2.9 & 3.5 & 1.5 & 23.3 \\
\hline $\mathrm{Y}$ & 26 & 21.5 & 22.6 & 21.5 & 26.6 & 21.1 & 19.1 & 19 & 17.7 & 16.5 & 21.7 & 28.1 & 13.1 & 67.2 \\
\hline Th & 0.31 & 0.26 & 1.12 & 0.65 & 0.39 & 0.32 & 0.29 & 0.19 & 0.21 & 0.25 & 0.27 & 0.34 & 0.16 & 21.5 \\
\hline $\mathrm{U}$ & 0.12 & 0.11 & 0.25 & 0.16 & 0.12 & 0.1 & 0.07 & 0.05 & 0.07 & 0.07 & 0.09 & 0.12 & 0.06 & 4.13 \\
\hline V & 394 & 315 & 319 & 213 & 313 & 357 & 357 & 309 & 321 & 244 & 351 & 337 & 408 & 28 \\
\hline $\mathrm{Co}$ & 54 & 42 & 41 & 43 & 43 & 46 & 54 & 48 & 48 & 37 & 40 & 42 & 48 & 7 \\
\hline $\mathrm{Cr}$ & 330 & 30 & 240 & 320 & 160 & 30 & 30 & 20 & 30 & 580 & 240 & 200 & 330 & $<20$ \\
\hline $\mathrm{Ni}$ & 130 & 90 & 140 & 190 & 130 & 80 & 100 & 80 & 90 & 130 & 120 & 110 & 140 & $<20$ \\
\hline $\mathrm{La}$ & 3.52 & 4.96 & 8.23 & 5.82 & 5.44 & 4.57 & 3.99 & 4.62 & 3.05 & 2.96 & 5.78 & 5 & 3.32 & 111 \\
\hline $\mathrm{Ce}$ & 8.09 & 12.3 & 18.4 & 13.6 & 13.4 & 11 & 10.1 & 8.96 & 8.58 & 7.76 & 12.9 & 12.4 & 5.92 & 215 \\
\hline $\mathrm{Nd}$ & 8.36 & 9.66 & 10.9 & 9.22 & 10.6 & 8.07 & 7.54 & 9.34 & 6.38 & 6.15 & 9.04 & 10.1 & 5.29 & 82.9 \\
\hline $\mathrm{Sm}$ & 2.93 & 3.11 & 3.02 & 2.8 & 3.63 & 2.64 & 2.43 & 2.79 & 2.08 & 1.86 & 2.8 & 3.3 & 1.62 & 15.4 \\
\hline $\mathrm{Eu}$ & 1.57 & 1.11 & 1.06 & 1.02 & 1.25 & 1.01 & 1.06 & 1.11 & 0.848 & 0.825 & 1.31 & 1.34 & 0.763 & 2.71 \\
\hline $\mathrm{Gd}$ & 4.05 & 3.69 & 3.64 & 3.36 & 4.41 & 3.62 & 3.02 & 3.33 & 2.87 & 2.61 & 3.47 & 4.44 & 2.11 & 13.1 \\
\hline $\mathrm{Tb}$ & 0.71 & 0.68 & 0.65 & 0.62 & 0.84 & 0.62 & 0.54 & 0.58 & 0.52 & 0.47 & 0.62 & 0.77 & 0.38 & 2.02 \\
\hline Dy & 4.52 & 4.14 & 3.95 & 3.85 & 5.41 & 3.86 & 3.43 & 3.66 & 3.22 & 2.86 & 3.86 & 4.78 & 2.32 & 11.9 \\
\hline Ho & 0.91 & 0.82 & 0.79 & 0.78 & 1.06 & 0.75 & 0.71 & 0.72 & 0.64 & 0.54 & 0.76 & 0.97 & 0.48 & 2.31 \\
\hline $\mathrm{Er}$ & 2.53 & 2.28 & 2.22 & 2.19 & 3.12 & 2.16 & 1.97 & 2.04 & 1.8 & 1.56 & 2.12 & 2.68 & 1.4 & 6.82 \\
\hline $\mathrm{Tm}$ & 0.358 & 0.329 & 0.314 & 0.32 & 0.491 & 0.327 & 0.273 & 0.303 & 0.263 & 0.221 & 0.315 & 0.377 & 0.197 & 0.98 \\
\hline $\mathrm{Yb}$ & 2.38 & 2.22 & 2.09 & 2.1 & 3.26 & 2.08 & 1.76 & 2.03 & 1.72 & 1.41 & 2.02 & 2.47 & 1.3 & 6.43 \\
\hline $\mathrm{Lu}$ & 0.365 & 0.343 & 0.322 & 0.31 & 0.498 & 0.317 & 0.288 & 0.305 & 0.264 & 0.221 & 0.308 & 0.383 & 0.196 & 0.997 \\
\hline $\mathrm{Cu}$ & 10 & 80 & 100 & 100 & 150 & 200 & 130 & 160 & 150 & 120 & 150 & 150 & 140 & $50 \mathrm{~F}$ \\
\hline $\mathrm{Zn}$ & 180 & 70 & 130 & 80 & 80 & 70 & 110 & 80 & 80 & 70 & 120 & 80 & 70 & $70 \mathrm{~V}$ \\
\hline
\end{tabular}




\begin{tabular}{|c|c|c|c|c|c|c|c|c|c|c|c|c|c|c|}
\hline As & $<5$ & $<5$ & $<5$ & $<5$ & $<5$ & $<5$ & $<5$ & $<5$ & $<5$ & $<5$ & $<5$ & $<5$ & $<5$ & $<5$ \\
\hline $\operatorname{Pr}$ & 1.59 & 2.07 & 2.47 & 2 & 2.32 & 1.74 & 1.62 & 1.98 & 1.31 & 1.23 & 1.85 & 2.12 & 1.14 & 23.5 \\
\hline Mo & $<2$ & $<2$ & $<2$ & $<2$ & $<2$ & $<2$ & $<2$ & $<2$ & $<2$ & $<2$ & $<2$ & $<2$ & $<2$ & $<2$ \\
\hline $\mathrm{Pb}$ & $<5$ & $<5$ & $<5$ & $<5$ & $<5$ & $<5$ & $<5$ & $<5$ & $<5$ & $<5$ & 6 & 7 & $<5$ & 7 \\
\hline W & 0.5 & 5 & 3.1 & 5.5 & 4.8 & 3.9 & 1.7 & 2.9 & 5.4 & 2.9 & 2.8 & 3.9 & 3.6 & 3.1 \\
\hline
\end{tabular}

Table 3. 3. Sm/Nd analytical results for metabasites from the Fazenda Velha Metabasic Suite of the Itaiacoca Group and metarhyodacite of Bairro dos Prestes Formation.

\begin{tabular}{cccccccccccc}
\hline Sample & $\mathrm{Sm}(\mathrm{ppm})$ & $\mathrm{Nd}(\mathrm{ppm})$ & ${ }^{147} \mathrm{Sm} /{ }^{144} \mathrm{Nd}$ & Error & ${ }^{143} \mathrm{Nd} /{ }^{144} \mathrm{Nd}$ & Error & $\mathrm{f}_{\mathrm{Sm} / \mathrm{Nd}}$ & $\varepsilon_{\mathrm{Nd}(0)}$ & $\mathrm{T}_{\mathrm{DM}}(\mathrm{Ma})$ & $\varepsilon_{\mathrm{Nd}(\mathrm{t})}$ & $\mathrm{Sm} / \mathrm{Nd}$ \\
\hline CA1 & 2.689 & 8.255 & 0.1970 & 0.0012 & 0.512790 & 0.000004 & 0.00 & 2.97 & 2312.89 & 2.9 & 0.326 \\
$\mathrm{CA} 8$ & 2.800 & 9.174 & 0.1846 & 0.0011 & 0.512728 & 0.000006 & -0.06 & 1.75 & 1630.42 & 2.7 & 0.305 \\
$\mathrm{CA62}$ & 2.662 & 8.773 & 0.1835 & 0.0011 & 0.512737 & 0.000006 & -0.07 & 1.92 & 1527.83 & 2.9 & 0.303 \\
$\mathrm{CA66}$ & 2.686 & 8.899 & 0.1825 & 0.0011 & 0.512712 & 0.000006 & -0.07 & 1.44 & 1599.15 & 2.5 & 0.302 \\
$\mathrm{CA67}$ & 3.515 & 11.274 & 0.1885 & 0.0011 & 0.512721 & 0.000004 & -0.04 & 1.63 & 1928.75 & 2.2 & 0.312 \\
$\mathrm{CA130}$ & 2.315 & 7.550 & 0.1854 & 0.0011 & 0.512760 & 0.000004 & -0.06 & 2.38 & 1506.28 & 3.2 & 0.307 \\
$\mathrm{CA131}$ & 2.316 & 7.717 & 0.1815 & 0.0011 & 0.512717 & 0.000004 & -0.08 & 1.54 & 1525.13 & 2.7 & 0.300 \\
$\mathrm{CA132}$ & 2.858 & 9.877 & 0.1749 & 0.0010 & 0.512710 & 0.000012 & -0.11 & 1.41 & 1300.60 & 3.1 & 0.289 \\
$\mathrm{CA133}$ & 1.745 & 5.476 & 0.1927 & 0.0011 & 0.512788 & 0.000004 & -0.02 & 2.93 & 1824.38 & 3.2 & 0.319 \\
$\mathrm{CA134}$ & 1.778 & 5.743 & 0.1872 & 0.0011 & 0.512752 & 0.000004 & -0.05 & 2.22 & 1652.52 & 3.0 & 0.309 \\
F134 & 2.566 & 8.914 & 0.1741 & 0.0010 & 0.512697 & 0.000004 & -0.12 & 1.16 & 1321.27 & 2.9 & 0.288 \\
F135 & 3.136 & 10.360 & 0.1830 & 0.0011 & 0.512726 & 0.000004 & -0.07 & 1.73 & 1555.62 & 2.8 & 0.303 \\
P13 & 1.260 & 4.012 & 0.1898 & 0.0011 & 0.512739 & 0.000004 & -0.03 & 1.97 & 1924.49 & 2.5 & 0.314 \\
CA39 & 16.118 & 94.665 & 0.1030 & 0.0006 & 0.511210 & 0.000003 & -0.48 & -27.86 & 2537.92 & -6.8 & 0.170
\end{tabular}

$\varepsilon_{\mathrm{Nd}(t)}$ determinated with the age calculated by U-Pb in zircon (600 and $1761 \mathrm{Ma}$, this paper). $\mathrm{T}_{\mathrm{DM}}$ calculated with the depleted mantle model of DePaolo (1981). 
High resolution Ion Microprobe (SHRIMP IIe) U-Pb isotopic analysis were performed at the University of São Paulo, using a spot size $\sim 25 \mu \mathrm{m}$. The ${ }^{206} \mathrm{~Pb} /{ }^{238} \mathrm{U}$ ratios were calibrated with the Temora 2 standard (concordant $416.78 \mathrm{Ma}$; Black et al., 2004), and for the common ${ }^{206} \mathrm{~Pb}$ correction was using the Stacey and Kramers (1975) procedure based on ${ }^{204} \mathrm{~Pb}$ measured. The graphic representation and the age calculation was generated with ISOPLOT 4 program (Ludwing, 2009).

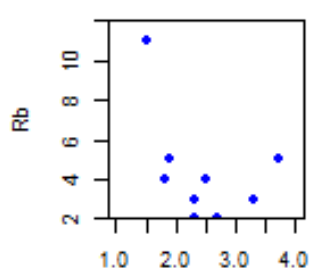

$\mathrm{Nb}$

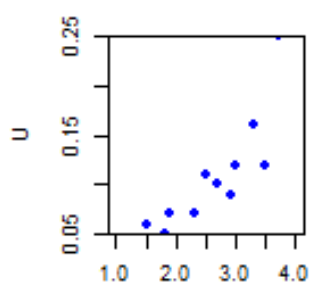

$\mathrm{Nb}$

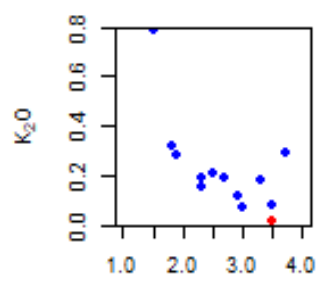

$\mathrm{Nb}$

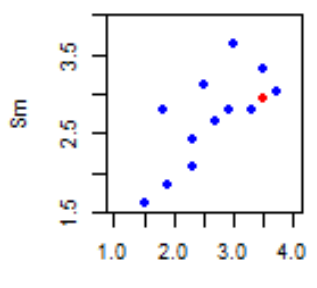

$\mathrm{Nb}$

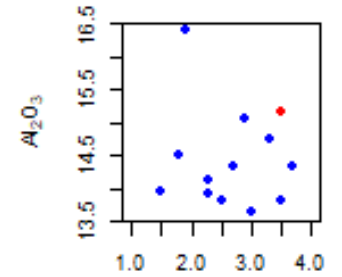

$\mathrm{Nb}$

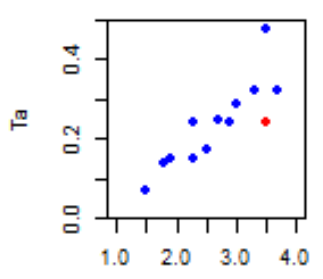

$\mathrm{Nb}$

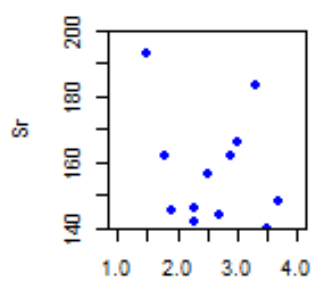

$\mathrm{Nb}$

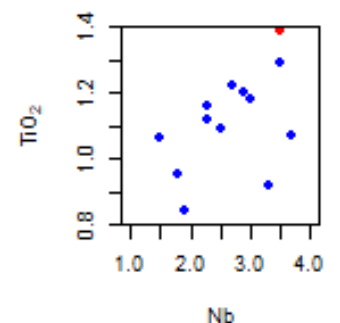

$\mathrm{Nb}$

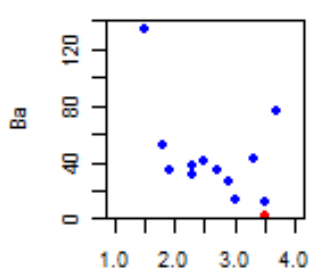

$\mathrm{Nb}$

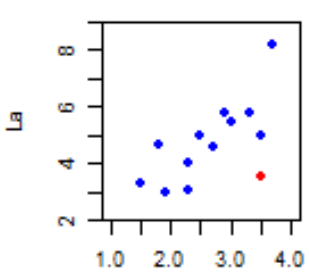

$\mathrm{Nb}$

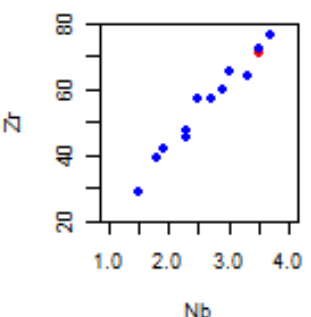

$\mathrm{Nb}$

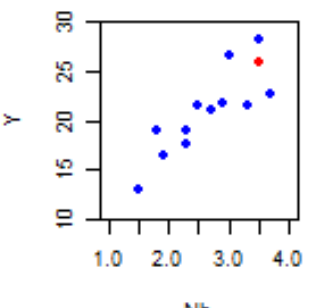

$\mathrm{Nb}$

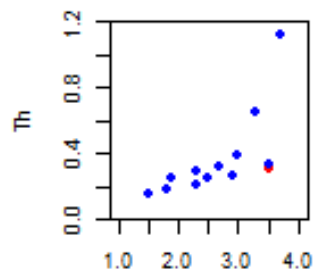

$\mathrm{Nb}$

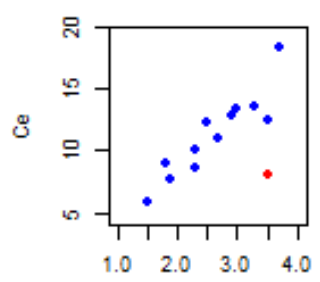

$\mathrm{Nb}$

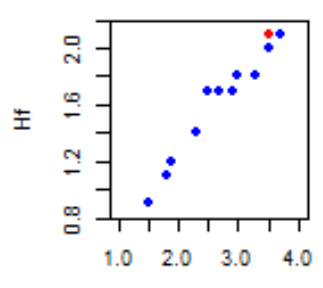

$\mathrm{Nb}$

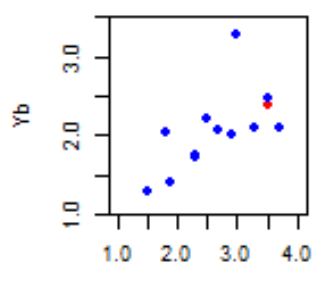

$\mathrm{Nb}$

Figure 3. 6. Binary plots of $\mathrm{Nb}$ vs. $\mathrm{Rb}, \mathrm{U}, \mathrm{K} 2 \mathrm{O}, \mathrm{Sm}, \mathrm{Al} 2 \mathrm{O} 3$, $\mathrm{Ta}, \mathrm{Sr}, \mathrm{TiO} 2, \mathrm{Ba}, \mathrm{La}, \mathrm{Zr}, \mathrm{Y}, \mathrm{Th}, \mathrm{Ce}, \mathrm{Hf}$ and $\mathrm{Yb}$ from metabasites. In red, the CA1 sample.

\subsection{RESULTS}

\subsubsection{Element mobility}

The mineral assemblage composed of actinolite, chlorite and epidote suggests that the metabasic rocks were affected by a greenschists facies metamorphism. The presence of carbonate, quartz and epidote veins in some samples is evidence of superimposed hydrothermal 
events, which could have favored the formation and mobilization of ionic complexes (Rollinson, 1993; Pearce, 1996). For this reason, it is necessary to test the elements mobility, that may be estimate through diagrams of molecular ratios (Pearce, 1968; Beswick and Soucie, 1978 and Beswick, 1982) and binary plots (Cann, 1970).

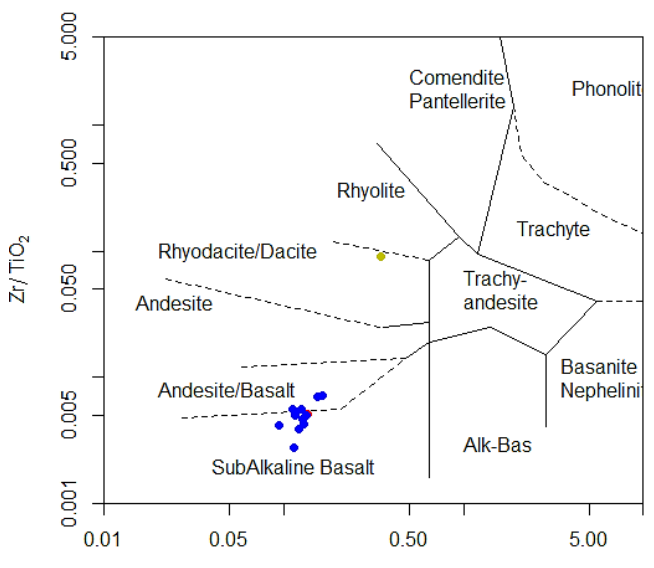

(a)

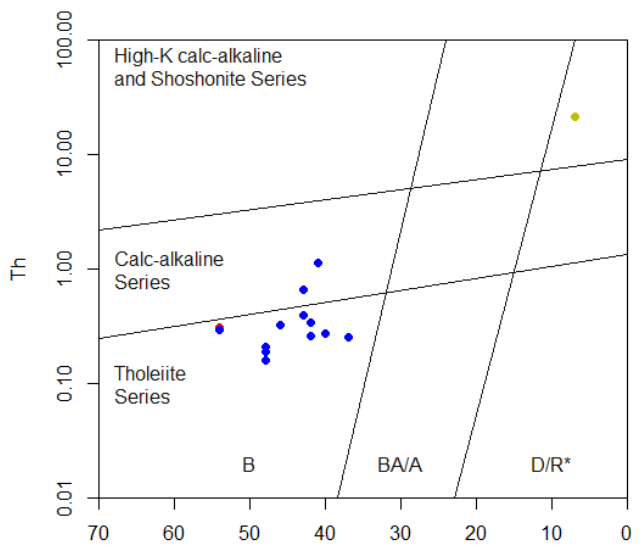

(c) (b)

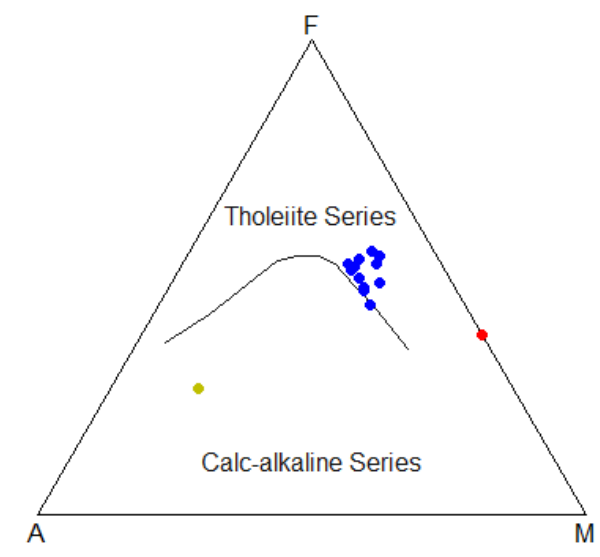

(d)

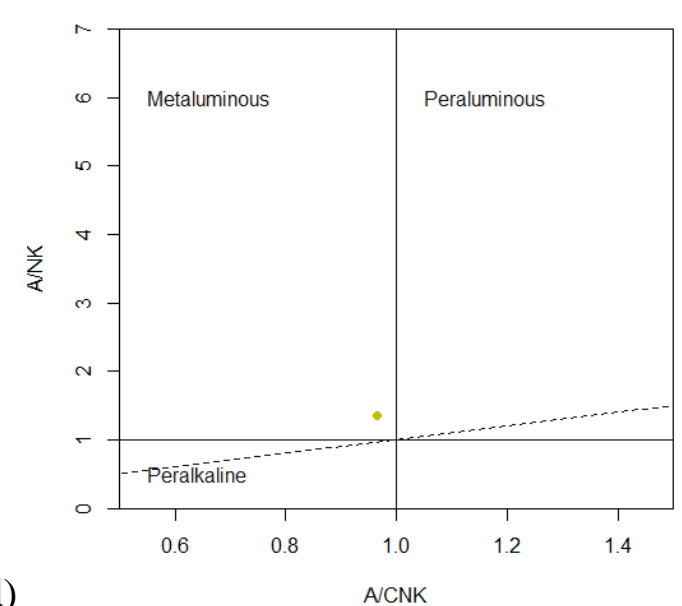

A/CNK

Figure 3. 7. Diagrams for the classification of metabasites from the Fazenda Velha Metabasic Suite of the Itaiacoca Group and metarhyodacite of Bairro dos Prestes Formation. (a) Nb/Y-Zr/TiO2 plot (Winchester and Floyd, 1977), (b) AFM plot (Irvine and Barragar, 1971), (c) Co-Th plot (Hastie et al., 2007) and (d) A/CNK-A/NK diagram (Shand, 1943). In red and yellow, the CA1 and CA39 sample, respectively.

The dispersion of points and their tendency through the origin on the molecular ratios diagrams (Figure 3.5) as the no linear correlation in the binary plots (Figure 3.6), reflect the mobility of the oxides and some large-ion lithophile elements (LILE) (e.g., Rb and Sr) in the samples during the metamorphism and hydrothermal events. While the linear trend of Th, U, REE and HFSE elements on binary diagram, indicates that these elements are immobiles and the original chemicals characteristics of protolith are mostly preserved. Sample CA1 was disregarded from interpretations because of petrographic and chemical evidence of strong metasomatism. 


\subsubsection{Whole rock geochemistry}

For the classification (rock type and volcanic series) of metabasites samples we compared the classical diagrams $\left(\mathrm{Nb} / \mathrm{Y}-\mathrm{Zr} / \mathrm{TiO}_{2}\right.$ and $\mathrm{AFM}$ plots; the TAS diagram is not use since the oxides correspond to the most mobile elements in the samples) with diagrams that employ immobile elements as the Co-Th plot of Hastie et al. (2007), created for the classification of altered, weathered and metamorphosed volcanic rocks. The metabasites exhibited tholeiitic and calcalkaline signatures (Figure 3.7b-c), classified as basalt and basaltic andesite (Figure 3.7a).

The REE concentrations of the metabasites are 10 to 12 times as chondrite values, with weak depletion to moderate enrichment of the LREE with respect to HREE (Figure 3.8a), as indicated in the $(\mathrm{La} / \mathrm{Yb}) \mathrm{cn}$ values from 0.9 to 1.9. The depletion of HREE together with the negative anomaly of $\mathrm{Zr}$ indicate that the garnet is responsible for the chemical response of these elements (Hanchar and Westrenen, 2007), implying the presence of this mineral as residual phase in the source (Haskins and Paster, 1984; Wilson, 2007; Jayananda 2013). Most samples present weak negative anomalies of $\mathrm{Ce}$ and positive anomalies de $\mathrm{Eu}$, which can be related with weak metasomatic effects caused by hydrothermal solutions and crystallization of abundant epidote (Dudás et al., 1983 in Shikazono, 2003). These oxidized hydrothermal fluids are responsible for the solubility of $\mathrm{Ce}^{4+}$ and its incorporation in the oxides and hydroxides of $\mathrm{Mn}$ (Courtois and Clauer, 1980; Mahoney et al., 2008), while the Eu was probably absorbed by the rocks through interactions with hydrothermal solutions.

In the MORB-normalized diagram (Figure 3.8b), the metabasites exhibit weak to strong enrichment in LILE and weak to moderate depletion in high field strength elements (HFSE), with $(\mathrm{Nb} / \mathrm{Yb}) \mathrm{mn}$ of $1.2-2.3$ and $(\mathrm{Th} / \mathrm{Yb}) \mathrm{mn}$ ratios of $2.3-7.8$ and $\mathrm{Nb} / \mathrm{Nb}^{*}$ values from $0.2-2.4$. The enrichment and anomalies of LILE can be modified due to the alterations and transformations that the rock suffered, the negative anomalies of $\mathrm{Ti}, \mathrm{Nb}, \mathrm{Zr}$ and $\mathrm{Hf}$ are controlled by the fractionation of minerals as titanite, rutile, ilmenite and sometimes amphiboles (Keshavarzi et al., 2014). Petrogenetic evidence, theoretical and experimental data indicate that $\mathrm{P}$ negative anomalies can be produced by a strong garnet fractionation or by partial melt of source with residual garnet, which is the mineral with higher concentration of $\mathrm{P}$ in the mantle (McCuaig, 1994). 

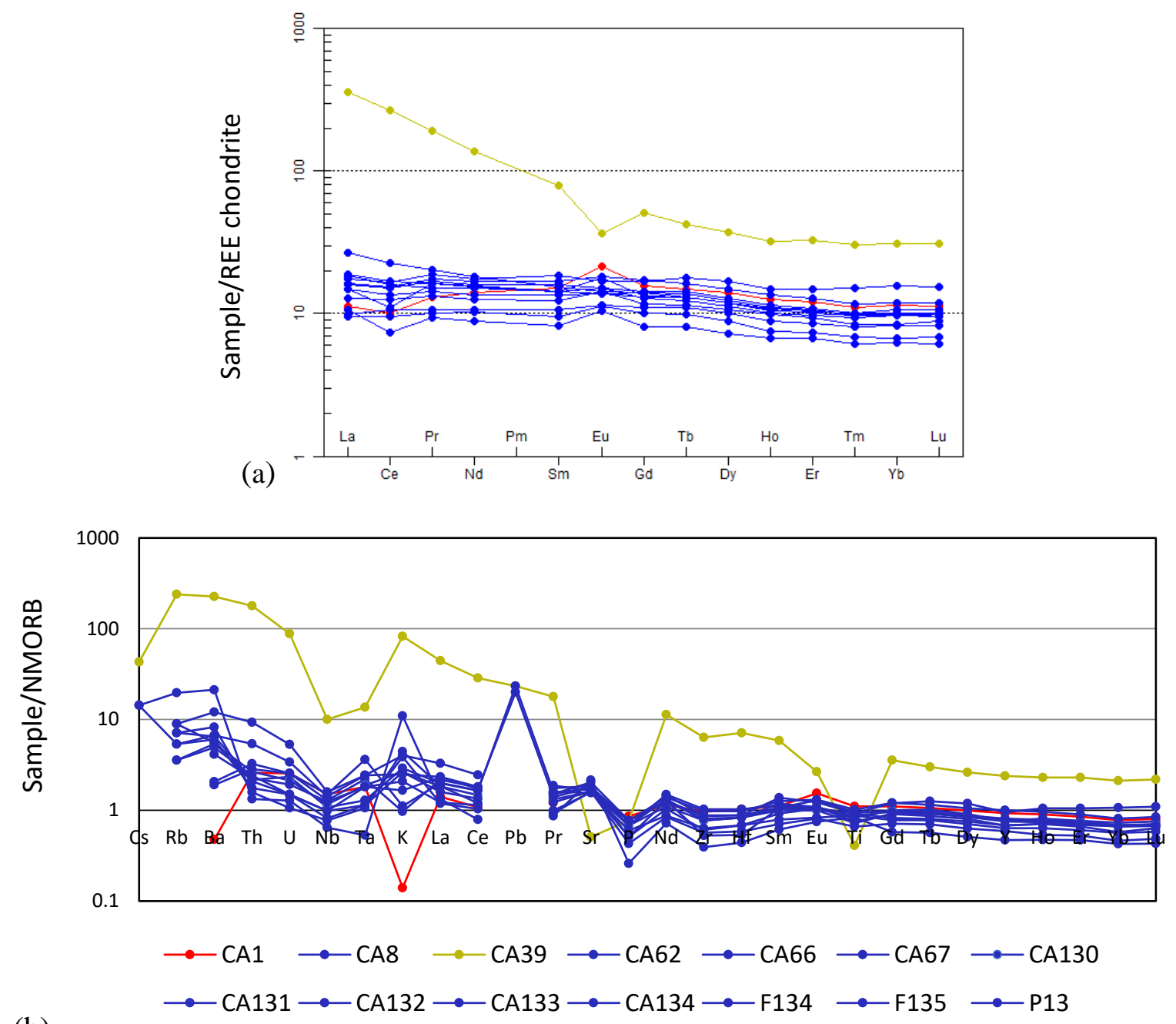

(b)

Figure 3. 8. (a) Rare earth element and (b) spidergrams from metabasites of Itaiacoca Group and metarhyodacite of Bairro dos Prestes Formation. Normalizing values with respect to Boynton (1984) for chondrite and Sun and McDonough (1989) for MORB

Sample CA39 of the Bairro dos Prestes Formation presents high-K calc-alkaline signatures (Figure 3.7b-c) and is classified as rhyodacite (Figure 3.7a). According to the alumina saturation (Figure 3.7d) the rock shows a metaluminous character. The REE concentration is 30-400 times more enriched than chondrite values (Figure 3.8a), with a strong enrichment of LREE relative to HREE with $(\mathrm{La} / \mathrm{Yb})_{\text {cn }}$ of 11.6. Sample CA39 presents negative Ti, P, Sr, Eu, Zr, Nb and Ta anomalies (Figure 3.7b). The negative $\mathrm{Eu}$ and $\mathrm{Sr}$ anomalies are attributed to the fractionation of feldspar during magma crystallization, while the negative $\mathrm{Ti}, \mathrm{Zr}$ and $\mathrm{P}$ anomalies probably indicate fractionation of iron-titanium oxide, zircon and apatite (Wilson, 2007; Keshavarzi et al., 2014). Enrichment of Ta relative to $\mathrm{Nb}$, and $\mathrm{Zr} / \mathrm{Hf}$ (32.3) and $\mathrm{Nb} / \mathrm{Ta}$ (12.9) ratios suggest that fractional crystallization, crustal melting and subduction zone magmatism could have controlled the origin of the metarhyodacite sample (Wilson, 2007; Green, 1995; Aliani et al., 2012; Dostal and Chatterjee, 2000). 


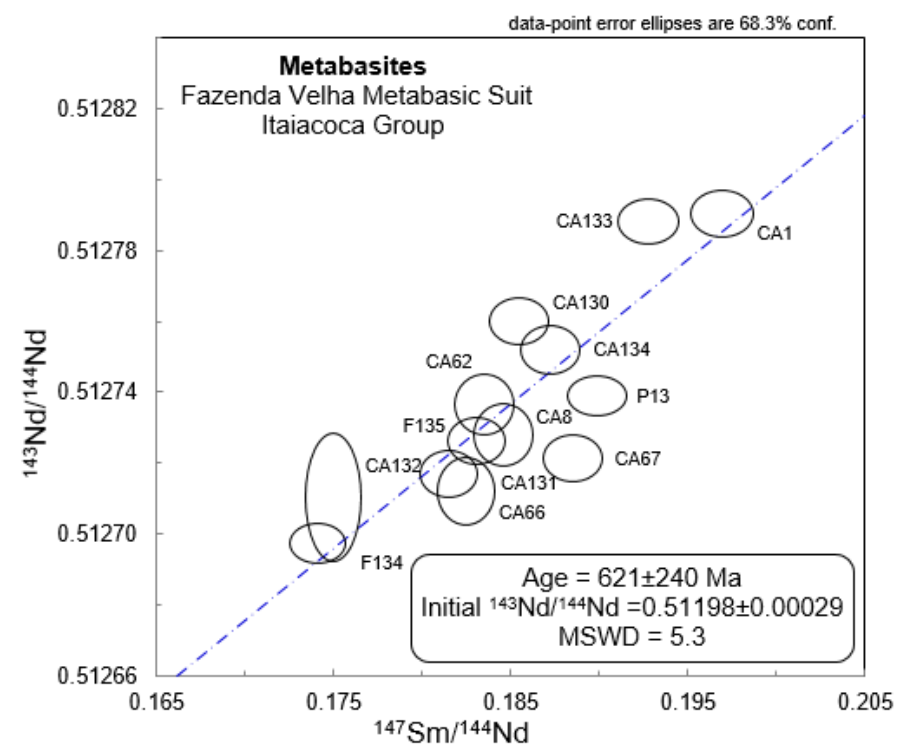

Figure 3. 9. Sm-Nd isochrone of the mebasites samples of the Fazenda Velha Metabasic Suite of the Itaiacoca Group.

\subsubsection{Sm-Nd radiogenic isotopes}

The metamafic rocks (Tables 3.2 and 3.3) present Sm and Nd content ranged from 1.2 to 3.6 ppm and 4.0 to $11.2 \mathrm{ppm}$, respectively. The isotopic rations ${ }^{147} \mathrm{Sm} /{ }^{144} \mathrm{Nd}$ vary between 0.1741 and 0.1927 , and ${ }^{143} \mathrm{Nd} /{ }^{144} \mathrm{Nd}$ between 0.512697 and 0.512788 . The $\varepsilon \mathrm{N}_{\mathrm{d}(0)}(+1.16-+2.97)$ and $\varepsilon \mathrm{N}_{\mathrm{d}(\mathrm{t})}(+2.2-+3.2)$ values implying that the basaltic magmas were derived from a common relative juvenile magma source. The calculated $\mathrm{T}_{\mathrm{DM}}$ model ages are between 1300 and 1928 Ma (average of $1608 \mathrm{Ma})$.

The metarhyodacite (Table 3.2 and 3.3) display Sm and Nd content of 15.4-16.1 and 82.4-94.6 ppm, respectively, the isotopic rations are: 0.10301 of ${ }^{147} \mathrm{Sm} /{ }^{144} \mathrm{Nd}$ and 0.511210 of ${ }^{143} \mathrm{Nd} /$ ${ }^{144} \mathrm{Nd}$. The negative $\varepsilon \mathrm{N}_{\mathrm{d}(0)}(-27.86)$ and $\varepsilon \mathrm{N}_{\mathrm{d}(\mathrm{t})}(-6.8)$ values implying older subcontinental mantle components, possibly of Archean age ( $\mathrm{T}_{\mathrm{DM}}$ model age calculated is $2537 \mathrm{Ma}$ ).

For the mebasites samples of the Fazenda Velha Metabasic Suite is also calculated Sm-Nd, isochrone with $621 \pm 240 \mathrm{Ma}$ and MSWD of 5.3 (Figure 3.9). 
F135 METABASITE
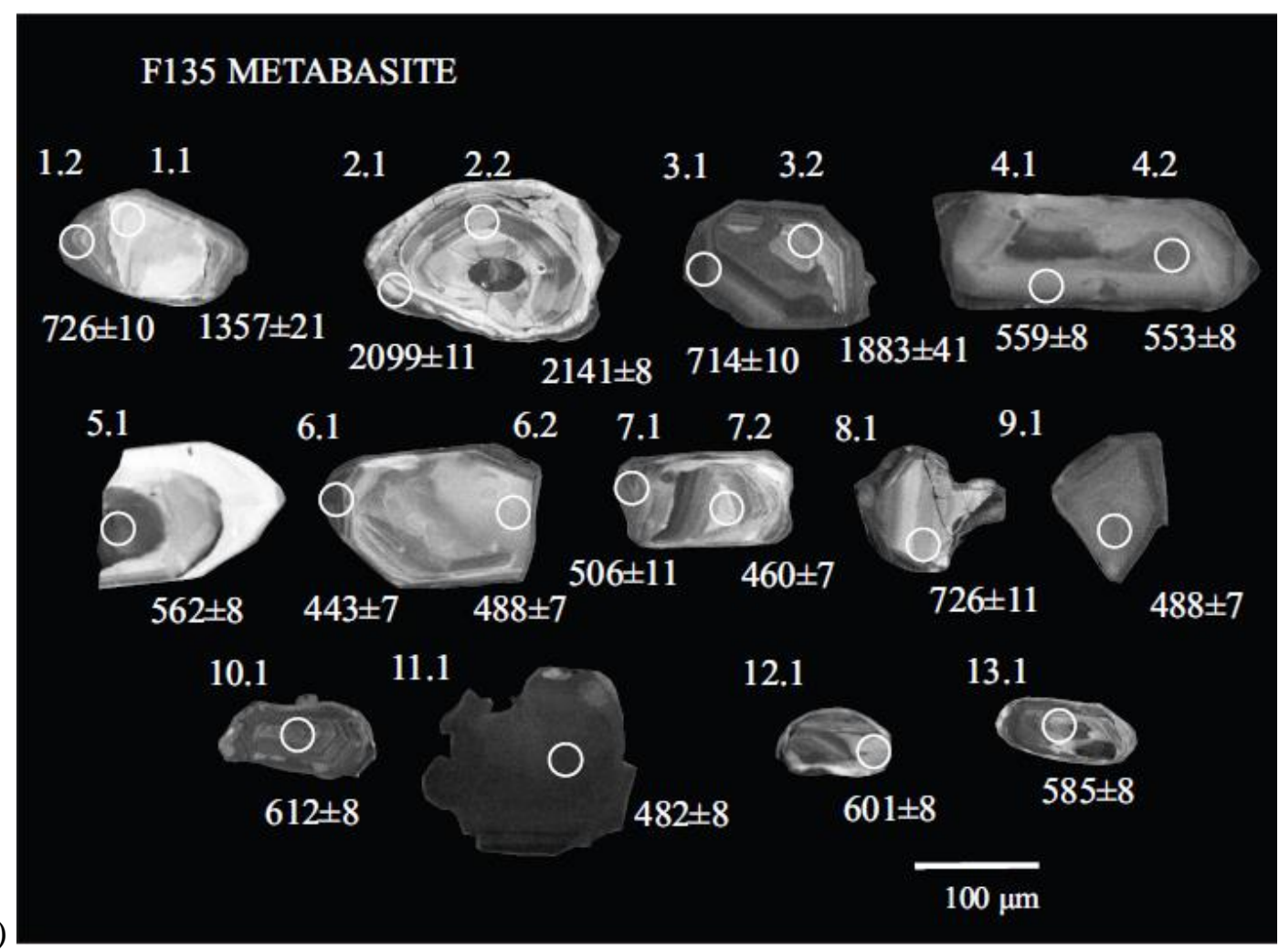

(a)

P13 METABASITE

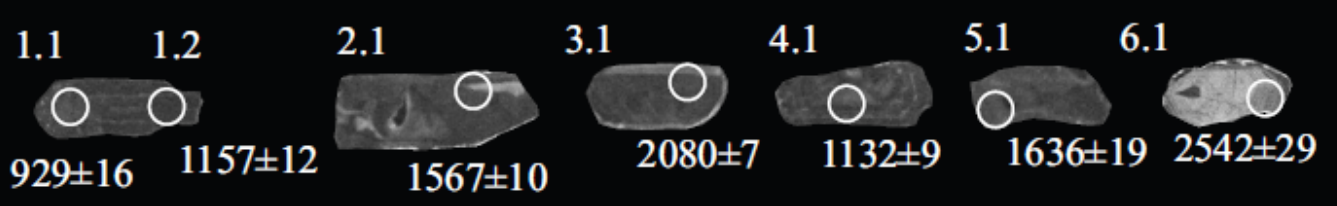

(b)
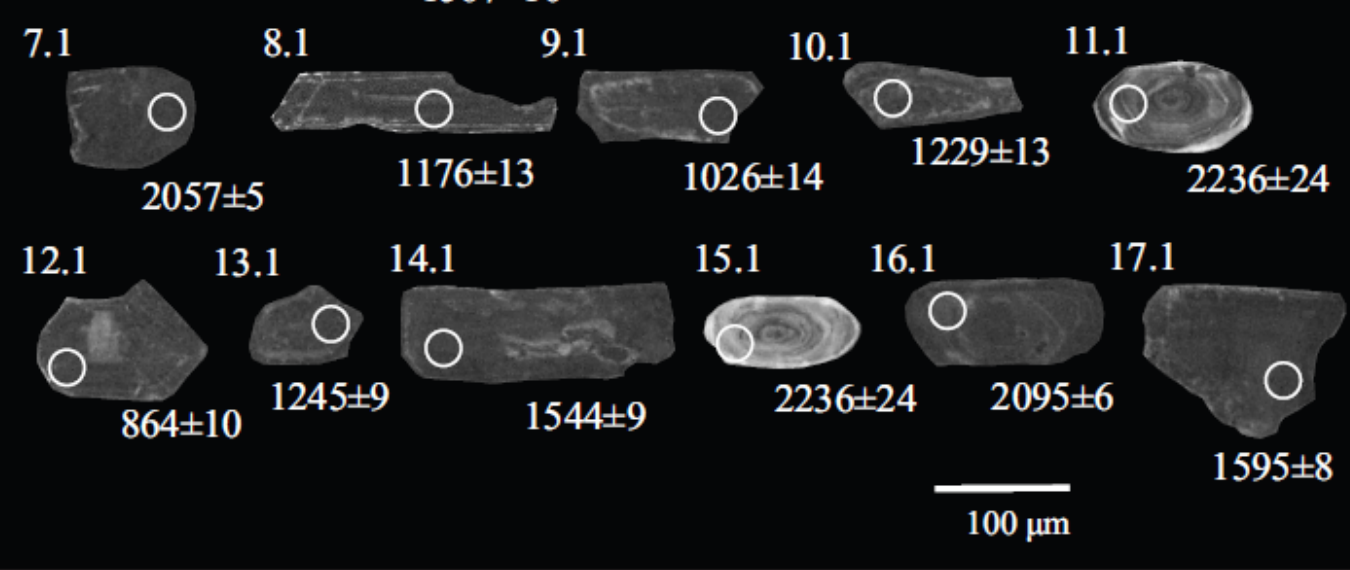
CA38 METAVOLCANOSEDIMENTARY
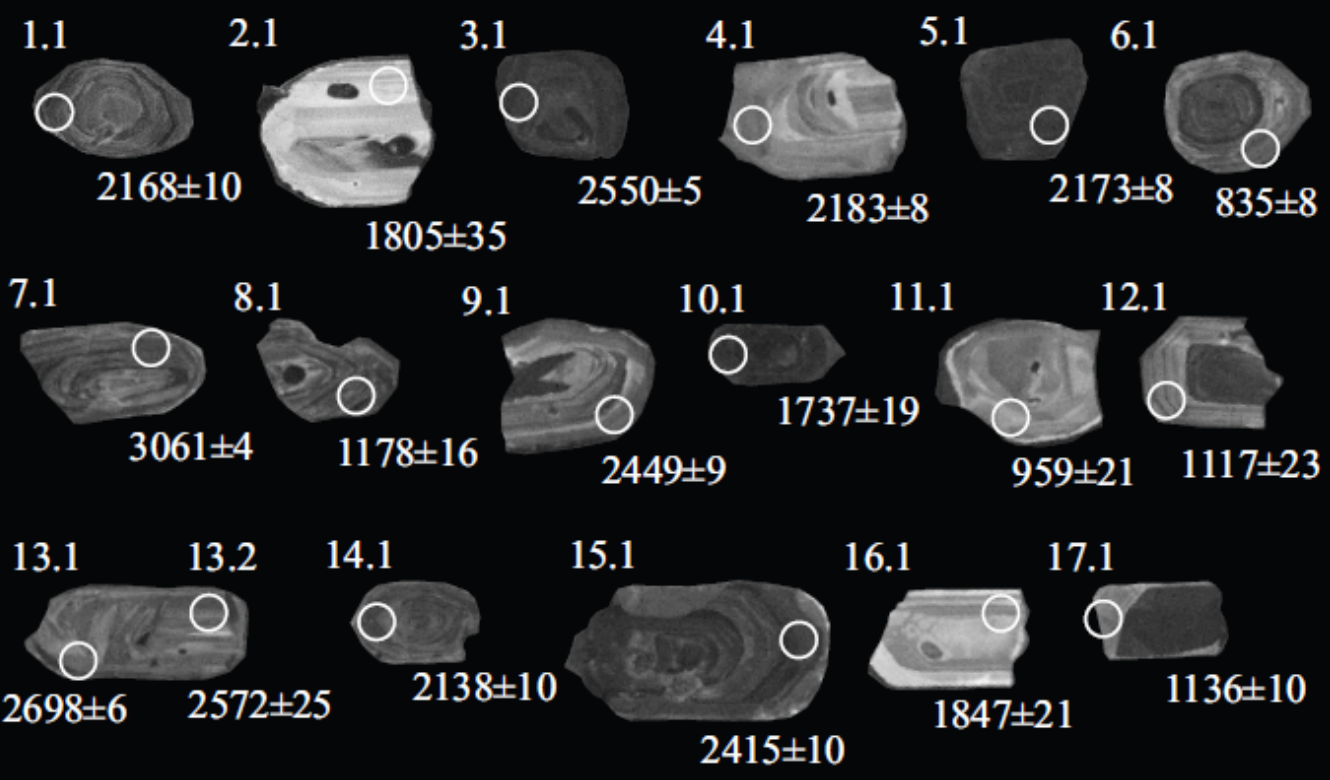

18.1

(c)

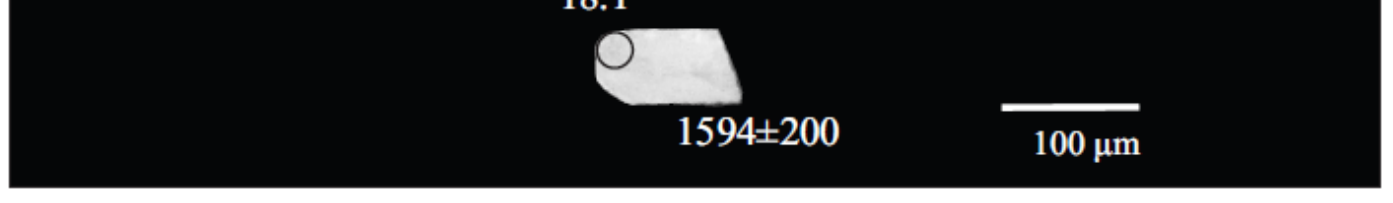

\section{CA39 METARHYODACITE}

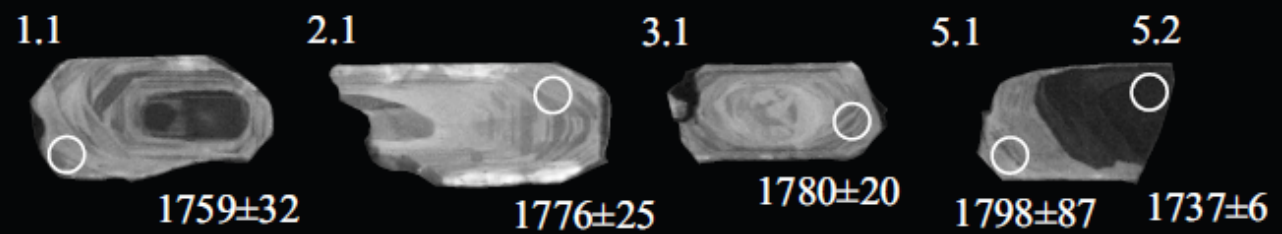

6.1

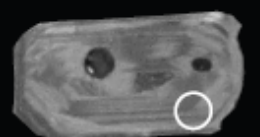
$1756 \pm 26$
7.1

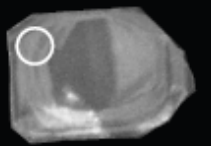

$1775 \pm 114$

10.1

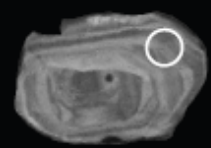

$1789 \pm 22$
8.1

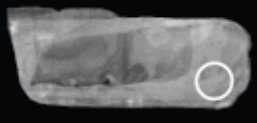

$1738 \pm 69$

11.1

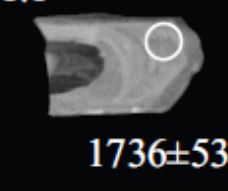

9.1

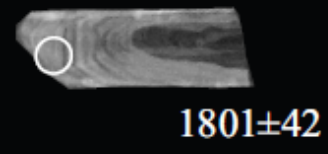

(d) 


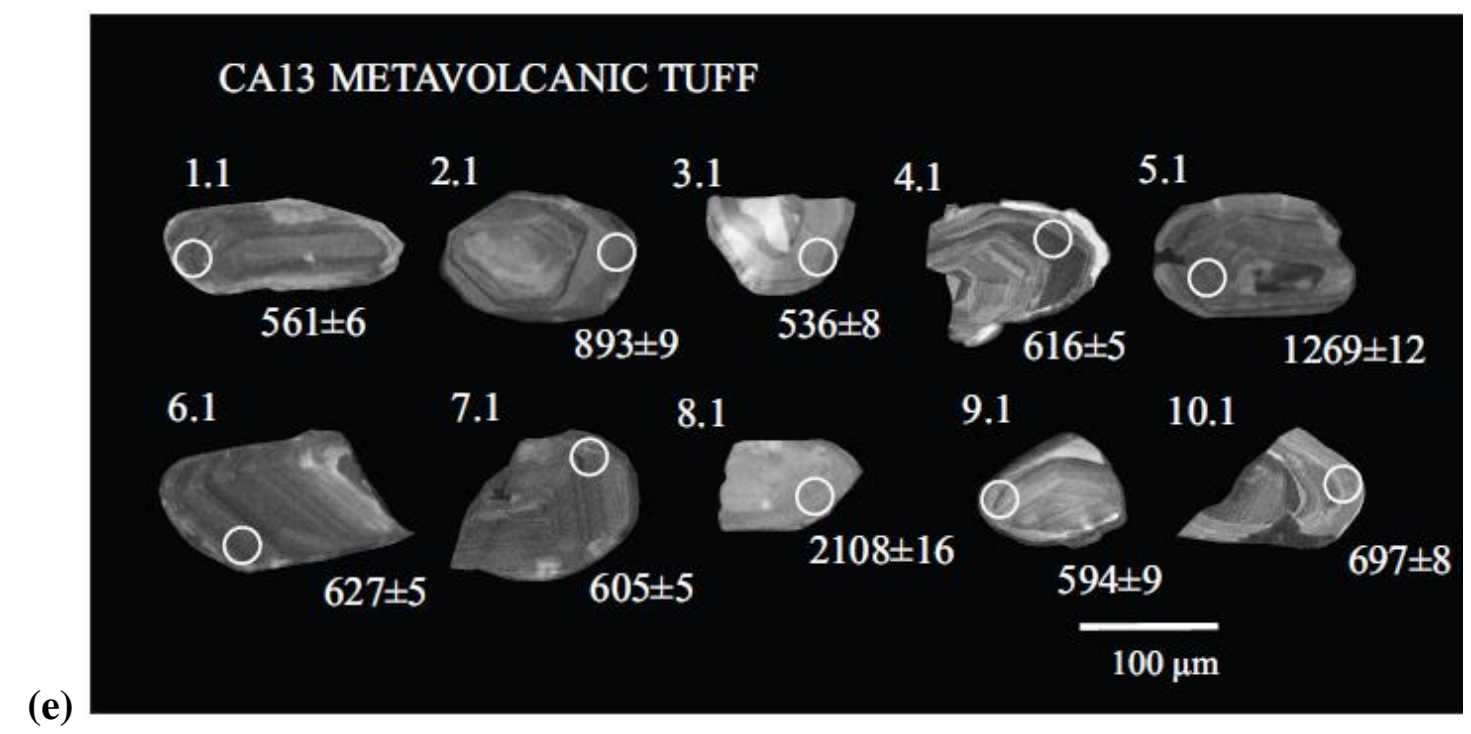

Figure 3. 10. CL images of zircon crystals from (a) metabasite - F135, (b) metabasite - P13 (c) metavolcanosedimentary- CA38, (d) metarhyodacite - CA39 and (e) metatuff-CA13 rock. In the pictures are indicated the spot analyses number and the ${ }^{206} \mathrm{~Pb} /{ }^{238} \mathrm{U}$ age for $<1300 \mathrm{Ma}$ and ${ }^{206} \mathrm{~Pb} /{ }^{207} \mathrm{~Pb}$ age for $>1300 \mathrm{Ma}$.

\subsubsection{U-Pb Geochronology data}

The U-Pb analyzes were made in five samples, including two metabasites from the Fazenda Velha Suite (F135 and P13), a metatuff from the Bairro dos Campos Formation (CA13) of the Itaiacoca Group, a metavolcanosedimentary rock (CA38) and metarhyodacite (CA39) of the Bairro dos Prestes Formation. The ages were calculated with SHRIMP data with less than $10 \%$ discordance $(<100 \pm 10 \%)$ and lower common $\mathrm{Pb}$ contents $(<5 \%)$. The metabasic samples (F135 and P13) are dark green metagabbros with coarse grained and reliquiar igneous textures (subophitic textures). Due to small amount of zircon crystals that crystallized in the metabasic rocks, $20 \mathrm{Kg}$ of each sample was collected and processed.

Anhedral to subhedral (subrounded) zircon grains were obtained from metabasite F135 sample, which can be divided in three subgroups classified according with the morphology and internal structure. The first subgroup appears dark and poorly zoned in CL images (4.1, 9.1, 10.1, 11.1, 12.1 and 13.1 zircons). The second subgroup includes clear crystals with weak zonation (5.1, 6.1, 7.1-7.2 and 8.1 grains), and the third subgroup presents crystals with partially absorbed nuclei and dark and poorly zoned overgrowth edges (1.1-1.2, 3.1-3.2 zircons. All SHRIMP U$\mathrm{Pb}$ spots analyses display low content of common $\mathrm{Pb}(<2 \%)$ and low $(>0.1$ and $<1.0) \mathrm{Th} / \mathrm{U}$ ratios. Thirteen $\mathrm{U}-\mathrm{Pb}$ spot analyses yield concordant apparent ages distributed in the intervals of 1880-2100, 1360, 710-730, 550-610 and 480-490 Ma (Figures 3.10a and 3.11a, Table $\mathrm{S}_{1}$ ). 
Five analyses of the most abundant age population yield a weighted average age of $571 \pm$ $25 \mathrm{Ma}$

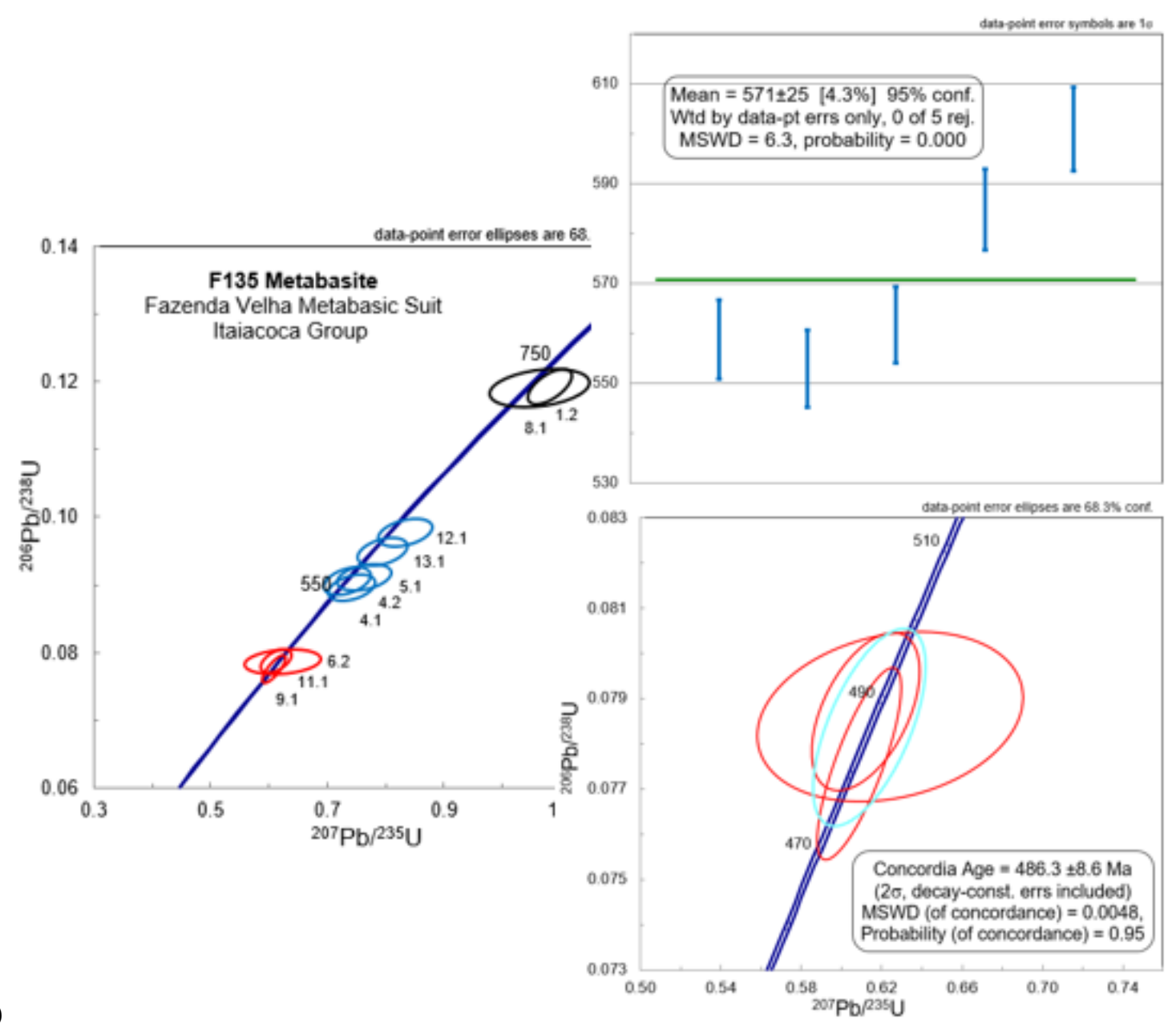


data-point error ellipses are $68.3 \%$ conf.

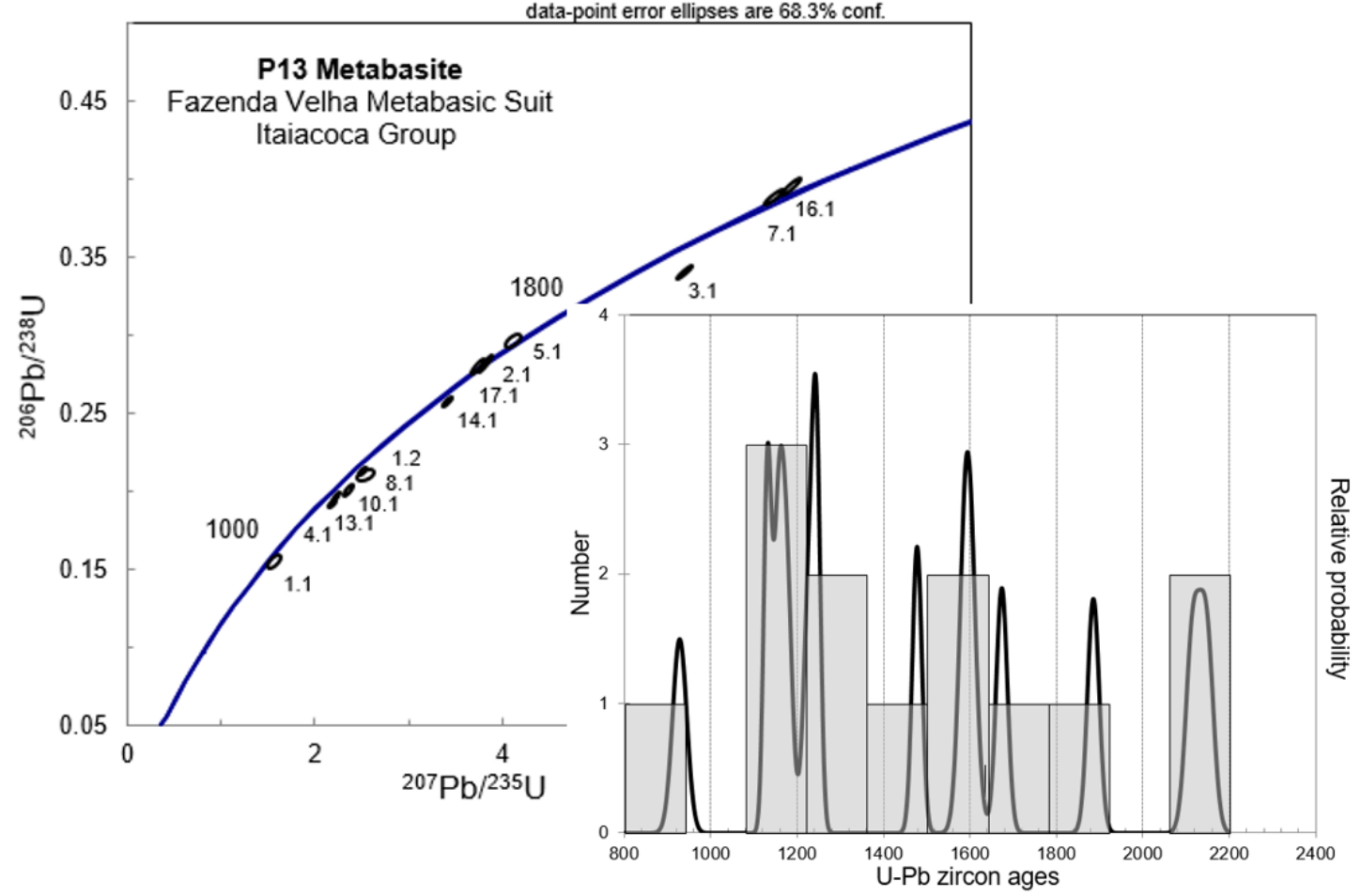

(b)

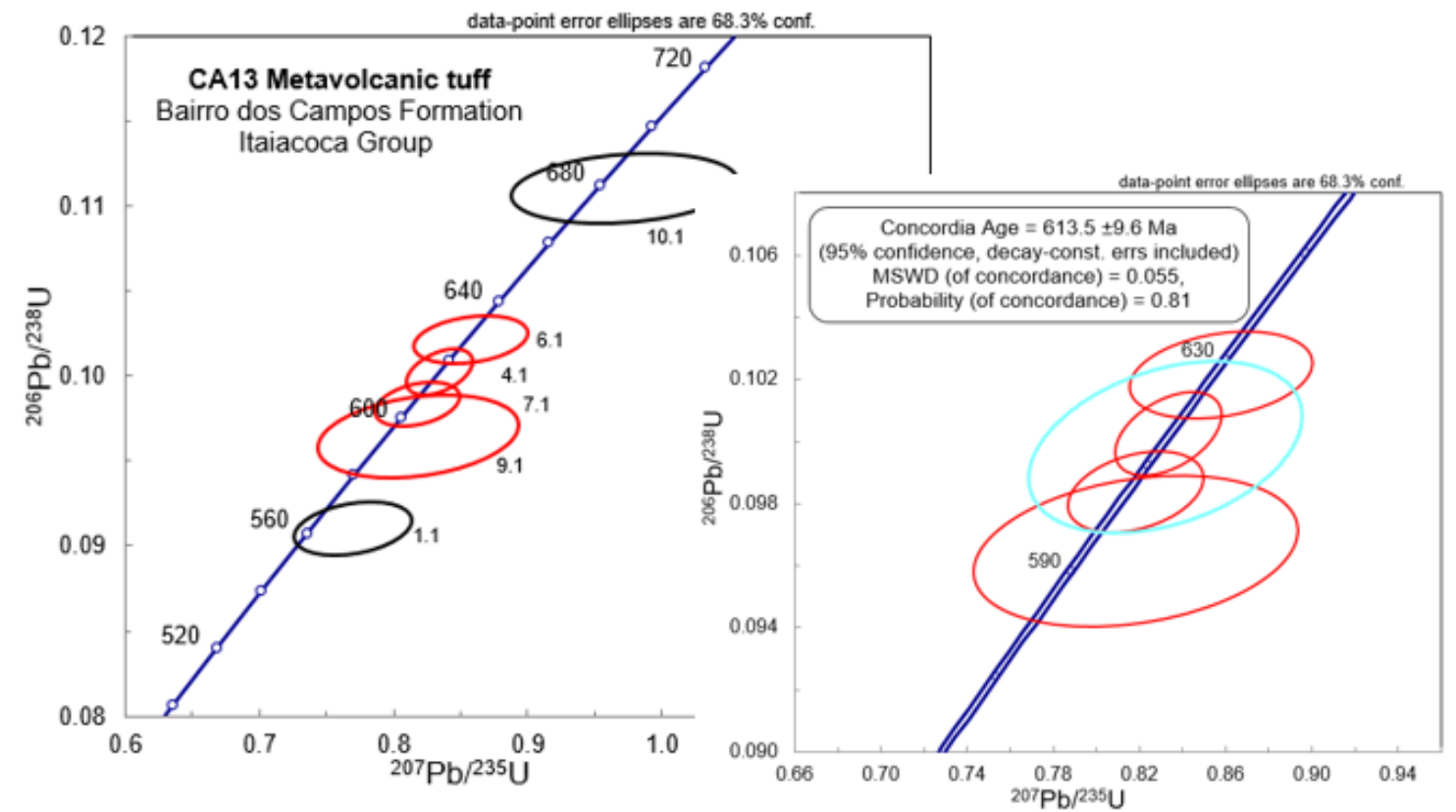




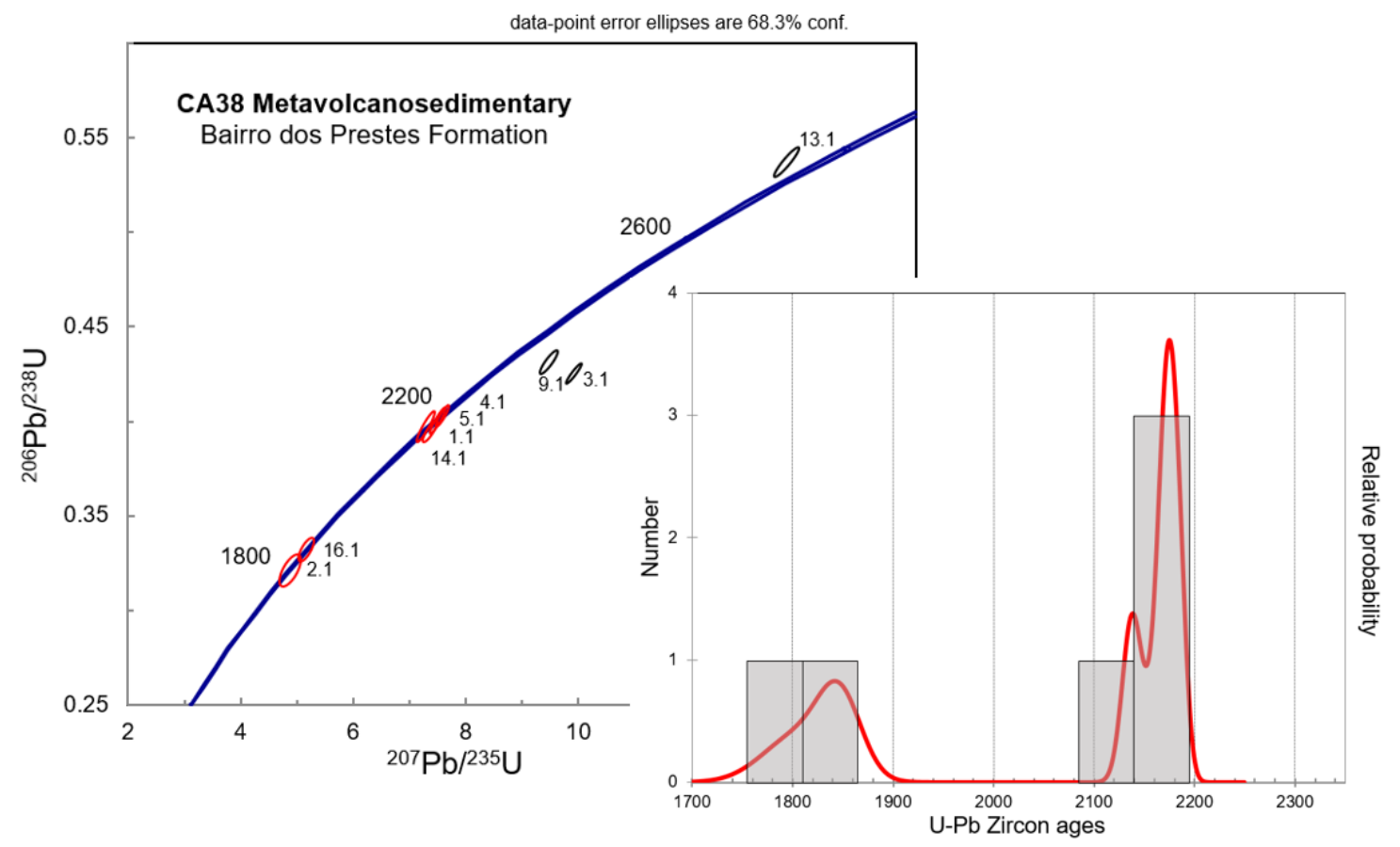

(d)

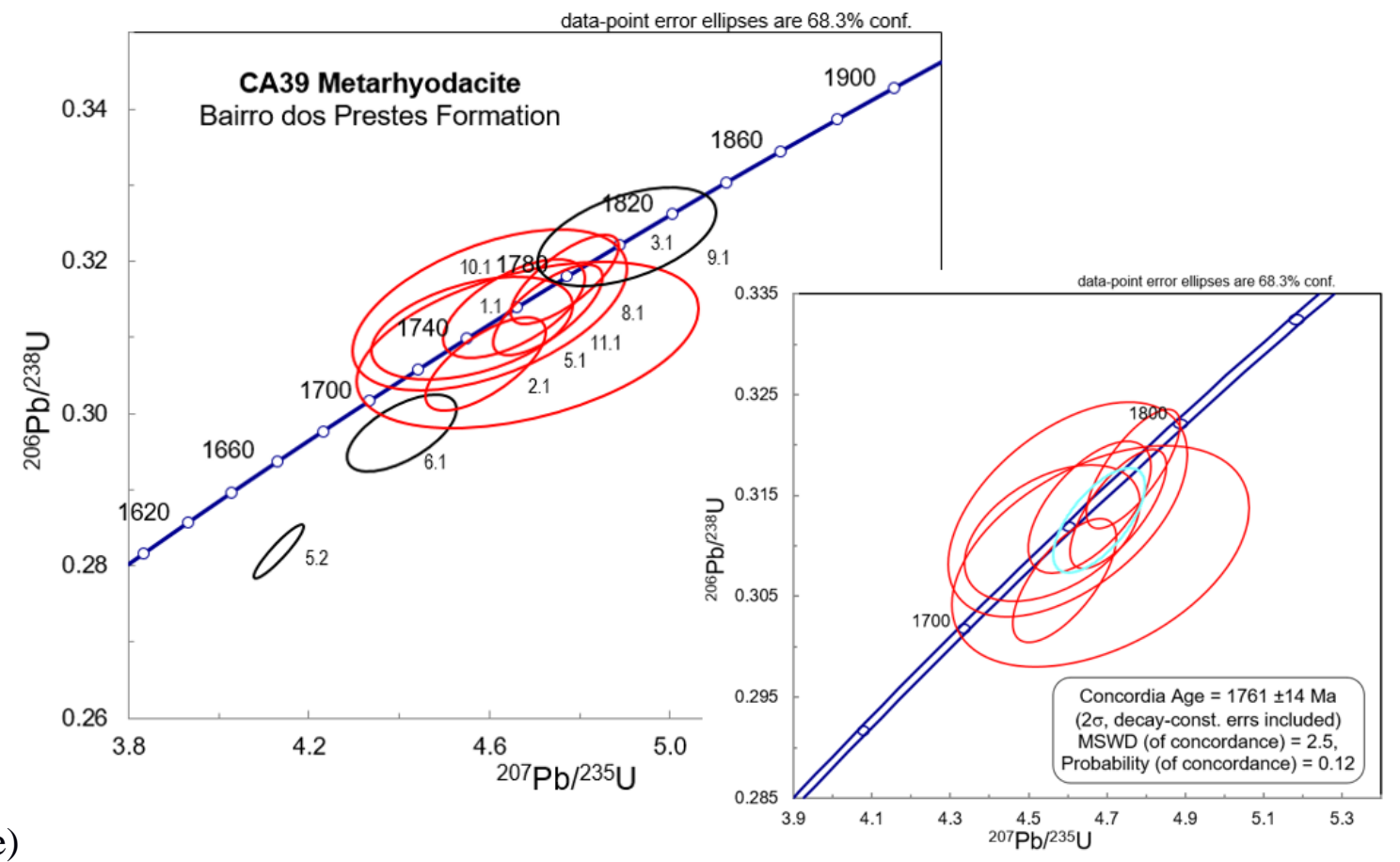

Figure 3. 11. Concordia diagram of: (a) ${ }^{207} \mathrm{~Pb} /{ }^{206} \mathrm{U}$ versus ${ }^{238} \mathrm{U} /{ }^{206} \mathrm{~Pb}$ of $\mathrm{F} 135$ sample with the concordia age and weighted average age for the first and second group, respectively (b) ${ }^{206} \mathrm{~Pb} /{ }^{238} \mathrm{U}$ versus ${ }^{207} \mathrm{~Pb} / 235 \mathrm{~Pb}$ of $\mathrm{P} 13$ metabasite with probability density plot of the data, (c) ${ }^{206} \mathrm{~Pb} /{ }^{238} \mathrm{U}$ versus ${ }^{207} \mathrm{~Pb} /{ }^{235} \mathrm{~Pb}$ of CA13 metatuff, (d) ${ }^{206} \mathrm{~Pb} /{ }^{238} \mathrm{U}$ versus ${ }^{207} \mathrm{~Pb} /{ }^{235} \mathrm{~Pb}$ of CA38 metavolcanosedimentary with probability density plot of the chosen spots and (e) ${ }^{207} \mathrm{~Pb} /{ }^{206} \mathrm{U}$ versus ${ }^{238} \mathrm{U} /{ }^{206} \mathrm{~Pb}$ of CA39 metarhyodacite rock.

$(\mathrm{MSWD}=0.0048)$ inferred as the best estimation for the igneous crystallization. Based on internal zircon textures and $\mathrm{U}-\mathrm{Pb}$ spot analyses the three oldest age populations are inferred as inherited zircon grains, while the youngest zircon population with Concordia age of $486 \pm 9$ $\mathrm{Ma}$ (Figure 3.11a) are interpreted as evidence of a late hydrothermal event. 
The metabasite P13 sample present zircons with anhedral habit generally round, with homogeneous dark zoning (2.1, 5.1, 6.1, 7.1, 9.1 and 10.1 grains), sometimes developing weak oscillatory zoning (1.1-1.2, 3.1, 4.1, 8.1 and 11.1 zircons). The SHRIMP analyses have low $(>0.1$ and $<1.0) \mathrm{Th} / \mathrm{U}$ ratios. Sixteen $\mathrm{U}-\mathrm{Pb}$ ages yield concordant ages with populations at 3300 , 2000-2200, 1500-1600 and 900-1300 Ma (Figures 3.10b and 3.11b, Table $\mathrm{S}_{2}$ ). A single grain (spot 1.1) give an age of $\sim 900 \mathrm{Ma}$, considered as the youngest detritical zircon obtained.

The zircon grains from CA13 metatuff sample are subhedral (subrounded), with equant to prismatic habit and oscillatory compositional zoning (Figure 3.10d), the zircons 2.1 and 9.1 present discontinuity in the original zoning, which are succeeded by newgrowth zoned, reflected intervals of $\mathrm{Zr}$ undersaturation conditions (Corfu, 2003). The SHRIMP analyses (Table $\mathrm{S}_{3}$ ), show low content of common $\mathrm{Pb}(<2 \%)$, and low $(>0.1$ and $<1.0) \mathrm{Th} / \mathrm{U}$ ratios. Eight $\mathrm{U}-\mathrm{Pb}$ analyses yield concordant apparent age within the main intervals of 2110, 1269 and 560$720 \mathrm{Ma}$ ((Figures 3.10d and 3.11c, Table $\mathrm{S}_{3}$ ). Four analyses of the main zircon population give a concordia age of $613.5 \pm 9.6 \mathrm{Ma}$ with MSWD of 0.055 (Figure 3.11c), inferred as inherited zircon grains.

The subhedral zircon grains acquired from metavulcanosedimentary sample (CA38) have prismatic to equant habit and oscillatory compositional zoning characteristic of igneous growth (Figure 3.10c), with low Th/U ratios $(>0.1$ and $<1.0)$ are also compatible with an igneous origin (Table $\mathrm{S}_{4}$ ). But the generally subrounded shapes are typical for detrital grains. Most of the grains showed discordant ages. Among the concordant results, two grains gave a 1750-1850 Ma age and four zircons a 2100-2180 Ma (Figure 3.11d). These results suggest a 1800-1850 Ma maximum sedimentation age.

The zircon crystals from metarhyodacite CA39 are subhedral to euhedral, with prismatic to fragment habit and oscillatory compositional zoning characteristic of igneous growth, the 1.1, 2.1, 3.1 and 10.1 zircons (Figure 3.10e) display two growth zones, one discontinued and surrounded by newgrowth zoned, reflecting different conditions of $\mathrm{Zr}$ undersaturation (Corfu, 2003). The spots of SHRIMP analyses (Table $\left.\mathrm{S}_{5}\right)$, show low content of common $\mathrm{Pb}(<3 \%)$, and low $\mathrm{Th} / \mathrm{U}$ ratios $(>0.1$ and $<1.0)$, indicating equilibrium crystallization of the zircon crystals with the acid magma. Seven concordant $\mathrm{U}-\mathrm{Pb}$ spot analyses yield a Concordia age of $1761 \pm$ 14 Ma with MSWD of 2.5 (Figure 3.11e). 


\subsection{DISCUSSION}

\subsubsection{Tectonic setting of basic magmatism}

The metamafic rocks exhibit a tholeiite to calc-alkaline basic compositional trend, and due to the mobility of most LILE elements, their tectonic context and interpretation are deduced from the immobiles elements. The overall geochemical data suggest that the origin of the Itaiacoca Group metabasites is related with a Mid-Ocean Ridge environment with island-arc basalts components. Other characteristics that support this hypothesis are (following Pearce and Norry, 1979; Pearce and Peate, 1995; Chengli et al., 1995; Huang et al., 2001; Pearce, 2008): (1) In the spidergrams the metabasic rock are enriched in LILE (e.g., Th, $\mathrm{Ce}, \mathrm{Rb}, \mathrm{Pb}$ and $\mathrm{Ba}$ ) and depleted in HSFE (e.g., Zr, Hf, Y, Ti and Yb) elements relative to normal MORB rocks, characteristics in magmas formed by contribution of subduction zone components; (2) The REE patterns in diagram chondrite-normalized did no present Eu negative anomaly; (3) The $(\mathrm{Tb} / \mathrm{Yb})_{\mathrm{cn}}$ ratios between 1.1-1.4 indicated a moderate depletion in HREE and the presence of garnet as residual phase in the source; (4) The $\mathrm{La} / \mathrm{Nb}(1.0-2.2)$ and $\mathrm{Ce} / \mathrm{Nb}$ (2.3-4.9) ratios indicating MORB depleted mantle with back-arc basalts characteristics; (5) weak to moderate $\mathrm{Nb}$-Ta negative anomalies (Figure 3.8b) corroborate subduction-related contamination; (6) The high $\mathrm{Th} / \mathrm{Ta}$ (between 0.7-2.5) values and the $\mathrm{Th} / \mathrm{Yb}$ ratio (Figure 3.12c) indicate MORB-type mantle sources with heterogeneous contribution of subduction zone components; (7) the Ti and $\mathrm{V}$ contents (Figure 3.12d) are typical of both arc tholeiite and MORB and BABB environments; (8) the lower $\mathrm{Zr}$ and slightly lower $\mathrm{Zr} / \mathrm{Y}$ ratio (Figure 3.12b) suggest magmas derived of depleted source with partial melting, typical of basalt in Island arc and Mid-Ocean Ridges environments.

(a)

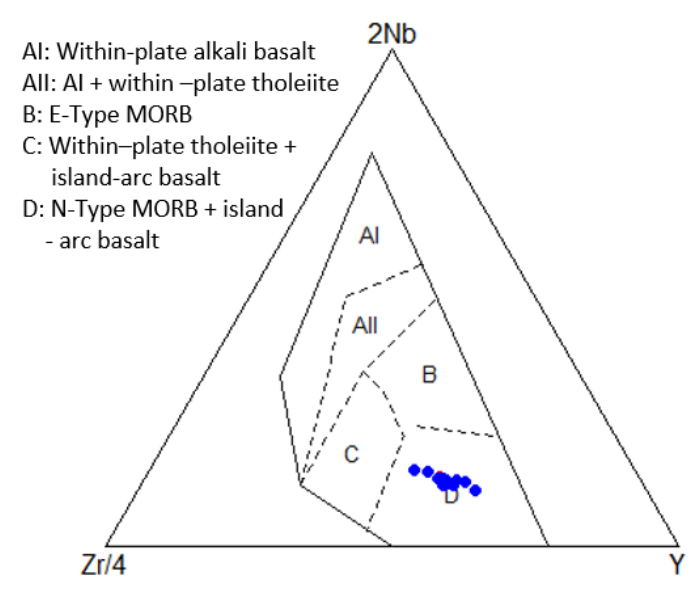

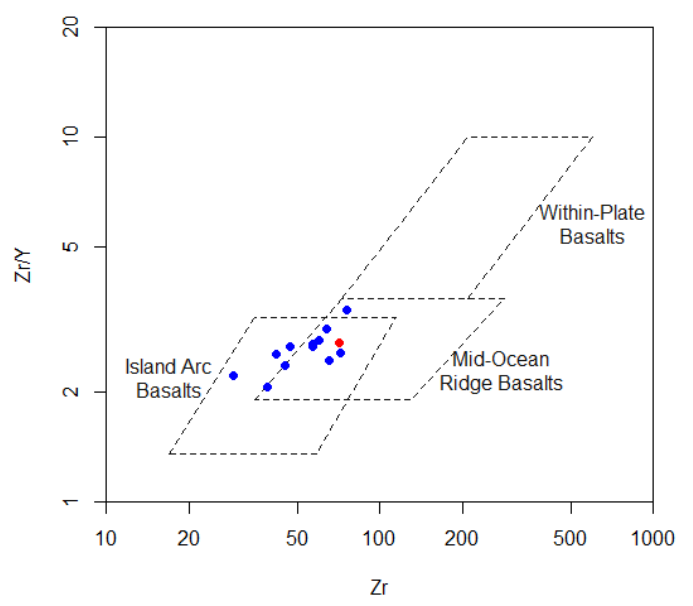




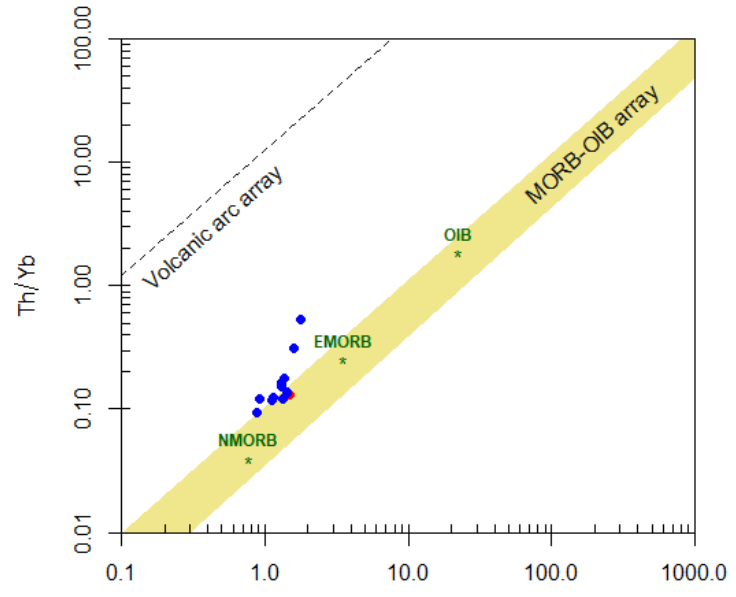

(c)

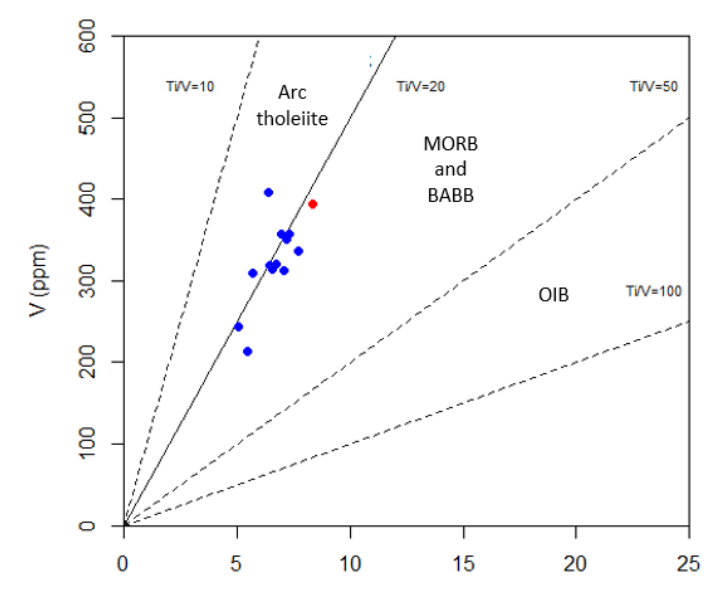

(d)

$\mathrm{Ti}(\mathrm{ppm}) / 1000$

Figure 3. 12. Tectonic discrimination diagrams of metabasites. (a) $\mathrm{Zr} / 4-2 \mathrm{Nb}-\mathrm{Y}$ plot (Meschede, 1986), (b) $\mathrm{Zr}-\mathrm{Zr} / \mathrm{Y}$ plot (Pearce and Norry, 1979), (c) $\mathrm{Nb} / \mathrm{Yb}-\mathrm{Th} / \mathrm{Yb}$ plot (Pearce, 2008) and (d) $\mathrm{V}(\mathrm{ppm}) / \mathrm{Ti}(\mathrm{ppm})$ plot (Shervais, 1982). In red, the CA1 sample.

The geochemical characteristic of the Itaiacoca Group metabasites are similar to the rocks found in Phanerozoic back-arc basin settings (e.g., Gill, 1976; Hawkesworth et al., 1977; Saunders and Tarney, 1984; Pearce, 1982; Pearce and Stern, 2006; Saunders and Tarney, 1984), which present MORB-type signatures with superimposed arc-type signatures, originated from depleted garnet lherzolite mantle with slight enrichment in LILE elements relative to HFSE elements and low Ta and Nb contents (Saunders and Tarney, 1984; Pearce and Stern, 2006; Helbig et al., 2013).

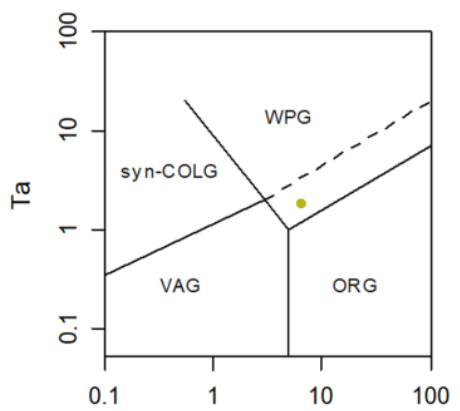

(a)।

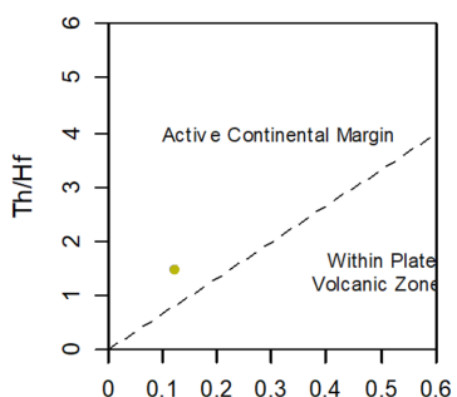

$\mathrm{Ta} / \mathrm{Hf}$

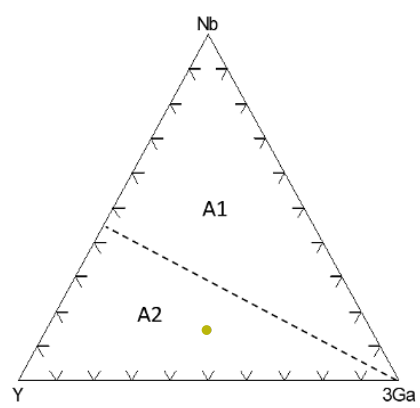

(c)

Figure 3. 13. Tectonomagmatic discrimination diagrams of metarhyodacite rocks. (a) $\mathrm{Ta}(\mathrm{ppm}) \mathrm{vs} \mathrm{Yb}$ (ppm) of Pearce et al. (1984), (b) Th/Hf - Ta/Hf plots of Schandle and Gorton (2002), and (c) Y-Nb$3^{*}$ Ga triangular diagrams of Eby (1992).

The Bairro dos Prestes Formation metarhyodacite sample shows chemical characteristics of intrusions derived from continental crust with subduction magmatism components (Figure 3.13). In the REE and multielement diagram (Figure 3.8), the metarhyodacite presents characteristics of High-K calc-alkaline granites, which be associated with magmatic arcs that could be formed in accretion, collisional and postcollisional stages. Its geochemical pattern is 
also similar with the Três Córregos Granitic Suite, interpreted as continental magmatic arc (Gimenez Filho, 1993; Gimenez Filho et al., 1995; Prazeres Filho et al., 2003; Prazeres Filho, 2005).

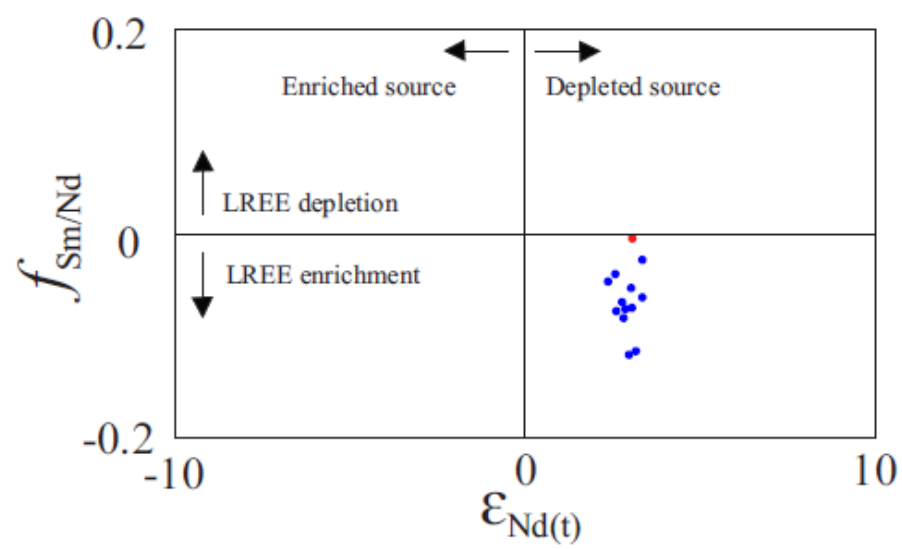

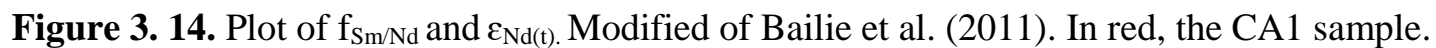

\subsubsection{Melt sources}

The Itaiacoca Group metabasite samples present $\mathrm{Sm} / \mathrm{Nd}$ ratios typical of basalts $(<0.32)$ (Faure, 1986). The ${ }^{143} \mathrm{Nd} /{ }^{144} \mathrm{Nd}$ ratios moderately higher than CHUR (DePaolo, 1988) and positive $\varepsilon \mathrm{N}_{\mathrm{d}(0)}$ and $\varepsilon \mathrm{N}_{\mathrm{d}(\mathrm{t})}$ values suggest that the protoliths of the metabasites rocks were derived from a slightly depleted magma source (DePaolo and Wasserburg, 1976; Faure, 1986; DePaolo, 1988; Faure, 2001; Wilson 2007) with LREE enrichment relative to CHUR (Figure 3.14), or generated from a reworked of Paleoproterozoic to Mesoproterozoic mafic protolith (average $\mathrm{T}_{\mathrm{DM}}$ model age of $1608 \mathrm{Ma})$.

The $\varepsilon \mathrm{N}_{\mathrm{d}(0)}$ values are concordant with the results obtained in analyses performed in basalts of back arc environments in which juvenile magma is generated with the progressive development of the basin (e.g., Ohki et al., 1994; Helbig et al., 2013).

The ${ }^{143} \mathrm{Nd} /{ }^{144} \mathrm{Nd}$ ratio of the Bairro dos Prestes metarhyodacite is lesser that the CHUR, and the negative $\varepsilon \mathrm{N}_{\mathrm{d}(0)}$ and $\varepsilon \mathrm{N}_{\mathrm{d}(\mathrm{t})}$ values indicate that the protolith of the sample was originated with contribution from crustal material fusion (Faure, 1986), possibly Neoarchean, as it is suggested by the $\mathrm{T}_{\mathrm{DM}}$ model age $(2537 \mathrm{Ma})$. 


\subsubsection{Ages of igneous crystallization, depositional and hydrothermal events}

The zircons of F135 and P13 samples generally are xenomorphic, unzoned or poorly zoned, typical of crystals development in late crystallization, a common pattern described in zircon grains from mafic rocks (e.g., Weber, 2004; Oliveira et al., 2008; Siga Jr et al., 2011; Campanha et al., 2015), although some crystals of sample P13 present rounded habits characteristic of detrital grains. Zircons of sample CA13 present prismatic habit with well-developed oscillatory zoning.

Two concordia ages were calculated for the F135 metabasic sample, one interpreted as the best estimative for the age of emplacement of the basic magmatism (571 $\pm 25 \mathrm{Ma}$, Figure 3.11a) of the Fazenda Velha Metabasic Suite, and the other interpreted as representing a hydrothermal event (Figure 3.3b) that affected the rock (486 \pm 9 Ma, Figure 3.10a). In the same way, although P13 metabasite presents an age distribution of inherited data typical of xenocrystals (Figure $3.11 \mathrm{~b}$ ), the youngest zircon age of ca. $860 \mathrm{Ma}$ is coherent with magmatic crystallization of the host metamafic rock in the Neoproterozoic period, as it is also suggested in the isochronic age calculated from Sm-Nd data (Figure 3.9).

Given the stratigraphic relationship of the CA13 metatuff sample with the adjacent units (small beds intercalated with phyllites and carbonatic rocks), we infer the age of $613 \pm 10 \mathrm{Ma}$ (Figure 3.11c) as the sedimentation age of the pelitic and carbonatic succession of Itaiacoca Group.

The zircons of CA38 and CA39 samples present prismatic habit with well-developed oscillatory zoning, however the crystals of the metavolcanosedimentary sample show round borders typically of detrital grains (Figure 3.10c, e). The geochronological data yield ages in the Statherian period (1761-1805 Ma interval) for the deposition of the Bairro dos Prestes Formation represented by the crystallization (1761 $\pm 14 \mathrm{Ma}$, Figure 3.11e) and maximum depositional age (the youngest detrital zircon, $1805 \pm 35 \mathrm{Ma}$, Figure 3.11d) of the metarhyodacite and metavolcanosedimentary rock, respectively.

\subsubsection{Regional geotectonic implications}

The results here obtained point to the separation of the here named Bairro dos Prestes Formation from the Itaiacoca Group based on the large difference in lithological associations and volcanic ages: while the sedimentation of the Fazenda Velha Metabasic Suite and Bairro dos Campos Formation of the Itaiacoca Group lay in the 571-613 Ma age interval, the Bairro dos Prestes Formation has a 1760-1800 Ma sedimentation and volcanic age. 
The ages obtained for the Itaiacoca Group rocks (Bairro dos Campos Formation and Fazenda Velha metabasic Suite) are in part similar to those from Abapã Formation in the southwestern portion of the Itaiacoca Group (Paraná state), but they disagree with respect to the metabasites ages from that region (Siga Jr et al., 2003, 2009, 2010, 2011c). In the same way, our geochronological data of the Itaiacoca Group contrast with some data from the metasedimentary units of the Apiaí terrane, as the Água Clara Formation (Weber et al., 2004), Lajeado (Campanha et al., 2016) and Votuverava (Siga Jr et al., 2011; Campanha et al., 2015) groups, which have shown mainly Mesoproterozoic sedimentation ages, but with expressive Ediacaran arc-related granitic magmatism, metamorphism and transcurrent-related deformation (Hackspacher et al., 2000; Janasi et al., 2001;Prazeres Filho, 2005; Faleiros et al., 2010, 2011). However, they are similar with the calculated ages for some units of the Curitiba Terrane, south of the Lancinha-Cubatão shear zone, especially the Turvo-Cajati Formation that has metapelitic rocks with a youngest detrital zircon population with $\mathrm{U}-\mathrm{Pb}$ ages of ca. $630 \mathrm{Ma}$ (Faleiros et al., 2016), although perhaps somewhat younger than those from the Capirú Formation which has been speculatively age-correlated by some authors with the Itaiacoca Group (Almeida, 1956; Bigarella and Salamuni, 1956, Petri and Suguio, 1969; Hasui, 1986; Campanha, 1991; Fassbinder, 1996; Campanha and Sadowski, 1999).

The age obtained for the Bairro dos Prestes Formation is similar to that from the neighboring Apiaí-Mirim Complex (Prazeres Filho, 2005; Siga Jr, 2010) but the latter is primarily composed of orthogneiss, while its surrounding metasedimentary rocks are generally attributed to the Água Clara Formation which in turn has a 1590 - 1470 Ma age (Weber et al., 2004).

Geochronological data and geochemical signature results, as well the similar sedimentary and volcanic environments suggest a possible correlation between part of the Açungui Supergroup and São Roque Group (Moraes, 1933; Almeida, 1944; Coutinho, 1968a, 1968b, 1971; Hasui, 1973). There is no physical continuity between them because their connection region is covered by the Paleozoic sedimentary flat-lying rocks of the Paraná basin (Figure 3.1). The Pirapora do Bom Jesus Formation from São Roque Group and Itaiacoca Group (in Pirapora do Bom Jesus and Itapeva region, respectively) were metamorphosed under greenschists facies conditions, and comprise significant amounts of metabasic rocks, intercalated with pelitic-dolomitic successions with stromatolites and other shallow water structures (Bergmann and Fairchild, 1985, 1986, Bergmann, 1988), suggesting a common depositional environment-type. The association of bodies of metabasalt covered by stromatolitic dolomite suggests the existence of oceanic islands and associated shallow water deposits. Available zircon $\mathrm{U}-\mathrm{Pb}$ ages obtained 
from metabasalt samples from the Pirapora do Bom Jesus Formation (608 \pm 7 Ma and $628 \pm 9$ Ma; Hasckspacher et al., 1999, 2000) and Itaiacoca Group (571 \pm 25 Ma and $613 \pm 10$ Ma; this work), indicate that both units are chronocorrelated and deposited during the Ediacaran. Additionally, the overall geochemical patterns from the Pirapora do Bom Jesus (Figueiredo et al., 1982; Lazzari, 1987; Hasckspacher et al., 1999, 2000; Juliani et al, 2000; Tassinari et al., 2001) and Itaiacoca Formation (this work) metabasites are coherent with a back-arc basin magmatic setting.

$\mathrm{U}-\mathrm{Pb}$ ages and geochemical signature of the metavolcanosedimentary rock and metarhyodacite samples of the Bairro dos Prestes Formation also allow a correlation between the Bairro dos Prestes Formation and part of the São Roque Group, a major unit from the central Ribeira Belt. The Boturuna Formation (São Roque Group) and Bairro dos Prestes Formation (in Morro do Polvilho and Itapeva regions, respectively), were affected by a greenschist facies metamorphism, and are composed of intercalations of acid metavolcanic rocks in packages dominated by phyllites and quartzites, with age of $1790 \pm 14$ Ma (Van Schmus et al., 1986),

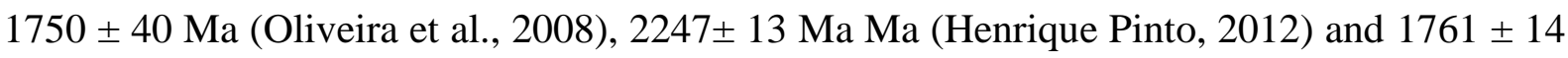
$\mathrm{Ma}$ (this work), related with felsic to intermediate volcanism with chemical characteristics typical of High-K calc-alkaline granites of magmatic arcs (Delgado et al., 2003; Henrique-Pinto and Janasi, 2010; this work).

The arc-back-arc basin environment implies the existence of an oceanic islands, which involve the existence of a large Ediacaran ocean (Ocean Adamastor). In this context, the location of the Itaiacoca Group in the north of the Apiaí Terrain also suggests the existence of a suture zone between this and the Paranapanema Craton, indicating for the first time that this tectonic collage is Ediacarana.

\subsection{CONCLUSIONS}

Geochronological data obtained from metabasites $(571 \pm 25 \mathrm{Ma})$ and metatuff $(613 \pm 10 \mathrm{Ma})$ sample of Itaiacoca Group suggest Neoproterozoic ages for the emplacement of basic magmatism and deposition of pelitic and carbonatic succession. While, SHRIMP U-Pb zircon geochronology on a metarhyodacite and metavolcanosedimentary of Bairro dos Prestes Formation yield ages of $1761 \pm 14$ and $1805 \pm 35 \mathrm{Ma}$, interpreted as crystallization and depositional ages, respectively, of this unit. 
The geochemistry characterization based on trace and rare elements and $\mathrm{Sm}-\mathrm{Nd}$ isotopic system suggest tholeiitic to calc-alkaline signatures for the Itaiacoca Group metabasites, with emplacement in a back-arc basin setting also coherent with the field geological data. The positive $\varepsilon \mathrm{N}_{\mathrm{d}(\mathrm{t})}$ values $(+2.3-+3.2)$, imply a common juvenile mantle source to the basic magmatism, while trace element data suggest a dominant MORB-type mantle source with heterogeneous contribution of subduction zone components, also corroborating a back-arc setting environment. Zircon SHRIMP U-Pb data indicate an Ediacaran age interval of 570-615 Ma for back-arc basin basic volcanic magmatism and deposition of part of the Itaiacoca Group. The Bairro dos Prestes Formation is here defined in the region between Itapeva and Ribeirão Branco and we propose its separation from the Itaiacoca Group due their large differences in depositional settings and volcanic ages. The Bairro dos Prestes Formation is comprised of phyllites with sometimes amygdaloid structures, fine to medium grained-quartzites, and restricted occurrences of metarhyodacite and metaconglomerate.

The Bairro dos Prestes metarhyodacite presents metaluminous character with geochemical signatures of high-K calc-alkaline magma series, whereas negative $\varepsilon \mathrm{N}_{\mathrm{d}(\mathrm{t})}$ values (-6.8), suggest the recycling of Neoarchean continental crust ( $\mathrm{T}_{\mathrm{DM}}$ model age of $2537 \mathrm{Ma}$ ).

$\mathrm{U}-\mathrm{Pb}$ age data and geochemical as the geological context suggest that the Itaiacoca Group can be correlated with Pirapora do Bom Jesus Formation of São Roque Group (dated in 608-628 Ma period), deposited in back-arc environment and amalgamated during the Brasiliano/Pan African Orogeny in the Late Neoproterozoic, and the Bairro dos Prestes Formation is correlated with Boturuna Formation of São Roque Group, with deposition age between $1750 \mathrm{Ma}$ and 1790 Ma. The Itaiacoca Group and Pirapora do Bom Jesus Formation are both inferred as remnants of an arc-back-arc basin system associated with the large Adamastor Ocean, and an Ediacaran suture zone between the Apiaí Terrane and the Paranapanema Craton. 
Table $\mathbf{S}_{1}$. Analytical SHRIMP results for metabasite sample F135 of the Fazenda Velha Metabasic Suite of the Itaiacoca Group.

\begin{tabular}{|c|c|c|c|c|c|c|c|c|c|c|c|c|c|c|c|c|c|c|c|}
\hline \multirow{2}{*}{ Spot } & \multirow{2}{*}{ Site } & \multirow{2}{*}{$\begin{array}{c}\mathrm{U} \\
(\mathrm{ppm})\end{array}$} & \multirow{2}{*}{$\begin{array}{c}\text { Th } \\
(\mathrm{ppm})\end{array}$} & \multirow{2}{*}{$\mathrm{Th} / \mathrm{U}$} & \multirow{2}{*}{$\begin{array}{c}{ }^{206} \mathrm{~Pb} \\
(\%)\end{array}$} & \multirow{2}{*}{$\begin{array}{l}{ }^{206} \mathrm{~Pb} \\
(\mathrm{ppm})\end{array}$} & \multirow{2}{*}{${ }^{206} \mathrm{~Pb} /{ }^{238} \mathrm{U}$} & \multirow{2}{*}{ Error } & \multirow{2}{*}{${ }^{207} \mathrm{~Pb} /{ }^{235} \mathrm{U}$} & \multirow{2}{*}{ Error } & \multirow{2}{*}{${ }^{207} \mathrm{~Pb} /{ }^{206} \mathrm{~Pb}$} & \multirow{2}{*}{ Error } & \multirow{2}{*}{${ }^{238} \mathrm{U} /{ }^{206} \mathrm{~Pb}$} & \multirow{2}{*}{ Error } & \multicolumn{4}{|c|}{ Age } & \multirow{2}{*}{$\begin{array}{r}\text { Conc. } \\
(\%)\end{array}$} \\
\hline & & & & & & & & & & & & & & & ${ }^{206} \mathrm{~Pb} /{ }^{238} \mathrm{U}$ & Error & ${ }^{207} \mathrm{~Pb} /{ }^{206} \mathrm{~Pb}$ & Error & \\
\hline 1.1 & $\mathrm{e}, \mathrm{osc} / \mathrm{r}, \mathrm{p} / \mathrm{rd}$ & 129 & 57 & 0.44 & 0.38 & 26.2 & 0.235 & 1.5 & 2.82 & 1.9 & 0.087 & 1.1 & 4.3 & 1.5 & 1362 & 19 & 1357 & 21 & 100 \\
\hline 1.2 & $\mathrm{~m}, \mathrm{sz} / \mathrm{hb}, \mathrm{p} / \mathrm{rd}$ & 434 & 35 & 0.80 & 1.41 & 44.3 & 0.119 & 1.4 & 1.08 & 2.3 & 0.066 & 1.8 & 8.4 & 1.4 & 726 & 10 & 800 & 39 & 90 \\
\hline 2.1 & $\mathrm{e}, \mathrm{osc} / \mathrm{r}, \mathrm{eq} / \mathrm{rd}$ & 134 & 32 & 0.24 & 2.47 & 37.2 & 0.331 & 1.5 & 5.93 & 1.7 & 0.130 & 0.6 & 3.0 & 1.5 & 1843 & 24 & 2099 & 11 & 86 \\
\hline 2.2 & $\mathrm{~m}, \mathrm{osc} / \mathrm{r}, \mathrm{eq} / \mathrm{rd}$ & 193 & 84 & 0.43 & 1.79 & 58.2 & 0.357 & 1.5 & 6.56 & 1.6 & 0.133 & 0.5 & 2.8 & 1.5 & 1967 & 25 & 2141 & 8 & 91 \\
\hline 3.1 & $\mathrm{e}, \mathrm{osc} / \mathrm{r}, \mathrm{anh} / \mathrm{rd}$ & 351 & 19 & 0.05 & 1.11 & 35.2 & 0.117 & 1.4 & 1.07 & 2.2 & 0.066 & 1.7 & 8.5 & 1.4 & 714 & 10 & 818 & 35 & 87 \\
\hline 3.2 & $\mathrm{~m}, \mathrm{osc}, \mathrm{anh} / \mathrm{rd}$ & 167 & 110 & 0.66 & 1.09 & 45.9 & 0.321 & 1.5 & 5.10 & 2.7 & 0.115 & 2.3 & 3.1 & 1.5 & 1796 & 24 & 1883 & 41 & 95 \\
\hline 4.1 & $\mathrm{~m}, \mathrm{hb}, \mathrm{eq} / \mathrm{rd}$ & 247 & 96 & 0.39 & 1.18 & 19.2 & 0.091 & 1.5 & 0.73 & 3.6 & 0.059 & 3.2 & 11.0 & 1.5 & 559 & 8 & 562 & 71 & 99 \\
\hline 4.2 & $\mathrm{c}, \mathrm{hd}, \mathrm{eq} / \mathrm{rd}$ & 353 & 161 & 0.46 & 1.03 & 27.1 & 0.090 & 1.4 & 0.74 & 3.7 & 0.060 & 3.4 & 11.2 & 1.4 & 553 & 8 & 606 & 73 & 91 \\
\hline 5.1 & $\mathrm{c}, \mathrm{hd}, \mathrm{fr} / \mathrm{rd}$ & 460 & 255 & 0.55 & 0.93 & 35.9 & 0.091 & 1.4 & 0.76 & 4.0 & 0.061 & 3.7 & 11.0 & 1.4 & 562 & 8 & 632 & 80 & 88 \\
\hline 6.1 & $\mathrm{e}, \mathrm{osc} / \mathrm{r}, \mathrm{eq} / \mathrm{rd}$ & 522 & 366 & 0.70 & 4.05 & 31.8 & 0.071 & 1.6 & 0.58 & 7.9 & 0.059 & 7.7 & 14.0 & 1.6 & 443 & 7 & 566 & 169 & 78 \\
\hline 6.2 & $\mathrm{e}, \mathrm{hb}, \mathrm{eq} / \mathrm{rd}$ & 106 & 124 & 1.17 & 0.63 & 7.2 & 0.079 & 1.6 & 0.62 & 7 & 0.058 & 6.8 & 12.7 & 1.6 & 488 & 7 & 514 & 150 & 95 \\
\hline 7.1 & $\mathrm{e}, \mathrm{osc} / \mathrm{r}$, anh & 490 & 238 & 0.48 & 4.59 & 34.3 & 0.082 & 2.2 & 0.67 & 13.9 & 0.059 & 13.8 & 12.2 & 2.2 & 506 & 11 & 575 & 299 & 88 \\
\hline 7.2 & $\mathrm{c}, \mathrm{sz} / \mathrm{hb}$, anh & 165 & 177 & 1.07 & 1.95 & 10.5 & 0.074 & 1.6 & 0.59 & 6.9 & 0.058 & 6.7 & 13.5 & 1.6 & 460 & 7 & 532 & 147 & 86 \\
\hline 8.1 & $\mathrm{e}, \mathrm{osc}, \mathrm{fr}$ & 150 & 99 & 0.66 & 2.54 & 15.3 & 0.119 & 1.6 & 1.06 & 5.3 & 0.065 & 5.1 & 8.4 & 1.6 & 726 & 11 & 764 & 107 & 95 \\
\hline 9.1 & $\mathrm{~m}, \mathrm{hb}, \mathrm{eq} / \mathrm{rd}$ & 247 & 119 & 0.48 & 0.54 & 16.7 & 0.079 & 1.5 & 0.61 & 2.9 & 0.056 & 2.5 & 12.7 & 1.5 & 488 & 7 & 468 & 55 & 105 \\
\hline 10.1 & $\mathrm{c}, \mathrm{ic}, \mathrm{rd}$ & 453 & 294 & 0.65 & 0.57 & 38.7 & 0.1 & 1.4 & 0.86 & 1.8 & 0.062 & 1.1 & 10 & 1.4 & 612 & 8 & 691 & 24 & 88 \\
\hline 11.1 & $\mathrm{~m}, \mathrm{hd}, \mathrm{fr} / \mathrm{rd}$ & 563 & 1078 & 1.91 & 0.42 & 37.5 & 0.078 & 1.8 & 0.61 & 2.3 & 0.057 & 1.4 & 12.9 & 1.8 & 482 & 8 & 488 & 30 & 99 \\
\hline 12.1 & $\mathrm{e}, \mathrm{hb}, \mathrm{ov} / \mathrm{rd}$ & 312 & 91 & 0.29 & 1.48 & 26.1 & 0.098 & 1.5 & 0.83 & 3.7 & 0.062 & 3.4 & 10.2 & 1.5 & 601 & 8 & 669 & 73 & 89 \\
\hline 13.1 & $\mathrm{c}, \mathrm{ic}, \mathrm{ov} / \mathrm{rd}$ & 395 & 214 & 0.54 & 0.95 & 32.2 & 0.095 & 1.4 & 0.79 & 3.5 & 0.061 & 3.2 & 10.5 & 1.4 & 585 & 8 & 628 & 70 & 93 \\
\hline
\end{tabular}

Site: $\mathrm{m}$, middle; e, end or egde.

Grain habit: p, prism; rd, round; ov, ovoide; eq, equant; fr, fragment; anh, anhedral.

CL petrography: osc, oscillatory zoning; hb, homogeneous bright; hd, homogeneous dark; sz, sector zoning; r, rim/overgrowth.

$\mathrm{Pb}(\%)$ and ${ }^{206} \mathrm{~Pb}(\mathrm{ppm})$, indicate the common and radiogenic portions, respectively. All errors are 1-sigma. 
Table $\mathbf{S}_{2}$. Analytical SHRIMP results for metabasite sample P13 of the Fazenda Velha Metabasic Suite of the Itaiacoca Group.

\begin{tabular}{|c|c|c|c|c|c|c|c|c|c|c|c|c|c|c|c|c|c|c|c|}
\hline \multirow{2}{*}{ Spot } & \multirow{2}{*}{ Site } & \multirow{2}{*}{$\begin{array}{c}\mathrm{U} \\
(\mathrm{ppm})\end{array}$} & \multirow{2}{*}{$\begin{array}{c}\text { Th } \\
\text { (ppm) }\end{array}$} & \multirow{2}{*}{$\mathrm{Th} / \mathrm{U}$} & \multirow{2}{*}{$\begin{array}{c}{ }^{206} \mathrm{~Pb} \\
(\%)\end{array}$} & \multirow{2}{*}{$\begin{array}{l}{ }^{206} \mathrm{~Pb} \\
(\mathrm{ppm})\end{array}$} & \multirow{2}{*}{${ }^{206} \mathrm{~Pb} /{ }^{238} \mathrm{U}$} & \multirow{2}{*}{ Error } & \multirow{2}{*}{${ }^{207} \mathrm{~Pb} /{ }^{235} \mathrm{U}$} & \multirow{2}{*}{ Error } & \multirow{2}{*}{${ }^{207} \mathrm{~Pb} /{ }^{206} \mathrm{~Pb}$} & \multirow{2}{*}{ Error } & \multirow{2}{*}{${ }^{238} \mathrm{U} /{ }^{206} \mathrm{~Pb}$} & \multirow{2}{*}{ Error } & \multicolumn{4}{|c|}{ Age } & \multirow{2}{*}{$\begin{array}{c}\text { Conc. } \\
(\%)\end{array}$} \\
\hline & & & & & & & & & & & & & & & ${ }^{206} \mathrm{~Pb} /{ }^{238} \mathrm{U}$ & Error & ${ }^{207} \mathrm{~Pb} /{ }^{206} \mathrm{~Pb}$ & Error & \\
\hline 1.1 & $\mathrm{e}, \mathrm{hd}$, anh & 225 & 1922 & 8.54 & 1.48 & 30 & 0.155 & 1.9 & 1.6 & 2.8 & 0.073 & 2.1 & 6.5 & 1.9 & 929 & 16 & 1023 & 42 & 90 \\
\hline 1.2 & $\mathrm{n}, \mathrm{hd}$, anh & 990 & 796 & 0.80 & 0.99 & 166 & 0.197 & 1.1 & 2.2 & 1.2 & 0.082 & 0.6 & 5.1 & 1.1 & 1157 & 12 & 1254 & 11 & 92 \\
\hline 2.1 & $\mathrm{e}, \mathrm{osc}$, anh & 286 & 145 & 0.51 & -0.09 & 69 & 0.280 & 1.1 & 3.7 & 1.2 & 0.097 & 0.6 & 3.6 & 1.1 & 1591 & 16 & 1567 & 10 & 102 \\
\hline 3.1 & $\mathrm{e}, \mathrm{r}, \mathrm{ov} / \mathrm{rd}$ & 301 & 128 & 0.42 & -0.31 & 101 & 0.389 & 0.9 & 6.9 & 1.0 & 0.129 & 0.4 & 2.6 & 0.9 & 2116 & 16 & 2080 & 7 & 102 \\
\hline 4.1 & $\mathrm{e}, \mathrm{osc}, \mathrm{anh}$ & 576 & 1327 & 2.30 & 1.17 & 94 & 0.192 & 0.9 & 2.2 & 1.1 & 0.083 & 0.8 & 5.2 & 0.9 & 1132 & 9 & 1259 & 15 & 89 \\
\hline 5.1 & $\mathrm{e}, \mathrm{hd}$, anh & 425 & 368 & 0.86 & 0.18 & 109 & 0.297 & 0.9 & 4.1 & 1.4 & 0.101 & 1.0 & 3.4 & 0.9 & 1674 & 13 & 1636 & 19 & 103 \\
\hline 6.1 & $\mathrm{e}, \mathrm{hb}, \mathrm{ov}$ & 130 & 72 & 0.55 & 2.63 & 48 & 0.444 & 1.1 & 10.3 & 2.1 & 0.168 & 1.8 & 2.3 & 1.1 & 2370 & 21 & 2542 & 29 & 92 \\
\hline 7.1 & $\mathrm{~m}, \mathrm{hd}, \mathrm{anh}$ & 623 & 418 & 0.67 & 1.57 & 179 & 0.340 & 0.8 & 6.0 & 0.9 & 0.127 & 0.3 & 2.9 & 0.8 & 1886 & 14 & 2057 & 5 & 90 \\
\hline 8.1 & $\mathrm{n}, \mathrm{hd}, \mathrm{anh}$ & 778 & 901 & 1.16 & 1.84 & 133 & 0.200 & 1.2 & 2.4 & 1.4 & 0.085 & 0.8 & 5.0 & 1.2 & 1176 & 13 & 1324 & 16 & 88 \\
\hline 9.1 & $\mathrm{e}, \mathrm{hd}, \mathrm{anh}$ & 895 & 512 & 0.57 & 2.17 & 131 & 0.173 & 1.5 & 2.0 & 1.7 & 0.083 & 0.8 & 5.8 & 1.5 & 1026 & 14 & 1270 & 16 & 79 \\
\hline 10.1 & $\mathrm{n}, \mathrm{hd}$, anh & 577 & 774 & 1.34 & 1.83 & 103 & 0.210 & 1.1 & 2.5 & 2.4 & 0.088 & 2.1 & 4.8 & 1.1 & 1229 & 13 & 1373 & 41 & 88 \\
\hline 11.1 & $\mathrm{e}, \mathrm{osc} / \mathrm{r}, \mathrm{p} / \mathrm{rd}$ & 259 & 144 & 0.56 & 2.12 & 143 & 0.660 & 0.9 & 24.8 & 0.9 & 0.273 & 0.2 & 1.5 & 0.9 & 3265 & 23 & 3321 & 4 & 98 \\
\hline 12.1 & $\mathrm{e}, \mathrm{hd}, \mathrm{anh} / \mathrm{rd}$ & 478 & 2057 & 4.30 & 2.66 & 59 & 0.143 & 1.2 & 1.4 & 2.3 & 0.072 & 2.0 & 7.0 & 1.2 & 864 & 10 & 998 & 40 & 86 \\
\hline 13.1 & $\mathrm{n}, \mathrm{hd}$, anh & 618 & 1237 & 2.00 & 0.91 & 113 & 0.213 & 0.8 & 2.5 & 1.1 & 0.085 & 0.7 & 4.7 & 0.8 & 1245 & 9 & 1327 & 14 & 93 \\
\hline 14.1 & $\mathrm{e}, \mathrm{hd}, \mathrm{anh}$ & 511 & 363 & 0.71 & 0.61 & 113 & 0.258 & 0.8 & 3.4 & 1.0 & 0.096 & 0.5 & 3.9 & 0.8 & 1478 & 11 & 1544 & 9 & 95 \\
\hline 15.1 & $\mathrm{e}, \mathrm{osc} / \mathrm{r}, \mathrm{eq} / \mathrm{rd}$ & 105 & 152 & 1.45 & 2.12 & 143 & 0.445 & 4.0 & 8.6 & 4.3 & 0.141 & 1.4 & 2.2 & 4.0 & 2371 & 80 & 2236 & 24 & 107 \\
\hline 16.1 & $\mathrm{~m}, \mathrm{sz} / \mathrm{hd}, \mathrm{eq} / \mathrm{rd}$ & 368 & 191 & 0.52 & -0.52 & 126 & 0.395 & 0.9 & 7.1 & 0.9 & 0.130 & 0.4 & 2.5 & 0.9 & 2148 & 16 & 2095 & 6 & 103 \\
\hline 17.1 & $\mathrm{e}, \mathrm{hd}, \mathrm{fr}$ & 506 & 1246 & 2.46 & 0.03 & 122 & 0.282 & 1.2 & 3.8 & 1.2 & 0.098 & 0.4 & 3.6 & 1.2 & 1600 & 17 & 1595 & 8 & 100 \\
\hline
\end{tabular}

Site: $\mathrm{m}$, middle; e, end or egde.

Grain habit: p, prism; rd, round; ov, ovoide; eq, equant; fr, fragment; anh, anhedral.

CL petrography: osc, oscillatory zoning; hb, h omogeneous bright; hd, homogeneous dark; sz, sector zoning; r, rim/overgrowth.

$\mathrm{Pb}(\%)$ and ${ }^{206} \mathrm{~Pb}(\mathrm{ppm})$, indicate the common and radiogenic portions, respectively. All errors are 1-sigma. 
Table $\mathbf{S}_{3}$. Analytical SHRIMP results for metatuff sample CA13 of the Bairro dos Campos Formation of the Itaiacoca Group.

\begin{tabular}{|c|c|c|c|c|c|c|c|c|c|c|c|c|c|c|c|c|c|c|c|}
\hline \multirow{2}{*}{ Spot } & \multirow{2}{*}{ Site } & \multirow{2}{*}{$\begin{array}{c}\mathrm{U} \\
(\mathrm{ppm})\end{array}$} & \multirow{2}{*}{$\begin{array}{c}\text { Th } \\
\text { (ppm) }\end{array}$} & \multirow{2}{*}{$\mathrm{Th} / \mathrm{U}$} & \multirow{2}{*}{$\begin{array}{c}{ }^{206} \mathrm{~Pb} \\
(\%)\end{array}$} & \multirow{2}{*}{$\begin{array}{l}{ }^{206} \mathrm{~Pb} \\
(\mathrm{ppm})\end{array}$} & \multirow{2}{*}{${ }^{206} \mathrm{~Pb} /{ }^{238} \mathrm{U}$} & \multirow{2}{*}{ Error } & \multirow{2}{*}{${ }^{207} \mathrm{~Pb} /{ }^{235} \mathrm{U}$} & \multirow{2}{*}{ Error } & \multirow{2}{*}{${ }^{207} \mathrm{~Pb} /{ }^{206} \mathrm{~Pb}$} & \multirow{2}{*}{ Error } & \multirow{2}{*}{${ }^{238} \mathrm{U} /{ }^{206} \mathrm{~Pb}$} & \multirow{2}{*}{ Error } & \multicolumn{4}{|c|}{ Age } & \multirow{2}{*}{$\begin{array}{r}\text { Conc } \\
(\%)\end{array}$} \\
\hline & & & & & & & & & & & & & & & ${ }^{206} \mathrm{~Pb} /{ }^{238} \mathrm{U}$ & Error & ${ }^{207} \mathrm{~Pb} /{ }^{206} \mathrm{~Pb}$ & Error & \\
\hline 1.1 & $\mathrm{e}, \mathrm{osc} / \mathrm{r}, \mathrm{p} / \mathrm{rd}$ & 792 & 698 & 0.88 & 2.60 & 62 & 0.091 & 1.2 & 0.8 & 3.7 & 0.061 & 3.6 & 11.0 & 1.2 & 561 & 6 & 650 & 77 & 86 \\
\hline 2.1 & $\mathrm{e}, \mathrm{osc} / \mathrm{r}, \mathrm{anh} / \mathrm{rd}$ & 1239 & 134 & 0.11 & 8.81 & 153 & 0.149 & 1.1 & 1.9 & 4.6 & 0.093 & 4.5 & 6.7 & 1.1 & 893 & 9 & 1491 & 85 & 57 \\
\hline 3.1 & $\mathrm{e}, \mathrm{osc} / \mathrm{r} / \mathrm{hb}, \mathrm{fr} / \mathrm{rd}$ & 418 & 124 & 0.29 & 7.72 & 31 & 0.087 & 1.6 & 0.7 & 9.9 & 0.062 & 9.7 & 11.5 & 1.6 & 536 & 8 & 670 & 209 & 79 \\
\hline 4.1 & $\mathrm{e}, \mathrm{osc} / \mathrm{hd}, \mathrm{p} / \mathrm{rd} / \mathrm{fr}$ & 343 & 161 & 0.47 & 0.52 & 30 & 0.1 & 0.9 & 0.8 & 2 & 0.06 & 1.7 & 10 & 0.9 & 616 & 5 & 614 & 38 & 100 \\
\hline 5.1 & $\mathrm{e}, \mathrm{osc} / \mathrm{r}, \mathrm{fr} / \mathrm{rd}$ & 467 & 398 & 0.85 & 1.80 & 87 & 0.218 & 1.1 & 2.5 & 2.4 & 0.082 & 2.1 & 4.6 & 1.1 & 1269 & 12 & 1256 & 41 & 101 \\
\hline 6.1 & $\mathrm{e}, \mathrm{osc}, \mathrm{p} / \mathrm{rd} / \mathrm{fr}$ & 396 & 178 & 0.45 & 1.92 & 35 & 0.102 & 0.9 & 0.9 & 3.3 & 0.061 & 3.1 & 9.8 & 0.9 & 627 & 5 & 636 & 67 & 99 \\
\hline 7.1 & $\mathrm{e}, \mathrm{osc}, \mathrm{eq} / \mathrm{rd} / \mathrm{fr}$ & 463 & 324 & 0.70 & 0.38 & 39 & 0.098 & 0.9 & 0.8 & 2.5 & 0.06 & 2.4 & 10.2 & 0.9 & 605 & 5 & 615 & 52 & 98 \\
\hline 8.1 & $\mathrm{e}, \mathrm{osc} / \mathrm{hb}, \mathrm{fr} / \mathrm{rd}$ & 473 & 60 & 0.13 & 0.60 & 157 & 0.387 & 1.0 & 7.0 & 1.4 & 0.131 & 0.9 & 2.6 & 1.0 & 2109 & 19 & 2108 & 16 & 100 \\
\hline 9.1 & $\mathrm{e}, \mathrm{osc}, \mathrm{eq} / \mathrm{rd} / \mathrm{fr}$ & 91 & 43 & 0.47 & 0.7 & 8 & 0.096 & 1.7 & 0.8 & 6.1 & 0.062 & 5.8 & 10.4 & 1.7 & 594 & 9 & 658 & 125 & 90 \\
\hline 10.1 & $\mathrm{e}, \mathrm{osc} / \mathrm{r}, \mathrm{fr} / \mathrm{rd}$ & 208 & 81 & 0.39 & 2.06 & 20 & 0.111 & 1.2 & 1.0 & 5.7 & 0.064 & 5.6 & 9.0 & 1.2 & 679 & 8 & 726 & 119 & 93 \\
\hline
\end{tabular}

Site: $\mathrm{m}$, middle; e, end or egde.

Grain habit: p, prism; rd, round; ov, ovoide; eq, equant; fr, fragment; anh, anhedral.

CL petrography: osc, oscillatory zoning; hb, homogeneous bright; hd, homogeneous dark; sz, sector zoning; r, rim/overgrowth.

$\mathrm{Pb}(\%)$ and ${ }^{206} \mathrm{~Pb}(\mathrm{ppm})$, indicate the common and radiogenic portions, respectively. All errors are 1-sigma. 
Table $\mathbf{S}_{4}$ U-Pb isotopic data results for metavolcanosedimentar sample CA38 of the Bairro dos Prestes Formation.

\begin{tabular}{|c|c|c|c|c|c|c|c|c|c|c|c|c|c|c|c|c|c|c|c|}
\hline \multirow{2}{*}{ Spot } & \multirow{2}{*}{ Site } & \multirow{2}{*}{$\begin{array}{c}\mathrm{U} \\
(\mathrm{ppm})\end{array}$} & \multirow{2}{*}{$\begin{array}{c}\text { Th } \\
(\mathrm{ppm})\end{array}$} & \multirow{2}{*}{$\mathrm{Th} / \mathrm{U}$} & \multirow{2}{*}{$\begin{array}{c}{ }^{206} \mathrm{~Pb} \\
(\%)\end{array}$} & \multirow{2}{*}{$\begin{array}{l}{ }^{206} \mathrm{~Pb} \\
(\mathrm{ppm})\end{array}$} & \multirow{2}{*}{${ }^{206} \mathrm{~Pb} /{ }^{238} \mathrm{U}$} & \multirow{2}{*}{ Error } & \multirow{2}{*}{${ }^{207} \mathrm{~Pb} /{ }^{235} \mathrm{U}$} & \multirow{2}{*}{$r \cdots-r$} & \multirow{2}{*}{${ }^{207} \mathrm{~Pb} /{ }^{206} \mathrm{~Pb}$} & \multirow{2}{*}{ Error } & \multirow{2}{*}{${ }^{238} \mathrm{U} /{ }^{206} \mathrm{~Pb}$} & \multirow{2}{*}{ Error } & \multicolumn{4}{|c|}{ Age } & \multirow{2}{*}{$\begin{array}{r}\text { Conc. } \\
(\%)\end{array}$} \\
\hline & & & & & & & & & & & & & & & ${ }^{206} \mathrm{~Pb} /{ }^{238} \mathrm{U}$ & Error & ${ }^{207} \mathrm{~Pb} /{ }^{206} \mathrm{~Pb}$ & Error & \\
\hline 1.1 & $\mathrm{e}, \mathrm{osc}, \mathrm{p} / \mathrm{rd}$ & 226 & 124 & 0.55 & 0.83 & 76 & 0.395 & 0.9 & 7.4 & 1.1 & 0.135 & 0.6 & 2.5 & 0.9 & 2145 & 17 & 2168 & 10 & 99 \\
\hline 2.1 & $e, o s c / h b, f$ & 28 & 26 & 0.93 & 0.45 & 8 & 0.321 & 1.7 & 4.9 & 2.6 & 0.11 & 1.9 & 3.1 & 1.7 & 1795 & 27 & 1805 & 35 & 99 \\
\hline 3.1 & $\mathrm{e}, \mathrm{osc} / \mathrm{hd}$, anh & 469 & 242 & 0.52 & 3.49 & 165 & 0.425 & 0.9 & 9.9 & 0.9 & 0.169 & 0.3 & 2.4 & 0.9 & 2285 & 16 & 2550 & 5 & 88 \\
\hline 4.1 & $\mathrm{e}, \mathrm{osc}, \mathrm{p} / \mathrm{fr}$ & 216 & 128 & 0.59 & 0.11 & 75 & 0.403 & 0.9 & 7.6 & 1 & 0.137 & 0.4 & 2.5 & 0.9 & 2183 & 17 & 2183 & 8 & 100 \\
\hline 5.1 & e, hd, anh & 464 & 216 & 0.47 & 0.24 & 160 & 0.4 & 1.1 & 7.5 & 1.2 & 0.136 & 0.4 & 2.5 & 1.1 & 2171 & 21 & 2173 & 8 & 100 \\
\hline 6.1 & $\mathrm{e}, \mathrm{osc}, \mathrm{rd}$ & 582 & 187 & 0.32 & 8.57 & 64 & 0.138 & 1 & 2.4 & 1.6 & 0.127 & 1.3 & 7.2 & 1 & 835 & 8 & 2052 & 23 & 37 \\
\hline 7.1 & $\mathrm{e}, \mathrm{osc}, \mathrm{fr} / \mathrm{rd}$ & 417 & 294 & 0.71 & 9.42 & 156 & 0.48 & 0.9 & 15.3 & 0.9 & 0.231 & 0.2 & 2.1 & 0.9 & 2526 & 18 & 3061 & 4 & 79 \\
\hline 8.1 & $\mathrm{e}, \mathrm{osc}, \mathrm{fr}$ & 440 & 257 & 0.58 & 6.88 & 71 & 0.201 & 1.5 & 3.6 & 1.6 & 0.129 & 0.5 & 5 & 1.5 & 1178 & 16 & 2090 & 10 & 52 \\
\hline 9.1 & $\mathrm{e}, \mathrm{osc}, \mathrm{fr} / \mathrm{rd}$ & 198 & 95 & 0.48 & 1.94 & 72 & 0.431 & 1 & 9.5 & 1.1 & 0.159 & 0.5 & 2.3 & 1 & 2311 & 19 & 2449 & 9 & 93 \\
\hline 10.1 & $\mathrm{e}, \mathrm{hd}$, anh & 1359 & 1867 & 1.37 & 3 & 279 & 0.244 & 2.1 & 3.6 & 2.4 & 0.106 & 1.1 & 4.1 & 2.1 & 1409 & 27 & 1737 & 19 & 79 \\
\hline 11.1 & $\mathrm{e}, \mathrm{osc} / \mathrm{hb}, \mathrm{fr}$ & 332 & 404 & 1.22 & 12.03 & 41 & 0.16 & 2.4 & 0.16 & 2.4 & 0.15 & 1.9 & 0.15 & 1.9 & 959 & 21 & 2343 & 32 & 37 \\
\hline 12.1 & $\mathrm{e}, \mathrm{osc}, \mathrm{p} / \mathrm{fr}$ & 306 & 814 & 2.66 & 13.73 & 44 & 0.189 & 2.2 & 0.189 & 2.2 & 0.173 & 1 & 0.173 & 1 & 1117 & 23 & 2583 & 16 & 38 \\
\hline 13.1 & $\mathrm{c}, \mathrm{osc}, \mathrm{p} / \mathrm{fr}$ & 173 & 110 & 0.64 & -1.33 & 81 & 0.537 & 1 & 0.537 & 1 & 0.185 & 0.4 & 0.185 & 0.4 & 2771 & 22 & 2698 & 6 & 103 \\
\hline 13.2 & $\mathrm{e}, \mathrm{osc}, \mathrm{p} / \mathrm{fr}$ & 471 & 226 & 0.48 & 8.68 & 119 & 0.321 & 1.8 & 7.6 & 2.3 & 0.171 & 1.5 & 3.1 & 1.8 & 1793 & 28 & 2572 & 25 & 65 \\
\hline 14.1 & e, osc/hd, ov & 371 & 342 & 0.92 & 0.2 & 127 & 0.397 & 1.4 & 7.3 & 1.5 & 0.133 & 0.6 & 2.5 & 1.4 & 2156 & 25 & 2138 & 10 & 101 \\
\hline 15.1 & $\mathrm{e}, \mathrm{osc} / \mathrm{hd}, \mathrm{p}$ & 516 & 188 & 0.36 & 6.26 & 133 & 0.319 & 1.3 & 6.9 & 1.4 & 0.156 & 0.6 & 3.1 & 1.3 & 1787 & 20 & 2415 & 10 & 70 \\
\hline 16.1 & $\mathrm{e}, \mathrm{osc}, \mathrm{eq} / \mathrm{fr}$ & 67 & 82 & 1.22 & 0.18 & 19 & 0.332 & 1.3 & 5.2 & 1.7 & 0.113 & 1.2 & 3 & 1.3 & 1849 & 20 & 1847 & 21 & 100 \\
\hline 17.1 & e, osc, zfr & 370 & 337 & 0.91 & 4.61 & 60 & 0.193 & 1.0 & 2.6 & 4.0 & 0.099 & 3.8 & 5.2 & 1.0 & 1136 & 10 & 1610 & 71 & 68 \\
\hline 18.1 & $\mathrm{e}, \mathrm{hb}, \mathrm{fr}$ & 87 & 102 & 1.18 & 9.93 & 17 & 0.228 & 2.3 & 3.1 & 10.9 & 0.098 & 10.7 & 4.4 & 2.3 & 1323 & 27 & 1594 & 200 & 81 \\
\hline
\end{tabular}

Site: $\mathrm{m}$, middle; e, end or egde.

Grain habit: p, prism; rd, round; ov, ovoide; eq, equant; fr, fragment; anh, anhedral.

CL petrography: osc, oscillatory zoning; hb, homogeneous bright; hd, homogeneous dark; sz, sector zoning; r, rim/overgrowth.

$\mathrm{Pb}(\%)$ and ${ }^{206} \mathrm{~Pb}(\mathrm{ppm})$, indicate the common and radiogenic portions, respectively. All errors are 1-sigma. 
Table $\mathbf{S}_{5}$. U-Pb isotopic data results for metarhyodacite sample CA39 of the Bairro dos Prestes Formation

\begin{tabular}{|c|c|c|c|c|c|c|c|c|c|c|c|c|c|c|c|c|c|c|c|}
\hline \multirow{2}{*}{ Spot } & \multirow{2}{*}{ Site } & \multirow{2}{*}{$\begin{array}{c}\mathrm{U} \\
(\mathrm{ppm})\end{array}$} & \multirow{2}{*}{$\begin{array}{c}\text { Th } \\
(\mathrm{ppm})\end{array}$} & \multirow{2}{*}{$\mathrm{Th} / \mathrm{U}$} & \multirow{2}{*}{$\begin{array}{l}{ }^{206} \mathrm{~Pb} \\
(\%)\end{array}$} & \multirow{2}{*}{$\begin{array}{l}{ }^{206} \mathrm{~Pb} \\
(\mathrm{ppm})\end{array}$} & \multirow{2}{*}{${ }^{206} \mathrm{~Pb} /{ }^{238} \mathrm{U}$} & \multirow{2}{*}{ Error } & \multirow{2}{*}{${ }^{207} \mathrm{~Pb} /{ }^{23 !} \smile$} & \multirow{2}{*}{ w. or } & \multirow{2}{*}{${ }^{207} \mathrm{~Pb} /{ }^{206} \mathrm{~Pb}$} & \multirow{2}{*}{ Error } & \multirow{2}{*}{${ }^{238} \mathrm{U} /{ }^{206} \mathrm{~Pb}$} & \multirow{2}{*}{ Error } & \multicolumn{4}{|c|}{ Age } & \multirow{2}{*}{$\begin{array}{c}\text { Conc. } \\
(\%)\end{array}$} \\
\hline & & & & & & & & & & & & & & & ${ }^{206} \mathrm{~Pb} /{ }^{238} \mathrm{U}$ & Error & ${ }^{207} \mathrm{~Pb} /{ }^{206} \mathrm{~Pb}$ & Error & \\
\hline 1.1 & $\mathrm{e}, \mathrm{osc} / \mathrm{hb}, \mathrm{p}$ & 50 & 30 & 0.60 & 0.75 & 13 & 0.314 & 1.4 & 4.7 & 2.2 & 0.108 & 1.8 & 3.2 & 1.4 & 1760 & 21 & 1759 & 32 & 100 \\
\hline 2.1 & $\mathrm{e}, \mathrm{osc}, \mathrm{p} / \mathrm{fr}$ & 54 & 37 & 0.69 & 0.74 & 14 & 0.307 & 1.3 & 4.6 & 1.9 & 0.109 & 1.4 & 3.3 & 1.3 & 1724 & 20 & 1776 & 25 & 97 \\
\hline 3.1 & $\mathrm{e}, \mathrm{osc}, \mathrm{p}$ & 70 & 50 & 0.71 & 0.21 & 19 & 0.318 & 1.2 & 4.8 & 1.7 & 0.109 & 1.1 & 3.1 & 1.2 & 1778 & 19 & 1780 & 20 & 100 \\
\hline 5.1 & $\mathrm{e}, \mathrm{osc}, \mathrm{p} / \mathrm{fr}$ & 60 & 38 & 0.63 & 1.74 & 16 & 0.309 & 2.3 & 4.7 & 5.3 & 0.11 & 4.8 & 3.2 & 2.3 & 1736 & 36 & 1798 & 87 & 96 \\
\hline 5.2 & n, osc/hd, p/fr & 608 & 220 & 0.36 & 1.03 & 146 & 0.282 & 0.8 & 4.1 & 0.9 & 0.106 & 0.3 & 3.5 & 0.8 & 1601 & 12 & 1737 & 6 & 91 \\
\hline 6.1 & $\mathrm{e}, \mathrm{osc}, \mathrm{p}$ & 118 & 96 & 0.82 & 1.26 & 30 & 0.297 & 1.1 & 4.4 & 1.8 & 0.107 & 1.4 & 3.4 & 1.1 & 1678 & 17 & 1756 & 26 & 95 \\
\hline 7.1 & $\mathrm{e}, \mathrm{osc} / \mathrm{hb}, \mathrm{eq}$ & 88 & 85 & 0.96 & 4.97 & 18 & 0.247 & 1.4 & 3.7 & 6.4 & 0.109 & 6.2 & 4.1 & 1.4 & 1422 & 18 & 1775 & 114 & 91 \\
\hline 8.1 & $\mathrm{e}, \mathrm{osc} / \mathrm{hb}, \mathrm{p} / \mathrm{rd}$ & 60 & 38 & 0.63 & 2.39 & 16 & 0.314 & 2.2 & 4.6 & 4.4 & 0.106 & 3.8 & 3.2 & 2.2 & 1759 & 34 & 1738 & 69 & 101 \\
\hline 9.1 & $\mathrm{e}, \mathrm{osc}, \mathrm{p} / \mathrm{fr}$ & 59 & 42 & 0.71 & 0.66 & 16 & 0.323 & 1.3 & 4.9 & 2.7 & 0.110 & 2.3 & 3.1 & 1.3 & 1805 & 21 & 1801 & 42 & 100 \\
\hline 10.1 & $\mathrm{~m}, \mathrm{osc}, \mathrm{p}$ & 68 & 47 & 0.69 & 0.51 & 18 & 0.314 & 1.2 & 4.7 & 1.7 & 0.109 & 1.2 & 3.2 & 1.2 & 1759 & 19 & 1789 & 22 & 98 \\
\hline 11.1 & $\mathrm{e}, \mathrm{osc} / \mathrm{hb}, \mathrm{p} / \mathrm{fr} / \mathrm{rd}$ & 44 & 29 & 0.66 & 0.92 & 12 & 0.311 & 1.4 & 4.6 & 3.2 & 0.106 & 2.9 & 3.2 & 1.4 & 1747 & 22 & 1736 & 53 & 101 \\
\hline
\end{tabular}

Site: $\mathrm{m}$, middle; $\mathrm{e}$, end or egde.

Grain habit: p, prism; rd, round; ov, ovoide; eq, equant; fr, fragment; anh, anhedral.

CL petrography: osc, oscillatory zoning; hb, homogeneous bright; hd, homogeneous dark; sz, sector zoning; r, rim/overgrowth

$\mathrm{Pb}(\%)$ and ${ }^{206} \mathrm{~Pb}(\mathrm{ppm})$, indicate the common and radiogenic portions, respectively. All errors are 1-sigma. 


\title{
CHAPTER 4
}

\section{Pure shear-dominated transpression in the southern Ribeira Belt, Brazil: finite strain and quartz c-axis fabric constraints from the Bairro dos Prestes Formation ${ }^{1}$}

\begin{abstract}
The Paleoproterozoic Bairro dos Prestes Formation and Apiaí Mirim Complex in the Ribeira Belt, SE Brazil, are good targets for the implementation of microstructural methods that help to understand their deformational evolution. Shape Preferred Orientation (SPO) and Lattice Preferred Orientation (LPO) techniques were performed in seven samples. The results show oblate shape for the finite strain ellipsoid with steep NE XY plane and high rake X-axis, correlate with the planar and linear structures measured in field. A transpressive regime with predominance of pure shear is compatible with such deformational pattern. The deformational temperature calculated from the opening angles (c-axis pattern fabric) vary from $531^{\circ} \mathrm{C}-593^{\circ} \mathrm{C}$ to $613^{\circ} \mathrm{C}-703^{\circ} \mathrm{C}$ with spatial variation in the study area from north (lowest) to south (highest), present correlation with temperature metamorphism and dynamic recrystallized mechanism. The c-axis structures display dependence on finite strain ellipsoid geometry, recrystallized grains size and transitions of dislocation glide systems. Water weakening and solution transfer process modify the c-axis structure geometry, increasing the opening angles, orienting the maxima at medium angles of the stretching lineation and activating of prism $<\mathrm{a}>$ slip.
\end{abstract}

Key words: Shape Preferred Orientation (SPO); Lattice Preferred Orientation (LPO); c-axis fabric; opening angle geothermometer; Ribeira Belt

${ }^{1}$ Forero-Ortega, A.J., Campanha, G.A.C., Faleiros F.M. 


\subsection{INTRODUCTION}

The fabric of deformed rocks can be represented by the orientation and strength of the shape preferred orientation (SPO) and lattice preferred orientation (LPO) of the mineral aggregate and it is related to the object shape, size and orientation, strain rate, temperature, fluids, as well the incremental and finite strain geometry. Under isotropic rheology the planar and linear fabrics shapes represent the XY plane and X-axis of finite strain ellipsoid, respectively (Passchier and Trouw, 2005). Therefore, the quantification and characterization of deformation shape are possible through the measurement of SPO and LPO microstructure fabrics of the rocks (Zucali et al., 2014).

The shape preferential orientation (SPO) allows to quantify the geometrical properties of deformed rocks through the image analysis of the shape, size and orientation of grain aggregate. Considering a homogeneous deformation and equidimensional initial shapes, the SPO can be related to the finite strain ellipsoid and the orientation of its main axes reflect the principal planar and linear deformational structures (Launeau and Robin, 2003, 2005; Passchier and Trouw, 2005).

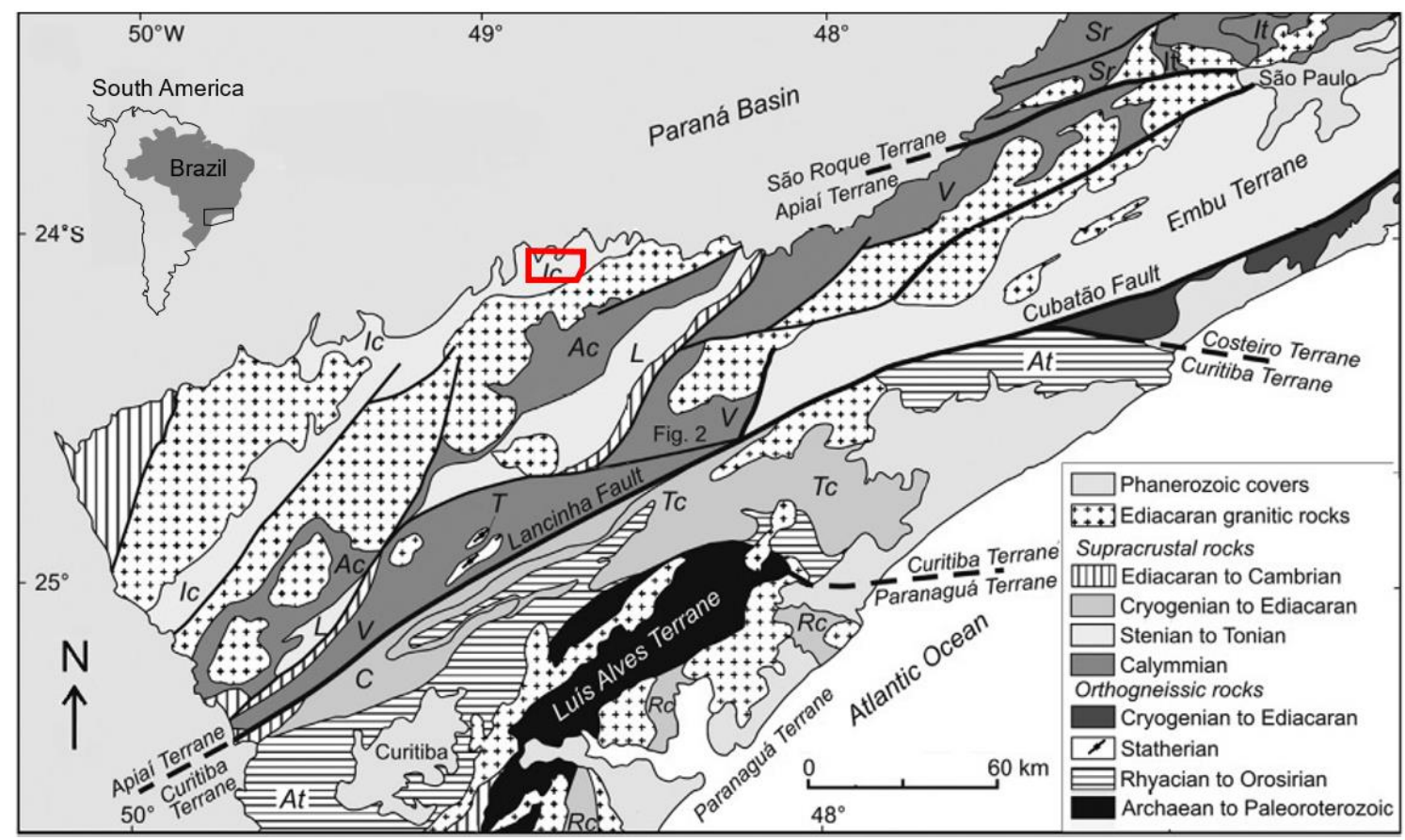

Figure 4. 1. Simplified geotectonic map of the Southern and central portions of the Ribeira Belt with location of study area Figure 4.2. (From Campanha et al., 2015).

Quartz grains plastically deformed exhibit microstructures and preferred crystallographic orientation developed from intracrystalline slip systems (in charge of accommodation of crystal plasticity) and geometry of the flow pattern (Passchier and Trouw, 2005). The c-axis LPO 
pattern generated give information about the progressive deformation flow, magnitude and symmetry of finite strain, kinematic framework, deformational temperature and strain rate regimes under they were develop (Schmid and Casey, 1986; Lister et al., 1978; Law, 1987, 1990; Faleiros et al., 2010).

From experimental and natural tests it was deduced that c-axis fabrics and their opening-angle are sensitive to different variables, as transition prism [c] to basal <a $>$ (Lister and Hobbs, 1980; Stipp et al., 2002a; Keller and Stipp, 2011), temperature (e.g. Faleiros, 2016; Law, 2014), pressure (Faleiros et al., 2010), grain size and mechanism of recrystallized (e.g. Tullis et al., 1973; Hobss 1968), mineral aggregates, lithological variation (Lister and Dornsiepen, 1982), deformation path (e.g. Lister and Hobbs, 1980; Law, 1990), water activity (solution and precipitation process) (Tullis et al., 1973; Hippert, 1994; Stallard and Shelley, 1995) and preexisting fabrics, all of them can modify the c-axis fabric.

The structural framework of Bairro dos Prestes Formation (before included in the Itaiacoca Group) (Forero et al., 2018) have been discussed by some authors and three (e.g. Soares, 1987b; Theodorovicz et al., 1988) or four deformational events (e.g. Takahashi et al., 1984; Souza, 1990; Reis Neto, 1994; Siga Jr et al., 2009) have been proposed. But none makes use of microstructural techniques for quantification and characterization of the microstructural fabric and the finite strain ellipsoid. We analyzed through image tools and software the shape preferred orientation (porphyroclasts) of four samples and the lattice preferred orientation (caxis of recrystallized quartz) of seven samples.

From the SPO analysis we determinate the geometry of ellipsoid strain and compared the plane $\mathrm{XY}$ and $\mathrm{X}$-axis calculated with the field data (foliation and lineation) collected. The LPO technique provides information about the deformation mechanisms, strain path and shape, and deformational temperature calculated from the opening-angle of the quartz c-axis fabric. These deformational temperatures are compared with the metamorphism temperature indicated by mineral assemblages of the metamorphic peak. We discuss the effects of the dynamic recrystallization, 3D strain type, basal <a> - prism [c] switch, water weakening and solution transfer process in the transition and geometry of c-axis pattern and the opening-angles. 


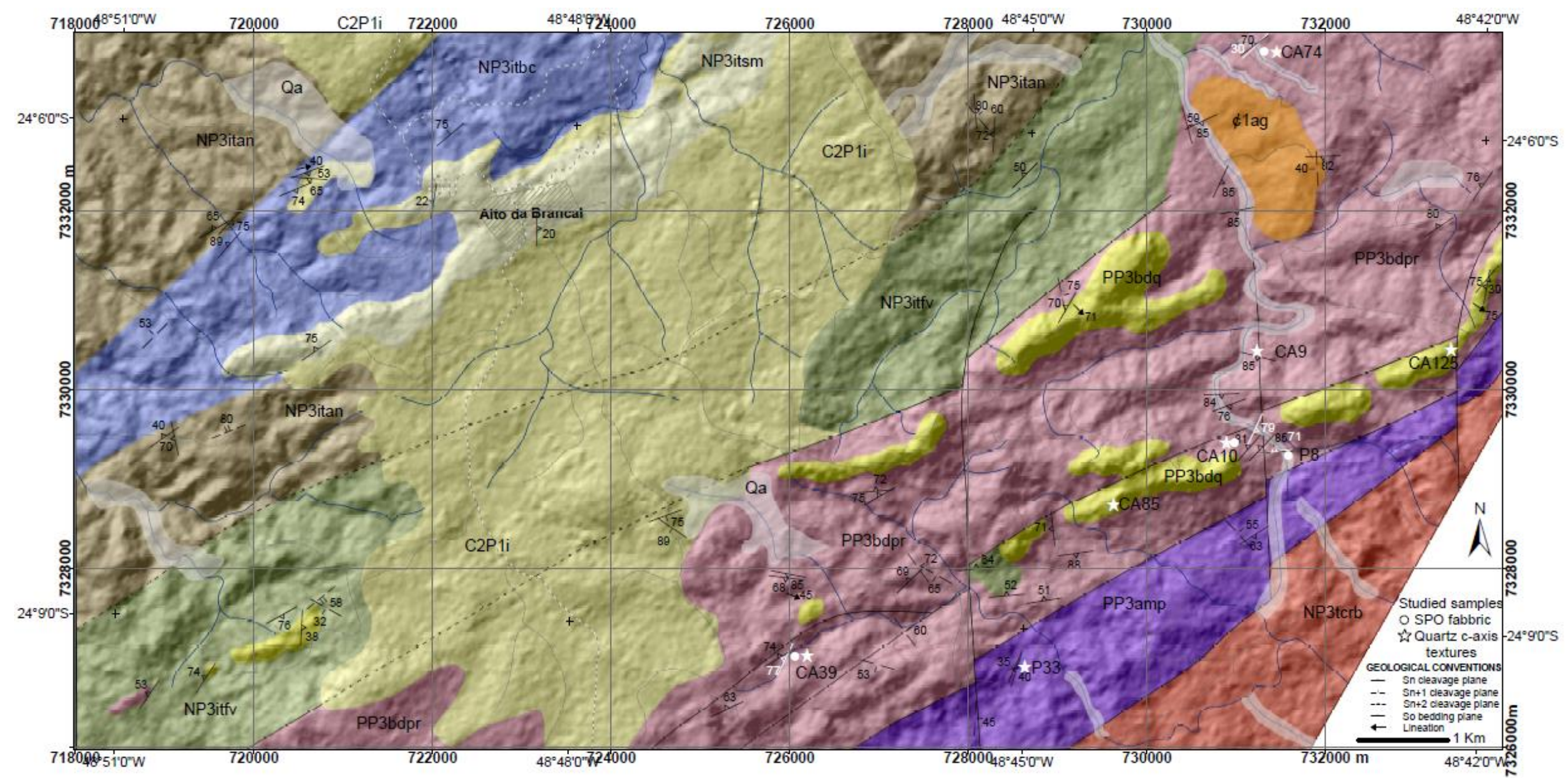

Figure 4. 2. Geological map of the studied area. Itararé Group (C2P1i), Apiaí-Guaçu metasandstone ( $₫ 1$ ag), Ribeirão Branco granite (NP3tcrb); Itaiacoca Group: Serra dos Macacos formation (NP 3itsm), Fazenda Velha Metabasic Suit (NP 3itfv), Água Nova Formation (NP3itan) and Bairro dos Campos Formation (NP3itbc), Bairro dos Prestes Formation: phyllite (MP1bdpr) with intercalations of quartzites (MP1bdq), and Apiaí Mirim Complex (PP3amp). (Taken from Forero-Ortega et al., 2018). Structural attitudes in black were measured in the field, and in white calculated by SPO. 


\subsection{GEOLOGICAL CONTEXT}

In the southwestern portion of the Neoproterozoic Ribeira Belt (Apiaí terrane), between Itapeva and Ribeirão Branco region (SP) (Figure 4.1), are present three main Proterozoic litostratigraphic units: the Itaiacoca Group, the Bairro dos Prestes Formation and the ApiaíMirim Complex (Figure 4.2), differentiated in ages and lithological associations (Forero-Ortega et al., 2018). The Itaiacoca Group (Almeida, 1944; Souza, 1990, 1992) is composed mainly by metapelites and phyllites (Água Nova Formation) with thin intercalations of metatuffs (Forero-Ortega et al., 2018) in transitional contact with calcitic and dolomitic metalimestones (Bairro dos Campos Formation) with Conophyton type stromatoliths (Almeida, 1944; Fairchild, 1977; Sallun Filho, 1999; Sallun Filho and Fairchild, 2000, 2004, 2005), massive quartzites (Serra dos Macacos Formation) and metabasites with geochemical characteristics of MORB, similar to the basaltic magmatism generated in back-arc basin, associated with metadolomites, quartzites, talc schists and chlorite schists (Fazenda Velha Metabasic Suit, Forero-Ortega et al., 2018).

The Bairro dos Prestes Formation exhibits metavolcanosedimentary rocks (phyllites sometimes with amygdaloid structures), quartzites, and restricted occurrences of metarhyodacite and metaconglomerate (Forero-Ortega et al., 2018). The metaconglomerate is constituted by pebbles of quartzite, volcanosedimentary rock and black phyllites supported by a metamudstone matrix. The Apiaí Mirim Complex is restricted to the southeast of the study area, in tectonic contact with the adjacent units and it is constituted by paragneiss and medium to coarse grained micaceous quartzite, under amphibolite metamorphic facies.

These units are affected by three deformational events, the first responsible for the development of principal foliation plane $\left(S_{n}\right)$, characterized as schistosity or slaty cleavage depending on the lithology, being penetrative in all units, sub-parallel to the compositional bands in metalimestones rocks and pelitic intercalations contacts, and with steep dips and NE-SW strikes (Figure 4.3a). The $S_{n}$ planes are deformed by $S_{n+1}$ and $S_{n+2}$ foliations, represented by crenulation cleavages present mainly in the metapelitic and metavolcanosedimentary rocks. The $\mathrm{S}_{\mathrm{n}+1}$ is associated with tight folds with NW axial-planes (Figure 4.3b) in quartzite, metavolcanosedimentary and pelitic sequence, and the $\mathrm{S}_{\mathrm{n}+2}$ with open folds with NE axialplanes (Figure 4.3c) in quartzite and phyllite. 


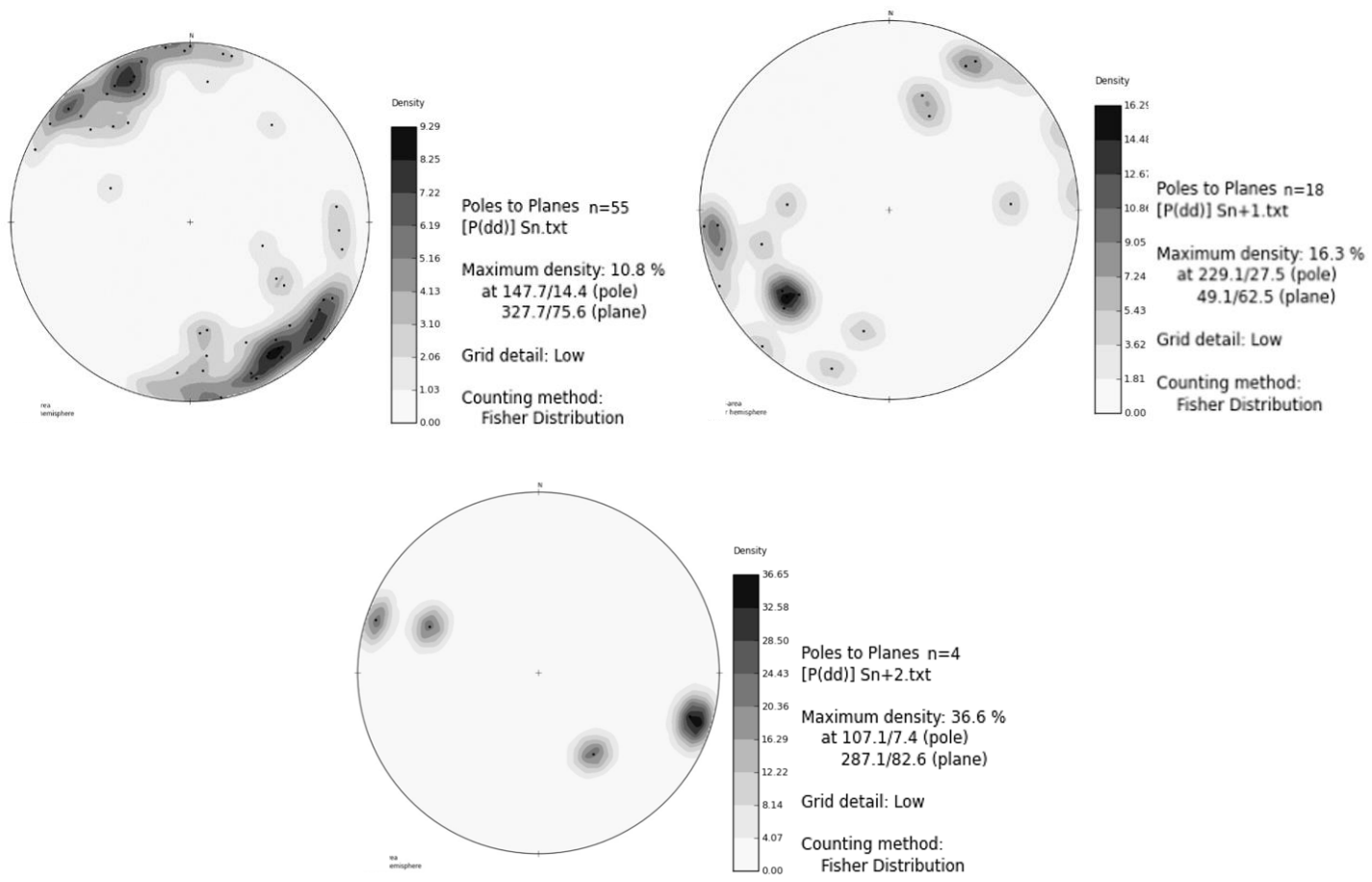

Figure 4. 3. Stereographic projection of the poles concentration of (a) $S_{n}$, (b) $S_{n+1}$ and (c) $S_{n+2}$ planes (Schmidt-Lambert projection lower hemisphere, mean plane in dip direction / dip).

Recent geochronological data suggest a Paleoproterozoic age $(1761 \pm 14 \mathrm{Ma})$ for the sedimentation of the Bairro dos Prestes Formation and Neoproterozoic age (613.5 $\pm 9.6 \mathrm{Ma}$ ) for the deposition of Itaiacoca Group (Forero-Ortega et al., 2018).

\subsection{PETROGRAPHY AND MICROSTRUCTURES}

Seven samples were analyzed under thin section for LPO (Table 4.1), one metarhyodacite (CA39.2) and five quartzites (CA9b, CA10c, CA74c, CA85, CA125) of Bairro dos Prestes Formation and one paragneiss (P33) of the Apiaí Mirim Complex. Three of these (CA10, CA39, CA74) and one metaconglomerate hand-sample were also analyzed for SPO.

Table 4. 1. Mineralogy, deformation mechanism (Subgrain rotation SGR, grain boundary migration GBM and pressure solution PS), opening angle of quartz c-axis structures and the calculated deformation temperature.

\begin{tabular}{|c|c|c|c|c|}
\hline Sample & Mineralogy & $\begin{array}{c}\text { Deformation } \\
\text { mechanism }\end{array}$ & $\mathrm{T}\left({ }^{\circ} \mathrm{C}\right)$ & $\begin{array}{c}\text { C-axis opening } \\
\text { angle }\end{array}$ \\
\hline CA9b & Qz, Mc, Pl, Tur, Bt, Ms, Zrn, Ap, Opq & SGR-GBM-PS & 593 & 79 \\
\hline CA10c & Qz, Fsp, Pl, Tur, Ms, Zrn, Ap, Opq & SGR-GBM-PS & 565 & 75 \\
\hline CA39.2 & Qz, Fsp, Pl, Bt, Ms, Zrn, Opq & GBM-PS & 655 & 88 \\
\hline CA74c & Qz, Pl, Tur, Bt, Ms, Zrn, Ap, Opq & GBM- PS & 613 & 82 \\
\hline CA85 & Qz, Zrn, Ap, Ms, Opq & SGR-GBM-PS & 531 & 70 \\
\hline CA125 & Qz, Fsp, Ms, Zrn, Opq & SGR-GBM-PS & 544 & 72 \\
\hline P33 & $\begin{array}{c}\text { Qz, Fsp, Mc, Pl, Ms, Fi, Bt, Zrn, Ap, Ep, } \\
\text { Cb, Opq }\end{array}$ & GBM & 703 & 95 \\
\hline
\end{tabular}


The paragneiss of the Apiaí-Mirim Complex, sample P33 (Figure 4.5k) is constitute by quartz + potassic feldspar + microcline + plagioclase + muscovite + fibrolite + biotite The potassic feldspar occurs as peritectic phase in the matrix (Figure 4.51) and as principal mineral in the leucosome (Figure 4.5m). The metamorphic association involved quartz, feldspar, microcline, plagioclase, fibrolite and biotite, and the muscovite is a retrometamorphic mineral (A12SiO5 + K-feldspar + liquid $=$ Muscovite + quartz) . The rock stability field is delimitated by reactions two and eight (Figure 4.4), implying an upper temperature limit of approximately $865^{\circ} \mathrm{C}$ (Spear et al., 1999), under amphibolite facies metamorphism.

The metarhyodacite sample has phenocrystals of feldspar with perthite and antiperthite textures, plagioclase, biotite, muscovite and quartz, and a microcrystalline matrix of chlorite, biotite, white micas and opaque minerals. The fine-grained matrix suggests greenschist facies metamorphism. But the quartz microcrystals in the strain shadows of phenocrystals present deformation mechanism of higher temperature (grain boundary migration), suggesting ranges upper than $500^{\circ} \mathrm{C}$.

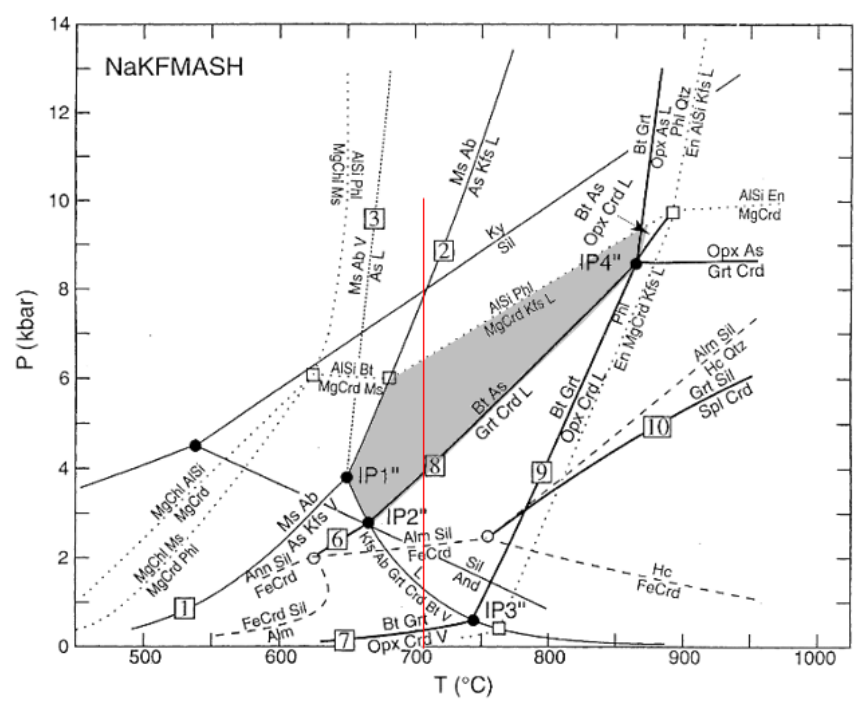

Figure 4. 4. P-T diagram for paragneiss sample with grey pentagon representing the stability field delimited by the reactions two and eight and red line corresponding to the deformation temperature calculated from quartz c-axis fabric opening-angles. Adapted from Spear et al. (1999).

The quartzites samples display a simple mineralogy, represented by $\mathrm{Pl}+\mathrm{Ms}+\mathrm{Qz} \pm \mathrm{Fsp} \pm \mathrm{Mc}$ $\pm \mathrm{Bt}$, being a bad temperature indicator, and some crystals can be detrital.

The intervenient phyllites and metavolcanosedimentary rocks of the Bairro dos Prestes Formation show a mineral assemblage of $(\mathrm{Ms}+\mathrm{Bt}+\mathrm{Qz})$ also compatible with greenschist facies metamorphism.

All samples present two deformation mechanisms, crystal-plastic deformation (dynamic recrystalization) and solution transfer. 
a.
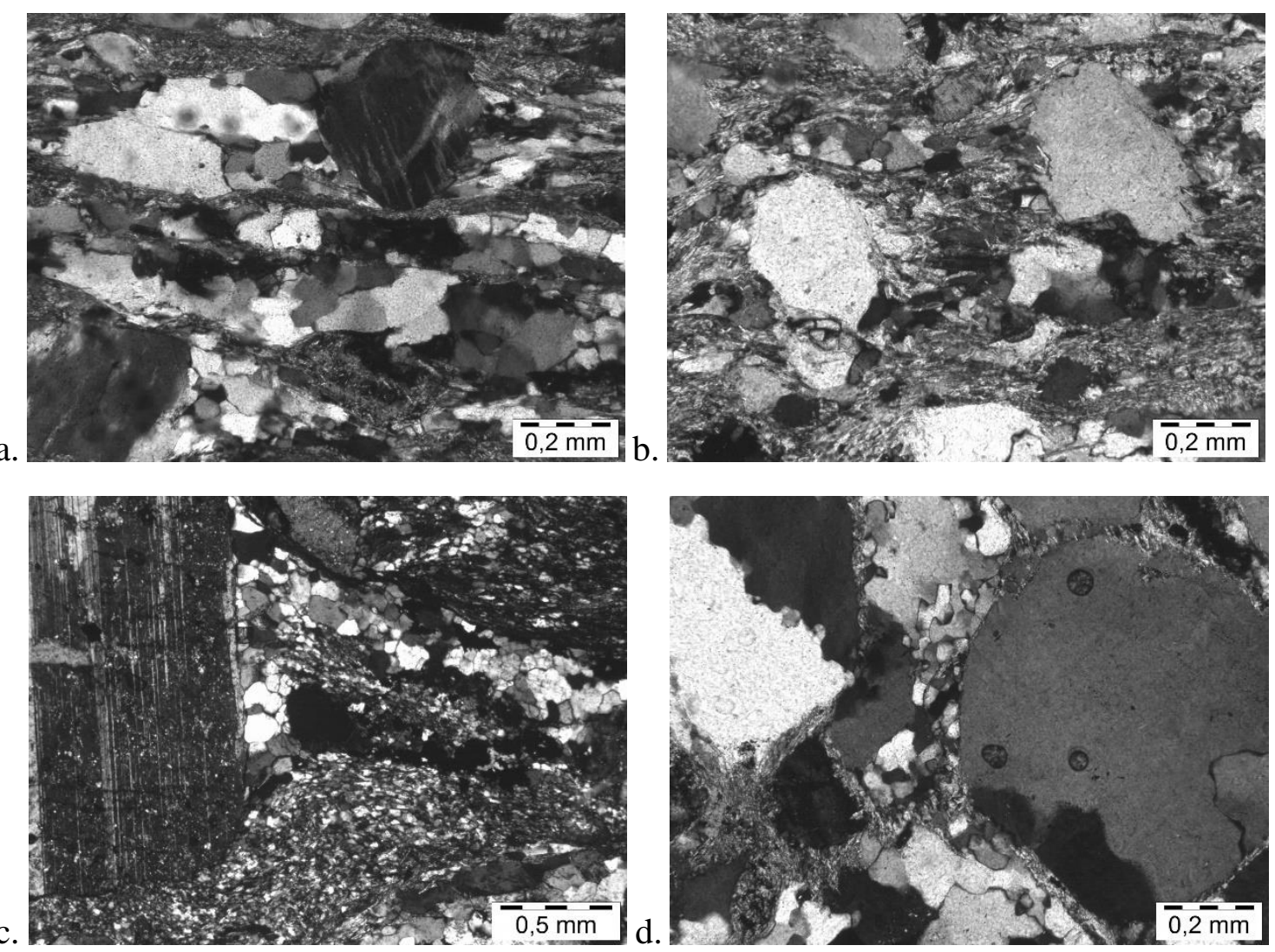

e.
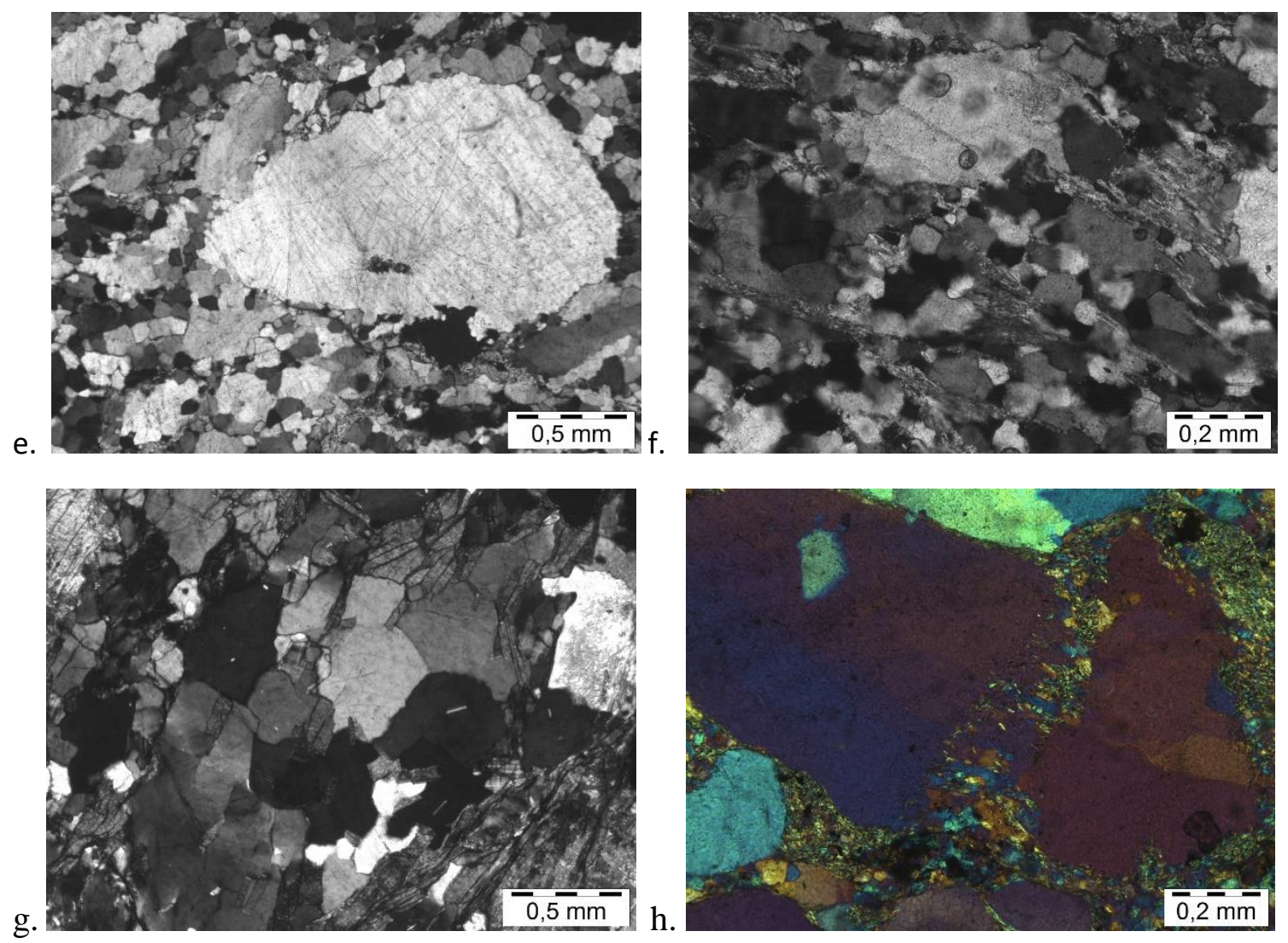

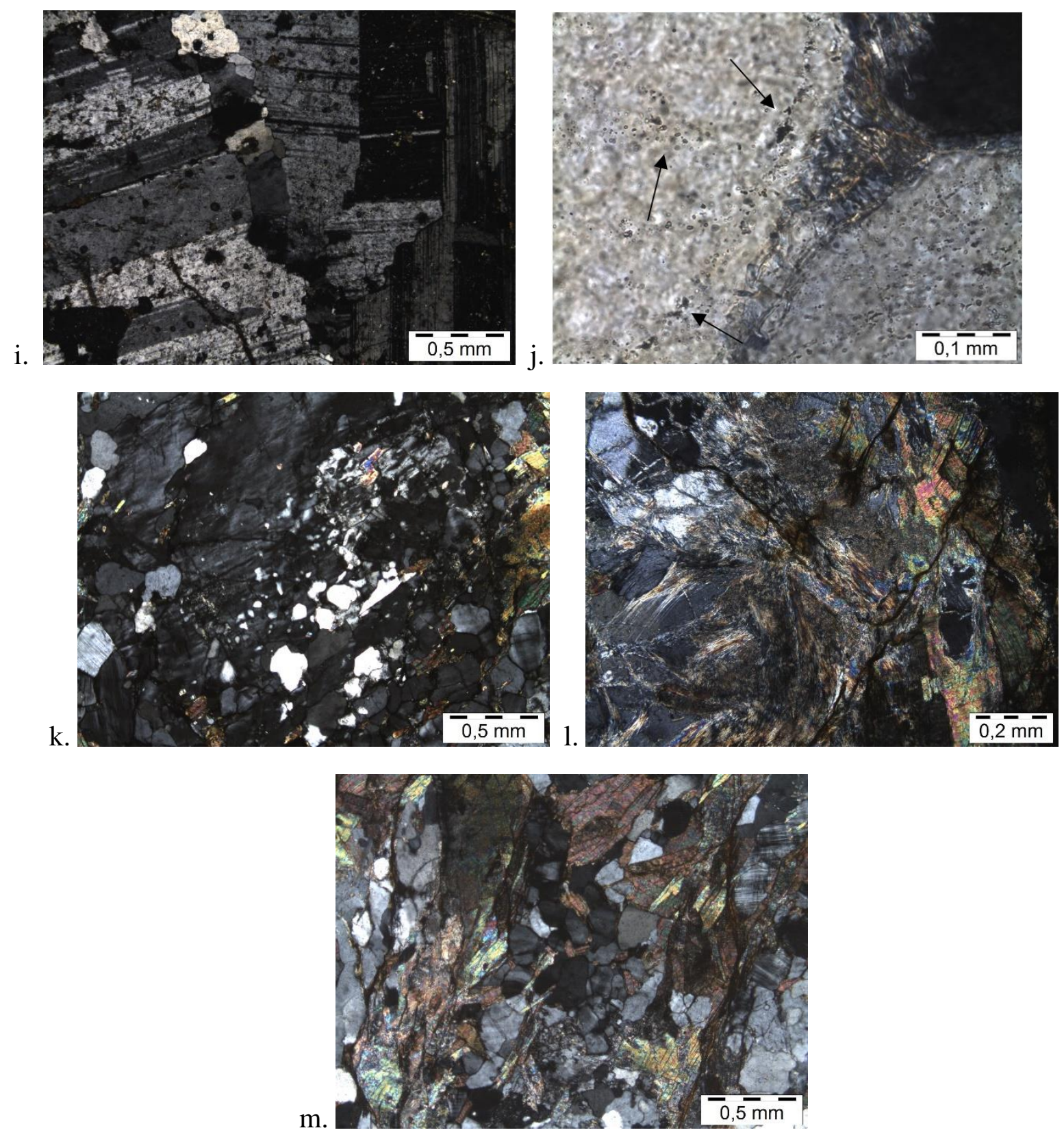

Figure 4. 5. Cross-polarized light optical photomicrographs of dynamic recrystallization mechanisms of quartz aggregates: (a) Sample CA09b: quartz and feldspar porphyroclasts with irregular and elongated shape alternating with fine matrix of sericite and quartz microcrystals. (b) Sample CA10c: quartz porphyroclasts with irregular shape and strain shadow of recrystallized quartz with lobate boundaries. (c) Sample CA39.2: plagioclase porphyroclasts with strain shadow of straight recrystallized quartz and fine matrix of mica and feldspar microcrystals. (d) Sample CA74c: quartz porphyroclasts with cuspate shape and boundaries with mica and lobate recrystallized material. (e) Sample CA85: quartz porphyroclasts with deformation lamellae and polygonal shapes of recrystallized quartz. (f) Sample CA125: quartz porphyroclasts with lobated boundaries and recrystallized quartz with pinning structure. (g) Sample P33: quartz porphyroclasts with straight boundaries and with pinning and window structures. (h) Cross polarized light optical photomicrographs under compensator plate showing optic continuity of the quartz porphyroclasts with ondulose extinction and recrystallized quartz. (i) Crosspolarized light optical photomicrographs of vein in the plagioclase porphyroclast filled with previously dissolved silica. (j) Inclusion trails parallel and perpendicular to quartz porphyroclast boundaries highlighting the host grain growth Photomicrography under cross polarized light of (k) paragneiss displaying (l) fibrolite and feldspar as peritectic minerals and (m) quartz, potassic feldspar and plagioclase constituting the leucosome fraction. 
The solution transfer process is evidenced by the presence of mica at porphyroclasts boundaries (Figure 4.d), optical continuity of the porphyroclasts and recrystallized material (Figure 4.5h), dissolved material deposited in intragranular veins (Figure 4.5i), and fluid inclusion trails (Figure 4.5j); these characteristics evidence the porphyroclasts growth and intracrystalline plastic deformation in water presence (Trepmann and Stöckhert, 2003). The samples (with exception of P33) generally display porphyroclasts with deformation lamellae, undulose extinction and $\sigma$ and $\delta$ sigmoids subparallel to $\mathrm{S}_{\mathrm{n}}$; and adjacent to the porphyroclasts are observed strain shadows and mantled porphyroclasts with fine-grained dynamically recrystallized quartz (Figure 4.5).

The dynamic recrystallization processes present in the samples are subgrain rotation (SGR) and grain boundary migration recrystallization (GBM). The SGR recrystallization generates weak ribbon-shape (slightly elongated) with high angles boundaries porphyroclasts (Figure 4.5a-b and d-f), while the subgrains with GBM microstructure (Figure 4.5a-h) present crystals with irregular and polygonal shapes (straight and lobate boundaries with triple junctions of approximately $120^{\circ}$ ) (Passchier and Trouw, 2005), and pinning structure of quartz grain boundaries on muscovite crystals or mica as inclusions (Figure $4.5 \mathrm{f}-\mathrm{g}$ ). The samples also show strain caps and strain shadows (Passchier and Trouw, 2005) with gradual transition between their fine-grained dynamically recrystallized grains and the matrix.

The conglomerate sample (P8) used for the SPO analysis is constituted by pebbles of quartzite, metavolcanosedimentary and black phyllites supported by a metapelitic matrix.

\subsection{SPO FABRIC}

Hand-sample cuts and thin sections were made along three non-paralell planes of four fieldoriented samples (metaconglomerate, metarhyodacite and two quartzites) with the purpose of determinate the Shape Preferred Orientation (SPO). Each sample was reoriented in the laboratory and the cuts orientation measured with a magnetic compass. The photomicrography of thin sections, as the hand-sample cuts digital photographies were digitalized in the CorelDraw $^{\mathrm{TM}}$ software for highlight the crystals boundaries, and they were subsequently converted into binary raster images (black and white). From the sectional raster images, strain ellipses (2D) with their respective long and short axes were deduced by the Inertia tensor method (Launeau and Cruden, 1998) in the SPO program (Launeau and Robin, 2003, 2005). 
The software allows to divide each image in subsets in order to make combinatory analyses between them.
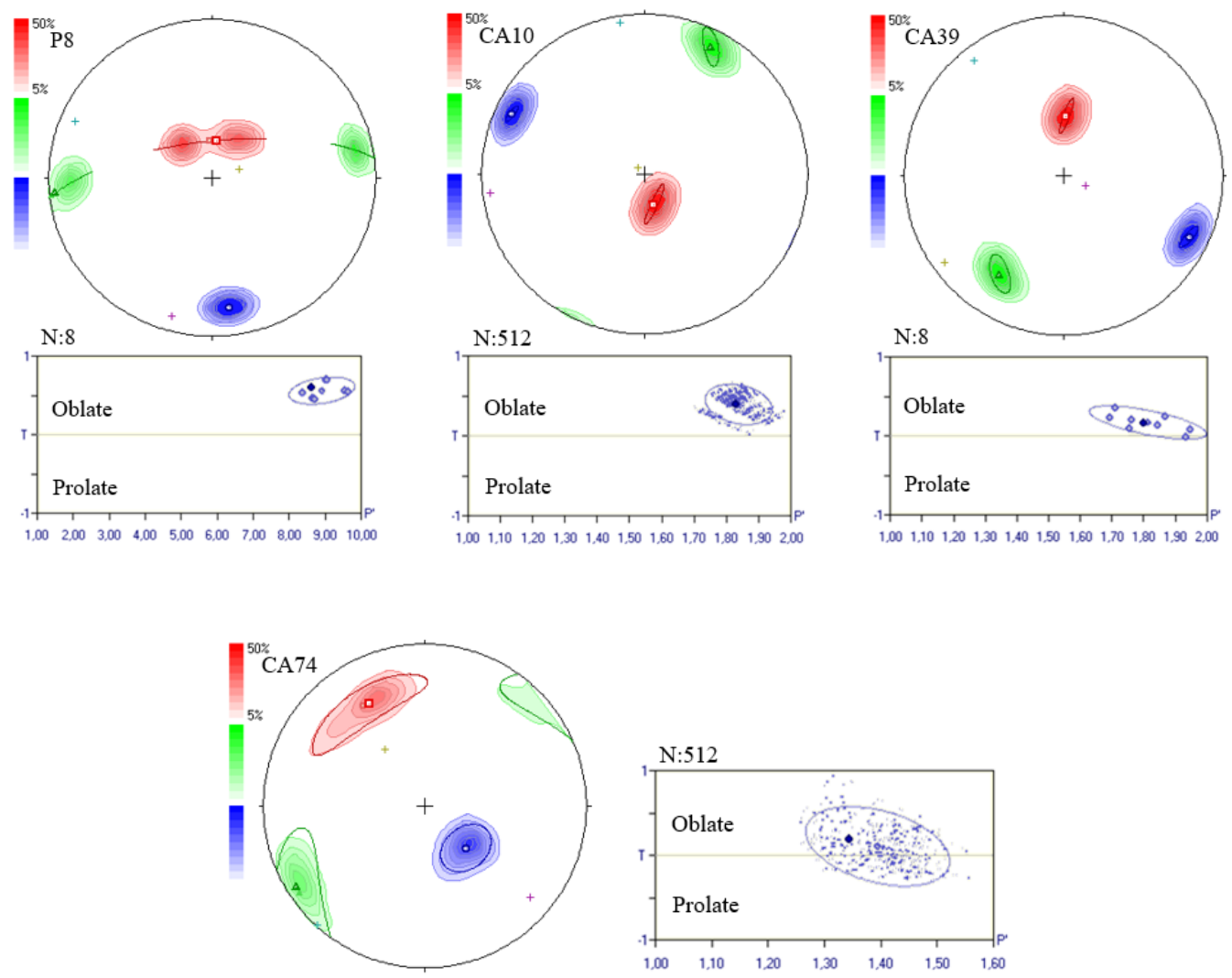

Figure 4. 6. Principal direction orientations of the strain ellipsoid $(X, Y$ and $Z$ axes in red, green and blue respectively) and shape parameters. Jelinek (1981) parameters are $\mathrm{P}^{\prime}=\exp \left[2\left(\left(\ln \frac{\mathrm{k}_{1}}{\mathrm{k}_{\text {mean }}}+\ln \frac{\mathrm{k}_{2}}{\mathrm{k}_{\text {mean }}}+\ln \frac{\mathrm{k}_{3}}{\mathrm{k}_{\text {mean }}}\right)\right)\right]^{1 / 2}, \mathrm{~T}=\left[2\left(\ln \mathrm{K}_{2}-\ln \mathrm{K}_{3}\right) /\left(\ln \mathrm{K}_{1}-\ln \mathrm{K}_{3}\right)\right]-1$, with $\mathrm{k}_{\text {mean }}=\frac{\mathrm{k}_{1}+\mathrm{k}_{2}+\mathrm{k}_{3}}{3}$. The $K_{1}$ axis represents the lineation while $K_{3}$ is the pole of the foliation (with principal axes $K_{1}>K_{2}>K_{3}$ ).

The calculated sectional subsets (ellipses) were integrated in the ELLIPSOID program (Launeau and Robin, 2003) to find the 3D 'bulk ellipsoid' (Figure 4.6), with the orientation of its principal axes $(\mathrm{X}, \mathrm{Y}, \mathrm{Z})$ and shape parameters. The program also calculates an 'incompatibility index' $(\sqrt{ } \mathrm{F} \%)$, which measures the compatibility or misfit between the sectional ellipses (2D) and the calculated 3D ellipsoid (Robin, 2002), and also establishes if the sectional ellipses lead to a 3D hyperboloid instead of an ellipsoid (Launeau and Robin, 2005). The fit is considered better if $\sqrt{F}<10 \%$ and it is ideal when values are $\sqrt{F}=0 \%$ (Launeau and Robin 2005). The ellipsoid shape can be described by the $\mathrm{T}$ parameter, when $\mathrm{T} \sim 0(\mathrm{X} / \mathrm{Y}=\mathrm{Y} / \mathrm{Z})$ the shape is planar-linear (plane strain), $\mathrm{T}<0,(\mathrm{X}>\mathrm{Y}=\mathrm{Z})$ it is linear or prolate and $\mathrm{T}>0(\mathrm{X}=\mathrm{Y}>\mathrm{Z})$ the shape is planar or oblate. The anisotropy intensity can be represented by the $\mathrm{X} / \mathrm{Z}$ ratio or the anisotropy degree parameter, $\mathrm{P}^{\prime}$, which range from 1 upwards (sphere to ellipsoid; 1 to $\infty$ ) 
(Ramsay and Huber, 1983; Borradaile and Werner, 1994; Lagroix and Borradaile, 2000; Nakamura and Borradaile, 2004).

The calculated ellipsoids (table 4.2) are quite well defined, present their principal directions with dispersion cones with half-angles of standard deviation $(\sigma 1$ and $\sigma 2)<29^{\circ}$ and "incompatibility index" $(\sqrt{F})<10 \%$, the shape is planar (oblate; Figure 4.6-7), and they also exhibit $\mathrm{Z}$ axes (foliation poles) in the center of the density contours (area of maximum density), indicating that the mineral distribution is homogeneous and the foliation is the best-defined fabric element (Salazar, 2010; Archanjo et al., 2012). The XY planes have predominantly NESW strike with steep dips and the X-directions have predominantly high rakes (down-dip) coincident with the regional trend measured in field (Figure 4.2).

Table 4. 2. Strain ellipsoids obtained by the inertia tensor method. Orientation data of plane XY and main axes in strike and dip (right-hand rule), $\mathrm{X} / \mathrm{Z}$ maximum deformation, $\mathrm{T}$ shape and $\mathrm{K}$ style of strain parameter (with $\mathrm{K}=\frac{(\mathrm{X} / \mathrm{Y}-1)}{(\mathrm{Y} / \mathrm{Z}-1)}$ ), and $\sqrt{\mathrm{F}} \%$ incompatibility index.

\begin{tabular}{|c|c|c|c|c|c|c|c|c|c|c|c|}
\hline \multirow{2}{*}{ Sample } & \multirow{2}{*}{$\begin{array}{c}\text { Plane } \\
\text { XY }\end{array}$} & \multicolumn{3}{|c|}{$\begin{array}{l}\text { Values of the main } \\
\text { axes }\end{array}$} & \multicolumn{3}{|c|}{$\begin{array}{l}\text { Attitudes of the main } \\
\text { axes }\end{array}$} & \multirow[t]{2}{*}{$\mathrm{X} / \mathrm{Z}$} & \multirow[t]{2}{*}{$\mathrm{T}$} & \multirow[t]{2}{*}{$\mathrm{K}$} & \multirow[t]{2}{*}{$\sqrt{\mathrm{F}} \%$} \\
\hline & & $\mathrm{X}$ & $\mathrm{Y}$ & $\mathrm{Z}$ & $\mathrm{X}$ & $\mathrm{Y}$ & $\mathrm{Z}$ & & & & \\
\hline P8 Metaconglomerate & $263 / 71$ & 2.801 & 1.925 & 0.407 & $006 / 71$ & $264 / 04$ & $173 / 19$ & 6.88 & 0.611 & 0.122 & 2.1 \\
\hline CA10 Quartzite & $025 / 79$ & 0.046 & 0.037 & 0.025 & $163 / 73$ & $027 / 12$ & $295 / 11$ & 1.79 & 0.402 & 0.507 & 9.4 \\
\hline $\begin{array}{c}\text { CA39 } \\
\text { Metarhyodacite }\end{array}$ & $206 / 77$ & 0.292 & 0.230 & 0.163 & $002 / 60$ & $213 / 27$ & $116 / 13$ & 1.78 & 0.175 & 0.667 & 5.6 \\
\hline CA74 Quartzite & $226 / 30$ & 0.096 & 0.085 & 0.071 & $331 / 29$ & $237 / 06$ & $136 / 60$ & 1.34 & 0.193 & 0.656 & 6.5 \\
\hline
\end{tabular}

The ratio between the long and short axes or SPO anisotropy of the calculated ellipsoids for the samples CA10, CA39 and CA74 present very low $(\mathrm{X} / \mathrm{Z}<1.5)$ to low $(\mathrm{X} / \mathrm{Z}<2.0)$ values, while the P8 metaconglomerate is highly deformed $(\mathrm{X} / \mathrm{Z} \sim 7)$.

\subsection{QUARTZ C-AXIS FABRIC}

Quartz c-axis orientation were measured (approximately 300 grains in each sample) for recrystallized crystals of seven samples through a universal stage; the samples faces were cut perpendicular to foliation and parallel to stretching lineation, in order to compare our results with the fabric simulations that were presented in a projection plane containing the $\mathrm{XZ}$ finite strain section (Law, 1990). The quartz c-axes were represented by isofrequence curves in lower-hemisphere equal-area projections (Schmidt-Lambert net), in which the reference is the main finite strain axis (X, Y, Z) with the XY plane (foliation) in the EW vertical position and 
the X-axis (lineation) in the EW horizontal position of the net (Turner and Weiss, 1963; Wahlstrom, 1969; Santoro, 1998; Passchier and Trouw, 2005), using the Stereo32 program version 1.0.3 (Röller and Trepmann, 2011).

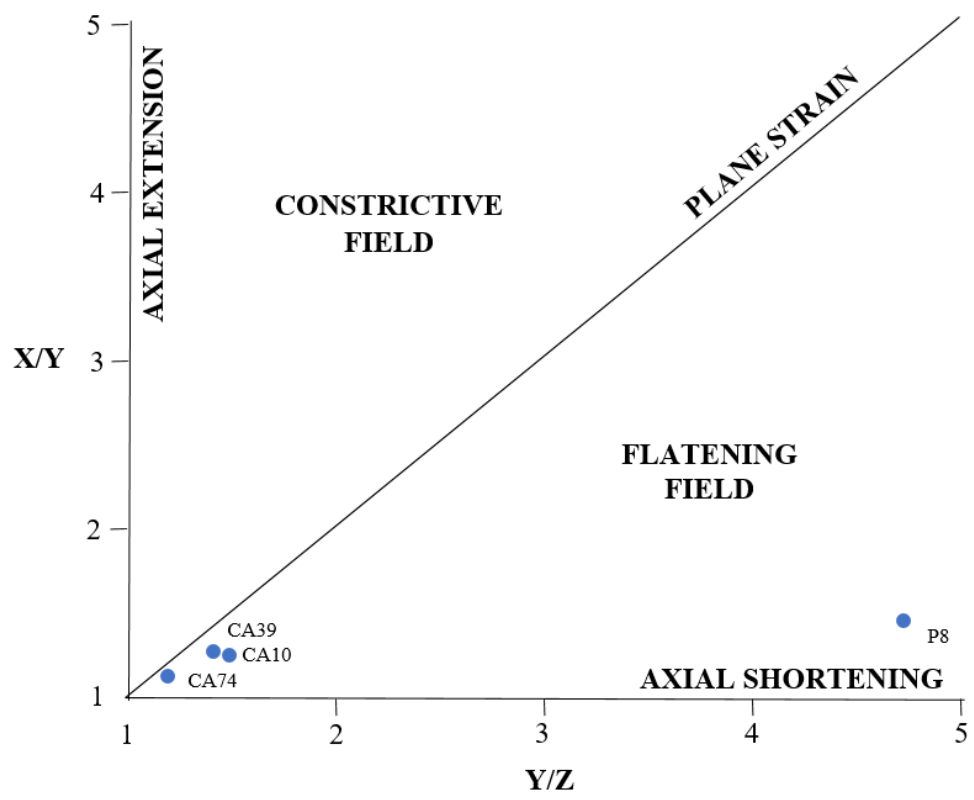

Figure 4. 7. Flinn diagram with the $X, Y, Z$ axes of the strain ellipsoid determinate by SPO analysis.

The patterns can be cross or single girdles, which are also symmetrical or asymmetrical with respect to finite strain axes indicating coaxial and non-coaxial deformation, respectively. The fabric skeletons asymmetry is used to deduce the sense of shear (Law, 1987, 1990). The c-axis fabric pattern can also define the dominate slip systems in quartz crystals development during the deformational event (e.g, Lister et al., 1978; Lister and Hobbs, 1980).

\subsubsection{Quartzc-axis patterns}

With exception of the quartzite CA85, the recrystallized grains c-axis isofrequence curves of the samples present type I crossed girdles (Lister, 1977) with two maxima slightly asymmetrically arranged in intermediate positions between $\mathrm{Z}$ and $\mathrm{X}$ at the pole figure periphery. The CA85 sample does not display c-axis fabric pattern well defined but display a c-axis maximum around $\mathrm{Z}$ and other at small angles to the stretching lineation and near to $\mathrm{Y}$, this pattern is similar to the structures developed in constrictive field (Lister and Hobbs, 1980). 

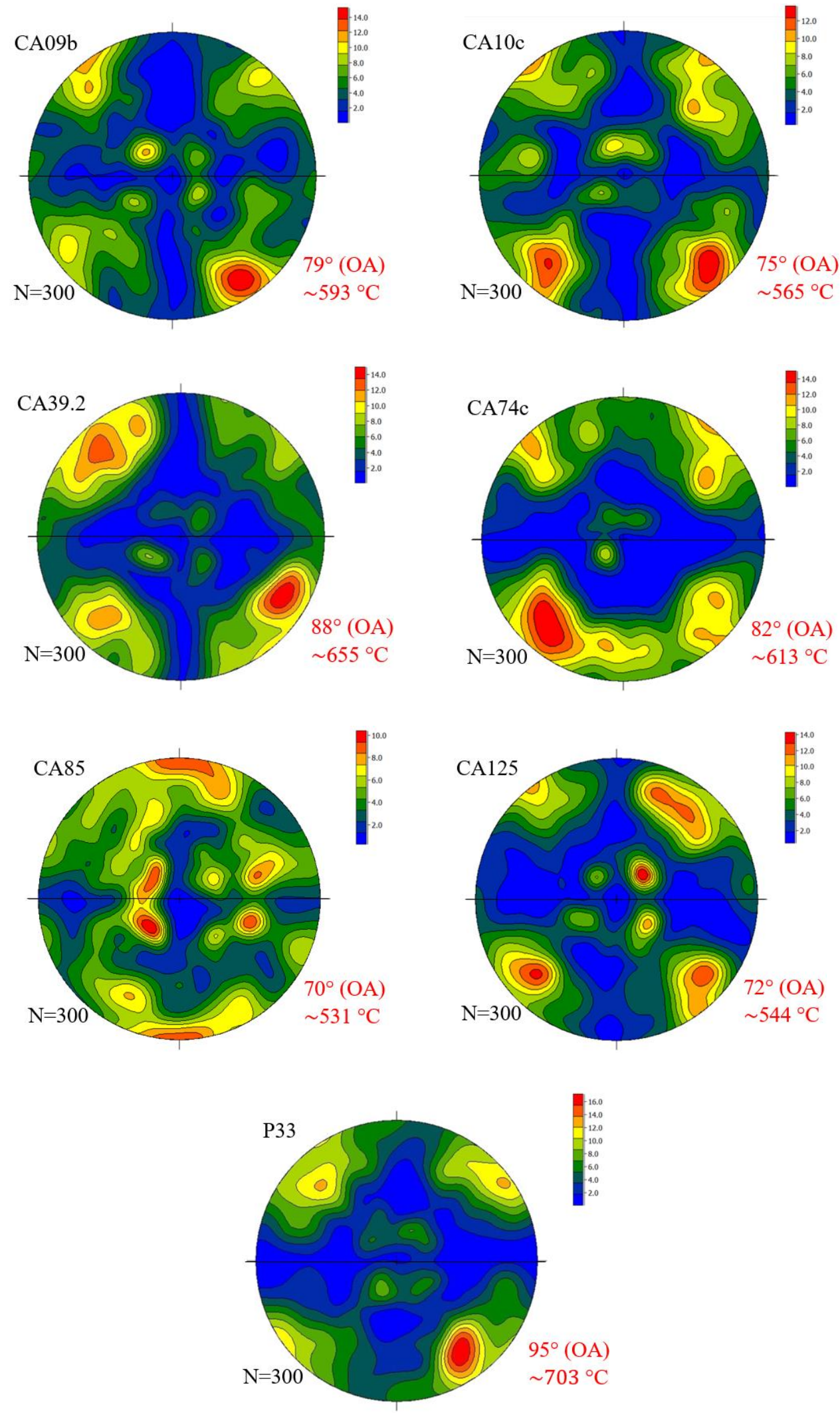

Figure 4. 8. Lower hemisphere equal-area projections of optically measured quartz c-axis fabrics; foliation oriented left-right and vertical and stretching lineation horizontal; it is also presented the opening-angles $(\mathrm{OA})$ and the respective calculated deformation temperatures. 


\subsubsection{Opening angle thermometer}

The opening angle $(\mathrm{OA})$ of the quartz c-axis fabric has been used as deformation thermometer since the fabrics were "locked in" during dislocation creep and dynamic recrystallization (e.g. Okudaira et al., 1998; Kruhl and Peternell, 2002; Law 2014; Faleiros et al., 2016) Its opening angle is directly related to the increase of temperature, hydrolytic weakening, decreasing strain rate (e.g. Lister and Dornsiepen, 1982; Kruhl, 1998; Law et al., 2013; Law 2014) and also show pressure-dependence (Faleiros et al. 2016).

The deformation temperature (Figure 4.6, Table 4.1) deduced from $\mathrm{OA}$ equation (for $250^{\circ} \mathrm{C} \leq \mathrm{T}$ $\leq 650^{\circ} \mathrm{C}$ and $\mathrm{OA} \leq 87^{\circ}$ conditions, Faleiros et al., 2016) yielded results ranging from $531{ }^{\circ} \mathrm{C}$ $593^{\circ} \mathrm{C}$ to $613^{\circ} \mathrm{C}-703^{\circ} \mathrm{C}$, at or above the greenschist-amphibolite facies limit, discordant with the temperatures indicated by the metamorphic mineral assemblages of the samples, that suggested greenschist facies. Law (2014), proposed that the water weakening can be the responsible for the higher deformation temperatures calculated by fabric opening-angles.

\subsection{DISCUSSION}

\subsubsection{Analysis of finite strain}

The lithologies of the Bairro dos Prestes Formation present different structures and deformation styles related with their rheological response and rock competence. The quartzite metarhyodacite and paragneiss display a relatively more rigid behavior, while the phyllites and metavolcanosedimentary show a more ductile deformation, exhibiting $\mathrm{S}_{\mathrm{n}+1}$ crenulation planes and tight folds. Comparing quantitatively our shape preferential orientation results (strain ratios $\mathrm{X} / \mathrm{Z}$ ranging from 1.34 to 1.79 , with 6.88 as anomalous value corresponding to the metaconglomerate sample) with the strain ratio obtained by Sallun Filho et al. (2005) measured in Conophyton type stromatoliths with conic shape (values between 1.37 and 1.91), it is possible to establish that despite the lithological differences, a relatively homogeneous strain ratio (with low values of finite deformation) is observed in the study area.

A X/Z ratio strain of 5.46 for metaconglomerate sample was determined subsequently through the Rf/Phi Strain Analysis Program Version 1 (Mulchrone and Lisle, 1999), based on Rf/ $\Phi$ technique (Ramsay, 1967; Ramsay and Huber, 1987), which assumed originally elliptical objects without preferred initial orientation. The result is not very different from the measured 
by the SPO technique $(X / Z=6.88)$. The lithology (quartzite, phyllites and metavolcanosedimentary pebbles supported by a metamudstone matrix) is probably responsible for the higher deformation ratio that this rock suffered.

\subsubsection{C-axis fabric transitions}

As mentioned above, the quartz c-axis fabric geometry, the opening angle (OA) and the calculated deformation temperature are sensitive to factors as the 3D strain type, strain rate, water weakening, dynamic recrystallization mechanisms, some of these will discussed below. 4.6.2.1 Mineralogy variation and impurities

The fabric transitions and dislocation glide system that operate during intracrystalline ductile deformation change with the rheological response (mineralogy difference and penetrative anisotropy differences) (Lister and Dornsiepen, 1982), they are also influenced by the flow stress and impurities present during the deformation process (Passchier and Throw,1996). In the obtained results (Figure 4.5 and 8), the CA9b, CA10c, CA39,2, CA74 and P33 samples with larger mineralogical variety and impurities in the matrix as mica grains, present higher deformation temperatures calculated from AO.

\subsubsection{Deformation pattern}

The quartz c-axis fabric pattern varies as strain is accumulated coaxially or non-coaxially, for this reason is used to indicate the deformation pattern to which it was subjected (Law 1990; Lister and Hobbs, 1980). The obtained quartz c-axis fabrics with exception of CA85 sample show an orthorhombic symmetry and crossed girdles geometry suggesting coaxial deformation and flattening-like strain shape, while the CA85 sample with c-axis maximum around $\mathrm{Z}$ and other at small angles to $\mathrm{Y}$ is similar to the fabrics development in constrictive field (Lister and Hobbs, 1980). The quartz c-axis opening angle decreasing is related with this variation, the lowest OA is present in the CA85 sample and higher OA are observed in the samples with type I crossed girdles.

4 6.2.3 Deformation temperature and their indirect relation in the basal <a $>$ - prism [c] switch

The relationship between quartz c-axis fabrics and opening angles of the samples match with the results deduced in natural and experimental tests (e.g. Hobbs, 1968; Tullis, 1971; Blacic, 1975; Lister, 1981; Lister and Dornsiepen, 1982; Schmid and Casey, 1986; Okudaira et al., 
1995; Kruhl, 1996; Morgan and law, 2004; Toy et al., 2008; Faleiros et al., 2016), in which is indicated that deformation temperature is an important factor in fabric transitions.

In our samples with SGR and GBM recrystallization is possible to see combination of multiple slip systems (basal <a>, rhomb $<\mathrm{a}>$ and prism $<\mathrm{a}>$ ), with some maxima concentrations towards Y pole, similar with the c-axis structures observed in the SGR to GBM transition by Stipp et al. (2002a) and Keller and Stipp (2011). They deduced that with the rising temperature, the onset of recrystallization can be influenced in the fabric patterns development, indicating a correlation between dynamic recrystallization mechanism and dislocation creep in the c-axis geometry texture (Urai et al., 1986; Schmid, 1994; Stipp et al., 2002a).

\subsubsection{Water weakening}

The effect of water in the $\mathrm{OA}$ is still ambiguous and its interpretation from experimental demonstration has been difficult (Paterson and Kekulawala, 1979 in Lister and Dornsiepen, 1982), however Blacic (1975) found from synthetic quartz experiments, that the prism <c> slip is developed at low temperature and it is favored over basal slip by increasing the temperature for low stress intensity regimes, since the water promote dislocations mobility and reduce the stress for glide resulting in larger fabric opening-angles (Griggs and Blacic, 1965; Den Brok, 1992; Lister et al., 1978; Muto, 2011). The transition between the three dislocation creep regimes and c-axis fabric geometry with high $\mathrm{OA}$ is also favored by the water weakening (Blacic, 1975; Den Brok and Spiers, 1991; Garbutt and Teyssier, 1991; Hirth and Tullis, 1992; Law, 2014).

Our samples with subgrain rotation recrystallization present deformation temperatures between $531^{\circ} \mathrm{C}$ to $593^{\circ} \mathrm{C}$ (Table 4.1 ), coinciding with the SGR-GMB transition estimated $570^{\circ} \mathrm{C}$ (Zulauf, 2001), however, the metamorphic assemble suggest lower temperate conditions, this effect can be related with the water activity in the dynamic recrystallization transition and consequently with the variation in the c-axes structures obtained.

\subsubsection{Solution transfer process}

In our samples the accommodation of strain was operate by solution transfer and crystal-plastic deformation processes (being dominant the last one), that implying water saturated conditions. Some structures that evidence the recrystallization and dissolution as concurrent process are porphyroclasts with undulating outline and recrystallized grains forming strain shadows (Figure 4.5a-b). Solution transfer operate mainly along the foliation surfaces favoured by the mica content, while the crystal-plastic deformation occurs as recrystallized tails ( $\sigma$ and $\delta$ sigmoids) 
or intramicrolithon deformation mechanism (mica-free parts), where the dissolution is difficult and recovery and recrystallization happened (Hippertt, 1994).

The samples CA09b, CA10c and CA125 (all with mica content less than or equal to 25\%) have deformation temperature on or higher to the estimated SGR-GMB transition temperature (Zulauf, 2001; Stipp et al., 2002a; Passchier and Trouw, 2005; Faleiros et al., 2010), their fabrics geometry (type I crossed girdles with two points c-axis) can be influence by incipient dissolution transfer process and intracrystalline plasticity (dislocation creep). As was also observed by Hippertt (1994), the grains with incipient dissolution show fabric pattern with caxis maxima at low angles to the stretching lineation, while the quartz grains formed from precipitation of material dissolved with partial intracrystalline plasticity deformation display caxes concentration in the center of the plot suggesting prism $<a>$ slip, and the grains with micapoor ribbon present c-axes structures with maxima around the foliation pole reflecting dislocation creep deformation.

\subsection{CONCLUSIONS}

The shape preferred orientation of the porphyroclast developed subvertical planes predominantly NE-SW strike with steep dips and main axis elongation with NW-SE trend and high rakes, with oblate (flattening) shapes, compatible with the regional trend measured in field, while the c-axis fabric of recrystallized quartz grains display cross girdles with preferred orientation at medium angles between $\mathrm{Z}$ and $\mathrm{X}$ (basal $<\mathrm{a}>$ and prism $<\mathrm{a}>\mathrm{slip}$ ) compatible with flattening fabric shape.

The predominantly oblate strain shape obtained by the SPO technique ( $\mathrm{T}$ ranging from 0.175 to 0.611 ) compatible with the observed c-axis fabric, together with the high rake of the strain $\mathrm{X}$-axis (lineation) and steep dip of the XY plane (foliation), suggest a transpressive regime with predominance of pure shear.

The deformation temperature obtained by the c-axis fabric opening angle ranges from $531^{\circ} \mathrm{C}$ $593^{\circ} \mathrm{C}$ to $613^{\circ} \mathrm{C}-703^{\circ} \mathrm{C}$ compatible with the variation from SGR and GBM to GBM regimes, but above the greenschist facies deduced from the metamorphic mineral assemblage.

The water weakening and solution transfer processes also modify the crystallization mechanism transition, the c-axis patterns (tends to develop maxima at low angles to stretching lineation and activated prism <a> slip) and the deformation temperature of the CA09b, CA10c and CA125 samples, because the solution transfer process increase the opening-angles of the c-axis fabric 
and subsequently the calculated temperature, that would be higher that the temperatures indicated by the mineral assemblage.

The samples present a relationship between the texture patterns (slip systems), dynamic recrystallization and deformation temperature with spatial variation. From North to South, the deformation temperature increases and the deformation mechanism vary from SGR and GBM to GBM. 


\section{CHAPTER 5}

\section{New occurrence of a Late Ediacaran metasandstone deposit located on the Apiaí-Guaçu river banks, southeast from Itapeva $(\mathrm{SP})^{1}$}

A.J. Forero-Ortega ${ }^{a}$, G.A.C. Campanha ${ }^{\text {a }}$, F.M. Faleiros ${ }^{\text {a }}$

A new occurrence of Late Ediacaran metasediments was found on the eastern bank of the ApiaíGuaçu river, approximately $20 \mathrm{~km}$ southeast from the Itapeva city, South of São Paulo state (Appendix 2). The unit has approximately $2 \mathrm{~km}^{2}$ of areal extension and it was recognized during the $\mathrm{c}$ 1:25.000 geological mapping and U-Pb geochronological study of the region.

The metasediments are composed of fine to coarse-grained feldspathic quartz metasandstone intercalated with small beds of metamudstone. Slaty cleavage planes (N88 $\left.{ }^{\circ} / 85^{\circ} \mathrm{SE}\right)$ were developed obliquely to the relic bedding $\left(\mathrm{S} 13^{\circ} \mathrm{E} / 54^{\circ} \mathrm{SW}\right)$.

The contact between the metasandstone layers and the adjacent rocks of the Statherian Bairro dos Prestes Formation (Forero et al., 2018) was inferred as discordant due the different lithological and structural associations, metamorphic degree and age.

Detrital zircon grains were concentrated from a metasandstone sample, according with the procedure established in the Geochronology Research Center of the University of São Paulo (CPGeo-USP). The grains were analyzed by U-Pb method using a NEPTUNE inductively coupled plasma-mass spectrometer (ICP-MS) and an excimer laser ablation (LA) system. The external zircon morphology (Figure 5.2) includes subrounded fragments and subhedral grains with ovoid habit typically of detrital sedimentary grains (Corfu, 2003). They mostly have inherited core and oscillatory composition zoning. From the 36 analyzed zircon grains, 26 yielded reliable ages with less than $10 \%$ discordance and low common $\mathrm{Pb}(<5 \%)$ (Table $\left.\mathrm{S}_{6}\right)$. The sample display a dominance of Neoproterozoic detrital ages (88\%) 588 Ma with $\mathrm{Th} / \mathrm{U}<$ 0.1 , suggesting that the grains were derived from metamorphic sources. Only $12 \%$ of the population show Paleoproterozoic and Neoarchean peaks with a ranging from 2000 to $2200 \mathrm{Ma}$ and 2550-2750 Ma interval, respectively. The youngest predominant grain group presents a U$\mathrm{Pb}$ Concordia age of 588.4 $\pm 1.8 \mathrm{Ma}$ with MSWD of 2.3 (Figure 5.1).

The lithological, structural and geochronological characteristics of the Apiaí-Guaçu metasandstone allows to correlate it with the molasse or transition stage basins of the Brasiliano 
Cycle, especially with the terrigenous type, as the Camarinha, Quatis, Iporanga, Pouso Alegre, Eleutério, Pico do Itapeva formations (Almeida, 1969; Campanha and Sadowski, 1969; Teixeira and Petri, 1993; Riccomini, 1993b; Teixeira, 1995; Moro, 2000; Teixeira and Petri, 2001; Teixeira et al., 2004; Campanha et al., 2008). A correlated near deposit is the Samambaia Conglomerate in the Guapiara region (Petri and Suguiu, 1969). The wide prevalence of the 588.4 $\pm 1.8 \mathrm{Ma}$ age detrital zircons group over the others and its metamorphic primary origin strongly suggest that the main source for the deposit was the Brasiliano collisional orogen. The Turvo-Cajati Formation, situated less than $80 \mathrm{~km}$ from the studied area and with regional collisional metamorphic peak in $589 \pm 12 \mathrm{Ma}$ (Faleiros et al., 2011) could be a good candidate for source area of sedimentation.

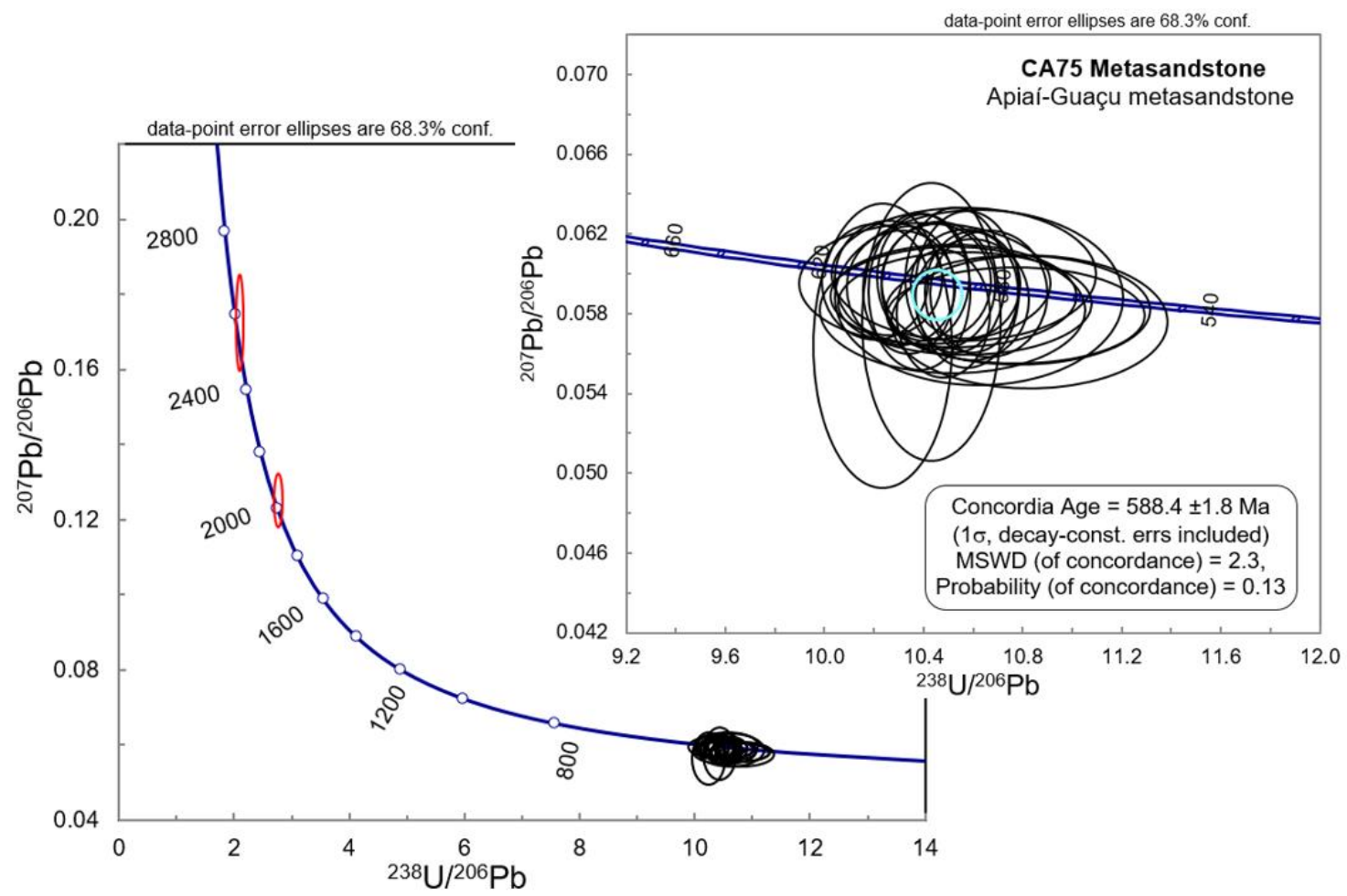

Figure 5. 1. Concordia diagram of ${ }^{206} \mathrm{~Pb} /{ }^{238} \mathrm{U}$ versus ${ }^{207} \mathrm{~Pb} /{ }^{235} \mathrm{~Pb}$ of CA75 metasandstone. 


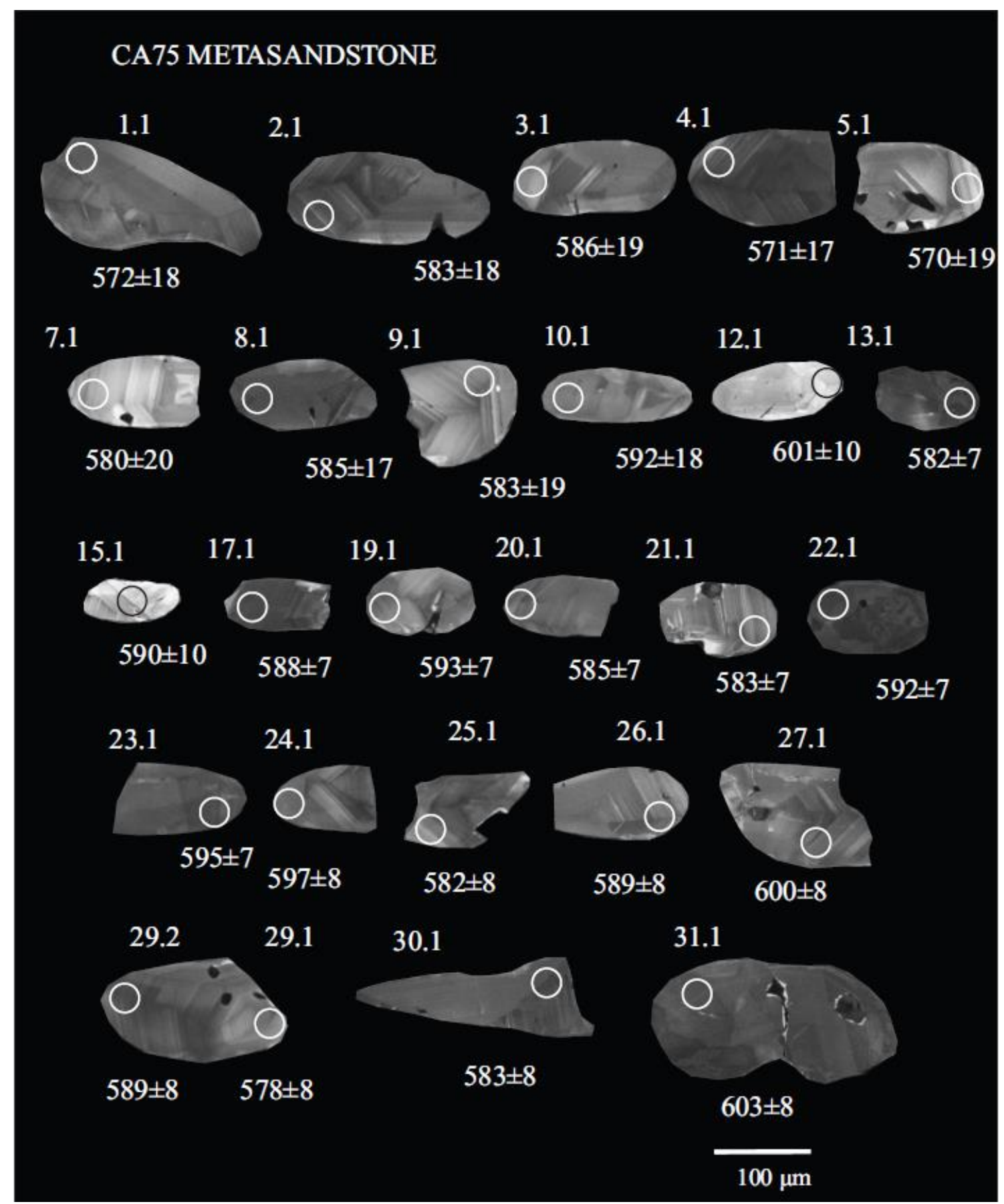

Figure 5. 2. CL images of zircon crystals from metasandstone - CA75. 
Table $\mathbf{S}_{6}$. Analytical LA-ICP-MS results for metasandstone CA75 of the Apiaí-Guaçu metasandstone.

\begin{tabular}{|c|c|c|c|c|c|c|c|c|c|c|c|c|c|c|c|c|c|c|c|}
\hline \multirow{2}{*}{ Spot } & \multirow{2}{*}{ Site } & \multirow{2}{*}{$\begin{array}{c}\mathrm{U} \\
(\mathrm{ppm})\end{array}$} & \multirow{2}{*}{$\begin{array}{c}\text { Th } \\
\text { (ppm) }\end{array}$} & \multirow{2}{*}{$\mathrm{Th} / \mathrm{U}$} & \multirow{2}{*}{$\begin{array}{c}{ }^{206} \mathrm{~Pb} \\
(\%)\end{array}$} & \multirow{2}{*}{$\begin{array}{l}{ }^{206} \mathrm{~Pb} \\
(\mathrm{ppm})\end{array}$} & \multirow{2}{*}{${ }^{206} \mathrm{~Pb} /{ }^{238} \mathrm{U}$} & \multirow{2}{*}{ Error } & \multirow{2}{*}{${ }^{207} \mathrm{~Pb} /{ }^{235} \mathrm{U}$} & \multirow{2}{*}{ Error } & \multirow{2}{*}{${ }^{207} \mathrm{~Pb} /{ }^{206} \mathrm{~Pb}$} & \multirow{2}{*}{ Error } & \multirow{2}{*}{${ }^{238} \mathrm{U} /{ }^{206} \mathrm{~Pb}$} & \multirow{2}{*}{ Error } & \multicolumn{4}{|c|}{ Age } & \multirow{2}{*}{$\begin{array}{r}\text { Conc. } \\
(\%)\end{array}$} \\
\hline & & & & & & & & & & & & & & & ${ }^{206} \mathrm{~Pb} /{ }^{238} \mathrm{U}$ & Error & ${ }^{207} \mathrm{~Pb} /{ }^{206} \mathrm{~Pb}$ & Error & \\
\hline 1.1 & $\mathrm{e}, \mathrm{hd}, \mathrm{fr} / \mathrm{rd}$ & 784 & 55 & 0.07 & 0.52 & 90.6 & 0.0928 & 0.003 & 0.745 & 0.033 & 0.0582 & 0.0018 & 10.7798 & 0.3524 & 572 & 18 & 539 & 65 & 101 \\
\hline 2.1 & $\mathrm{e}, \mathrm{osc}, \mathrm{fr} / \mathrm{p} / \mathrm{rd}$ & 867 & 43 & 0.05 & 1.07 & 101.3 & 0.0946 & 0.003 & 0.7627 & 0.0327 & 0.0585 & 0.0017 & 10.5671 & 0.3369 & 583 & 18 & 547 & 62 & 101 \\
\hline 3.1 & e, osc, ov & 390 & - & - & 0.77 & 44.8 & 0.0951 & 0.0032 & 0.7637 & 0.0367 & 0.0582 & 0.0021 & 10.515 & 0.3532 & 586 & 19 & 539 & 79 & 101 \\
\hline 4.1 & $\mathrm{e}, \mathrm{osc}, \mathrm{fr} / \mathrm{p} / \mathrm{rd}$ & 1016 & 55 & 0.05 & 0.44 & 117.8 & 0.0928 & 0.003 & 0.7416 & 0.0314 & 0.0579 & 0.0016 & 10.7724 & 0.3427 & 572 & 17 & 528 & 60 & 101 \\
\hline 5.1 & $\mathrm{e}, \mathrm{sz}, \mathrm{fr} / \mathrm{p} / \mathrm{rd}$ & 395 & - & - & 0.83 & 45.0 & 0.0924 & 0.0031 & 0.7337 & 0.0363 & 0.0576 & 0.0022 & 10.8272 & 0.3672 & 570 & 19 & 515 & 83 & 101 \\
\hline 7.1 & $\mathrm{e}, \mathrm{osc}, \mathrm{fr} / \mathrm{p} / \mathrm{rd}$ & 260 & 20 & 0.08 & 1.38 & 30.4 & 0.0941 & 0.0034 & 0.7633 & 0.0437 & 0.0588 & 0.0029 & 10.6245 & 0.3832 & 580 & 20 & 560 & 108 & 100 \\
\hline 8.1 & e, hd, ov & 924 & 36 & 0.04 & 0.52 & 108.5 & 0.095 & 0.003 & 0.7721 & 0.0316 & 0.0589 & 0.0017 & 10.5217 & 0.3274 & 585 & 17 & 564 & 60 & 100 \\
\hline 9.1 & $\mathrm{e}, \mathrm{osc}, \mathrm{fr} / \mathrm{rd}$ & 403 & 24 & 0.06 & 0.53 & 45.0 & 0.0947 & 0.0032 & 0.783 & 0.0378 & 0.06 & 0.0022 & 10.563 & 0.3529 & 583 & 19 & 603 & 83 & 99 \\
\hline 10.1 & $\mathrm{e}, \mathrm{hd}, \mathrm{ov}$ & 509 & 53 & 0.10 & 1.15 & 59.3 & 0.0961 & 0.0031 & 0.7883 & 0.0355 & 0.0595 & 0.002 & 10.4036 & 0.3355 & 592 & 18 & 585 & 78 & 100 \\
\hline 12.1 & $\mathrm{e}, \mathrm{hb}, \mathrm{ov}$ & 136 & 11 & 0.08 & 4.92 & 16.7 & 0.0977 & 0.0018 & 0.7598 & 0.0588 & 0.0564 & 0.0047 & 10.2339 & 0.1856 & 601 & 10 & 468 & 195 & 104 \\
\hline 13.1 & $\mathrm{e}, \mathrm{hd}, \mathrm{fr} / \mathrm{anh}$ & 1316 & 118 & 0.09 & 2.25 & 187.6 & 0.0944 & 0.0011 & 0.7685 & 0.0269 & 0.0591 & 0.002 & 10.5941 & 0.1238 & 582 & 7 & 569 & 73 & 100 \\
\hline 15.1 & $\mathrm{c}, \mathrm{osc} / \mathrm{hb}, \mathrm{fr} / \mathrm{rd}$ & 165 & 4 & 0.03 & 2.89 & 20.6 & 0.0959 & 0.0017 & 0.7611 & 0.0574 & 0.0576 & 0.0046 & 10.431 & 0.1855 & 590 & 10 & 514 & 176 & 102 \\
\hline 17.1 & $\mathrm{e}, \mathrm{hd}, \mathrm{fr} / \mathrm{rd}$ & 850 & 42 & 0.05 & 0.78 & 103.8 & 0.0954 & 0.0011 & 0.7627 & 0.028 & 0.058 & 0.0021 & 10.4801 & 0.1244 & 588 & 7 & 529 & 78 & 102 \\
\hline 19.1 & $\mathrm{e}, \mathrm{osc}, \mathrm{ov}$ & 367 & 45 & 0.12 & 0.70 & 45.3 & 0.0963 & 0.0013 & 0.7842 & 0.0345 & 0.0591 & 0.0026 & 10.3833 & 0.1359 & 593 & 7 & 569 & 98 & 100 \\
\hline 20.1 & $\mathrm{e}, \mathrm{osc}, \mathrm{fr} / \mathrm{p} / \mathrm{rd}$ & 519 & 33 & 0.06 & 0.25 & 63.2 & 0.095 & 0.0012 & 0.7825 & 0.0319 & 0.0597 & 0.0024 & 10.5261 & 0.1335 & 585 & 7 & 594 & 87 & 99 \\
\hline 21.1 & $\mathrm{e}, \mathrm{osc}, \mathrm{fr} / \mathrm{p} / \mathrm{rd}$ & 460 & 58 & 0.13 & 1.46 & 54.8 & 0.0946 & 0.0012 & 0.7724 & 0.034 & 0.0592 & 0.0026 & 10.5749 & 0.139 & 583 & 7 & 576 & 97 & 100 \\
\hline 22.1 & $\mathrm{e}, \mathrm{hd}, \mathrm{ov}$ & 1120 & 79 & 0.07 & 0.33 & 133.1 & 0.0962 & 0.0011 & 0.7934 & 0.028 & 0.0598 & 0.0021 & 10.3988 & 0.123 & 592 & 7 & 598 & 76 & 99 \\
\hline 23.1 & $\mathrm{e}, \mathrm{sz}, \mathrm{fr} / \mathrm{ov}$ & 951 & 57 & 0.06 & 0.49 & 111.9 & 0.0967 & 0.0011 & 0.7892 & 0.0283 & 0.0592 & 0.0021 & 10.3396 & 0.1217 & 595 & 7 & 574 & 76 & 100 \\
\hline 24.1 & $\mathrm{e}, \mathrm{hd}, \mathrm{fr} / \mathrm{p} / \mathrm{ov}$ & 755 & 65 & 0.09 & 0.79 & 86.8 & 0.097 & 0.0014 & 0.7932 & 0.0239 & 0.0593 & 0.0019 & 10.3096 & 0.1438 & 597 & 8 & 578 & 69 & 100 \\
\hline 25.1 & $\mathrm{e}, \mathrm{sz}, \mathrm{fr} / \mathrm{anh}$ & 539 & 25 & 0.05 & 0.24 & 59.9 & 0.0944 & 0.0014 & 0.7635 & 0.025 & 0.0587 & 0.002 & 10.5943 & 0.1524 & 582 & 8 & 555 & 75 & 100 \\
\hline
\end{tabular}




\begin{tabular}{rlccccccccccccccccccc}
26.1 & e, osc, fr/p/rd & 503 & 24 & 0.05 & 0.23 & 59.3 & 0.0956 & 0.0014 & 0.7825 & 0.0256 & 0.0594 & 0.0021 & 10.4589 & 0.1508 & 589 & 8 & 580 & 76 & 100 \\
27.1 & e, sz, fr/anh/rd & 793 & 73 & 0.09 & 0.31 & 94.6 & 0.0975 & 0.0014 & 0.8035 & 0.0243 & 0.0598 & 0.0019 & 10.258 & 0.1424 & 600 & 8 & 596 & 69 & 100 \\
29.1 & c, ic, fr/rd & 466 & 49 & 0.11 & 0.31 & 56.5 & 0.0938 & 0.0014 & 0.7635 & 0.0259 & 0.059 & 0.0021 & 10.6614 & 0.1563 & 578 & 8 & 568 & 79 & 100 \\
29.2 & e, osc, fr/rd & 913 & 131 & 0.14 & 0.25 & 111.8 & 0.0957 & 0.0013 & 0.7866 & 0.0238 & 0.0596 & 0.0019 & 10.4502 & 0.1453 & 589 & 8 & 590 & 69 & 99 & \\
30.1 & e, osc, fr/anh & 976 & 74 & 0.08 & 0.36 & 116.9 & 0.0946 & 0.0013 & 0.7758 & 0.0223 & 0.0595 & 0.0018 & 10.5683 & 0.1449 & 583 & 8 & 584 & 66 & 99 \\
31.1 & e, hd, anh & 824 & 38 & 0.05 & 0.06 & 94.7 & 0.098 & 0.0014 & 0.8055 & 0.0237 & 0.0596 & 0.0019 & 10.2038 & 0.1416 & 603 & 8 & 590 & 69 & 100 \\
\hline
\end{tabular}

Site: $\mathrm{m}$, middle; e, end or egde.

Grain habit: p, prism; rd, round; ov, ovoide; eq, equant; fr, fragment; anh, anhedral.

CL petrography: osc, oscillatory zoning; hb, homogeneous bright; hd, homogeneous dark; sz, sector zoning; r, rim/overgrowth.

$\mathrm{Pb}(\%)$ and ${ }^{206} \mathrm{~Pb}(\mathrm{ppm})$, indicate the common and radiogenic portions, respectively. All errors are 1-sigma. 


\section{CHAPTER 6}

\section{CONCLUSIONS}

In the 1:25,000 Geologic Map performed between Itapeva and Ribeirão Branco region (SP) eleven lithostratigraphic units were identified: Quaternary alluvial deposits, Jurassic-Cretaceous diabase dykes, the Carboniferous-Permian Itararé Group, the Late Ediacaran Apiaí-Guaçu metasandstone, the Neoproterozoic Ribeirão Grande Granite, three formations (Serra dos Macacos, Água Nova, Bairro dos Campos) and one magmatic suite (Fazenda Velha Metabasic Suite ) from the Neoproterozoic Itaiacoca Group, the Statherian Bairro dos Prestes Formation and Apiaí Mirim Complex. The Proterozoic units were affected by three folding phases and by NE-SE and NNE-SSW to NNW-SSE strike-slip faults.

Neoproterozoic ages were obtained from zircons grains of metabasites (571 $\pm 25 \mathrm{Ma}$ ) and metatuff (613 $\pm 10 \mathrm{Ma}$ ) samples of the Itaiacoca Group, while, geochronological analyses of zircons from metarhyodacite and metavolcanosedimentary of Bairro dos Prestes Formation yield crystallization and maximum depositional ages of 1,761 \pm 14 and 1,805 $\pm 35 \mathrm{Ma}$, respectively. The geochemical data suggest a tholeiitic to calc-alkaline character for the Itaiacoca Group metabasites, with a MORB and island arc signatures with heterogeneous contribution of subduction zone components, typically of BABB basalts. The positive $\varepsilon \mathrm{N}_{\mathrm{d}(\mathrm{t})}$ values $(+2.3$ to +3.2$)$, imply a dominant juvenile mantle source to the basic magmatism.

The Itaiacoca Group is correlated with Pirapora do Bom Jesus Formation of São Roque Group given the similar lithostratigraphic associations, U-Pb age data and geochemical characteristics. Both are interpreted as deposited in back-arc environment associated with the large Adamastor Ocean, and should represent an Ediacaran suture zone between the Apiaí Terrane and the Paranapanema Craton.

The Bairro dos Prestes Formation is here separated from the Itaiacoca Group due their large differences in depositional settings and volcanic ages. It has acid metavolcanic rocks with metaluminous character and geochemical signatures of high-K calc-alkaline magma series. Its negative $\varepsilon \mathrm{N}_{\mathrm{d}(t)}$ value (-6.8), suggests the recycling of a Neoarchean continental crust ( $\mathrm{T}_{\mathrm{DM}}$ model age of 2,537 Ma). The Bairro dos Prestes Formation is correlated with Boturuna Formation of São Roque Group.

The here recognized Apiaí-Guaçu metasandstone, located on the eastern bank of the river with the same name, yields a maximum depositional age of $588.4 \pm 1.8$. It comprises of fine to coarse-grained feldspathic quartz metasandstone intercalated with small beds of metamudstone. The Apiaí-Guaçu metasandstone is correlated with the molassic or transition stage basins of the Brasiliano Cycle and given the predominance of metamorphic zircons in the detrital grains, the Brasiliano collisional orogen and particularly the Turvo-Cajati Formation is suggested as source area for its sedimentation. 
The finite strain ellipsoids obtained from the SPO analysis performed in the porphyroclasts present oblate shapes with NE-SW strike XY plane and NW-SE steep plunges for X-axis, compatible with the planes and lineation measured in field.

The c-axis fabric of recrystallized quartz grains show cross girdles with maxima concentrations at medium angles between $\mathrm{Z}$ and $\mathrm{X}$, also compatible with flattening fabric shape. They are sensitive to water weakening and solution transfer process modifying the fabric pattern with c-axis maxima at low angles to the stretching lineation, increasing the opening angles and subsequently the calculated temperature. The deformation temperatures calculated between $531^{\circ} \mathrm{C}-593^{\circ} \mathrm{C}$ and $613^{\circ} \mathrm{C}-703^{\circ} \mathrm{C}$, are compatible with the variation from SGR and GBM to GBM regimes, and they also present a tendency to increase from North to South.

These deduced patterns from SPO and LPO analyses suggest a transpressive tectonic regime with predominance of pure shear for the deformation. 


\section{REFERENCES}

Aliani, F., Maanijou, M., Sabouri, Z., Sepahi, A.A., 2012. Petrology, geochemistry and geotectonic environment of the Alvand Intrusive Complex, Hamedan, Iran. Chemie der Erde 72, 363-383.

Almeida, F. F. M. de. 1944. Collenia Itapevensis sp. n. - um fóssil pré-cambriano do Estado de São Paulo. Faculdade de Filosofia, Ciências e Letras, Universidade de São Paulo, Boletim 1, nº 45, 89-106.

Almeida F.F.M. 1969. Diferenciação tectônica da Plataforma Brasileira. In: SBG, Congresso Brasileiro de Geologia, 23, Salvador, 1969. Anais, p. 29-46

Almeida F.F.M., 1956. Novas ocorrências de fósseis no Pré-Cambriano brasileiro. Anais da Academia Brasileira de Ciências, v. 28, 54-55.

Almeida, F.F.M., Hasui, Y., Brito Neves, B.B., 1976. The Upper Precambrian of South America. Boletim IG, Instituto de Geociências, USP, 7, 45-80

Almeida, F.F.M., Hasui, Y., Brito Neves, B.B., Fuck, R.A. 1981. Brazilian structural provinces: an introduction Earth Sci. Rev., 17, 1-21.

Andrade, F.R.D., 2008. Interações fluido-rocha em metadolomites da porção meridional do Grupo Itaiacoca, Paraná. Tese (Livre-Doscência), Instituto de Geociências, Universidade de São Paulo, São Paulo, 170 p.

Archanjo, C.J., Campanha, G.A.C., Salazar, C.A., Launeau, P., 2012. Using AMS combined with mineral shape preferred orientation analysis to understand the emplacement fabric of the Apiai gabbro-norite (Ribeira Belt, SE Brazil). Int. J. Earth Sci (Geol Rundsch) 101, 731-745

Basei, M. A. S., Frimmel, H. E., Nutman, A. P., Preciozzi, F., 2008.West Gondwana amalgamation based on detrital zircon ages from Neoproterozoic Ribeira and Dom Feliciano belts of South America and comparison with coeval sequences from SW Africa. In: Pankhurst, R. J.; Trouw, R. A. J.; Brito Neves, B. B.; WIT, M. J. (Ed.). West Gondwana: Pre-Cenozoic Correlations Across the South Atlantic Region. London: Geological Society London, Special Publication, 239-256.

Basei, M.A.S., Frimmel, H., Nutman, A.P., Preciozzi, F., Jacob, J., 2005. A connection between Neoproterozoic Dom Feliciano Belt (Brazil/Uruguay) and Gariep (Namibia/South Africa) orogenic belts - evidence from a reconnaissance provenance study. Precambrian Research 139, $195-221$.

Batolla, Jr. F., Hama, M., Lopes, Jr. I., 1977. Idades radiométricas Rb/Sr e K/Ar em rochas cristalinas pré-brasilianas da região Este do Paraná. In: Simpósio Regional de Geologia, 1, São Paulo. Atas. São Paulo, SBG. v. 1, 324-337.

Bergmann. M. 1988. Caracterização Estratigráfica e Estrutural da Sequiência Vulcano-Sedimentar do Grupo São Roque na Região de Pirapora do Bom Jesus - Estado de São Paulo. Dissertação de mestrado, Instituto de Geociências, Universidade de São Paulo, 167 pp.

Bergmann. M. e Fairchild. T. R. 1985. Estromatólitos do Grupo São Roque. Proterozóico superior região de Pirapora de Bom Jesus. Estado de São Paulo. Anais da Academia Brasileira de Ciências. 57(1): 116-117. 
Bergmann, M. \& Fairchild, T. R. 1986. Estromatólitos do Grupo São Roque: Uma Hipótese Paleogeográfica. In: XXXIV Congresso Brasileiro de Geologia, Goiânia (GO), Resumos e Breves Comunicações, 1: p.79

Beswick, A.E., 1982. Some geochemical aspects of alteration and genetic relations in komatiitic suites. In: Komatiites, Ardnt, N.T. and Nesbitt, E.G. (eds.). London, George Allen and Unwin, 283308 .

Beswick, A.E., Soucie, G., 1978. A correction procedure for metassomatism in Archean Greenstone belt. Precambrian Research 6, 235-248.

Bigarella, J.J., Salamuni, R. 1956. Estudos preliminares na Série Açungui VII: algumas estruturas singenéticas nos dolomitos da Formação Capiru. Arq. Biol. Tecn., Curitiba, 11-197EBERT, H. 1971. Observações sobre a litologia e subdivisão do "Grupo Setuva" no Estado do Paraná: com sugestões à tectônica geral do "Geossinclíneo Açungui". In.: SBG, Congresso Brasileiro de Geologia, 25, São Paulo, Anais, 1:131-146.

Bistrichi, C.A., Almeida, M.A., Stein, D.P.,1985. Geologia das folhas Barra do Chapéu (SG.22-X-B-I4) e Araçaíba (SG.22-XF-II-3), estados de São Paulo e Paraná. São Paulo, Contrato IPT/ PróMinério, vol. 1, 104 p. (IPT. Relatório 22 150) (inédito).

Blacic, J.D., 1975. Plastic deformation mechanisms in quartz: the effect of water. Tectonophysics 27, 271-294.

Black, L. P., Kamo, S. L., Allen, C. M., Davis, D. W., Alenikoff, J. N., Valley, J. W., Mundif, R., Campbell, I. H., Korsch, R. J., Williams, I. S., Foudoulis C., 2004. Improved 206Pb238U microprobe geochronology by the monitoring of trace element related matrix effect; SHRIMP, ID-TIMS, ELA-ICP-MS and oxygen isotope documentation for a series of zircon standards. Chemical Geology, 205(1), 115-140.

Best, M.G., 2003. Igneous and metamorphic petrology. Second edition. Blackwell Publishing Company, $758 \mathrm{pp}$.

Boynton, W.V., 1984. Geochemistry of Rare Earth Elements Meteorite Studies. In Henderson, P., Ed., Rare Earth Element Geochemistry, Elsevier, New York, 63-114.

Brito Neves, B.B., Campos Neto, M.C., Fuck, R.A., 1999. From Rodinia to Western Gondwana: an approach to the Brasiliano-Pan African cycle and orogenic collage. Episodes 22, 155-166.

Brito Neves, B.B., 2002. Main stages of the development of the sedimentary basins of South America and their relationship with the tectonics of supercontinents. Gondwana Research 175-196.

Brito Neves, B.B., Cordani, U.G., 1991. Tectonic evolution of South America during the Late Neoproterozoic Precambrian Res., 53. 23-40.

Borradaile, G.J., Werner, T., 1994. Magnetic anisotropy of some phyllosilicates. Tectonophysics 235, 223-248.

Caltabellotta, F.P., Silva, M. P., 2016. Departamento de Geologia - DEGEO. Mapa Geológico de Integração do ARIM Vale do Ribeira (SP e PR). Carta Geológica. São Paulo: CPRM, 2016, 1 mapa colorido, 256 x $88 \mathrm{~cm}$. Escala 1:250.000

Campanha G. A. C., 1991. Tectônica Proterozóica no Alto e Médio Vale do Ribeira, Estados de São Paulo e Paraná. Dissertação de Doutorado, Instituto de Geociências, Universidade de São Paulo, 296 pp. 
Campanha, G.A.C., 2002 O papel do sistema de zonas de cisalhamento transcorrentes na configuração da porção meridional da Faixa Ribeira. Tese (Livre-Doscência), Instituto de Geociências, Universidade de São Paulo, São Paulo, 105 p.

Campanha, G.A.C., Basei, M.A.S., Faleiros, F.M., Nutman, A.P., 2016. The Mesoproterozoic to early Neoproterozoic passive margin Lajeado Group and Apiaí Gabbro, Southeastern Brazil. Geoscience Frontiers 7, 683-694.

Campanha, G. A. C., Basei, M. A. S., Tassinari, C.C. G., Nutman, A. P.; Faleiros, F. M., 2008. Constraining the age of the Iporanga Formation with SHRIMP U-Pb zircon: Implications for possible Ediacaran glaciation in the Ribeira Belt, SE Brazil. Gondwana Research, v. 13, 117125.

Campanha, G.A.C., Bistrichi, C.A., Almeida, M.A., 1987. Considerações sobre a organização litoestratigráfica e evolução tectônica da Faixa de Dobramentos Apiaí. SIMP. SUL-BRAS. GEOL., 3. Atas. Curitiba, vol. 2. SBG, pp. 725-742.

Campanha, G.A.C., Faleiros, F.M., 2005. Neoproterozoic terrane collage in the Southern and central Ribeira Belt, Brazil. 12 International Gondwana Symposium 1.

Campanha, G.A.C., Faleiros, F.M., Basei, M.A.S., Tassinari, C.C.G., Nutman, A.P., Vasconcelos, P.M., 2015. Geochemistry and age of mafic rocks from the Votuverava Group,southern Ribeira Belt, Brazil: Evidence for 1490 Ma oceanic back-arcmagmatism. Precambrian Research 266, 530550.

Campanha, G.A.C., Sadowski, G.R., 1999. Tectonics of the southern portion of the Ribeira Belt (Apiaí domain). Precambrian Research 98, 31-51.

Campos Neto, M da C., 2000. Orogenic Systems from Southwestern Gondwana: An Approach to Brasiliano-Pan African Cycle and Orogênic Collage in Southeastern Brazil. In: U.G. Cordani. E.J. Milani. A. Thomaz Filho \& D.A. Campos. (Eds.): Tectonic Evolution of South American. In: XXXI International Geological Congress. Rio de Janeiro. Brazil: 335-365.

Cann, J.R., 1970. Rb, Sr, Y, Zr and Nb in some ocean floor basaltic rocks. Earth Planet. Sci. Letters 10, 7-11.

Carneiro, C. D. R., 1983. Análise Estrutural do Grupo São Roque na Faixa entre o Pico do Jaraguá e a Serra dos Cristais. SP. Tese de Doutoramento. Instituto de Geociências - USP: 155pp.

Carvalho, S.G., Soares, P.C., Antonio, M.C., Zanardo, A., Oliveira, M.A.F., 1993. Geologia da sequiência vulcano-sedimentar de Alpinópolis (MG). R. Bras. Geoc. 23, 38-51.

Chengli, Z., Dingwy, Z., Song, H., Fitches, W.R., Fletcher, C.J.N., 1995. Geochemical characteristics of Danfeng Metavolcanic Rocks in Shangzhou area, Shaanxi Province. Chinese journal of geochemistry, v. 14, 203-211.

Chiodi Filho, C., 1984. Contribuição á geologia das regiões sul paulista e leste paranaense Grupo Açungui e Setuva. In: Congresso Brasileiro de Geologia, 33, Rio de Janeiro, 1984. Anais. Rios de Janeiro, SBG. v.s., 2394-2406.

Chiodi Filho, C.; Takahashi, A.T.; Silva, C.R.; Ferreira, J.C.G., 1983. Projeto Capão Bonito, Relatório Final. São Paulo, Companhia de Pesquisa de Recursos Minerais/PROMINÉRIO, 2v. 
Coleman, R.G., Jove, C., 1992. Geological origin of serpentines. In: Baker, A.J.M., Proctor, J., Reeves, R.D., (eds.). The vegetation of Ultramafic (Serpentine) Soils. International Conference on Serpentine Ecology, 1., Davis, 1991. Proceedings. Hampshire, Intercept, 1-17.

Cordani, U.G. and Bittencourt, I., 1967. Determinação de idades potássio/argônio em rochas do Grupo Açungui. In: Congresso Brasileiro de Geologia, 21, Curitiba. Anais. Curitiba, SBG, 218-233.

Cordani, U.G and Kawashita, K., 1971. Estudo geocronológico pelo método Rb/Sr, de rochas graníticas intrusivas no Grupo Açungui. In: Congresso Brasileiro de Geologia, 25, São Paulo. Anais. São Paulo, SBG. v. 1, 105-110.

Cordani, U.G., Coutinho, J.M.V., Nutman, A.P., 2002. Geochronological constraints on the evolution of the Embu Complex, São Paulo, Brazil. Journal of South American Earth Sciences 14, 903910.

Cordani, U.G., Brito Neves, B.B., D'Agrella, M.S., 2003. From Rodinia to Gondwana: a review of the available evidence from South America. Gondwana Research 6, 275-283.

CPRM, 2011. Mapas de Contorno do Campo Magnético Total Reduzido do IGRF (Campo Total, Primeira Derivada Vertical e Sinal Analítico) e de Contorno Radiométrico em Concentração de Elementos (Contagem Total, Potássio, Urânio, Tório). Escalas 1:100.000 e 1:250.000.

Corfu, F., Hanchar, J.M., Hoskin, P.O.W. \& Kinny, P., 2003. Atlas of zircon textures. In Hanchar, J. M. \& Hoskin, P.W.O. Zircon: Reviews in Mineralogy \& Geochemistry, Vol. 53, 469-500. Washington.

Courtois, C., Clauer, N., 1980. Rare Earth Elements and Strontium Isotopes of Polymetallic Nodules from Southestern Pacific Ocean, Sedimentology 27, 687-695.

Coutinho, J.M.V., 1968a. O Grupo Açungui nas vizinhanças da capital de São Paulo. In: Congresso Brasileiro de Geologia, Belo Horizonte, Res. das Com., p. 2.

Coutinho, J.M.V. 1968b. Petrologia do Pré-Cambriano em São Paulo e Arredores. (Tese - Professor Catedrático) - Faculdade de Filosofia Ciências e Letras - USP: 174 p.

Coutinho, J.M.V., 1971. Estado Atual de Conhecimentos do Pré-Cambriano Superior Sul Brasileiro; Uma Síntese. In: XXV Congresso Brasileiro de Geologia, Anais, 25(1): 83-92

Dantas, A.S.L., 1990. Geologia da Faixa São Roque e Intrusivas Associadas na Região entre São Paulo e Mairiporã. Norte de São Paulo. Dissertação de Mestrado, Instituto de Geociências, Universidade de São Paulo, 199 pp.Dantas, E.L., Hackspacher, P.C., Magini, C., Legrand, J.M., 2002. Sistema Sm-Nd em rocha total aberto versus fechado: Comportamento isotópico em zonas de alta deformação. Revista do Instituto de Geociências, São Paulo. V.2, 109-129.

Den Brok, B., 1992. An experimental investigation into the effect of water on the flow of quartzite. Geologica Ultraiectina 95, 178pp.

Den Brok, S.W.J., Spiers, C.J., 1991. Experimental evidence for water weakening of quartzite by microcracking plus solution-precipitation creep. Journal of the Geological Society, London 148, $541-548$.

DePaolo, D.J., 1988. Neodymium Isotope Geochemistry, An Introduction. Springer-Verlag, Berlin, 187 p. 
DePaolo, D.J., Wasserburg, G.J., 1976. Nd isotopic variations and petrogenetic models. Geophys. Res. Lett. 3, 249-252.

Dostal, J., Chatterjee, A.K., 2000. Contrasting behavior of $\mathrm{Nb} / \mathrm{Ta}$ and $\mathrm{Zr} / \mathrm{Hf}$ ratios in a peraluminous granitic pluton (Nova Scotia, Canada). Chemical Geology 163, 207-218.

Eby, G.N., 1992. Chemical Subdivision of the A-Type Granitoids: Petrogenetic and Tectonic Implications. Geology 20, 641-644.

Fairchild, T.R., 1977. Comophyton and other columnar stromatolites from the upper Precambrian Açungui Group near Itapeva, São Paulo, Brazil. Simp. Reg. Geol., 1, São Paulo, Atas., 179_ 198.

Fairchild, T.R., Theodorovicz, A., 1989. Novas ocorrências de estromatólitos no Grupo Itaiacoca (Proterozóico médio a superior), sul do Estado de São Paulo. XI Congresso Brasileiro de Paleontologia, Curitiba, PR, Resumos, 4 pp.

Faleiros, F.M., 2008. Evolução de terrenos tectono-metamórficos da Serrania do Ribeira e Planoalto Alto Turvo. Dissertação de Doutorado, Instituto de Geociências, Universidade de São Paulo, $318 \mathrm{pp}$.

Faleiros, F.M., Campanha, G.A.C., Bello, R.M.S., Fuzikawa, K., 2010. Quartz recrystallization regimes, c-axis texture transitions and fluid inclusion reequilibration in a prograde greenschist to amphibolite facies mylonite zone (Ribeira Shear Zone, SE Brazil). Tectonophysics 485, $193-$ 214.

Faleiros, F.M., Campanha, G.A.C., Martins, L., Vlach, S.R.F., Vasconcelos, P.M., 2011b. Ediacaran high-pressure collision metamorphism and tectonics of the southern Ribeira Belt (SE Brazil): Evidence for terrane accretion and dispersion during Gondwana assembly. Precambrian Research 189, 263-291.

Faleiros, F.M., Campanha, G.A.C., Pavan, M., Almeida, V.V., Rodrigues, S.W.O., Araújo, B.P., 2016. Short-lived polyphase deformation during crustal thickening and exhumation of a collisional orogen (Ribeira Belt, Brazil). Journal of Structural Geology ,93, 106-130.

Faleiros, F.M., Moraes, R., Pavan, M., Campanha, G.A.C., 2016. A new empirical calibration of the quartz c-axis fabric opening-angle deformation thermometer. Tectonophysics 671, 173-182.

Fassbinder, E., 1996. A unidade Água Clara no contexto do Grupo Açungui: um modelo transpressivo de colisão oblíqua no Neoproterozóico paranaense. Tese de Doutoramento. Instituto de Geociências, Universidade de São Paulo, São Paulo, 207 p.

Faure, G., 1986. Principles of Isotope Geology. John Wiley and Sons (WIE); Edición: 2nd Revised edition, New York. 606 pp.

Faure, G., 2001. Origin of igneous rock: The isotopic evidence. Springer science and business media, Berlin, Heidelberg. 496 pp.Figueiredo, M. C. H., Bergmann, M., Penalva, F., 1982. Ocorrências de pillow lavas no Grupo São Roque, estado de São Paulo. Ciências da Terra. 2: 6-8.

Filho, W.S., Campanha, G.A.C., Fairchild, T.R., 2005. Aspectos deformacionais em estromatólitos do grupo Itaiacoca, a sul de Itapeva (SP). Revista Brasileira de Geociências 35(3), 333-340.

Fitz Gerald, J.D., Mancktelow, N.S., Pennacchioni, G., Kunze, K., 2006. Ultrafine-grained quartz mylonites from high-grade shear zones: evidence for strong dry middle to lower crust. Geology 34, 369-372. 
Fonseca, G.M., 2011. Petrogênese de rochas ultramáficas do quadrilátero ferrífero e adjacências e sua relação genética com rochas metaultramáficas do tipo serpentinito e esteatito. Ouro Preto. Dissertação de Mestrado, Departamento de Geologia, Fundação Universidade Federal de Ouro Preto, 142 pp.

Frascá, M.H.B., 1992. Petrografia e geuímica de rochas carbonáticas pré-Cambrianas do Estado de São Paulo. Tese de mestrado. Instituto de Geociências, Universidade de São Paulo, São Paulo, 168 p.

Fuck, R.A., 1967. Geología da Folha de Abapã. Boletim da Universidade Federal do Paraná, v. 5, 33 p.

Garbutt, J.M., Teyssier, C., 1991. Prism <c> slip in the quartzites of the Oakhurst Mylonite Belt, California. J. Struct. Geol. 13, 657-666.

Gill, J. B. 1976. Composition and age of Lau Basin and Ridge volcanic rocks: implications for evolution of an interarc basin and remnant arc. Bull.geol. Soc. Am. 87, 1384-95.

Gimenez Filho, A., 1993. Evolução do Complexo Granítico Três Córregos a Noroeste de Apiaí, SP. Dissertação de Mestrado. Instituto de Geociências, Universidade São Paulo, São Paulo, 207.

Gimenez Filho, A., Teixeira, W., Figueiredo, M.C.H., Júnior, L.E.T., 1995. Geologia, Petrografia e litogeoquímica do Complexo Granítico Três Córregos na região de Barra do Chapéu e Ribeirão Branco, SP. Revista Brasileira de Geociências 25, 92-106.

Gladkochub, D.P., Donskaya, T.V., Reddy, S.T., Poller, U., Bayanova, T.B., Mazukabzov, A.M., Dril, S., Todt, W., Pisarevsky, S.A., 2009. Paleoproterozoic to Eoarchaean crustal growth in southern Siberia: a Nd-isotope synthesis. Geological Society, London, Special Publications 323, 127 143.

Gleason, G.C., Tullis, J., Heidelbach, F., 1993. The role of dynamic recrystallization in the development of lattice preferred orientations in experimentally deformed quartz aggregates. J. Struct. Geol. $15,1145-1168$.

Green, T.H., 1995. Significance of $\mathrm{Nb} / \mathrm{Ta}$ as na indicator of geochemical processes in the crust-mantle system. Chemical Geology 120, 347-359.

Griggs, D.T., Blacic, J.D., 1965. Quartz: anomalous weakness of synthetic crystals. Science 147, $292-$ 295.

Guimarães, G.B., 2000. As rochas granitoides do Complexo Granítico Cunhaporanga: Aspectos geológicos, geofísicos, geoquímicos e mineralógicos. Dissertação de Doutorado. Instituto de Geociências, Universidade São Paulo, São Paulo, 337.

Hackspacher, P.C., Dantas, E.L., Spoladore, A., Fetter, A.H., Oliveira, M.A.F., 2000. Evidence for Neoproterozoic back-arc basin development in the Central Ribeira Belt, southeastern Brazil: new geochronological and geochemical constraints from the São Roque-Açungui Groups. Revista Brasileira de Geociências, 30, 110-114.

Hanchar, J.M., Westrenen, W. V., 2007. Rare earth element behavior in zircon-melt systems. Elements $3,37-42$. 
Hastie, AR., Kerr, A.C., Pearce, J.A., Mitchell, S.F., 2007. Classification of altered volcanic island arc rocks using immobile trace elements: Development of the Th-Co discrimination diagram. Journal of petrology, V 48, number 12, 2341-2357.

Hasui, Y., 1973. Tectônica da área das folhas de São Roque e Pilar do Sul. São Paulo. Tese LivreDocência - Instituto de Geociências - USP: 134 pp.

Hasui, Y., 1975. Geologia da Folha de São Roque. Boletim do Instituto de Geociências -USP, 6: 157183.

Hasui, Y., 1986. Novo modelo geológico do Vale do Ribeira. São Paulo, IPT, Relatório 23, 742.

Hasui, Y., Cremonini, O.A., Born, H., 1984a. Considerações sobre o Grupo Açungui em São Paulo e porção adjacente no Paraná. 33Congresso Brasileiro de Geologia, vol. 7. Anais. SBG, Rio de Janeiro, 3297-3306.

Hasui, Y., Cremonini, O.A., Born, H., 1984b. O “Granito Trêsn Córregos" revisado e o Maciço Catas Altas., In: Congreso Brasileiro de Geologia, 23, Rios de Janeiro. Anais. Rio de Janeiro, SBG. V.7, 3023-3031

Hasui, Y., Sadowski, G. R., 1976. Evolução geológica do Pré-cambriano na região sudeste do Estado de São Paulo. Revista Brasileira de Geociências, 6(3): 182-200.

Hasui. Y; Sadowski, G. R; Carneiro, C.D.R., 1976. Considerações Sobre a Estratigrafia do PréCambriano na Região de São Paulo. Boletim Instituto de Geociências - USP. 7: 107-112.

Hasui, Y., Oliveira, M.A.F., 1984. Província Mantiqueira. Setor Central. In: Almeida, F.F., Hasui. O Pre-Cambriano do Brasil. São Paulo, Edgar Blucher Ltda, 308-344.

Hawkesworth, C.J., O’Nions, R.K., Pankhurst, R.J., Hamilton, P.J., Evensen, N.M., 1977. A geochemical study of island-arc and back-arc tholeiites from the Scotia Sea. Earth planet. Sci. Letters 36, 253-262.

Heilbron, M., Pedrosa-Soares, A.C., Campos Neto, M.C.; Silva, L.C., Trouw, R.A.J., JanasI, V. A., 2004. Província Mantiqueira. In: Mantesso Neto, V., Bartorelli, A., Carneiro, C.D.R., BritoNeves, B.B. de. (Orgs.) 2004. Geologia do Continente Sul-americano: São Paulo: ed. Beca, 203236.

Helbig, M., Keppie, J.D., Murphy, J.B., Solari, L.A., 2013. Exotic rifted passive margin of back-arc basin off western Pangea: Geochemical evidence from the Early Mesozoic Ayú Complex, souther Mexico. International Geology Review, vol. 55, No. 7, 863-881.

Heilbronner, R., Tullis, J., 2006. Evolution of c-axis pole figures and grain size during dynamic recrystallization: results from experimentally sheared quartzite. J. Geophys. Res. 111, B10202.

Henderson, P., Pankhurst, R.J., 1984. Analytical chemistry. In: Henderson P. (Ed.). Rare earth element geochemistry. Elsevier, Amsterdam, 467-499.

Henrique-Pinto, R., Janasi, V.A., Vasconcellos, A.C.B.C., Sawyer, E.W., Barnes, S.-J.,Basei, M.A.S., Tassinari, C.C.G., 2015. Zircon provenance in meta-sandstones ofthe São Roque Domain: implications for the Proterozoic evolution of the RibeiraBelt, SE Brazil. Precambrian Res. 256, 271-288.

Hippertt, J.E., 1994. Microstructures and c-axis fabrics indicative of quartz dissolution in sheared quartzites and phyllonites. Tectonophysics 229, 141-163. 
Hirth, G., Tullis, J., 1992. Dislocation creep regimes in quartz aggregates. J. Struct. Geol. 14, 149-159.

Hobbs, B.E., 1968. Recrystallization of single crystals of quartz. Tectonophysics 6, 353-401.

Hobbs, B.E., 1985. The geological significance of microfabric analysis. In:Wenk, H.-R. (Ed.), Preferred Orientation in Deformed Metals and Rocks: an Introduction to Modern Texture Analysis. Academic Press, Orlando, 463-484.

Huang, S.G.L.F., Nie, Y.H., Han, W.L., Long, G., Li, H.M., Zhang, S.Q., Zhang, Z.H., 2001. Geochemical and geochronological constraints on the suture location between the North and South China blocks in the Dabie Orogen, Central China. Phys. Chem. Earth (A), v. 26, No. 9$10,655-672$.

Huber M.I. 1987. The Techniques of Modern Structural Geology. Volume II: Folds and Fractures. London, Academic Press, 391.

Irvine, I.N., Baragar, W.R.A., 1971. A guide to the chemical classification of the common volcanic rocks. Canadian Journal Earth Science 8, 523-548.

Janasi, V.A., Leite, R.J., Van Schmus, W.R., 2001. U-Pb ages and chronostratigraphyof the granitic magmatism in the Agudos Grandes batholith (W of Sao Paulo,Brazil) - implications for the evolution of the Ribeira Belt. J. South Am. Earth Sci.14, 363-376.

Janousek, V., Farrow, C.M., Erban, V., 2006. Interpretation of whole-rock geochemical data in igneous geochemistry: introducing Geochemical Data Toolkit (GCDkit). J. Petrol. 47, 1255-1259.

Janousek, V., Farrow, C.M., Erban, V., Trubac, J., 2011. Brand new Geochemical Data Toolkit (GCDkit 3.0) - is it worth upgrading and browsing documentation? (Yes!). Geologicke vyzkumy na Morave a ve Slezsku 18, 26-30.

Jaoul, O., Tullis, J., Kronenberg, A.K., 1984. The effect of varying water contents on the creep behavior of Heavitree quartzite. J. Geophys. Res. 89, 4298-4312.

Jayananda, T.M., 2013. Geochemical constraints on komatiite volcanism from Sargur Group Nagamangala greenstone belt, western Dharwar craton, southern India: Implications for Mesoarchean mantle evolution and continental growth. Geoscience Frontiers 4, 321-340.

Jelinek, V., 1981. Characterization of the magnetic fabric of rocks. Tectonophysics 78, 63-67.

Juliani, C., Beljavskis, P., Schorscher, H.D., 1986. Petrogênese do vulcanismo e aspectos Metalogenéticos Associados: Grupo Serra do Itaberaba na Região do São Roque e SP. In: XXXIV Congresso Brasileiro de Geologia. Goiânia. Anais, vol. 2, 730-745.

Juliani C., Martin M.A.B., Clarimundo S. de J., McReath I., Pertersen Jr. K.J., 1999. Geologia dos Grupos Serra do Itaberaba e São Roque entre o Pico do Jaraguá e Araçarigüama, São Paulo. In: SBG/NSP-NRJ/ES, Simpósio de Geologia do Sudeste, Águas de São Pedro, Boletim de Resumos, 6-26.

Juliani, C., Hackspacher, P.C., Dantas, E.L., Fetter, A.H., 2000. The Mesoproterozoic volcanosedimentary Serra do Itaberaba Group of the central Ribeira Belt, São Paulo State, Brazil: implications for the age of the overlying São Roque Group. Revista Brasileira Geociencias. 30(1): 82-86. 
Kaulfuss, G. A., 2001. Geocronologia dos Núcleos de Embasamento Setuva, Betara e Tigre, Norte de Curitiba, Paraná. Dissertação de Doutorado, Instituto de Geociências, Universidade de São Paulo, 115 pp.

Keller, L.M., Stipp, M., 2011. The single-slip hypothesis revisited: crystal-preferred orientations of sheared quartz aggregates with increasing strain in nature and numerical simulation. J. Struct. Geol. 33, 1491-1500.

Keshavarzi, R., et al. (2014) Petrology, Geochemistry and Tectonomagmatic Setting of Neshveh Intrusion (NW Saveh). Open Journal of Geology 4, 177-189.

Kirschner, D., Teyssier, C., 1991. Quartz c-axis fabric differences between porphyroclasts and recrystallized grains. Journal of Structural Geology 13, 105-109

Kruhl, J.H., 1996. Prism- and basal-plane parallel subgrain boundaries in quartz: a microstructural geothermobarometer. J. Metamorph. Geol. 14, 581-589.

Kruhl, J.H., 1998. Reply: prism- and basal-plane parallel subgrain boundaries in quartz: a microstructural geothermobarometer. J. Metamorph. Geol. 16, 142-146.

Kruhl J.H., Peternell M., 2002. The equilibration of high-angle grain boundaries in dynamically recrystallized quartz: the effect of crystallography and temperature. J Struct Geol 24, $1125-$ 1137.

Lagroix, F., Borradaile, G.J., 2000. Magnetic fabric interpretation complicated by inclusions in mafic silicates. Tectonophysics 325, 207-255.

Launeau, P., Bouchez J.L., Keith B., 1990. Shape preferred orientation of object population: automatic analysis of digitized images. Tectonophysics 180, 201-211.

Launeau P, Cruden A.R., 1998. Magmatic fabric acquisition mechanisms in a syenite: results of a combined anisotropy of magnetic susceptibility and image analysis study. J. Geophysical Research. 103, 5067-5089.

Launeau, P., Robin P.Y.F., 1996. Fabrics analysis using the intercept method. Tectonophysics 267, 91119

Launeau, P., Robin, PY.F., 2003b. SPO. Université de Nantes (France)/ University of Toronto

(Canadá). Available http://www.sciences.univ-nantes at:.fr/geol/UMR6112/SPO/SPO.html.

Launeau, P., Robin, P. Y. F., 2003c. ELLIPSOID. Université de Nantes (France)/ University of Toronto (Canadá). Available at: http://www.sciences.univnantes.fr/geol/UMR6112/SPO/Ellipsoid.html.

Launeau P, Robin P.Y., 2005. Determination of fabric and strain ellipsoids from measured sectional ellipses-implementations and applications. J Struct Geol 27, 2223-2233.

Law, R.D., Casey, M., Knipe, R.J., 1986. Kinematic and tectonic significance of microstructures and crystallographic fabrics within quartz mylonites from the Assynt and Eriboll regions of the Moine thrust zone, NW Scotland. Trans. R. Soc. Edinb. Earth Sci. 77, 99-126.

Law, R.D., 1987. Heterogeneous deformation and quartz crystallographic fabric transitions: natural examples from the Moine Thrust zone at the Stack of Glencoul, northern Assynt. Journal of Structural Geology 9, 819-833. 
Law, R.D., 1990. Crystallographic fabrics: a selective review of their applications to research in structural geology. In: Knipe, R.J., Rutter, E.H. (Eds.), Deformation Mechanisms, Rheology and Tectonics: Geological Society of London Special Publication 54, 335-352.

Law, R.D., 2014. Deformation thermometry based on quartz c-axis fabrics and recrystallization microstructures: A review. Journal of Structural Geology 66, 129-161.

Law, R.D., Stahr, D.W., Francsis, M.K., Ashley, K.T., Grasemann, B., Ahmad, T., 2013. Deformation temperatures and flow vorticities near the base of the Greater Himalayan Series, Sutlej Valley and Shimla Klippe, NW India. J. Struct. Geol. 54, 21-53.

Lazzari, M. L., 1987. O Metabasito de Pirapora do Bom Jesus. Dissertação de maestria, Instituto de Geociências, Universidade de São Paulo, 84 pp.

Lima, R.E., 1993b. Geologia da Faixa Itaiacoca / PR: Estratigrafia, litologias, depósitos de talco e intrusivas associadas. In: Simpósio Sul Brasileiro de Geologia, 5. Anais. Curitiba: SBG, v. 2, 30-35.

Lisle, R.J., 1977. Clastic grain shape and orientation in relation to cleavage from the Aberystwyth Grits, Wales. Tectonophysics 39, 381-385

Lister, G. S., 1977. Discussion: Crossed girdle c-axis fabrics in quartzites plastically deformed by plane strain and progressive simple shear. Tectonophysics 39, 51-54.

Lister, G.S., 1981. The effect of the basal-prism mechanism switch on fabric development during plastic deformation of quartz. J. Struct. Geol. 3, 67- 76.

Lister, G.S., Dornsiepen, U.F., 1982. Fabric transitions in the Saxony Granulite Terrain. Journal of Structural Geology 4, 81-92.

Lister, G.S., Hobbs, B.E., 1980. The simulation of fabric development during plastic deformation and its application to quartzite: fabric transitions. J. Struct. Geol. 2, 355-370.

Ludwig, K.R., 2003. Isoplot 3.00: A Geochronological Toolkit for Microsoft Excel. Berkeley Chronology Center Special Publication No. 4, Berkeley, CA.

Mahoney, J.J., Saunders, A.D., Storey, M., Randriamanantenasoa, A., 2008. Geochemistry of the Volcan de L'Androy Basalt-Rgyolite Complex, Madagascar Cretaceous Igneous ProviSAYnce. Journal of petrology, v. 49. No. 6, 1069-1096.

Mancktelow, N.S., Pennacchioni, G., 2004. The influence of grain boundary fluids on the microstructure of quartz-feldspar mylonites. J. Struct. Geol. 26, 47-69.

Malpas, J., 1991. Serpentine and the geology of serpentinized rocks. In: ROBERTS, B.A. \& PROCTOR, J., (eds.). The ecology of areas with serpentinized rocks. A world view. Dordrecht, Kluwer Academic, 7-30.

Marini, O.J and Bigarella, J.J. 1967. Rochas calcárias do Grupo Açungui. Boletim Paranaense de Geociências, n. 23-25, p. 105-150.

Marini, O.J and Bósio, N.J. 1971. Estromatólitos em dolomitos do Grupo Açungui. Anais da Academia Brasileira de Ciências, v. 43, n.1, p. 161-175. 
Martin, M. A. B., 2000. Geologia e Petrografia e Metamorfismo dos Grupos Serra do Itaberaba e São Roque a Noroeste da Cidade de São Paulo (SP). Dissertação de mestrado, Instituto de Geociências, Universidade de São Paulo, 256 pp.

McCuaig, T.C., Kerrich, R., Xie, Q., 1994. Phosphorous and high field strength element anomalies in Archean high-magnesian magmas as possible indicators of source mineralogy and depth. Earth and planetary science letter 124, 221-239.

Melcher, G.C., Girardi, C.B., Cordani, U.G., Bettencourt, J., Damasceno, E.C., Girardi, V.A.V., Melfi, A.J., 1973. Geologia e petrologia das rochas metamórficas e graniticas associadas do vale do rio Ribeira de Iguape, SP e PR. Revista Brasileira de Geociências 3(2), 97-123.

Menegon, L., Pennacchioni, G., Heilbronner, R., Pittarello, L., 2008. Evolution of quartz microstructure and c-axis crystallographic preferred orientation within ductilely deformed grainitoids (Arolla unit, Western Alps). Journal of Structural Geology 30, 1332-1347.

Meschede, M., 1986. A method of discrimination between different types of mid-ocean ridge basalts and continental tholeiites with the Nb-Zr-Y diagram. Chemical Geology, 56, 207-218.

Mesquita, M.J., Bitencourt, M.G., Picanço, J., Vasconcellos, E.M.G., Moreto, A.L.R., 2013. Evolução microstructural do Granito Água Compreda e formação de filonitos, Antiforme Setuva, Paraná. São Paulo, UNESP, Geociências, v. 32, n. 2, 269-285.

Misra, K, C, 2012. Introduction to Geochemistry: Principles and applications. John Wiley and Sons, Ltda., Publication, The Atrium, Southern Gate, Chichester.

Moraes, R., L. F. de., 1933. Contribuição ao estudo das formações pré-devonianas de São Paulo. Boletim do Instituto Astronômico e Geographico. São Paulo - SP: 55pp.

Moreto, A.L.R., Vasconcellos, E.M.G., Reis Neto, J.M., 2008. Caracterização faciológica do filito branco da região de Itapeva-SP. Boletim Paranaense de Geociências, n. 62-63, 7-21. Editora UFPR.

Morgan, S.S., Law, R.D., 2004. Unusual transition in quartzite dislocation creep regimes and crystal slip systems in the aureole of the EJB pluton, California: a case for anhydrous conditions created by decarbonation of adjacent marbles. Tectonophysics 384, 209-231.

Moro, R.P.X., 2000. Propostas de origem, evolução e contexto da bacia da Formação Camarinha transição Neoproterozóico-Eocambriano do Estado do Paraná. Dissertação de Doutorado, Instituto de Geociências, Universidade de São Paulo, 167 pp.

Muto, J., Hirth, G., Heilbronner, R., Tullis, J., 2011. Plastic anisotropy and fabric evolution in sheared and recrystallized quartz single crystals. J. Geophys. Res. 116, B02 206.

Nakamura, N., Borradaile, G., 2004. In: Martín-Hernández, F., Luneburg, C.M., Aubourg, C., Jackson, M. (eds) 2004. Magnetic fabric: Methods and applications. Geological Society. London. Special Publications 238, 61-68.

Okudaira, T., Takeshita, T., Hara, I., Ando, J., 1995. A new estimate of the conditions for transition from basal <a> to prism [c] slip in naturally deformed quartz. Tectonophysics 250, 31-46.

Okudaira, Takeshita, T., Toriumi, M., 1998. Discussion: prism- and basal-plane parallel subgrain boundaries in quartz: a microstructural geothermometer. J. Metamorph. Geol. 16, 141-142. 
Ohki, J., Shuto, K., Kagami, H., 1994. Middle Miocene bimodal volcanism by asthenospheric upwelling: $\mathrm{Sr}$ and $\mathrm{Nd}$ isotopic evidence from the back-arc region of the Northeast Japan arc. Geochemical Journal, Vol. 29, 473-487.

Oliveira, M.A.F., Melo, R.P., Nardy, A.J., Arab, P.B., 2008. New U/Pb Paleoproterozoic zircon age for the Cajamar metabasite, São Roque Group, central Ribeira Belt, Southeastern Brazil. VI South American Symposium on Isotope Geology. Argentina.

Paoliello, P. C., 1964. Geologia do Estado de São Paulo - Explanação do Mapa Geológico. Boletim I.G.G., 41: 37-44.

Passarelli, C. R. 2001. Caracterização estrutural e geocronológica dos domínios tectônicos da porção sul-oriental do Estado de São Paulo. Dissertação de Doutorado, Instituto de Geociências, Universidade de São Paulo, 254 pp.

Passchier, C.W., Trouw, R.A.J., 2005. Microtectonics. Berlim Heidelberg, Springer-Verlag, 289. Evolução microestructural do Granito Água Comprida e formação de filonitos, Antiforme Setuva, Paraná. São Paulo, UNESP, Geociências, v. 32, n.2, 269-285.

Passchier, C.W., Trouw, R.A.J., 2005. Microtectonics. Berlim Heidelberg, Springer-Verlag, 289 pp.

Pearce, J.A., 1982. Trace element characteristics of lavas from destructive plate boundaries. In Andesites: Orogenic Andesites and Related Rocks, ed. Thorpe, R.S., 525-548. Chichester: Wiley.

Pearce, J.A., 1996. Sources and setting granitic rocks. Episodes 19 (4), 120-125.

Pearce, J.A., 2008. Geochemical fingerprinting of oceanic basalts with applications to ophiolite classification and the search for Archean oceanic crust. Lithos 100, 14-48.

Pearce, J.A, Harris, N.B.W., Tindle, A.G., 1984. Trace element discrimination diagrams for the tectonic interpretation of granitic rocks. Journal of petrology, 25(4), 956-983.

Pearce, J.A., Norry, M.J., 1979. Petrogenetic implications of Ti, Zr, Y, and Nb variations in volcanic rocks. Contributions to Mineralogy and Petrology 69, 33-47.

Pearce, J.A., Peate, D.W., 1995. Tectonic implications of the composition of volcanic magmas. Annual Reviews Earth Planet Sci. 23, 215-285.

Pearce, T.H., 1968. A contribution to the theory of variations diagrams. Contributions Mineralogy and Petrology 19, 42-57.

Petri, D.S., Suguio, K., 1969. Sobre os metassedimentos do Grupo Açungui do extremo Sul do Estado de São Paulo. Convênio cadeira de estratigrafia e sedimentologia e serviço do Vale do Ribeira. Secretaria dos serviços e obras pública faculdade de Filosofia, Ciências e Letras. Universidade de São Paulo. Brasil.

Petronilho, L.A., 2009. Método Sm-Nd no CPGEO-IGC-USP: Procedimentos analíticos atualmente em rotina. In: Simpósio - 45 Anos de Geocrologia no Brasil, 2009, São Paulo. Simpósio 45 Anos de Geocronologia no Brasil - Boletim de Resumos Expandidos. São Paulo: USP - IGC. v. I. p. $116-118$

Prazeres Filho, H. J., 2005. Caracterização geológica e petrogenética do Batólito Granítico Três Córregos (PRSP): Geoquímica Isotópica (Nd-Sr-Pb. Idades (ID-TIMS / SHRIMP) e O18 em zircão. Dissertação de Doutorado, Instituto de Geociências, Universidade de São Paulo, 207 pp. 
Prazeres Filho, H.J., Guimarães, G., Basei, M.A.S., Siga Júnior, O., Reis Neto, J.M., Campanha, G.A.C., Sallun Filho, W., 1998. Mapa geológico 1:50,000 da porção centro-sul da Faixa Itaiacoca-PR. XL Congresso Brasileiro de Geologia. SBG, Belo Horizonte (MG), p. 36.

Prazeres Filho, H.J., Harara, O.M., Basei, M.A.S., Passarelli, C.R., Siga Jr., O., 2003. Litoquímica, Geocronologia U-Pb e Geologia isotópica ( $\mathrm{Sr}-\mathrm{Nd}-\mathrm{Pb})$ das rochas graníticas dos Batólitos Cunhaporanga e Três Córregos na Porção Sul do Cinturão Ribeira, Estado do Paraná. Revista do Instituto de Geociências - USP, 3, 51-70.

Ramsay, J.G., 1967. Folding and Fracturing of Rocks. McGraw-Hill, New York, pp. 56

Ramsay J.G., Huber M.I., 1987. The Techniques of Modern Structural Geology. Volume II: Folds and Fractures. London, Academic Press, 391 p.

Reis Neto, J.M., 1994. Faixa Itaiacoca: registro de uma colisão entre dois blocos continentais no neoproterozóico. Dissertação de Doutorado, Instituto de Geociências, Universidade de São Paulo, 253 pp.

Riccomini, C., 1993b. Origem, evolução e inversão da Bacia do Pico de Itapeva, NeoproterozóicoCambriano, São Paulo, Brasil. In: DINAMIGE-Fac. Agron., Simp. Intern. Del NeoproterozoicoCambrico de la Cuenca del Plata, 1, La Paloma-Minas, Resumenes Extensos, Tomo I, res.16.

Robin, P.YF., 2002. Determination of fabric and strain ellipsoids from measured sectional ellipsestheory. J Struct Geol 24, 531-544.

Rölller, K., Trepmann, C. A., 2003. Stereo32 1.0.3. Institut für Geologie - Ruhr University Bochum: Bochum, DE.

Rollinson, H.R., 1993. Using geochemical data: Evaluation, presentation, interpretation. New York, John Wiley and Sons.

Sadowski, G.R., Tassinari, C.C.G., 1991. The São Roque Volcano-Sedimentary Sequence of Proterozoic Age. Excursion Guide Book. 7th International Gondwana Symposium, 26p. São Paulo, Brazil.

Salazar, C.A., 2010. Anisotropia de sysceptibilidade magnética dos plútons Ribeirão Branco, Sguário e Capão Bonito e implicações tectônicas para a Faixa Ribeira (Domínio Apiaí, SP). Dissertação de Doutorado, Instituto de Geociências, Universidade de São Paulo, 165 pp.

Salazar, C.A., Archanjo, C.J., Rodrigues, S.W.R., Hollanda, M.H.B.M., 2013. Age andmagnetic fabric of the Três Córregos granite batholith: evidence for Ediacarantranstension in the Ribeira Belt (SE Brazil). Int. J. Earth Sci. 102, 1563-1581.

Sallun Filho, W., 1999. Análise dos estromatólitos do Grupo Itaiacoca (Proterozóico), ao sul de Itapeva, SP. Dissertação de Mestrado, Instituto de Geociências, Universidade de São Paulo, 126 pp.

Sallun Filho, W.; Campanha, G.A.C.; Fairchild, T.R., 2005. Aspectos deformacionais em estromatólitos do Grupo Itaiacoca, a sul de Itapeva (SP). Revista Brasileira de Geociências, v. 35, n. 3, 419430 .

Sallun Filho, W., Fairchild, T.R., 2000. Stromatolites in the Mesoproterozoic Itaiacoca Group (SE Brazil): Paleoenvironmental inferences and comparisons with other similar forms. Sessions of the academia Brasileria de ciências. Anais da Academia Brasileira de Ciencias, 72 (4). 
Sallun Filho, W., Fairchild, T.R., 2004. Estromatólitos do grupo Itaiacoca ao Sul de Itapeva, Estado de São Paulo, Brasil. Revista Brasileira de Paleontologia, 7 (3), 359-370.

Sallun Filho, W., Fairchild, T.R., 2005. Estudo comparativo entre estromatólitos do tipo CONOPHYTON das Faixas Ribeira e Brasília. Revista do Instituto Geológico de São Paulo 26 $(1 / 2), 1-18$.

Santoro, E., 1998. Evolução geológica do Pré-cambriano da região de Santo Antônio do Pinal, SP: Importância tectônica das zonas de cisalhamento. Dissertação de Doutorado, Instituto de Geociências, Universidade de São Paulo, 173 pp.

Santoro, E., Frasca, M.H.B., 1989. A Formação Itaiacoca na região de Itapeva, SP. 1Simpósio de Geologia do Sudeste, 1. SBG, Rio de Janeiro (RJ), pp. 99-100.

Sato, K., Basei, M.A.S., Ferrerira, C.M, Vlach, S.R.F., Ivanuch, W, Siga Jr, O., Onoi, A.T., 2010. In Situ U-Th-Pb isotopic analyses by excimer laser ablation/ ICP-MS on Brazilian xenotime megacrytal: First U-Pb results a CPGeo-IG-USP. VII SSAGI, CD Room, Brasilia, DF.

Sato K., Tassinari, C.C.G., Basei, M.A.S., Siga Jr, O., Onoe, A.T., Souza, M.D., 2014. Sensiti high resolution Ion Microprobe (SHRIMP IIe/MC) of the Institute of Geosciences of the University of São Paulo, Brazil: analytical method and first results. Revista do Instituto de Geociências USP. v, 14, 3-18.

Sato, K., Tassinari, C.C.G., Kawashita, K., Petronilho, L., 1995. O método geocronológico Sm-Nd no IG/USP e suas aplicações. Anais da Academia Brasileira de Ciências 67, 315-336.

Saunders, A.D., Tarney, J., 1984. Geochemical characteristics of basaltic volcanism within back-arc basins. Geological Society, London, Special Publications 16, 59-76

Saunite, D.M., Bello, R.M.S., Andrade, F.R.D., Szabó, G.A.J., 2011. Metadolomitos talcificados do Grupo Itaiacoca, Paraná: Regime de Fluidos e implicações genéticas. Revista do instituto de Geociências - USP 1, 171-187.

Schandl, E. S. and Gorton, M. P., 2002- Application of high strength elements to discriminate tectonic setting in VMS environments. Economic Geology, 97: 629-642.

Schmid, S.M., 1994. Textures of geological materials: computer model predictions versus empirical interpretations based on rock deformation experiments and field studies. In: Bunge HJ, Siegesmund S, Skrotzki W, Weber K (eds) Textures of geological materials. DGM Informationsges, Oberursel, 279-301

Schmid, S.M., Casey, M., 1986. Complete fabric analysis of some commonly observed quartz c-axis patterns in mineral and rock deformation. In: Hobbs, B.E., Heard, H.C. (Eds.), Mineral and rock deformation: laboratory studies: The Paterson Volume: American Geophysical Union, Geophysical Monograph 36, 263-286.

Shand, S. J. (1943). Eruptive Rocks. Their Genesis, Composition, Classification, and Their Relation to Ore-Deposits with a Chapter on Meteorite. New York: John Wiley \& Sons.

Shikazono, N., 2003. Geochemical and Tectonic Evolution of Arc-Backarc Hydrothermal Systems: Implication for the Origin of Kuroko and Epithermal Vein-Type Mineralizations and the Global Geochemical Cycle. Elsevier Science Volume 8 1st Edition., 478 pp.

Siga Jr., O., 2010. Geocronologia da porção sul do Terreno Apiaí: implicações tectônicas. Tese (LivreDoscência), Instituto de Geociências, Universidade de São Paulo, São Paulo. 
Siga Jr., O., Basei, M.A.S., Nutman. A., Sato, K., McReath, I., Passarelli, C.R., Liu, D., 2011c. Extensional and Colisional Magmatic Records in the Apiaí Terrane, South-Southeastern Brazil: Integration of Geochronological U-Pb Zircon Ages. Revista do Instituto de Geociências -USP. V. 11, n.3, 149-175.

Siga Jr., O., Basei, M.A.S., Sato, K., Passarelli, C.R., Nutman. A., McReath, I., Filho, H.J.P., 2011 b. Calymmian $(1.50 \mathrm{e} 1.45 \mathrm{Ga})$ magmatic records in Votuverava and Perau sequences, southsoutheastern Brazil: Zircon ages and NdeSr isotopic geochemistry. J. South America Earth Sciences 32, 301-308.

Siga Jr., O., Basei, M.A.S., Sato, K., Prazeres Filho, H.J., Cury, L.F., Weber, W., Passarelli, C.R., Harara, O.M., Reis Neto, J.M., 2003. U-Pb (Zircon) ages of metavolcanic rocks from the Itaiacoca Group: Tectonic implications. Revista do Instituto de Geociências -USP. V. 3, 39-49.

Siga Jr., O., Basei, M.A.S., Passarelli, C.R., Sato, K., Cury, L.F., Mcreath, I., 2009. Magmatic records of lower neoproterozoic and upper neoproterozoic in Itaiacoca belt (Paraná- Brazil): zircon ages and lithostratigraphy studies. Gondwana Research 15, 197-208.

Siga JR., O., Cury, L. F., Mcreath, I., Ribeiro, L. M. A. L., Sato, K., Basei, M. A. S., Passarelli, C. R., 2011a. Geology and Geochronology of the Betara Region in South-Southeastern Brazil: Evidence for Possible Statherian (1.80-1.75 Ga) and Calymmian (1,50-1.45 Ga) Extension Events. Gondwana Research, v. 19, 260-274.

Silva, L.C., Pedrosa Soares, A.C., Teixeira, L.R., Armstrong, R., 2008. Tonian rift-related, Atype continental plutonism in the Araçuaí Orogen, eastern Brazil: new evidence for the breakup stage of the São Francisco-Congo Paleocontinent. Gondwana Research 13, 527-537

Soares, P.C., 1987a. Seqüências tectono-sedimentares e tectônica deformadora no centrooeste do Escudo Paranaense. III Simpósio Sul Brasileiro de Geologia, SBG. Curitiba, vol. 1, pp. 245258.

Soares, P.C., Stevanatto, R., Camargo, C.R., 1987b. Geologia do Nordeste da Faixa Itaiacoca-Paraná. III Simpósio Sul-Brasileiro de Geologia. Curitiba, vol. 1, pp. 245-262.

Soares, P. C.; Stevanato, R.; Camargo, C. R, 1987b. Geologia do noroeste da Faixa Itaiacoca. In: III Simpósio Sul-Brasileiro DE Geologia, Curitiba. Anais. v. 2, p. 245-26.

Souza, A.P., 1990. Mapa Geológico na Escala 1:50.000 e esboço de evolução tectônica e sedimentar do Grupo Itaiacoca, nas Folhas Barra do Chapéu e Ouro Verde (SP) - (PR). Dissertação de Mestrado, Instituto de Geociências, Universidade de São Paul, 233 pp.

Souza, A. Pereira.,1992. Litoestratigráfica e Tectônica da Faixa Itaiacoca. In: XXXVII Congresso Brasileiro de Geologia, São Paulo (SP). Boletim de Resumos Expandidos.

Spear, F.S., Kohn, M.J., Cheney, J.T., 1999. P-T paths from anatectic pelites. Contrib Mineral Petrol $134,17-32$.

Stacey, S., Kramers, J.D. Approximation of terrestrial lead isotope evolution by a two-stage model. Earth and Planetary Science Letters, 26 (1975), pp. 207-221.

Stallard, A., Shelley, D., 1995. Quartz c-axes parallel to stretching directions in very low-grade metamorphic rocks. Tectonophysics 249, 31-40. 
Stipp, M., Stünitz, H., Heilbronner, R., Schmid, S.M., 2002a. The eastern Tonale fault zone: a 'natural laboratory' for crystal plastic deformation of quartz over a temperature range from 250 to 700 ${ }^{\circ} \mathrm{C}$. Journal of Structural Geology 24, 1861-1884.

Stipp, M., Tullis, J., Behrens, H., 2006. Effect of water on the dislocation creep microstructure and flow stress of quartz and implications for the recrystallized grain size piezometer. J. Geophys. Res. 111, B042201.

Sun, S.S. and McDonough, W.F. (1989). Chemical and isotopic systematics of oceanic basalts; implications for mantle composition and processes. In: Magmatism in the ocean basins. Saunders, A.D. and Norry, M.J. (Editors), Geological Society of London, London. 42: 313-345.

Szabó, G.A.J., Andrade, F.R.D., Guimarães, G.B., Carvalho, F.M.S., Moya, F.A., 2006. As jazidas de talco no contexto da história metamórfica dos metadolomitos do Grupo Itaiacoca, PR. Revista do Instituto de Geociências - UPS, v. 5, 13-31.

Takahashi, A.T.; Ferreira, J.C.G.; Theodorovicz, A, 1984. Projeto Guapiara. Relatório Final. CPRM/PROMINÉRIO.

Tassinari, C. C. G., 1988. As idades das rochas e dos eventos metamórficos da porção Sudeste do Estado de São Paulo e sua evolução crustal. Dissertação de $\mathrm{PhD}$, Instituto de Geociências, Universidade de São Paulo, 236 pp.

Tassinari, C. C. G., Barbour, A.P., Daitx, E.C., Sato, K, 1990. Aplicações de isótopos de Pb e Sr na determinação da natureza das fontes das mineralizações de chumbo no Vale do Ribeira - SP e PR. In: Congresso Brasileiro Geologia, 36, Natal. Anais. SBG. v.3., 1254-1265

Tassinari, C.C.G., Munhá, M.U., Ribeiro, A., Correia, C.T., 2001. Neoproterozoic oceans in the Ribeira Belt (southeastern Brazil): the Pirapora do Bom Jesus ophiolitic complex. Episodes, 24(2): 245251.

Teixeira, AL., 1995. Ambientes geradores dos sedimentos da Bacia Eleutério. São Paulo. Dissertação de mestrado, Instituto de Geociências, Universidade de São Paulo, 132 pp.

Teixeira, A.L. Gaucher, C., Gomes, P.P.S., Marques, F.M., Vaz, P.C., Ferrerira, S.F.W., Rodrigues, A.A., 2004. Capítulo XXIX: Bacias do estágio da transição da plataforma Sul-Americana. Livro Geologia do Continente Sul-Americano: Evolução da Obra de Fernando Flávio Marques de Almeida. Mantesso-Neto, V., Bartorelli, A., Carneiro, C.D.R., Brito-Neves, B.B. Beca Produções Culturais Ltda.

Teixeira, A.L., Petri, S., 1993. Tectônica e sedimentação da Bacia Eleutério (Eopaleozóico?), Sudeste do Brasil. In: DINAMIGE-Fac. Agron., Simp. Intern. Del Neoproterozoico-Cambrico de la Cuenca del Plata, 1, La Paloma-Minas, Resumenes extensos, Tomo I, res. 17.

Teixeira, A.L., Petri, S., 2001. Estratigrafia e correlação da bacia de Pouso Alegre, transição Neoproterozóico-Cambriano, Minas Geras, Brasil. Revista do Instituto Geológico 22 (1/2), 5 26.

Teixeira, W. 1982. Interpretações e evolução geocronológica. In: Projeto RADAMBRASIL. Folha SG21. Assunción, SG-22, Curitiba e SG-23. Iguape. Considerações sobre os dados radiométricos. Rio de Janeiro, MME. (Relatório Interno). 
Theodorovicz, A.; Câmara, M.M., 1988. Ambiência tectônica da faixa Itaiacoca-Itapeva na região Sudeste do Estado de São Paulo. In: Congresso Brasileiro de Geologia, 35, Belém. Anais. Belém, SBG.

Theodorovicz, A.; Câmara, M.M.; Morais, S.M.; Godoy, H.K; Takahashi, A.T. 1986. Projeto Engenheiro Maia-Ribeirão Branco. Relatório Final. CPRM/PROMINÉRIO.

Theodorovicz A., Câmara, M. M., Takahashi, A. T., Morais, S. M., Godoy, H. K., 1988. Geologia do Pré-Cambriano das Folhas Engenheiro Maia e Ribeirão Branco, São Paulo. In: SBG, Congresso Brasileiro de Geologia, 35, Belém-PA. Anais. São Paulo, 2713-2726.

Toy, V.G., Prior, D.J., Norris, R.J., 2008. Quartz fabrics in the Alpine Fault mylonites: influence of preexisting preferred orientations on fabric development during progressive uplift. Journal of Structural Geology 30, 602-621.

Trein, E., Reis Neto, J.M., Biondi, J.C., Monastier, M.S., 1985. Revisão da Formação Itaiacoca: identificação de uma seqüência metavulcanossedimentar em Abapã (PR). V Simpósio Regional de Geologia, vol. 1. SBG, São Paulo, pp. 169-186.

Trepmann, C.A., Stöckhert, B., 2003. Quartz microstructures developed during non-steady state plastic flow at rapidly decaying stress and strain rate. Journal of Structural Geology 25, 2035-2051.

Tullis, J.A., 1971. Preferred Orientations in Experimentally Deformed Quartzites. Unpublished Ph.D. Thesis. University of California, Los Angeles.

Tullis, J., 2002. Deformation of granitic rocks: experimental studies and natural examples. Reviews in Mineralogy and Geochemistry 51, 51-95.

Tullis, J.A., Christie, J.M., Griggs, D.T., 1973. Microstructures and preferred orientations of experimentally deformed quartzites. Geol. Soc. Am. Bull. 84, 297-314.

Turner, F.J., Weiss, L.E., 1963. Structural Analysis of Metamorphic Tectonites. McGraw-Hill, New York.

Urai, J.L., Means, W.D., Lister, G.S., 1986. Dynamic recrystallization of minerals. In: Hobbs, B.E., Heard, H.C. (Eds.), Mineral and Rock Deformation: Laboratory Studies, Geophysical Monograph, vol. 36. American Geophysical Union, Washington DC, pp. 161-199.

Vieira, O.A.R.P., 2017. Geologia da Folha Guapiara 1:50000 (SG-22-X-B-II-2). Dissertação de Mestrado, Instituto de Geociências e Ciências Exatas, Universidade Estadual Paulista, 147 pp.

Vidal-Torrado, P., Calvo, R., Macias, F., Carvalho, S.G., Silva, A.C., 2007. Evolução geoquímica e mineralógica em perfis de alteração sobre rochas serpentinizadas no Sudoeste de Minas Gerais. Revista Bras. Ci. Solo 31, 1069-1083.

Wahlstrom, E.E., 1969. Cristalografia óptilca. (Tradução de Rui Ribeiro Franco) Ed. Universidade São Paulo, 368.

Weber, W.; Siga JR., O.; Sato, K.; Basei, M. A. S.; Reis Neto, J. M., 2003. U-Pb (zircon) ages of metabasic rocks of the Água Clara Formation in the Araçaíba region-SP-Brazil: preliminary data. In: South American Symposium on Isotopes Geology, 4. Salvador. Short Papers. Salvador: CBPM/IRD, v. 2, 706-709. 
Weber, W., Siga Jr., O., Sato, K., Reis Neto, J.M., Basei, M.A.S., Nutman, A.P., 2004. A Formacão Água Clara na Região de Araçaiba-SP: Registro U-Pb de uma Bacia Mesoproterozóica. Geologia USP-Série Científica 4., pp. 101-110.

Wilson, M., 2007. Igneous petrogenesis: a global tectonic approach. - London: Chapman \& Hall, xvii, $466 \mathrm{pp}$.

Winchester, J. A., Floyd, P. A., 1977. Geochemical discrimination of different magma series and their differentiation products using immobile elements. Chemical Geology 20, 32-343.

Zucali, M., Voltolini, M., Ouladdiaf, B., Mancini, L., Chateigner, D., 2014. The 3d quantitative lattice and shape preferred orientation of a mylonitised metagranite from Monte Rosa (Western Alps): Combining neutron diffraction texture analysis and synchrotron X-ray microtomography. Journal of Structural Geology 63, 91-105.

Zulauf, G., 2001. Structural style, deformation mechanisms and paleodifferential stress along an exposed crustal section: constraints on the rheology of quartzofeldspathic rocks at supra- and infrastructural levels (Bohemian Massif). Tectonophysics 332, 211-237. 
APPENDICES 